\title{
Risicomodellering veehouderij en gezondheid (RVG): modellering van regionale endotoxineconcentraties en relaties met gezondheidseffecten
}

Dick Heederik, Hans Erbrink, Azadeh Farokhi, Thomas Hagenaars, Gerard Hoek, Nico Ogink, Myrna de Rooij, Lidwien Smit, Albert Winkel, Inge Wouters

Utrecht, Wageningen, Arnhem, Lelystad; februari 2019

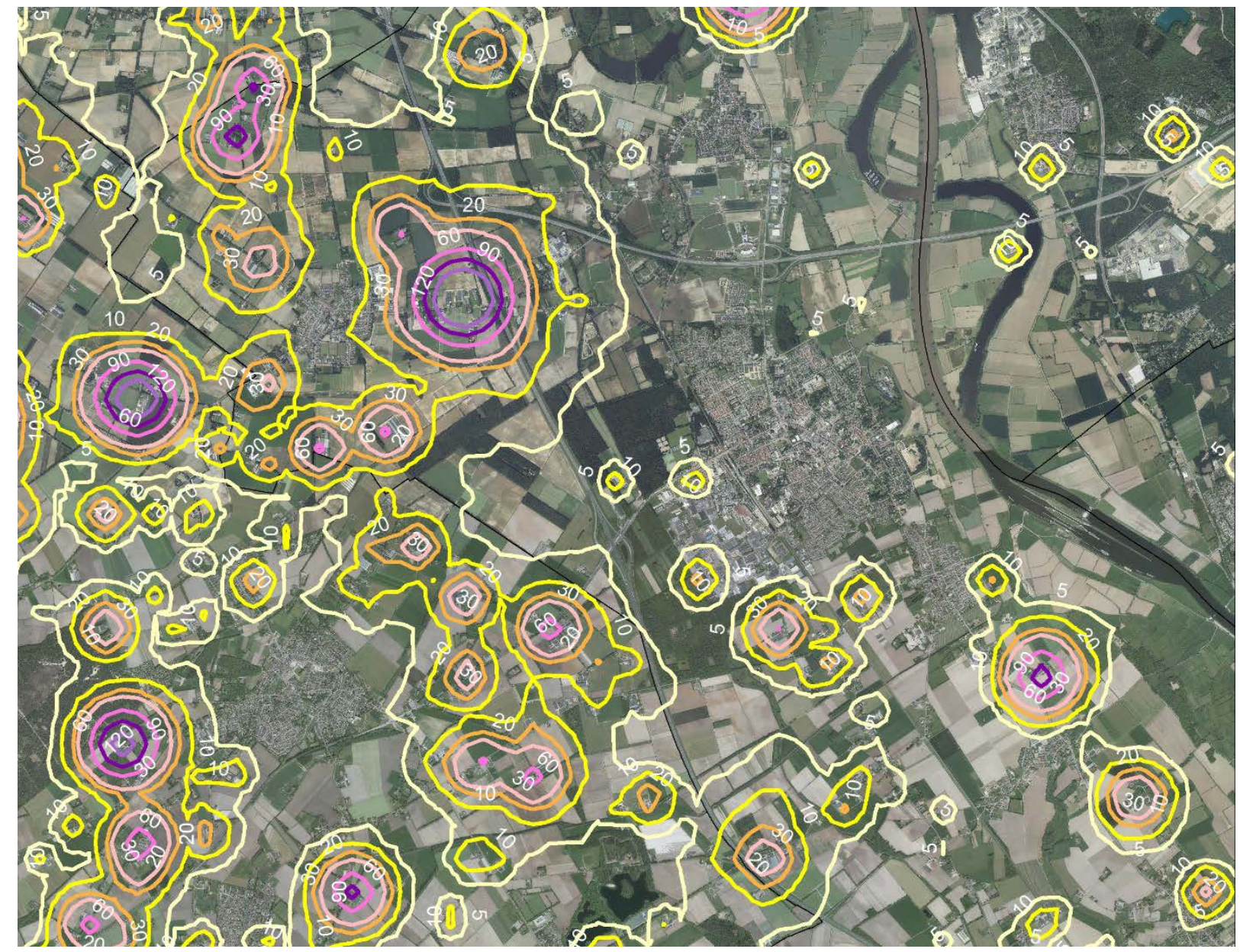

Rapport nummer: IRAS UU 2019-01 / WBVR-1910304

Digitaal beschikbaar op: https://doi.org/10.18174/470543

Institute for Risk Assessment Sciences, Universiteit Utrecht, Utrecht; Wageningen Bioveterinary Research, Lelystad en Wageningen Livestock Research, Wageningen; Erbrink Advies, Arnhem 


\section{INHOUDSOPGAVE}

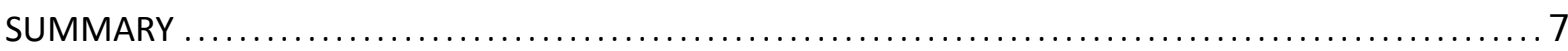

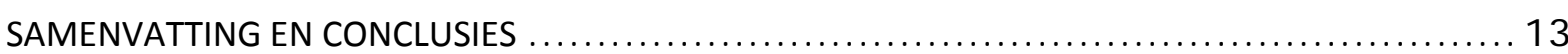

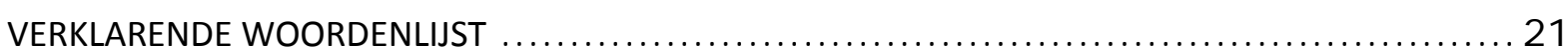

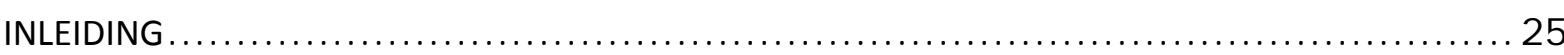

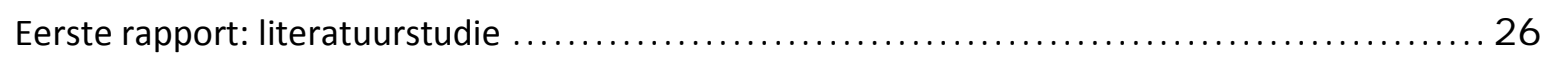

Tweede rapport: eerste emissiefactoren en verspreidingsmodel voor een puntbron ........... 26

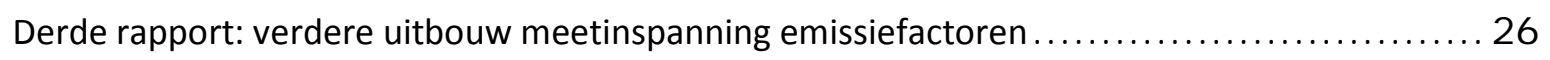

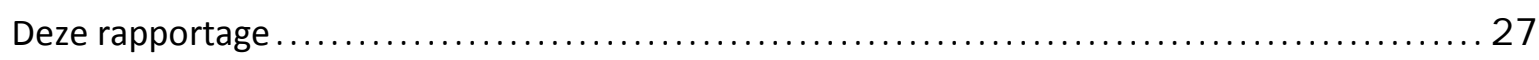

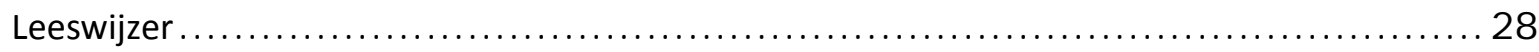

MODELLERING VAN ENDOTOXINECONCENTRATIES IN DE LEEFOMGEVING $\ldots \ldots \ldots \ldots \ldots \ldots \ldots \ldots \ldots \ldots \ldots \ldots \ldots$

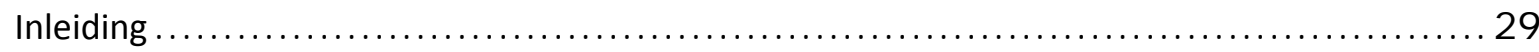

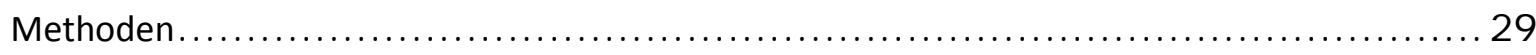

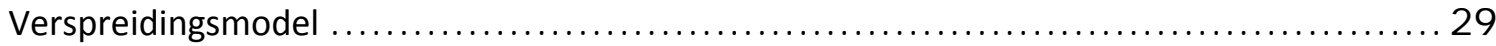

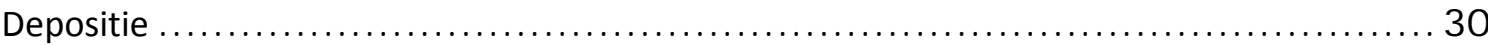

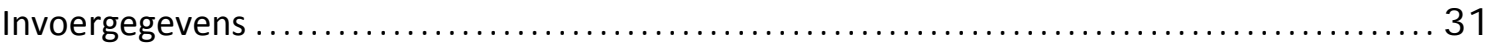

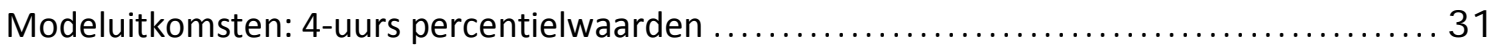

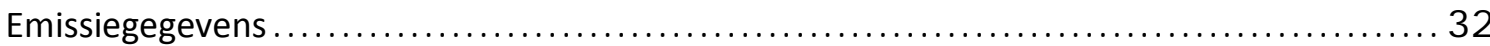

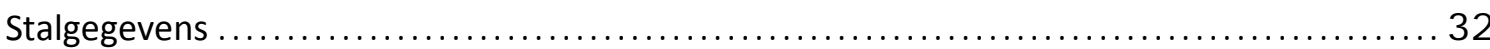

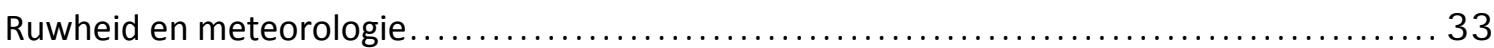

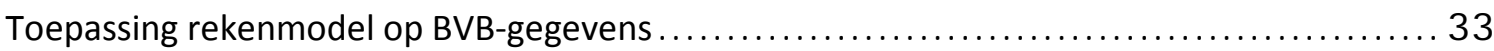

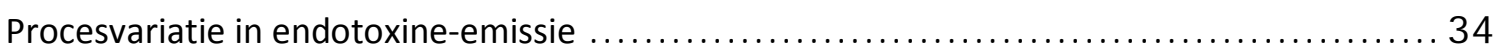

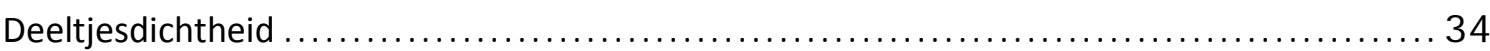

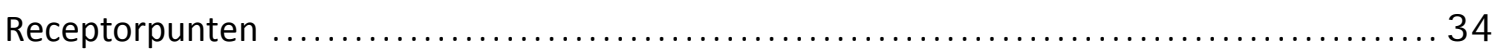

Presentatie endotoxineconcentratie op receptorpunten en middelingsduur $\ldots \ldots \ldots \ldots \ldots \ldots \ldots \ldots$

Validatie verspreidingsmodel berekende omgevingsconcentraties endotoxine............. 36

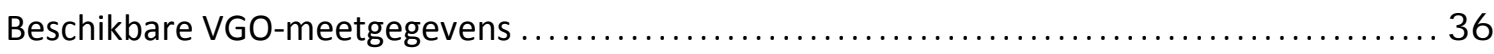

Vergelijkingen verspreidingsmodel met VGO LUR-model ......................... 36

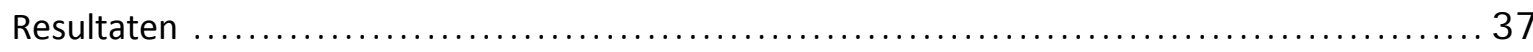

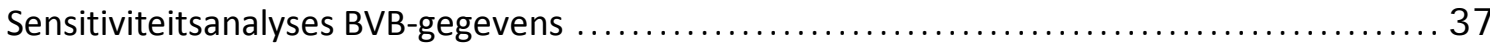

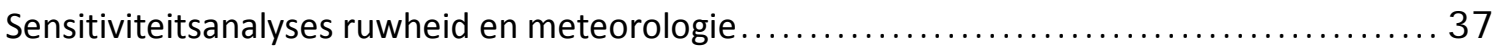

Sensitiviteitsanalyse voor het aantal bronnen rond een receptorpunt $\ldots \ldots \ldots \ldots \ldots \ldots \ldots \ldots \ldots$

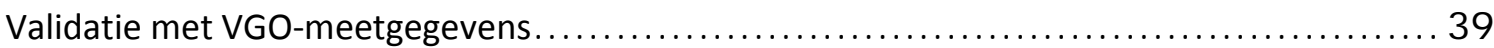

Vergelijkingen met LUR-model berekende endotoxine concentraties .................... 42

Hybride modellen $\ldots \ldots \ldots \ldots \ldots \ldots \ldots \ldots \ldots \ldots \ldots \ldots \ldots \ldots \ldots \ldots \ldots \ldots \ldots \ldots \ldots \ldots \ldots \ldots \ldots \ldots, 43$ 
Regionale endotoxine concentraties; niveaus en ruimtelijke verdeling ....

Conclusies

LITERATUURONDERZOEK NAAR EFFECTEN VAN ENDOTOXINEN BIJ LAGE CONCENTRATIES 55

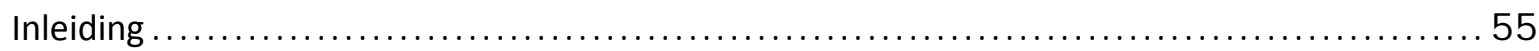

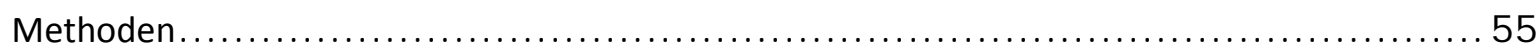

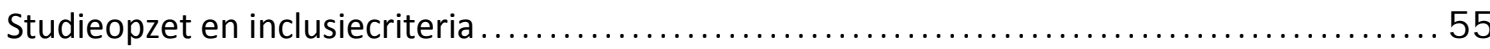

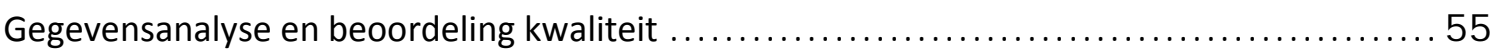

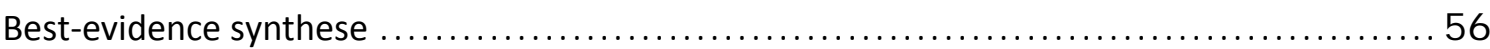

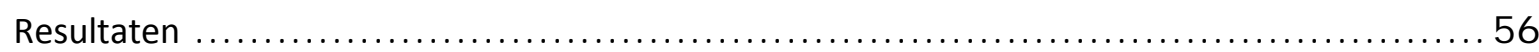

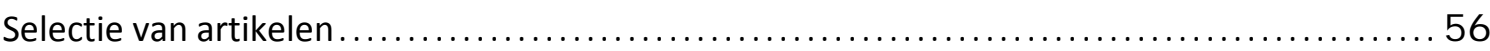

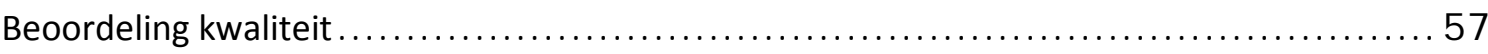

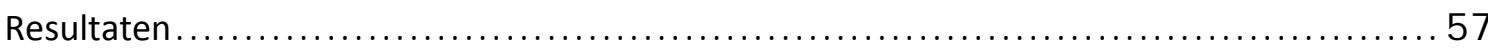

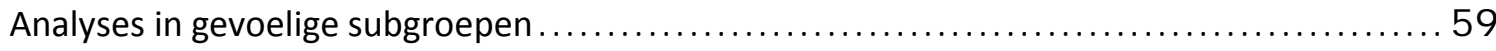

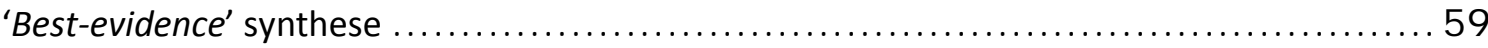

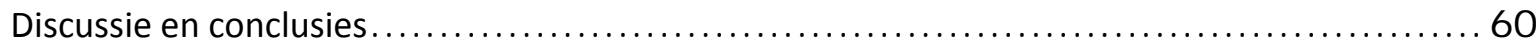

VGO STUDIE: HERANALYSE RELATIES MET GEZONDHEIDSEFFECTEN $\ldots \ldots \ldots \ldots \ldots \ldots \ldots \ldots \ldots 63$

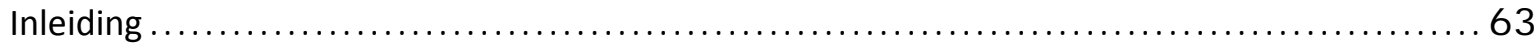

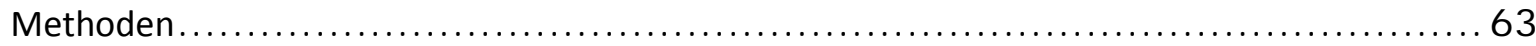

Globale informatie over de VGO-studie en gebruikte gezondheidseindpunten $\ldots \ldots \ldots \ldots \ldots \ldots 3$

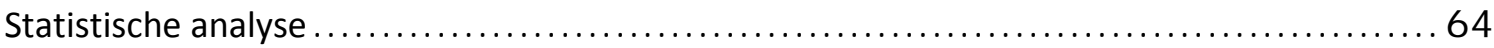

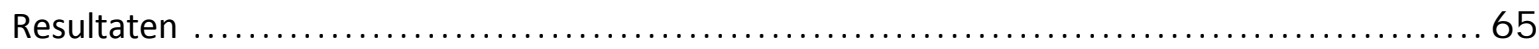

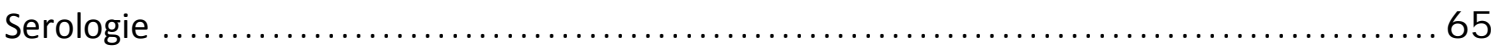

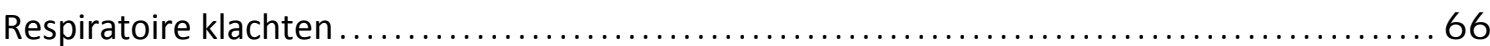

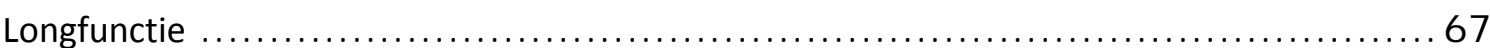

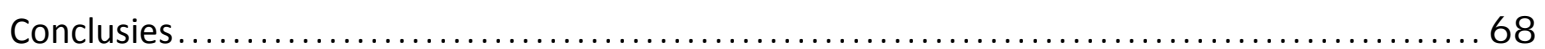

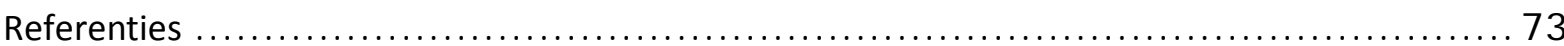

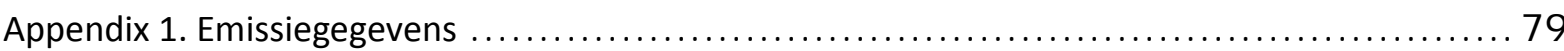

Tabel A.1.1. Basistabel emissie kenmerken ten behoeve van endotoxine modellering.......... 79

Tabel A1.2. Relatieve massabijdrage van de verschillende deeltjesfracties aan de $\mathrm{PM}_{100}$ massa naar

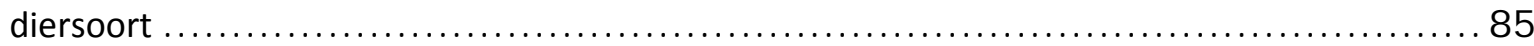

Tabel A.1.3. Endotoxinegehalte van stof voor de verschillende deeltjesfractie naar diersoort ... 85

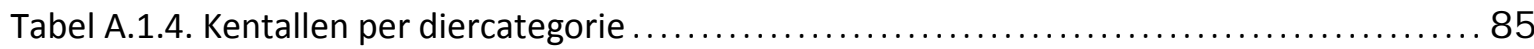

Figuur A1.1. Fit van deeltjesgrootteverdeling en endotoxinegehaltes voor geiten en paarden ... 86

Appendix 2a. Validatie RVG ten opzichte van VGO-omgevingsmetingen $\ldots \ldots \ldots \ldots \ldots \ldots \ldots \ldots 7$

Appendix 2 b. Relatieve bijdrage diersectoren aan omgevingsendotoxineconcentraties .......... 87 
Appendix 3. Artikel respiratoire effecten lage endotoxine concentraties

Appendix 4. Bijlage bij hoofdstuk 'effecten endotoxine bij lage concentraties' en Appendix 3. ... 109

Tabel A4.1. Pubmed zoekstrategie 109

Tabel A4.2. Studie incentives en andere blootstellingsvariabelen geassocieerd met de uitkomstvariabelen.

Tabel A4.3. Quality Assessment van geïncludeerde studies gebaseerd op het 'NIH Quality Assessment Tool for Observational Cohort and Cross-Sectional Studies' $\ldots \ldots \ldots \ldots \ldots \ldots \ldots \ldots \ldots \ldots \ldots \ldots$

Tabel A4.4. Overzicht van de resultaten - vragenlijstuitkomsten ....................... 115

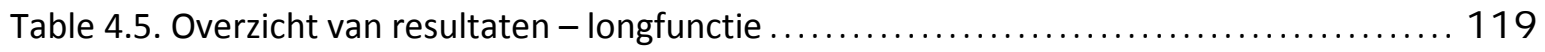

Tabel A4.6. Overzicht van resultaten - exposure-response relaties endotoxine $\ldots \ldots \ldots \ldots \ldots 123$

Tabel A4.6 Analyse van effecten van endotoxine blootstelling in specifieke subgroepen ...... 127

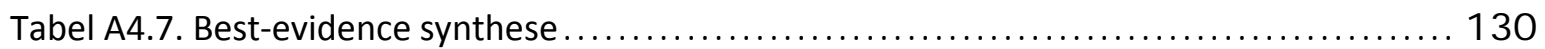

Appendix 5. Analyse associaties endotoxine op woonadres en gezondheidseffecten $\ldots \ldots \ldots \ldots \ldots 132$

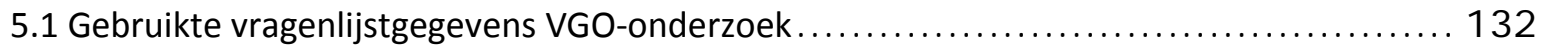

5.2 Fit voor verschillende blootstelling-responsmodellen. ............................ 133 


\section{SUMMARY}

This report describes results of a research project which aimed at exploring the importance of environmental endotoxin exposure resulting from emissions from livestock production farms and potential resulting health effects. As part of this project, environmental endotoxin concentrations were modelled and these concentrations were associated to health effects. The modeling part of the project consisted of the following elements:

- Regional endotoxin concentrations were modelled using dispersion models for a livestock dense area in the south of the Netherlands;

- 4-hour endotoxin levels were calculated at different coordinates over a period of a year and exceedance of a tentative exposure standard of 30 Endotoxin Units $/ \mathrm{m}^{3}$, proposed by the Netherlands Health Council, was evaluated.

- Contribution of particle size classes and animal categories to endotoxin concentrations were assessed. Maps of modelled endotoxin concentrations were produced to evaluate spatial variation.

- Modelled endotoxin concentrations were validated with endotoxin measurements in $\mathrm{PM}_{10}$ mass fraction, which were available from an earlier project for 61 locations in the same area, and allowed calculation of measured endotoxin concentrations over a period of a year.

The health effect part of the project consisted of the following elements:

- A literature survey was completed which aimed at evaluating respiratory health effects of endotoxin exposure at low levels of exposure (<100 Endotoxin Units $\left./ \mathrm{m}^{3}\right)$.

- Exposure-response-relations were explored between modelled annual average PM10 and endotoxin concentrations in ambient air and health effects (lung function, respiratory symptoms, atopic sensitization) as collected earlier in a large health effect study conducted in the same area (a study described with the acronym 'VGO-study').

Results of this study contribute to a better understanding of the potential public health relevance of environmental (airborne) endotoxin exposure from livestock emissions.

\section{Dust and Endotoxin modeling}

Modeling was performed using an extended version of STACKS which implements the so called 'Netherlands New National model'. Input consisted of dust emission data (dust per animal per year), information on the endotoxin content of the emitted dust obtained through a series of emission measurements collected in earlier projects and this project, meteorological data, information on terrain roughness, and provincial license data for livestock farms which gives information about the location of stables, some stable characteristics and the number of animals. Modeling resulted in annual average and 4-hour (percentile) endotoxin levels in $\mathrm{PM}_{100}$ mass fraction and $\mathrm{PM}_{10}$ mass fraction on different receptor points. Receptor points considered were a grid of 310000 points for a $70 \times 70 \mathrm{~km}^{2}$ area in the south of the Netherlands (parts of Noord-Brabant and Limburg), 61 locations where airborne dust sampling was conducted over a period of a year and home addresses of participants of a health survey (approximately 14000 addresses). Estimation of (annual average) endotoxin concentrations for 61 measurement locations facilitated the validation study in which modelled and measured annual endotoxin concentrations in ambient air were compared. Endotoxin estimation for the 14000 home addresses facilitated exposure response modeling for a range of health endpoints available from an earlier study ('VGO study'). 


\section{Sensitivity analyses and validation of model outcomes}

Sensitivity analyses showed that when 70 livestock farms around a receptor point were included, then endotoxin estimates were sufficiently precise as compared to including all livestock farms $(>8000)$ in the $70 \times 70 \mathrm{~km}^{2}$ study area. Therefore, calculations were limited to 70 sources around a receptor point to increase efficiency. Using area surface roughness information for a $2 \times 2 \mathrm{~km}^{2}$ area instead of a $5 \times 5 \mathrm{~km}^{2}$ area resulted in a decrease of $7 \%$ in endotoxin concentrations. For $70 \%$ of the receptor points the effect was smaller than $10 \%$. A change in the period for the meteorological data led to a maximum variation in the endotoxin concentration of $10 \%$. The changes in estimated concentrations were considered relatively small compared to uncertainties and variations in other input data such as emission data and the endotoxin content of the dust for the different animal species.

Validation of modelled annual average endotoxin concentrations with measured concentrations at the 61 measurement sites, showed a relatively good agreement when dispersion models were used that included plume elevation, which occurs as a result of the energy content of emitted air. When modelling was performed without including plume elevation, endotoxin concentrations in ambient air were over-estimated by a factor of on average approximately 2.5 .

As part of the VGO-study, environmental endotoxin levels were modeled using so called 'Land-Use Regression (LUR)' models. These models describe statistical associations between land use (presence of livestock production farms) and measured endotoxin concentrations. There is a good agreement between predictions of endotoxin concentrations obtained by dispersion modelling and those obtained by LUR modelling. Both models explain a similar proportion of variance in measured endotoxin concentrations.

The validation study also gives indications that modeled and measured endotoxin concentrations can differ considerably at specific receptor points, although on average these models agree with measurement results from the VGO-study. Several factors might contribute to the observed differences:

- Emission factors for endotoxin are based on a limited number of measurements and in some cases were extrapolated or obtained from air measurements in stables from the literature. As a result, the precision of these emission factors is limited.

- Emission factors describe the average emission per animal. It is known that the emission can vary considerably between livestock farms, probably resulting from differences in characteristics of livestock farms and farm management. There is not an appropriate approach available, apart from extensive measurement series, to control for these differences in farm emission.

- Emission information has been applied on license data. The number of animals present on a farm can differ from the licensed number of animals.

- Dispersion models do consider stable characteristics and presence of emission control technology to some extent. Recent results from a study on the efficacy of specific control technology in pig production and experiences with use of the control measures in practice, show that assumptions regarding the effect of these exposure controls on emission are not always correct.

- Uncertainties resulting from factors not accounted for in the dispersion model (presence of buildings and local vegetation (trees)).

This results in imprecision, uncertainty and estimation errors that can lead to biased model predictions for all or certain individual receptor points. 
So called hybrid models, models that combine dispersion modelling with LUR modelling, were explored, but these did not lead to substantial improvements.

\section{Endotoxin concentrations at receptor points}

Variation in modelled endotoxin concentrations for the VGO-study area was considerable. The proportion of receptor points with a 99,5\% percentile endotoxin concentration over 4 hours above 30 Endotoxin Units $/ \mathrm{m}^{3}$ (thus exceedance of $30 \mathrm{EU} / \mathrm{m}^{3}$ in $0,5 \%$ of the time) is $1.8 \%$. Particles of all sizes contribute to these endotoxin concentrations at a receptor point but the variation in contribution is large and depends on the animal species present near receptor points and distance from stables of receptor points. Several 'hot spots' were observed with elevated airborne endotoxin concentrations in areas with a high livestock production density. All animal species contribute to the modelled endotoxin concentrations, but the contribution varies strongly. In particular, relatively rare animal species that do not contribute to the overall endotoxin exposure, can locally have relevant and specific contribution patterns. It is important to note that for most receptor points the endotoxin concentration has many contributing species. This implies that reduction of airborne concentrations can be realized only to a limited extent by focusing on emission reduction measures for one particular animal species.

\section{Health effects of endotoxin at low levels of exposure}

There is clear evidence that occupational exposure to high concentrations of airborne endotoxin causes respiratory inflammation, respiratory symptoms and lung function decline. However, health effects of exposure to low levels of endotoxin are less well described. A systematic review was conducted to summarize published associations between exposure to relatively low levels of airborne endotoxin and respiratory health endpoints. In total, 1362 articles were identified through a PUBMED database search, of which 31 articles met the pre-defined inclusion criteria and were included in the review. Respiratory health effects of exposure to low levels of airborne endotoxin $(<100 \mathrm{EU} / \mathrm{m} 3)$ seem plausible. Future studies are needed to further investigate lower levels of exposure to endotoxin as observed in ambient air and potential respiratory health effects, especially in vulnerable subgroups of the population.

\section{Respiratory effects in relation to environmental endotoxin levels}

Re-analysis of the VGO-study results for atopy (sensitization to a range of environmental allergens), respiratory symptoms and lung function measured by spirometry with modelled environmental PM10 and endotoxin concentrations at the home address of the study participants resulted in several statistically significant associations between modelled PM10, but in particular modelled endotoxin concentration and health endpoints. Earlier analyses were based on associating the health endpoints with livestock density around the home address or the distance from the nearest livestock farm.

Of the 12 variables explored earlier in the VGO study (atopy (sensitization to at least one allergen out of a panel of environmental allergens or elevated total IgE-level) (1), lung function (4), and respiratory disease/symptoms (7)); 6 were most strongly associated with endotoxin exposure, based on model fit, 4 with farm density around the home address and 1 with distance to the nearest farm, and one with PM10 exposure. Briefly, the following associations were found:

- A strong and statistically significant association is observed between atopic status and endotoxin concentration. This analysis confirms earlier observed protective effects in neighboring residents of livestock farms, but now in relation to modelled airborne endotoxin concentrations at the home address. 
- Respiratory symptoms that were associated with density of livestock farming around the home address (but not with distance from the nearest farm), such as wheezing, wheezing with shortness of breath and wheezing in absence of a cold, were generally also associated with modelled airborne endotoxin concentrations at the home address. Stronger associations were identified with modelled airborne endotoxin concentrations compared to density of livestock farming for the outcomes wheezing and wheezing with shortness of breath. The shape of the association between endotoxin and wheezing was characterized by an initial decline in prevalence and and increase in symptom prevalence at higher environmental endotoxin levels.

- Associations with lung function were, just like with distance from the nearest farm or farm density, relatively weak. The direction of the exposure response relations was generally comparable with the direction for the exposure proxy of farm density. The shape indicated a more gradual increase in risk for endotoxin exposure, which may be indicative of effects of exposure misclassification in the analysis with the exposure proxy (farm density). No statistically significant associations were observed for PM10 exposure.

PM10 and endotoxin concentrations at a certain receptor point are determined by several variables, among which the number of livestock farms, distance to livestock farms, the type and size of farm (number of animals), roughness of the surface area. LUR and dispersion modeling take these variables into account, to a varying extent. In addition, dispersion models also consider environmental characteristics (e.g. terrain roughness, meteorological data). Earlier analysis of the VGO study made use of simple proxy exposure variables such as distance from the nearest farm and farm density around the home address. This explains the environmental endotoxin exposure only to a limited extent. This should be kept in mind when interpreting present results in comparison to earlier findings of the VGO study.

In summary, similar and often stronger spatial associations have been observed for environmental endotoxin levels at the home address and atopy and respiratory health effects. In particular the strong association with atopy is remarkable. The fact that associations were more often stronger in terms of model fit for endotoxin in comparison with PM10 supports the hypothesis that endotoxin is a relevant markers of livestock related exposure, predictive of health effects. The fact that a microbial marker is directly associated with health effects, and is more strongly associated with these health effects than PM10 levels, marks the specific nature of primary emitted dust from livestock farms. Endotoxins are not emitted by traffic and most industries.

\section{General conclusions and recommendations}

This study gives a first insight into endotoxin concentrations in ambient air that result from emissions from livestock production farms. Results show that the tentative exposure limit of 30 Endotoxin Units $/ \mathrm{m}^{3}$, proposed by the Netherlands Health Council, can be exceeded during 4-hours periods, but during a relatively short time span over a year. The endotoxin concentration at a certain receptor point is determined by the presence of livestock farms. Different types of livestock farming contribute to endotoxin concentrations in ambient air. Not one specific type of livestock farming contributes most at all of the receptor points. The contribution at a certain location is determined by the animal species, farm type, the number of animals and number of farms in an area. As a result, the contribution of different animal species can vary considerably from area to area. Consequently, potential reduction of endotoxin concentrations in ambient air is determined by several factors, and, in particular, the combination of animal species, farm size, farm type and number of farms determine the endotoxin concentration at a certain location. 
In conclusion, we generally found similar and, based on model fit, regularly stronger associations between modelled airborne endotoxin concentrations at the home address with health endpoints, as observed in the VGO-study with distance from the nearest farm or farm density. The excess risk of pneumonia in the study area, one of the consistent findings of the VGO-study, was not explored in this report. We recommend that associations between the occurrence of pneumonia and airborne endotoxin concentrations should be studied using the endotoxin modelling information from this project in particular because endotoxin seems a clear predictor of health risks studied in this report.

This study was performed as part of a series of studies aimed at exploring whether a legal framework should be developed for endotoxin exposure concentrations in ambient air resulting from livestock farms as it exists for odor nuisance and fine particulate matter. The question is whether results from this study justify development of a legal framework for evaluation of endotoxin exposure in ambient air. The answer to this question is beyond the scope of this project. However, it is important to consider that endotoxin seems a relevant marker of health risks. Risk assessment based on environmental PM10 exposure resulting from livestock farms should take into account the endotoxin content of PM10 dust. The toxicological properties of endotoxin containing farm related PM10 is likely to differ from PM10 from industrial sources or from traffic.

In addition, the models developed as part of this project can give insight into effects resulting from developments in livestock production such as further aggregation of farms, changes in the numbers of animals, and emission reduction at the level of livestock production farms resulting from technological developments, or policy decisions and agreements. In that sense, results from this study will certainly find application, in the near future, and contribute to the discussion on livestock production and public health. 


\section{SAMENVATTING EN CONCLUSIES}

Dit onderzoeksproject richt zich op de beoordeling van de betekenis van het voorstel van de Gezondheidsraad voor een grenswaarde voor endotoxine van 30 Endotoxine Units (EU)/ $/ \mathrm{m}^{3}$ voor de algemene bevolking, in het bijzonder voor omwonenden van veehouderijbedrijven. De doelstellingen van het project zijn:

- Ontwikkelen van een regionaal (model)instrument waarmee de heersende blootstelling aan endotoxine in de omgevingslucht als gevolg van emissies van veehouderijen in een onderzoeksgebied kan worden onderzocht. Als voorbeeld is hiervoor het VGO onderzoeksgebied genomen. Het instrument moet ook geschikt zijn om het effect van nieuwvestigingen en emissie-reducerende maatregelen op de blootstelling van omwonenden te berekenen.

- Onderzoeken met behulp van dit instrument:

o Wat de heersende blootstelling aan endotoxine in de omgevingslucht is als gevolg van emissies van veehouderijen en onderzoeken in welke mate de tentatieve grenswaarde voor endotoxine overschreden wordt op woonlocaties.

o Welke relaties er zijn tussen endotoxineblootstelling en eerder in het VGO onderzoek gemeten gezondheidseffecten bij omwonenden en wat de omvang is op populatieniveau van de effecten gerelateerd aan endotoxineblootstelling.

Het project bestond uit twee hoofdonderdelen, modellering van endotoxineconcentraties in de lucht voor een groot gebied op basis van emissiegegevens en onderzoek naar gezondheidseffecten door endotoxine. Het modelleringsdeel van het project bestond uit de volgende onderdelen:

- Ontwikkeling van het modelinstrument in de vorm van pluimmodellering van de endotoxineconcentratie in een groter gebied op leefniveau (VGO-onderzoeksgebied in Noord-Brabant en Limburg). Hierin wordt voor de beschrijving van de bronemissie gebruik gemaakt van gegevens die afgelopen jaren verzameld zijn in een reeks projecten waarin de endotoxine-emissie is gekwantificeerd voor meerdere diersoorten en bedrijfstypen;

- Berekening van 4-uurs endotoxineconcentraties in het gehele gebied dat in de VGO-studie is onderzocht (oostelijk deel Noord-Brabant en noorden van Limburg). Dit geeft een beeld van de locaties waar regelmatig overschrijding van de door de Gezondheidsraad voorgestelde grenswaarde van $30 \mathrm{EU} / \mathrm{m}^{3}$ plaatsvindt;

- De bijdrage van deeltjesgrootte klassen en diercategorieën aan de endotoxine concentraties is bepaald. De ruimtelijke variatie in gemodelleerde endotoxine concentraties is onderzocht door middel van kaarten.

- Validatie van de gemodelleerde endotoxineconcentraties met omgevingsmetingen die in het kader van de VGO-studie zijn verzameld voor 61 meetlocaties gedurende een periode van anderhalf jaar.

Het onderzoek naar gezondheidseffecten van endotoxine bestond uit de volgende onderdelen:

- Systematisch literatuuronderzoek naar effecten van endotoxine op de luchtwegen bij lage concentraties endotoxine;

- Analyse van blootstelling-responsrelaties door de gemodelleerde jaargemiddelde PM10 en endotoxineconcentratie in de lucht op het woonadres te koppelen aan gezondheidsgegevens die verzameld zijn in het medisch onderzoek van de VGO-studie (respiratoire symptomen, longfunctie, allergische sensibilisatie). Deze analyses met 
gemodelleerde concentraties PM10 en endotoxine op het woonadres vormen een aanvulling op eerdere analyses met simpele proxies voor veehouderij gerelateerde blootstelling waaronder afstand tot veehouderijbedrijven en dichtheid van veehouderijbedrijven rond het woonadres. Indien relaties worden aangetoond tussen endotoxine-emissies en gezondheidseffecten bestaat de mogelijkheid de bijdrage van endotoxine aan het voorkomen van de gezondheidseffecten te onderzoeken.

De resultaten van dit onderzoek dragen bij aan een antwoord op de vraag of het huidige toetsingskader voor emissies van veehouderijbedrijven, dat gebaseerd is op beoordeling van geuren fijnstofemissies, moet worden uitgebreid met een toetsing op endotoxineconcentraties in de omgeving. Dit onderzoek maakt gebruik van eerder uitgevoerde deelonderzoeken die gericht waren op het vaststellen van de emissie aan stof en endotoxine door veehouderijen. In dit rapport zijn alle emissiemetingen samengevoegd, zijn aanvullende emissiemetingen beschreven en is door extrapolatie en door gebruik te maken van literatuurgegevens voor alle typen veehouderijbedrijven en diersoorten een emissiefactor vastgesteld. Met deze informatie kan voor een groot gebied waarin zich verschillende diersoorten en typen veehouderijbedrijven bevinden het effect van emissie van stof en endotoxine op de concentraties stof en endotoxine in de lucht worden onderzocht.

\section{Stof en endotoxinemodellering}

De modellering van endotoxinen bestaat uit een aantal onderdelen: het rekenmodel, de invoer van het rekenmodel, en de toepassing van het rekenmodel op stallen. Het rekenmodel is een uitgebreide versie van het model STACKS. De berekeningen zijn uitgevoerd conform het 'Nieuw Nationaal Model (NNM)' én de 'Aanvullende afspraken NNM' zoals beschreven in de 'Standaardrekenmethode 3 (SRM3)' met uitbreidingen voor pluimdaling en als gevolg daarvan een proportioneel groter massaverlies voor grotere deeltjes. De invoer van het model bestaat uit stofemissiegegevens voor stallen aangevuld met informatie over het gehalte aan endotoxinen in het geëmitteerde stof.

In eerder onderzoek is door uitvoering van luchtmetingen in stallen stof verzameld, waarin het endotoxinegehalte is bepaald. Dat is gedaan in 4 stoffracties: $\mathrm{PM}_{2,5}, \mathrm{PM}_{30}$ (deel van de metingen), $\mathrm{PM}_{10}$ en $\mathrm{PM}_{100}$. Door een gedetailleerde gegevensanalyse zijn de meetresultaten omgerekend naar 10 stoffracties met elk een bepaald endotoxinegehalte. Van de stallen in het onderzoeksgebied zijn gegevens over de locatie en stal- en emissiehoogte gebruikt. Ook zijn terrein- en meteorologische gegevens gebruikt. Voor een groot aantal stallen zijn de stalgegevens verkregen uit het Bestand Veehouderij Bedrijven (BVB, vergunningengegevens): diersoort, aantal dieren, locatie, $\mathrm{PM}_{10}$ emissie per dier. Per diersoort zijn generieke $\mathrm{PM}_{100} / \mathrm{PM}_{10}$ ratio's toegevoegd, zodat de $\mathrm{PM}_{100}$ ('total suspended particles', 'TSP') emissie is geschat. Deze PM100 emissie is opgedeeld in 10 stofdeeltjesfracties. Deze worden met STACKS doorgerekend (per stal) en op een groot aantal receptorpunten in het onderzoeksgebied wordt de gezamenlijke invloed van alle omliggende stallen berekend.

Er zijn voor de verschillende doelstellingen verschillende receptorpunten gebruikt:

- een vast raster van 310000 punten voor een gebied van $70 \times 70 \mathrm{~km}^{2}$ waarmee endotoxinekaarten konden worden gemaakt voor dit gebied;

- de coördinaten van 61 meetlocaties op leefniveau die in het kader van het VGO-onderzoek zijn uitgevoerd zodat gemodelleerde en gemeten endotoxineconcentraties in de omgeving konden worden vergeleken;

- de woonadressen van deelnemers aan het VGO-gezondheidsonderzoek zodat de relatie gemodelleerde endotoxineconcentraties op het woonadres en gezondheidseffecten met gegevens afkomstig van de VGO-studie konden worden geanalyseerd. 
De uitvoer bestaat uit jaargemiddelde endotoxineconcentraties en uurgemiddelde endotoxineconcentraties waarmee 4-uurs gemiddelde endotoxineconcentraties zijn berekend. Resultaten zijn ook uitgedrukt in percentielen over de periode van een jaar op de verschillende receptorpunten.

\section{Sensitiviteitsanalyses en validatie van uitkomsten rekenmodel}

Onderzocht is of het voor een receptorpunt nodig was alle bronnen in het onderzoeksgebied van $70 \times 70 \mathrm{~km}^{2}$ mee te nemen. Uit een sensitiviteitsanalyse bleek dat 70 bronnen per receptorpunt voldoende was om tot precieze schattingen van de endotoxineconcentratie te komen zodat berekeningen kosten-effectiever konden worden uitgevoerd.

Ook is een sensitiviteitsanalyse uitgevoerd voor ruwheidsparameters (voor een $2 \times 2 \mathrm{~km}^{2}$ gebied in plaats van een $5 \times 5 \mathrm{~km}^{2}$ gebied) om het effect van een verfijning van de ruwheidsinformatie te kwantificeren. Dit leidde tot gemiddeld een $7 \%$ lagere endotoxineconcentratie. Bij $70 \%$ van de receptorpunten was het effect kleiner dan 10\%. De keuze voor een bepaalde periode voor de meteorologiegegevens leidde tot variaties in de berekende concentraties van maximaal $10 \%$. Dergelijke veranderingen in uitkomsten kunnen als relatief gering beschouwd worden in verhouding tot onzekerheden in andere aspecten zoals de emissiegegevens en het endotoxinegehalte van het stof en de variatie daarin.

De validatiestudie, die bestaat uit het vergelijken van berekende endotoxineconcentraties met metingen op 61 locaties, laat zien dat modelberekeningen en metingen goed overeenkomen als een model wordt gebruikt dat uitgaat van warmte-emissies (pluimstijging door emissie van warme lucht na het verlaten van de stal). Als warmte-emissies niet worden meegenomen dan worden de jaargemiddelde endotoxineconcentraties op de 61 meetlocaties ongeveer met een factor 2,5 overschat. Overigens wordt in de huidige modellen voor geur- en stofemissies de warmte-emissie niet meegenomen zoals in deze studie wel is gedaan.

Als de warmte-emissie in de verspreidingsmodellering wordt meegenomen is de overeenkomst tussen de endotoxineconcentraties verkregen met het verspreidingsmodel en het LUR-model over het algemeen goed. De mate van variatie verklaard door het verspreidingsmodel is vergelijkbaar met de mate van variatie verklaard door het LUR-model. De validatiestudie geeft ook aanwijzingen dat op specifieke locaties de verschillen tussen gemodelleerde en gemeten concentraties aanzienlijk kunnen zijn. Een deel van deze verschillen is toe te schrijven aan de benaderende beschrijving van het verspreidingsproces door het model. Daarnaast kunnen onzekerheden in de volgende invoerfactoren hieraan ten grondslag liggen:

- Emissiefactoren voor endotoxine zijn afgeleid van stofemissiefactoren en gebaseerd op beperkte aantallen metingen en in sommige gevallen op extrapolaties of informatie afkomstig uit de literatuur. De emissiefactoren zijn daardoor onvermijdelijk beperkt in nauwkeurigheid.

- Emissiefactoren beschrijven de gemiddelde emissie per dier in een stalcategorie. Bekend is dat de emissie voor individuele bedrijven binnen een categorie aanzienlijk kan afwijken van deze gemiddelde emissie, vermoedelijk als gevolg van verschillen in structurele kenmerken van de bedrijven en bedrijfsvoering en management. Er is geen geschikte manier om deze variatie in emissie mee te nemen in de modellen zonder uitgebreide meetinspanningen op bedrijfsniveau.

- De emissiegegevens zijn toegepast op de vergunde dieraantallen. Op bedrijven kunnen de dieraantallen afwijken van de vergunde aantallen .

- In de verspreidingsmodellen wordt rekening gehouden met stalkenmerken en de aanwezigheid van emissiereductiemaatregelen. Recente resultaten van onderzoek naar de 
effectiviteit van luchtwasinstallaties in de varkenshouderij voor geur en ammoniak (die overigens niet zondermeer naar stofdeeltjes te extrapoleren zijn) en ervaringen met het gebruik van deze maatregelen in de praktijk laten zien dat de gebruikte veronderstellingen in de verspreidingsmodellen niet altijd juist hoeven te zijn.

- Daarnaast zijn er nog andere onzekerheden in de modellering zoals de rol van bebouwing en begroeiing waar geen rekening mee wordt gehouden.

De uit deze factoren voortvloeiende onnauwkeurigheden, onzekerheden en inschattingsfouten kunnen ertoe leiden dat modelvoorspellingen op specifieke locaties niet juist zijn.

Ook is een verkenning uitgevoerd of hybride modellen, waarbij verspreidingsmodellen en LURmodellen gecombineerd worden, tot betere voorspellingen van de gemeten endotoxineconcentraties zouden leiden. Gebleken is dat hybride modellen niet tot een substantiële verbetering in de nauwkeurigheid van voorspelde endotoxineconcentraties leiden.

\section{Gebiedsmodellering}

De modelberekeningen voor het VGO-gebied laten een aanzienlijke ruimtelijke variatie in endotoxineconcentratie zien. Het aantal punten met een 99,5\% percentielwaarde hoger dan 30 $\mathrm{EU} / \mathrm{m}^{3}$ (dus $30 \mathrm{EU} / \mathrm{m}^{3}$ wordt in $0,5 \%$ van de tijd overschreden) is $1,8 \%$. Deeltjes van alle groottes dragen bij aan de endotoxineconcentratie op een receptorpunt maar de variatie in de bijdrage is groot en hangt af van de combinatie van diersoort, aantallen bedrijven en dichtheid van de aantallen bedrijven en afstand tot een receptorpunt (woning). Er zijn meerdere 'hotspots' met zeer lokaal verhoogde concentraties endotoxine op locaties met een hoge dichtheid aan veehouderijbedrijven. Alle diersoorten dragen bij aan de concentratie endotoxine op de verschillende receptorpunten, maar de bijdrage varieert sterk en kan van 'hotspot' tot 'hotspot' variëren. Enkele diersectoren met maar een beperkt aantal bedrijven in de onderzochte regio kunnen op zeer lokaal niveau een markant bijdrage-patroon hebben (kalkoenen, konijnen), met alleen, op een paar locaties, een duidelijke bijdrage aan de endotoxineconcentratie. In het algemeen geldt dat de endotoxineconcentratie op de meeste locaties veel determinanten kent. In principe dragen alle diersoorten bij aan de endotoxine concentratie. Dit impliceert dat reductie van concentraties in de omgevingslucht maar beperkt realiseerbaar is door emissie-reducerende maatregelen die zich tot één enkele diersector of diersoort beperken.

\section{Gezondheidseffecten literatuurstudie}

Endotoxinen leiden tot respiratoire effecten op de gezondheid (luchtwegklachten, acute en chronische longfunctieveranderingen, ontstekingsreacties). Deze effecten zijn waargenomen in observationeel onderzoek en in experimentele studies, maar in het algemeen bij relatief hoge concentraties. In een systematische literatuurstudie op basis van 31 publicaties is (zwak) bewijs gevonden voor een aantal respiratoire effecten door blootstelling aan endotoxine aan lage blootstellingsniveaus in de lucht $\left(<100 \mathrm{EU} / \mathrm{m}^{3}\right)$. Alleen nieuwe studies kunnen antwoord geven of potentiële respiratoire effecten van blootstelling aan lagere niveaus van endotoxinen voorkomen na blootstelling in de buitenlucht, in het bijzonder in gevoelige subgroepen van de populatie.

\section{Analyse respiratoire effecten $V G O$ in relatie tot omgevingsniveaus endotoxine}

Her-analyse van de VGO medische onderzoeksgegevens voor atopie, gedefinieerd als sensibilisatie of aanwezigheid van antilichamen tegen algemeen voorkomende allergenen, luchtwegklachten en longfunctie met de berekende PM10- en endotoxineconcentratie op het woonadres levert een aantal statistisch significante verbanden op. Van de 12 variabelen die eerder in de VGO studie zijn onderzocht (atopie (sensibilisatie tegen minstens één allergeen uit een panel milieu-allergenen of verhoogd totaal IgE) (1)), longfunctie (4) en respiratoire aandoeningen/symptomen (7)) waren er, 
uitgaande van de 'fit' van de modellen, 6 het sterkst geassocieerd met de endotoxineconcentratie in de lucht op het woonadres, 4 met dichtheid van veehouderijen rond de woning en 1 met de afstand tot de dichtstbijzijnde veehouderij en 1 met de PM10 concentratie in de lucht op het woonadres. In het kort betreft het de volgende verbanden:

- $\quad$ Er wordt een sterk en statistisch significant verband gevonden tussen atopie en de gemodelleerde endotoxine-concentratie op het woonadres van de deelnemers aan het VGO medisch onderzoek. Deze analyse bevestigt de eerder waargenomen beschermende effecten voor atopie bij omwonenden van veehouderijbedrijven, maar nu specifiek in relatie tot endotoxineconcentraties op het woonadres. De relatie tussen de PM10 concentratie op het woonadres en atopie was zwakker maar ook nog statistisch significant.

- In de VGO-studie bleken meerdere respiratoire symptomen samen te hangen met de dichtheid van veehouderijbedrijven rond de woning (maar niet de afstand tot het dichtstbijzijnde veehouderijbedrijf). Het betrof onder meer piepen op de borst, piepen op de borst en kortademigheid, en piepen op de borst in afwezigheid van een verkoudheid. In deze her-analyse zijn de gevonden associaties (nu tussen respiratoire symptomen en berekende endotoxineconcentraties) in grote lijnen vergelijkbaar. De associaties tussen endotoxineblootstelling, piepen op de borst, en piepen op de borst en benauwdheid waren sterker in vergelijking met de associaties die eerder in de VGO-studie beschreven zijn op basis van dichtheid van veehouderij rond de woning. Ook waren associaties tussen endotoxine en de gezondheidseffecten sterker dan voor de PM concentratie op het woonadres. De associatie tussen endotoxine en piepen op de borst wordt gekenmerkt door een initiële afname in klachtenprevalentie met toenemende omgevingsconcentraties endotoxine en bij verdere toename van de endotoxineconcentratie een toename in de klachtenprevalentie.

- De associaties tussen omgevingsconcentraties endotoxine en de longfunctie zijn in het algemeen relatief zwak. De richting en de vorm van de associaties zijn in grote lijnen vergelijkbaar met wat in het VGO-onderzoek is gevonden. Er zijn geen statistisch significante associaties gevonden tussen de PM10 concentratie op het woonadres en de longfunctie. In het VGO-onderzoek is daarnaast nog gevonden dat de longfunctie lager was op dagen met hoge ammoniakniveaus in de buitenlucht. In dit laatste geval was sprake van een veel sterker verband. Omdat met verspreidingsmodellen niet goed voorspeld kan worden op welk tijdstip de concentratie luchtverontreiniging (en dus ook endotoxine) is verhoogd, zijn geen verdere pogingen ondernomen om deze temporele associaties te onderzoeken met gemodelleerde endotoxineconcentraties.

De associaties tussen klachten en medicijngebruik en afstand van een veehouderijbedrijf/dichtheid van bedrijven rond de woning onder COPD-patiënten werden niet gereproduceerd voor endotoxineconcentraties op het woonadres, maar het onderscheidend vermogen van deze analyse is beperkt door het beperkte aantal personen dat in deze analyse is betrokken.

De PM10- en endotoxineconcentratie op een bepaald punt wordt bepaald door een combinatie van meerdere variabelen, waaronder het aantal veehouderijen, maar ook de afstand tot veehouderijen, het type veehouderij, de omvang van het bedrijf (aantallen dieren), ruigheid van het terrein. Zowel LUR- als dispersiemodellering nemen de invloed van deze variabelen in meer of mindere mate mee. Eerdere analyses in het VGO onderzoek zijn gebaseerd het gebruik van enkele geïsoleerde variabelen (afstand tot de woning, dichtheid veehouderijbedrijven rond de woning) die de PM10- en endotoxineblootstelling maar ten dele verklaren. Dit speelt een rol bij de interpretatie van deze 
associaties op basis van gemodelleerde PM10- en endotoxineconcentraties in vergelijking met eerdere analyses in de VGO studie.

De endotoxine blootstelling is, uitgedrukt als jaargemiddelde endotoxineblootstelling, zelfs voor de allerhoogst blootgestelden, relatief laag en bedraagt enkele $\mathrm{EU} / \mathrm{m}^{3}$. Gegeven de kennis over effecten van endotoxine, lijkt het niet waarschijnlijk dat dergelijke lage endotoxineniveaus tot effecten leiden. Het is waarschijnlijker dat een hogere jaargemiddelde blootstelling indicatief is voor regelmatige kortdurende blootstelling aan niveaus van tientallen $\mathrm{EU} / \mathrm{m}^{3}$. Dergelijke niveaus komen op locaties met veel veehouderijbedrijven, afhankelijk van de precieze locatie, zo nu en dan tot regelmatig voor, afhankelijk van de specifieke meteorologische omstandigheden (windsnelheid, windrichting) en actuele emissies van omliggende bedrijven.

Samenvattend zijn vergelijkbare en vaak sterkere associaties gevonden voor endotoxineconcentraties in de lucht op het woonadres en gezondheidseffecten dan voor PM10 concentraties. Het sterke verband met sensibilisatie is opmerkelijk. Het feit dat associaties vaak sterker waren in termen van 'model fit' voor endotoxine in vergelijking met de PM10 concentratie op het woonadres, ondersteunt de hypothese dat endotoxine een relevante merker is van vee gerelateerde blootstelling, voorspellend voor gezondheidseffecten. Endotoxinen worden niet geëmitteerd door verkeer en de meeste industriële bronnen. Ook geeft dit aan dat primair fijnstof, geëmitteerd door veehouderijbedrijven, mogelijk specifieke effecten heeft. Het is mogelijk dat endotoxine zelf effecten veroorzaakt, maar stof van veehouderijen bevat tevens andere microbiële componenten die vergelijkbare effecten kunnen veroorzaken.

\section{Algemene conclusies}

\section{Emissiegegevens}

Met dit onderzoek is een eerste basis gelegd voor het beschrijven van endotoxineconcentraties in de lucht in de woonomgeving. Deze modellering is mogelijk gemaakt door allereerst endotoxineemissie informatie op basis van metingen te verzamelen. Emissie-informatie is op basis van dit project en voorgaande projecten voor alle diersoorten beschikbaar gekomen, maar nog gebaseerd op een beperkt aantal metingen. Voor sommige diersoorten zijn emissiecijfers verkregen door gebruik te maken van beschikbare meetgegevens in stallen (maar geen emissiemetingen) en informatie uit de literatuur). Voor een aantal diersoorten zijn de emissiecijfers als gevolg hiervan met meer onzekerheid omgeven.

\section{Omgevingsconcentraties endotoxine}

Dit onderzoek geeft inzicht in concentraties endotoxine in de omgeving van veehouderijbedrijven. De resultaten laten zien dat op een aantal locaties de door de Gezondheidsraad voorgestelde grenswaarde van $30 \mathrm{EU} / \mathrm{m}^{3}$ wordt overschreden gedurende periodes van 4 uur. De concentratie endotoxine op een zekere plaats wordt bepaald door de aanwezigheid van veehouderijbedrijven. Verschillende typen veehouderijen dragen substantieel bij aan de berekende concentraties waarbij het niet zo is dat altijd een bepaald type veehouderij het sterkst bijdraagt. De bijdrage van verschillende diersoorten varieert van locatie tot locatie omdat de bijdrage wordt bepaald door een combinatie van factoren waaronder het type bedrijf (en diersoort), het aantal dieren per bedrijf en de afstanden tot en het aantal bedrijven van het type in kwestie.

Op dit moment zijn omgevingsconcentraties endotoxine beschikbaar voor een gebied van $70 \times 70$ $\mathrm{km}^{2}$ dat zich bevindt in de Provincies Noord-Brabant en (het noorden van) Limburg. Deze informatie kan nog verder worden gebruikt om specifieke gebieden in kaart te brengen met hoge 
endotoxineconcentraties. Het gebruik van deze informatie is in dit rapport maar voor een paar specifieke locaties verkend. Voor de betreffende Provincies kan deze informatie nog verder worden gebruikt om hotspots die specifieke aandacht vragen verder in kaart te brengen.

Hoe reductie van de endotoxineconcentratie op een bepaalde locatie kan worden gerealiseerd wordt bepaald door meerdere factoren en vooral hoe de combinatie van diersoort, bedrijfsomvang, bedrijfstypen en aantallen bedrijven samen de concentratie endotoxine op een locatie bepalen. Strategieën om op specifieke locaties tot blootstellingsreductie te komen zijn in hoge mate 'hotspot' specifiek.

\section{Validatie van gemodelleerde endotoxine concentraties}

Vergelijkingen van de gemodelleerde endotoxineconcentratie met de op 61 locaties gemeten endotoxineconcentratie laten zien dat gemodelleerde en gemeten concentraties goed overeenkomen als de warmte-emissie wordt meegenomen in de modelberekeningen. Het verspreidingsmodel verklaart een aanzienlijke mate van variatie in de gemeten concentraties op de verschillende locaties. Op specifieke locaties kunnen verschillen tussen gemeten en gemodelleerde concentraties aanzienlijk zijn. Deze afwijkingen kunnen ontstaan door een aantal mogelijke factoren: mogelijk vanwege onnauwkeurigheden in de emissiefactoren, doordat verondersteld wordt dat de emissie per dier constant is en in hoge mate vergelijkbaar tussen bedrijven en doordat de emissiefactoren worden toegepast op de vergunde dieraantallen. Daarnaast zijn er nog andere onzekerheden in de modellering zoals de rol van bebouwing en begroeiing waar geen rekening mee wordt gehouden. Dit is een belangrijk aspect dat meegewogen moet worden in geval van het gebruik van verspreidingsmodellen als basis voor een toetsingskader voor vergunningverlening voor individuele bedrijven. Overigens zullen dergelijke afwijkingen gelden voor welke vorm van emissie dan ook (geur, stof of endotoxine in stof).

\section{Gezondheidseffecten bij lage endotoxineconcentraties}

Het literatuuronderzoek heeft 31 artikelen opgeleverd waarin associaties tussen endotoxineconcentraties $<100 \mathrm{EU} / \mathrm{m}^{3}$ worden beschreven in relatie tot respiratoire gezondheidseffecten. Verschillende studies lieten associaties zien tussen endotoxineblootstelling en het in verhoogde mate voorkomen van respiratoire klachten en een verlaagde longfunctie. De conclusie van een uitgebreide beoordeling van deze studies is dat effecten onder een niveau van 100 $\mathrm{EU} / \mathrm{m}^{3}$ op de luchtwegen plausibel zijn, maar het beschikbare bewijs is relatief zwak en er is meer informatie nodig over endotoxineblootstelling bij deze lage niveaus, met name voor gevoelige groepen.

\section{Analyse associaties endotoxineconcentraties en gezondheidseffecten in de VGO populatie}

Her-analyse van de VGO medische onderzoeksgegevens voor sensibilisatie, luchtwegklachten en longfunctie levert meerdere bevindingen op. Van de 12 gezondheidsvariabelen die eerder in de VGO studie zijn onderzocht (atopie (sensibilisatie tegen minstens één allergeen uit een panel milieuallergenen of een verhoogd IgE niveau) (1)), longfunctie (4) en respiratoire aandoeningen/symptomen (7)), waren er, uitgaande van de 'fit' van de modellen, 7 het sterkst geassocieerd met de endotoxineconcentratie in de lucht op het woonadres, 4 met dichtheid van veehouderijen rond de woning en 1 met de afstand tot de dichtstbijzijnde veehouderij. Samenvattend kan worden gesteld dat voor de omgevingsconcentraties endotoxine vergelijkbare en in meerdere gevallen sterkere (ruimtelijke) associaties zijn gevonden met de in de VGO-studie eerder onderzochte respiratoire gezondheidseffecten en atopie, waarbij met name de zeer sterke associatie tussen de endotoxineconcentratie op het woonadres en lagere prevalentie van atopie opvalt. Het is opvallend dat deze associaties niet duidelijk zijn waargenomen voor PM10 
concentraties op het woonadres. Endotoxine lijkt hiermee een specifieke merker van de microbiële emissies vanuit de veehouderij die mogelijk relevant is voor het risico op gezondheidseffecten.

\section{Aanbevelingen}

De aanzet van dit onderzoek was de vraag of een beoordelingskader voor endotoxine moet worden ontwikkeld zoals dat bestaat voor geurhinder en fijnstof. Het antwoord op deze vraag valt buiten de scope van dit onderzoeksrapport. Echter, gezien de uitkomsten van dit onderzoek is het verstandig een mogelijke rol van endotoxine als veroorzaker van gezondheidseffecten mee te wegen in de beoordeling van PM10 emissies. De toxicologische eigenschappen van endotoxine-houdend stof afkomstig van veehouderijen verschilt naar alle waarschijnlijkheid van dat van PM10 van industriëleen verkeersbronnen.

Met de nu uitgevoerde emissiemetingen in combinatie met verspreidingsmodellering is inzicht ontstaan in omgevingsconcentraties endotoxine in een groot gebied. Met de resultaten van dit onderzoek kan inzicht worden gegeven in effecten van ontwikkelingen in de veehouderij, zoals eventuele veranderingen van de omvang van de veestapel, mogelijke verdere concentratie van de veestapel in minder maar grotere bedrijven, verschuivingen tussen diersoorten (of diersectoren), en emissiereductie van veehouderijbedrijven door technologische ontwikkelingen of beleidsafspraken. Zo nodig kunnen effecten van voorgenomen beleid ook worden voorspeld. Daarom wordt verwacht dat de resultaten van dit onderzoek van belang zullen blijken te zijn in de nabije toekomst en bij zullen dragen aan de discussie en beleidsontwikkeling rondom veehouderij en gezondheid, ook los van de vraag of een beoordelingskader moet worden ontwikkeld.

Hoewel de overeenkomst tussen gemodelleerde en gemeten endotoxineconcentraties goed is, roepen de uitkomsten van het onderzoek ook vragen op. De overeenkomst was alleen goed als de warmte-emissie in de modellering werd meegenomen. De warmte-emissie wordt gewoonlijk niet meegenomen voor dispersiemodellering van emissies van de veehouderij (geur en fijnstof). Deze uitkomst kan mogelijk bredere consequenties hebben, in alle gevallen waarin gebruik wordt gemaakt van emissiemodellering voor beleidsdoeleinden, maar hiervoor is allereerst verder validatieonderzoek noodzakelijk.

Het is van belang om op te merken dat associaties tussen endotoxineblootstelling en het voorkomen van longontsteking niet nader zijn onderzocht; dit viel buiten het bestek van deze studie. Het was in het kader van deze studie niet mogelijk om analyses in een grote studiepopulatie (VGObronpopulatie van meer dan 100000 personen) uit te voeren. Gezien de uitkomsten van dit onderzoek, en het feit dat voor longontstekingen op dit moment de duidelijkste aanwijzingen bestaan voor een associatie met (bepaalde typen) veehouderij, wordt aanbevolen deze associatie nader te onderzoeken gebruik makend van de gemodelleerde endotoxineconcentratie op leefniveau zoals in kaart gebracht in deze studie. Deeltjesvormige luchtverontreiniging is een oorzaak van longontsteking. Er zijn aanwijzingen in de literatuur te vinden dat endotoxineblootstelling dit risico kan vergroten.

De gegenereerde informatie over endotoxineconcentraties in de buitenlucht over een groot gebied in Nederland met veel intensieve veehouderij is in deze rapportage maar beperkt ontsloten. De beschikbare gegevens lenen zich voor een gebiedsgerichte benadering waarbij op basis van gemodelleerde gegevens 'hotspot' gebieden kunnen worden geïdentificeerd waar zich regelmatig hoge endotoxineniveaus voordoen. Voor deze gebieden kan onderzocht worden of aanvullende maatregelen voor fijnstofemissies of endotoxine-emissies wenselijk zijn om de omgevingsniveaus te beperken. Dat kan handvatten opleveren om effecten van emissies op omgevingsconcentraties endotoxine te verminderen, met name in de gebieden met een grote dichtheid van bedrijven. 


\section{VERKLARENDE WOORDENLIJST}

Begrip of afkorting

Aerodynamische diameter

Big, biggen

BVB of Web-BVB

CV

Deeltjesgrootteverdeling

Dichtheid

Emissie

Emissiefactor

Endotoxine

Endotoxineconcentratie

Endotoxinegehalte

ECRHS

\section{Verklarende tekst}

De aerodynamische diameter van een deeltje is gelijk aan de diameter van een bolvormig deeltje met een dichtheid van $1 \mathrm{~g} / \mathrm{cm} 3$ dat dezelfde terminale valsnelheid heeft als het deeltje in kwestie

Mannelijke en vrouwelijke varkens die zijn gespeend vanuit een kraamstal naar een biggenafdeling om daar in circa 6 weken te groeien van circa 6 naar $25 \mathrm{~kg}$ om vervolgens als vleesvarken te dienen op hetzelfde bedrijf (bij een gesloten bedrijf met zowel een vermeerdering als afmesten) of op een vleesvarkensbedrijf

Bestand Veehouderij Bedrijven of internet versie van het Bestand Veehouderij Bedrijven

'Coefficient of variation': zie variatiecoëfficiënt

Een gegevenstabel of figuur die aangeeft hoe groot de relatieve bijdrage van elke deeltjesgrootte ( $\mu \mathrm{m}$; doorgaans in deeltjesgrootteklassen) is ten opzichte van het totaal van de in de lucht aanwezige deeltjes. Verdelingen kunnen worden gegeven voor aantallen deeltjes of de massa van deeltjes. In dit rapport is het laatste aan de orde

Zie soortelijk gewicht

In algemene zin: uitstoot van een component (bijv. stof, endotoxine). In kwantitatieve zin gebruikt om de uitstootsnelheid te karakteriseren, bijvoorbeeld in $\mathrm{mg} /$ uur (gehele stal) of $\mathrm{mg} /$ uur per aanwezig dier

Uitstoot van een component zoals vastgelegd in regelgeving, uitgedrukt per tijdseenheid en eenheid van productie. Bijvoorbeeld: $g$ /dierplaats per jaar voor $\mathrm{PM}_{10}$

Deeltjes uit het buitenmembraan van Gram-negatieve bacteriën die vrijkomen wanneer de bacterie sterft en desintegreert. Bij inhalatie van zwevende endotoxinen kunnen negatieve gezondheidseffecten optreden, zowel lokaal als systemisch in het lichaam, en zowel acuut als chronisch Concentratie van in de lucht zwevend endotoxine (als onderdeel van (fijn)stof), uitgedrukt in endotoxine units (EU)/m3 lucht

Gehalte van endotoxine in het stof, uitgedrukt in endotoxine units (EU)/mg stof

'European Community Respiratory Health Survey': een grote pan-Europese epidemiologische studie naar aandoeningen van de luchtwegen en mogelijk oorzaken. Het ECRHS onderzoeksteam heeft ook een belangrijke rol in standaardisatie van onderzoeksmethoden voor onderzoek naar 
EU

FEV1

FVC

Inhaleerbaar stof

Leghen, leghennen

LUR model

$\mathrm{m}^{3}$

$\mathrm{mg}$

Melkvee, melkkoeien

Middelingstijd luchtwegaandoeningen waaronder standaardisatie en ontwikkeling van vragenlijsten

Afkorting voor 'Endotoxin Unit' (endotoxine eenheid). Betekenis: een Endotoxine Unit (EU) is een maat voor de activiteit van het endotoxine. Endotoxinen verschillen in hun biologische activiteit of potentie; de reactiviteit van een endotoxine is niet te relateren aan de massa van het endotoxine. Gewichtshoeveelheden van endotoxine zijn daarom geen goede maat voor de endotoxine activiteit. Uitdrukking van endotoxineconcentraties in EU vermijdt de problemen van de verschillende potenties van verschillende endotoxinen.

'Forced expiratory volume in 1 second': het volume geblazen in één seconde bij geforceerde expiratie vanuit volledige inspiratie

'Forced Vital Capacity': het volume dat bij een geforceerde expiratie wordt uitgeblazen vanuit volledige inspiratie

Massafractie van de in de lucht zwevende deeltjes die het ademhalingsorgaan kan penetreren: in de praktijk stofdeeltjes kleiner dan $100 \mu \mathrm{m}$ aerodynamische diameter (ISO 7708 en EN 481)

Vrouwelijke kip van een specifiek legras dat vanaf 17 weken leeftijd eieren legt voor eiconsumptie

'Land Use Regression model': empirisch regressiemodel dat omgevingsconcentraties luchtverontreiniging associeert aan landgebruik kenmerken, in dit geval aanwezigheid van veehouderij.

Kubieke meter; een volume van 1 meter breed, 1 meter lang en 1 meter hoog Milligram; één duizendste gram. Gelijk aan 1000 microgram ( $\mu \mathrm{g})$ Vrouwelijk rund ouder dan circa 2 jaar dat gehouden wordt voor melkproductie

Het tijdsbestek waarover een gemeten waarde wordt gemiddeld. Relevantie: wanneer korte maar hoge pieken voorkomen in de emissie van stof of endotoxinen zullen deze duidelijk zichtbaar zijn in metingen met een korte middelingstijd. In metingen met een lange middelingstijd echter, zal de korte piek worden 'uitgemiddeld': de piek geeft dan nog maar een kleine verhoging van het gemiddelde. Omdat de acute gezondheidseffecten van endotoxinen reeds na enkele uren kunnen optreden zijn in dit rapport 4-uursgemiddelden gebruikt voor bijvoorbeeld concentraties van stof en endotoxine

'Maximal Mid-expiratory flow': het gemiddelde stroomvolume (flow) tussen $25 \%$ en $75 \%$ van een geforceerde expiratiepoging 
Normale verdeling

Odds Ratio

OR

Pluimdaling

PM

$\mathrm{PM}_{100}$ of PM100

$\mathrm{PM}_{30}$ of $\mathrm{PM} 30$

$\mathrm{PM}_{10}$ of $\mathrm{PM} 10$

$\mathrm{PM}_{2.5}$ of $\mathrm{PM} 2.5$

ppm

PubMed

Standaardafwijking/-deviatie

Soortelijk gewicht

Spline

Terreinruwheid

$\mu \mathrm{g}$

Variatiecoëfficiënt

VC
Een verzameling gegevens is normaal verdeeld wanneer, uitgezet in een frequentiepolygoon, een klokvormige curve ontstaat die beschreven kan worden als symmetrisch rond gemiddelde $\mu$ en met een standaardafwijking $\sigma$

De odds ratio is de verhouding tussen twee verhoudingen of odds van bijvoorbeeld blootgestelden en controles. De odds is de verhouding tussen de waarschijnlijkheid dat een gebeurtenis voorvalt (zal voorvallen) en de waarschijnlijkheid dat ze niet voorvalt (zal voorvallen). Een Odds Ratio $>1$ geeft aan dat er een positief verband is tussen blootstelling en ziekte. Een Odds Ratio $<1$ een negatief verband (of beschermend effect). Een odds ratio gelijk aan 1 geeft aan dat er geen verband is tussen blootstelling en ziekte. Zie Odds Ratio

De gemiddelde daling van de pluim (in $\mathrm{m}$ ) ten opzichte van een pluim die geen neerwaartse daling vertoont (zoals bij gassen)

Afkorting voor Particulate Matter. Synoniem: stofdeeltjes. Betekenis:

'Mengsel van fijne vaste of vloeibare deeltjes van organische en anorganische oorsprong, zwevend in een gasvormig medium' (WHO, 2014)

Zie inhaleerbaar stof

Deeltjes met een aerodynamische diameter van $30 \mu \mathrm{m}$ en kleiner

Deeltjes met een aerodynamische diameter van $10 \mu \mathrm{m}$ en kleiner (EN 12341)

Deeltjes met een aerodynamische diameter van $2,5 \mu \mathrm{m}$ en kleiner (EN 14907)

Afkorting voor 'parts per million'. Betekenis: 1 ppm is gelijk aan 0,01\%. In dit rapport heeft dit betrekking op volumetrische verhoudingen

Database met biomedische bibliometrische informatie:

https://www.ncbi.nlm.nih.gov/pubmed

Symbool: $\sigma$. Afkorting: s.d. Betekenis: een statistisch kengetal dat de mate van spreiding in een gegevensverzameling weergeeft

Massa per eenheid van volume (bijv. g/cm3)

Een spline is een functie die bestaat uit een aaneenschakeling van stukjes van polynomen waarmee flexibel krommen kunnen worden beschreven.

Een lengtemaat voor de gemiddelde obstakelhoogte in het terrein $(\mathrm{m})$. Parameter die wordt gebruikt in verspreidingsmodellering van een stalbron

Microgram: één duizendste milligram of één miljoenste gram

Afkorting: VC. Een relatieve spreidingsmaat: de standaardafwijking (of standaarddeviatie) uitgedrukt als percentage van het gemiddelde Zie variatiecoëfficiënt 
Vleeskuiken, vleeskuikens

Vleesvarken, vleesvarkens

Warmte-emissie

Zeug, zeugen
Zowel mannelijke als vrouwelijke kippen van een specifiek vleesras dat in ca. 6 tot 7 weken een gewicht bereikt van ca. $2,5 \mathrm{~kg}$ om daarna geslacht te worden voor vleesconsumptie

Zowel mannelijke als vrouwelijke varkens die in ca. 6 maanden tijd groeien van ca. $25 \mathrm{~kg}$ naar ca. $115 \mathrm{~kg}$ om daarna geslacht te worden voor vleesconsumptie

In de context van deze rapportage, het vrijkomen van warmte als bijproduct van het houden van dieren

Vrouwelijk varken ouder dan circa 8 maanden dat in groepshuisvesting gehouden wordt voor de productie van biggen 


\section{INLEIDING}

Nederland heeft een aantal regio's met zowel een hoge vee-dichtheid als een hoge bevolkingsdichtheid. In sommige regio's heeft dit geresulteerd in maatschappelijke ongerustheid over mogelijke gezondheidsrisico's van veehouderijbedrijven voor omwonenden. Deze ongerustheid bestaat met name over blootstelling aan stofdeeltjes, micro-organismen en endotoxinen (celwandfragmenten van Gram-negatieve bacteriën) die met de ventilatielucht van stallen worden uitgestoten. ${ }^{1}$ In twee Nederlandse studies, het onderzoek Intensieve Veehouderij en Gezondheid (IVG) en Veehouderij en Gezondheid Omwonenden (VGO), wordt een aantal associaties gevonden tussen het wonen nabij stallen en de gezondheid die wijzen op zowel nadelige als beschermende effecten. ${ }^{2-4}$ Onder andere wordt een verhoogd risico op longontsteking gevonden tot een woonafstand van ongeveer één kilometer van pluimveebedrijven en zijn ruimtelijke (met bijvoorbeeld afstand) en temporele effecten (effecten die variëren in de tijd) op de longfunctie gevonden. Een mogelijke verklaring voor dergelijke verbanden is een verhoogde blootstelling aan fijnstof en endotoxinen. Daardoor kan mogelijk de samenstelling van de (populatie van) bacteriën in de luchtwegen veranderen, waardoor de gevoeligheid voor longontsteking vergroot wordt. ${ }^{5}$ Ook wordt in specifieke gevallen (associaties tussen aanwezigheid van geitenbedrijven en longontsteking) de mogelijkheid van een rol voor zoönotische pathogenen of micro-organismen afkomstig uit stallen of composterende mest opengehouden.

In een eerder advies aan de minister van Volksgezondheid, Welzijn en Sport concludeert de Gezondheidsraad dat studies naar relaties tussen blootstelling en gezondheidseffecten bij omwonenden van veehouderijen schaars zijn en dat de huidige stand der kennis de ontwikkeling van één kwantitatief toetsingskader t.a.v. volksgezondheidsrisico's niet toelaat. ${ }^{6}$ Wel werd als grond voor een specifiek toetsingskader voor endotoxinen een gezondheidskundige grenswaarde voor de algemene bevolking voorgesteld van $30 \mathrm{EU} / \mathrm{m}^{3}$ (EU; 'endotoxine units'). Met het beschikbaar komen van een gezondheidskundige advieswaarde voor endotoxinen is een eerste basis ontstaan voor het ontwikkelen van een kwantitatief toetsingskader voor emissies van endotoxinen uit de veehouderij, zoals deze reeds bestaan voor ammoniak, fijnstof en geur.

Als reactie op het voornoemde advies van de Gezondheidsraad is op 14 juni 2013 een kabinetsbrief verschenen. Hierin is aangegeven dat de Staatssecretaris van Infrastructuur en Milieu de gezondheidskundige advieswaarde nader zal uitwerken en vastleggen zodat deze ter bescherming van de gezondheid van omwonenden van veehouderijen kan worden toegepast bij het verlenen van de omgevingsvergunning milieu. Naast een gezondheidskundige grenswaarde dient een toetsingskader een instrumentarium te bevatten waarmee de blootstelling in de omgeving t.g.v. veehouderijactiviteiten in kaart wordt gebracht, zodat getoetst kan worden of de grenswaarde ter hoogte van een toetsingspunt overschreden wordt. Naar analogie van het toetsingskader voor fijnstof, ammoniak en geur kan dit instrumentarium bestaan uit een verspreidingsmodel waarin emissiefactoren zijn opgenomen. In het licht van bovenstaande voorgeschiedenis is door de Rijksoverheid aan een consortium van Wageningen Livestock Research, Wageningen Bioveterinary Research, IRAS-Universiteit Utrecht en Erbrink Stacks Consult gevraagd onderzoek te doen naar ontwikkeling van een hierboven geschetst toetsingskader voor endotoxine-emissies uit stallen. Deze onderzoeksopdracht is uitgevoerd binnen het kader van het Beleidsondersteunend onderzoek van het Ministerie van Landbouw, Natuur en Voedselkwaliteit (BO-20-004-114), met financiering van het Ministerie van Infrastructuur en Waterstaat. 


\section{Eerste rapport: literatuurstudie}

Het ontwikkelen van een dergelijk toetsingskader riep een groot aantal vragen op die beantwoording vergden alvorens tot ontwikkeling kon worden overgegaan. In een eerste deel van het onderzoek is aan de hand van deze vragen een literatuurstudie uitgevoerd met daarin de stand van kennis over endotoxine-blootstelling in de veehouderij en rond bedrijven. ${ }^{7}$ De conclusie van dat rapport was dat de kennis over emissies van endotoxinen voor de Nederlandse situatie ontoereikend is om direct een toetsingskader te ontwikkelen. Verder leken oriënterende berekeningen (met een aantal noodzakelijke aannames) erop te wijzen dat huidige toetsingskaders voor fijnstof en geur niet al in voldoende mate bescherming bieden tegen te hoge endotoxinebelastingen, hoger dan de door de Gezondheidsraad voorgestelde grenswaarde, met name bij omwonenden van pluimveestallen. In het rapport werd aanbevolen om bron-technische informatie te verzamelen (endotoxinegehalten in stalstof; verdeling van endotoxinen over deeltjesfracties van stof, enzovoort) en bestaande verspreidingsmodellen aan te passen voor verspreidingsberekeningen voor endotoxine.

\section{Tweede rapport: eerste emissiefactoren en verspreidingsmodel voor een puntbron}

In een tweede deel van het onderzoek is een eerste set emissiefactoren verkregen door metingen uit te voeren van de emissie van endotoxinen uit in totaal zes stallen voor leghennen, vleeskuikens en vleesvarkens. ${ }^{8}$ Een verspreidingsmodel voor endotoxinen is verkregen door een variant van het STACKS model hiervoor geschikt te maken. Dit betekent o.a. dat de modelvariant kan rekenen met deeltjes groter dan $10 \mu \mathrm{m}\left(>\mathrm{PM}_{10}\right)$, met depositie van die deeltjes t.g.v. hun massa en met een endotoxinegehalte in de deeltjes. Uit de emissiemetingen bleek dat het endotoxinegehalte in het stof varieert tussen diercategorieën en toeneemt met de deeltjesgrootte. Dit betekent dat voor verspreidingsberekeningen in een toetsingskader niet kan worden volstaan met een constant endotoxinegehalte in alle stofdeeltjes maar dat onderscheid nodig is naar diercategorie en deeltjesgrootteklasse. Uit de verspreidingsberekeningen bleek dat de huidige toetsingskaders voor fijnstof en geur voor pluimveebedrijven (vleeskuikens en leghennen) niet voldoende beschermend zijn tegen het overschrijden van de gestelde endotoxine grenswaarde $\left(30 \mathrm{EU} / \mathrm{m}^{3}\right)$. De berekeningen voor vleesvarkensbedrijven gaven aan dat het toetsingskader voor geur daar voldoende beschermend werkt. Deze verspreidingsberekeningen zijn gedaan voor de situatie van één bedrijf; er zijn geen situaties doorgerekend met meerdere bronnen in een relatief klein gebied waar stapeling (zogenaamde 'cumulatie') op kan treden. In een gevoeligheidsanalyse van het verspreidingsmodel zijn de effecten onderzocht van vier variabelen: depositiesnelheid (de snelheid waarmee deeltjes uit de pluim verdwijnen door sedimentatie en impactie), pluimdaling (de mate van neerwaarts/horizontaal gericht zijn van de pluim-as), variatie in endotoxinegehalte in de deeltjes en de mate van terreinruwheid. Uit deze gevoeligheidsanalyse bleek met name de depositie een grote invloed te hebben op de berekende concentraties en overschrijdingsafstanden. Uit de studie werd aanbevolen de eerste set emissiecijfers uit te breiden met aanvullende metingen: zowel voor reeds betrokken diercategorieën (leghennen, vleeskuikens en vleesvarkens) als voor andere belangrijke diercategorieën, zoals bijvoorbeeld zeugen, biggen en melkkoeien. Daarnaast werd aanbevolen om een meetmethode te ontwikkelen voor een deeltjesfractie tussen $\mathrm{PM}_{10}$ en $\mathrm{PM}_{100}$ (bijvoorbeeld $\mathrm{PM}_{30}$ ) om in dit traject het endotoxinegehalte in het stof nauwkeuriger te kunnen differentiëren.

\section{Derde rapport: verdere uitbouw meetinspanning emissiefactoren}

In het derde onderzoeksrapport in de reeks is de eerste set emissiecijfers uitgebreid tot een totaal van 60 endotoxinemetingen, verricht bij een totaal van 18 stallen voor leghennen, vleeskuikens, vleesvarkens, zeugen, biggen en melkkoeien. ${ }^{9}$ Daarnaast bevat dit rapport twee literatuurstudies die inzichten opleveren voor het juist vormgeven van de modellering van endotoxinen vanuit stallen naar leefomgeving en omwonenden. 


\section{Deze rapportage}

Dit onderzoeksproject richt zich op de beoordeling van de betekenis van het voorstel van de Gezondheidsraad voor een grenswaarde voor de algemene bevolking voor endotoxine en verkenning van relaties met gezondheidseffecten. Meer specifiek zijn de doelstellingen:

- Een regionaal (model)instrument ontwikkelen waarmee de heersende blootstelling aan endotoxine als gevolg van emissies van veehouderijen in het onderzoeksgebied (primair het VGO-onderzoeksgebied) kan worden onderzocht, en dat ook geschikt is om het effect van nieuwvestigingen en emissie-reducerende maatregelen op de blootstelling van omwonenden te berekenen.

- Met behulp van dit instrument onderzoeken:

o Wat de heersende blootstelling aan endotoxine is als gevolg van emissies van veehouderijen en onderzoeken in welke mate de tentatieve grenswaarde voor endotoxine overschreden wordt op woonlocaties.

o Welke relaties er zijn tussen endotoxineblootstelling en gezondheidseffecten bij omwonenden en wat de omvang is op populatieniveau van de effecten gerelateerd aan endotoxineblootstelling.

Ten behoeve van deze doelstellingen bestond het project uit meerdere onderdelen. Voor het modelleren betroffen deze onderdelen:

- Ontwikkeling van het modelinstrument in de vorm van pluimmodellering van de endotoxineconcentratie in een groter gebied op leefniveau. Hierin wordt voor de beschrijving van de bronemissie gebruik gemaakt van gegevens die afgelopen jaren verzameld zijn in een reeks projecten waarin de endotoxine-emissie is gekwantificeerd voor meerdere diersoorten en bedrijfstypen.

- Berekening van 4-uurs endotoxineconcentraties in het gehele gebied dat in de VGO-studie is onderzocht (oostelijk deel Noord-Brabant en noorden van Limburg). Dit geeft een beeld van de locaties waar regelmatig overschrijding van de door de Gezondheidsraad voorgestelde grenswaarde van $30 \mathrm{EU} / \mathrm{m}^{3}$ plaatsvindt.

- Validatie van de gemodelleerde endotoxineconcentraties met omgevingsmetingen die in het kader van de VGO-studie zijn verzameld voor 61 meetpunten gedurende een periode van een jaar.

Het gezondheidseffectendeel van het onderzoek bestond uit de volgende onderdelen:

- Systematisch literatuuronderzoek naar effecten van endotoxine op de luchtwegen bij lage concentraties.

- Analyse van blootstelling-respons relaties door de endotoxineconcentratie op het woonadres te koppelen aan gezondheidsgegevens die verzameld zijn in het medisch onderzoek van de VGO-studie (respiratoire symptomen, longfunctie, allergische sensibilisatie). Indien relaties worden aangetoond kan de bijdrage van endotoxine aan het voorkomen van de gezondheidseffecten worden onderzocht.

De resultaten van dit onderzoek dragen bij aan een antwoord op de vraag of het huidige toetsingskader voor emissies van veehouderijbedrijven, dat gebaseerd is op geur- en fijnstofemissies, moet worden uitgebreid met een toetsing op endotoxineconcentraties in de omgeving. 


\section{Leeswijzer}

Om dit rapport zo kort mogelijk en toegankelijk te houden zijn alleen de meest essentiële resultaten beschreven. De resultaten en de daarbij gebruikte methoden zijn in drie delen uitgewerkt. Het eerste onderdeel omvat de modellering van de endotoxineconcentratie in de omgeving, met daarin ontwikkelingen van het rekenmodel, berekening van de endotoxine-concentraties in het studiegebied en validatie van de berekende waarden met meetgegevens uit de VGO-studie. Het tweede deel rapporteert het literatuuronderzoek naar de gezondheidseffecten van endotoxine bij lage concentraties. In het derde deel worden tenslotte de resultaten van de analyse van blootstelling-responsrelaties in het studiegebied gepresenteerd en besproken.

Voor technische details en gedetailleerde resultaten wordt verwezen naar de bijlagen, rapportages van eerder onderzoek naar emissie van endotoxine ${ }^{7-9}$, VGO-rapportages en artikelen ${ }^{40-13}$ en de VGO-website (www.rivm.nl/vgo) waarop informatie over de achtergronden van de VGO-studie te vinden is en meer details over de gegevens die gebruikt zijn in deze studie. Separaat zullen artikelen verschijnen over de resultaten van dit onderzoek die een gedetailleerde verantwoording geven van de gehanteerde methoden en resultaten. 


\section{MODELLERING VAN ENDOTOXINECONCENTRATIES IN DE LEEFOMGEVING}

\section{Inleiding}

Om tot modellering van endotoxineconcentraties in het onderzoeksgebied in Noord-Brabant en Limburg te komen is een aantal stappen nodig, waaronder het geschikt maken van beschikbare verspreidingsmodellen, en het organiseren van invoergegevens waaronder informatie over stallen en veehouderijbedrijven en emissiefactoren. Deze onderdelen worden hieronder kort beschreven, alsook de gekozen aannames in de berekeningen, en een verantwoording daarvan. Daarna volgen resultaten en een validatie van de modeluitkomsten met metingen die in het kader van de VGOstudie zijn uitgevoerd.

\section{Methoden}

\section{Verspreidingsmodel}

Het rekenmodel STACKS is een implementatie van het Nieuw Nationaal Model (NNM) en voldoet aan de eisen van de 'Standaard Rekenmethode 3' zoals beschreven in Regeling beoordeling luchtkwaliteit 2007. De berekeningen zijn uitgevoerd conform het 'Nieuw Nationaal Model (NNM)' én de 'Aanvullende afspraken NNM' zoals beschreven in de 'standaardrekenmethode 3 (SRM3)' met uitbreidingen voor pluimdaling en als gevolg daarvan een proportioneel groter massaverlies voor grotere deeltjes. STACKS is een versie van het NNM dat door deskundigen in Nederland wordt gezien als het best beschikbare model voor het bepalen van de invloed van (onder meer) industriële bronnen en stallen. STACKS berekent voor ieder uur de gemiddelde concentratie, gebruikmakend van het Gaussisch pluimmodel. Dit wordt de uur-voor-uur methode genoemd. Voor ieder berekend uur zijn meteorologische gegevens nodig. De meteorologische gegevens van een geselecteerde periode van 5 tot 10 jaar worden hiervoor gebruikt. Uit deze gegevens berekent het model o.a. de stabiliteit van de atmosfeer en uiteindelijk de concentratie en depositie ten gevolge van de pluim.

Het Gaussisch pluimmodel heeft als kenmerk dat het de vorm van de pluim zowel in horizontale als verticale richting beschrijft met een Gaussische (normale) concentratieverdeling. Het model is in Nederland in detail beschreven. ${ }^{14}{ }^{15}$ De dispersieparameters $\sigma_{y}$ en $\sigma_{z}$ worden berekend met behulp van de Taylor dispersie theorie; de benodigde turbulentieparameters zijn daarbij (analoge) functies van de relevante fysische parameters zoals de wrijvingssnelheid en Monin-Obukhov lengteschaal en de grenslaaghoogte.

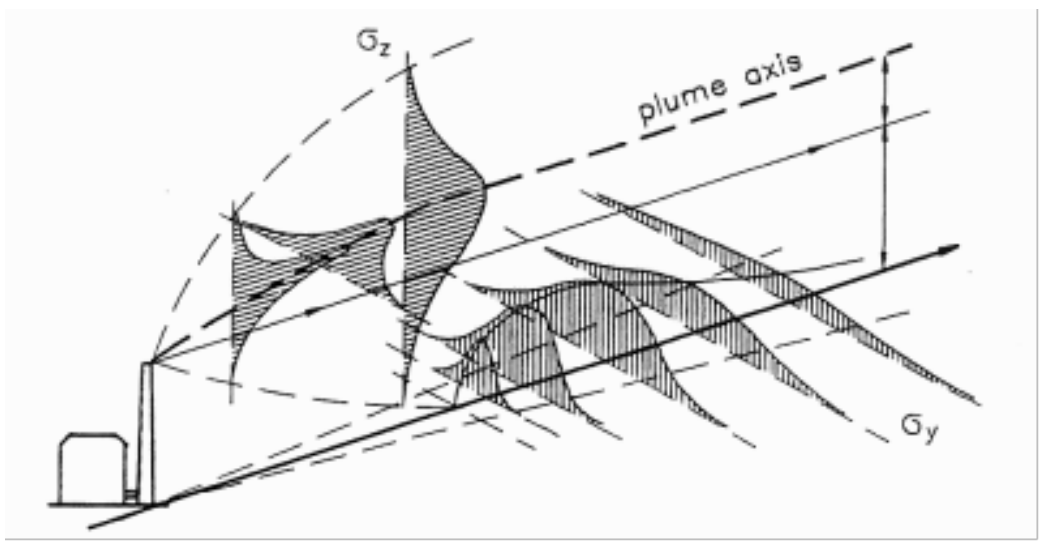

Figuur 1. Een schematische voorstelling van het Gaussisch pluimmodel met dispersieparameters $\sigma_{\mathrm{y}}$ en $\sigma_{\mathbf{z}}$. 
Een voordeel van de uur-voor-uur methode is dat bronsterkte en warmte-inhoud per uur kunnen variëren. Nadeel is dat het programma reken-intensiever is vergeleken met modellen die gebruik maken van geclassificeerde meteorologie, zoals dat gebruikelijk is in lange-termijnmodellen. In STACKS is een module aanwezig om de obstructie door een gebouw (waar de bron op of naast staat) in detail mee te kunnen bepalen. Deze zogenaamde gebouwmodule behoeft echter ook detailinvoer van de gebouwafmetingen en oriëntatie ten opzichte van de windrichting. Voor vergunningverlening zijn deze gegevens uiteraard beschikbaar, maar in het BVB-bestand (Bestand Veehouderij Bedrijven) ontbreken deze meestal. $\mathrm{Er}$ is daarom een benaderende gebouwmodellering in STACKS opgenomen, zoals die in V-Stacks aanwezig is, die alleen informatie gebruikt over stalhoogte en emissiehoogte. Voor alle endotoxine-berekeningen is deze benaderende rekenmethode toegepast.

\section{Depositie}

Droge depositie is het verticale transport van gassen of deeltjes, doordat deze zich hechten aan het aardoppervlak. Door deze verwijdering aan het oppervlak ontstaat een concentratiegradiënt, die zorgt voor het verticale transport. De snelheid van depositie is afhankelijk van de stabiliteit van de atmosfeer, de ruwheid van het aardoppervlak (ruwheidslengte), het landgebruik, en de periode van het jaar. Bij stofdeeltjes is daarnaast ook de deeltjesgrootte van belang.

Natte depositie bestaat uit twee processen, het uitregenen en het uitwassen. Het uitregenen vindt plaats in een regenwolk en het uitwassen onder een regenwolk. ${ }^{16}$ Beide processen hangen af van de grootteverdeling van het stof. Het uitwassen is van belang dicht bij de bron, het uitregenen wat verder weg van de bron. Voor kleine bronnen en op korte afstanden $(<1 \mathrm{~km})$ is natte depositie relatief van weinig belang. Bij de modellering van endotoxinen wordt daarom alleen de droge depositie in rekening gebracht. Door het verdwijnen van stof uit de pluim neemt de bronterm (de oorspronkelijke emissie) af. In het model wordt gedetailleerd bijgehouden welk deel van de emissie op een gegeven afstand nog aanwezig is. Omdat voor deeltjes deze verdwijnterm sterk afhangt van de deeltjesgrootte wordt dit massaverlies per deeltjesgrootteklasse berekend. Daarmee wordt feitelijk een concentratieberekening uitgevoerd voor elke deeltjesgrootte. De emissie wordt zo opgedeeld in 10 sub-emissies, voor elk waarvan het eigen verspreidings- en depositieproces wordt doorgerekend. De blootstelling aan endotoxine in $\mathrm{PM}_{100}$ fractie wordt dan verkregen door de 10 fracties weer bij elkaar op te tellen op het receptorpunt.

Sedimentatie is het uitzakken van deeltjes uit de pluim, als gevolg waarvan de pluim zelf ook langzaam daalt met toenemende afstand (zie figuur). Gewoonlijk wordt de verspreiding berekend door aan te nemen dat de hoogte van de pluim niet verandert met toenemende afstand. Voor de grotere deeltjes geldt dat echter niet meer; door de niet te verwaarlozen sedimentatiesnelheid van de deeltjes daalt de gemiddelde pluimhoogte ook. De pluimdaling verschilt voor elk van de 10 deeltjesklassen en wordt sterker bij toenemende deeltjesgrootte. Naast sedimentatie vindt depositie plaats. Omdat in het depositieproces sedimentatie (onder invloed van zwaartekracht) al is opgenomen moet een keus gemaakt worden wanneer sedimentatie de dominante factor wordt. In overeenstemming met het OPS-model is ervoor gekozen voor deeltjes groter dan $20 \mu \mathrm{m}$ pluim-as daling onder invloed van sedimentatie toe te passen. Door materiaalverlies uit de pluim neemt de oorspronkelijke bronterm af. Voor kleinere deeltjes geldt het normale depositieproces. Bij dit depositieproces daalt de pluim-as niet, maar neemt de bronterm wel af doordat er materiaalverlies optreedt. De depositie wordt gestuurd door impactie van deeltjes aan bodem, vegetatie en andere obstakels. De impactie is deeltjesgrootte-afhankelijk (via de ruwheidsfactor) en afhankelijk van het soort ondergrond. 


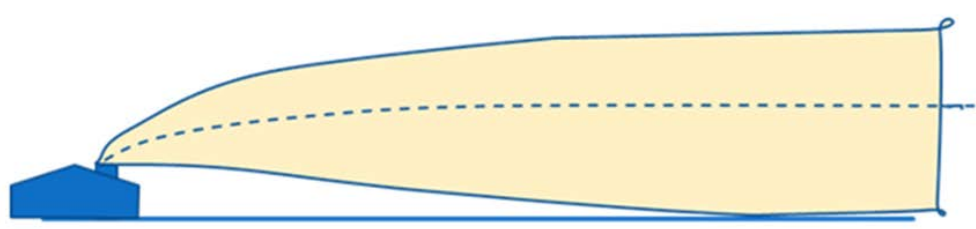

Lichte deeltjes

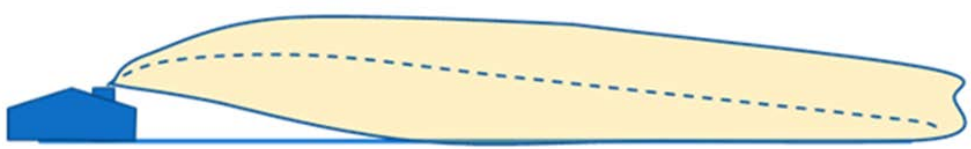

Zware deelties

Figuur 2. Een schematische voorstelling van het effect van pluimdaling voor de zwaardere deeltjes.

Hiermee is een model beschikbaar dat ingezet kan worden om endotoxineniveaus rond stallen te kunnen bepalen. Om een groot aantal stallen door te kunnen rekenen, zijn invoergegevens en een modelleringsstrategie nodig waarmee efficiënt resultaten kunnen worden verkregen. Achtereenvolgens worden de invoergegevens besproken en daarna de werkwijze (de modelleringsstrategie) om tot resultaten te komen.

Invoergegevens

De invoer van het rekenmodel bestaat uit kenmerken van alle stallen die in Brabant en Limburg aanwezig zijn, parameters waaronder deeltjesgrootte-verdeling, stofemissie en endotoxineconcentratie in stof die door de diersoort wordt bepaald. En tenslotte omvatten de invoergegevens de meteorologische gegevens en ruwheidsgegevens. In onderstaande figuur zijn het rekenproces en de gebruikte gegevens schematisch weergegeven (figuur 3). Deze worden hierna achtereenvolgens besproken.

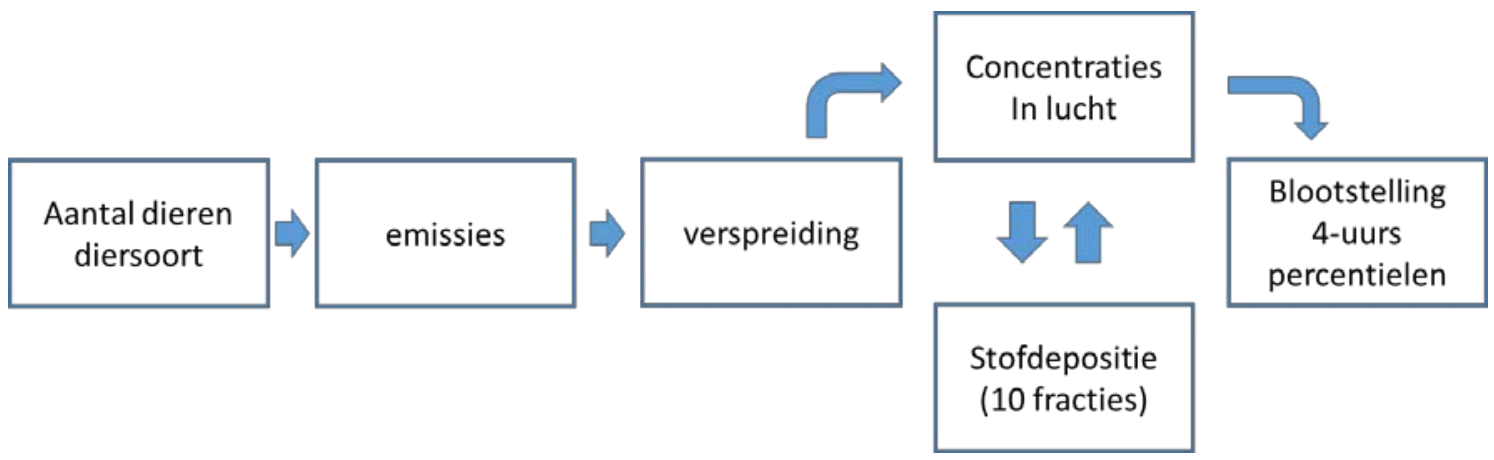

Figuur 3. Het rekenproces: startend met gegevens over stalkenmerken worden 4-uurs gemiddelde endotoxineconcentraties bepaald.

\section{Modeluitkomsten: 4-uurs percentielwaarden}

Voor de uitvoer van de modelberekeningen is gekozen voor een middelingsduur van 4-uur omdat bekend is dat endotoxine acute respiratoire effecten kan veroorzaken. Op basis van deze informatie kunnen jaargemiddelde concentraties voor een bepaalde locatie worden berekend en kan de verdeling van 4-uurs waarden worden bepaald. Voor de door de Gezondheidsraad voorgestelde grenswaarde van $30 \mathrm{EU} / \mathrm{m}^{3}$ is geen middelingsduur gegeven waarover deze concentratie moet worden beoordeeld. Voor 4 uur is gekozen omdat de door de Gezondheidsraad voorgestelde 
grenswaarde van $30 \mathrm{EU} / \mathrm{m}^{3}$ is afgeleid van de resultaten van een experimentele studie waarin proefpersonen zes uur zijn blootgesteld aan endotoxine-houdend stof. ${ }^{17}$ Ook zijn gegevens beschikbaar van onderzoek waarbij proefpersonen in zeer korte tijd éénmalig een hoge dosis zuiver endotoxine hebben geïnhaleerd en waarmee acute luchtwegobstructies worden opgewekt. ${ }^{18}$ Daarnaast worden in meerdere publicaties acute effecten beschreven, waaronder respiratoire inflammatie en acute longfunctieverandering, na blootstelling van perioden van enkele uren. Voor een overzicht wordt naar de rapportages van de Gezondheidsraad verwezen. ${ }^{619}$ Daarom werd voor de beoordeling van de endotoxineconcentratie in de omgeving een korte middelingsduur essentieel geacht. Het leek daarom redelijk om de endotoxineconcentratie voor een dagdeel als uitgangspunt voor de verdere berekening te nemen (4-uur).

Omdat voor endotoxineblootstelling geen beoordelingskader of regelgeving bestaat, in tegenstelling tot de regelgeving voor geurhinder en fijnstof, zijn meerdere percentielwaarden voor overschrijding van de door de Gezondheidsraad voorgestelde grenswaarde van $30 \mathrm{EU} / \mathrm{m}^{3}$ doorgerekend variërend van $98,0 \%, 98,5 \%, 99,0 \%$ tot $99,9 \%$. Het 98 -percentiel is een vrij gebruikelijke percentielwaarde voor toetsing van buitenluchtnormen omdat extreme weersomstandigheden, en de daaruit voortvloeiende hoge concentraties luchtverontreiniging, moeilijk kunnen worden gecontroleerd. Een 98-percentielwaarde voor 4-uursperioden per jaar betekent dan dat gedurende 44 tijdstippen van 4 uur, gemiddelde niveaus worden toegestaan met hogere waarden dan $30 \mathrm{EU} / \mathrm{m}^{3}$. Voor de andere percentielwaarden komt dit overeen met respectievelijk 22, 11 en 2 perioden van 4 uur.

\section{Emissiegegevens}

De informatie over endotoxine emissies is afkomstig van 60 metingen die in eerder onderzoek (OBE fase $3 a / 3 b$ ) zijn uitgevoerd. Alle metingen en de daaruit volgende analyse ten behoeve van de endotoxine emissie schattingen zijn eerder gerapporteerd..$^{7-9}$ In het kort, metingen zijn gedaan bij verschillende stallen voor de diersoorten: vleeskuikens, leghennen, vleesvarkens, biggen, zeugen en koeien. In de ventilatie-uitgang is stof verzameld van $\mathrm{PM}_{2,5}, \mathrm{PM}_{10}, \mathrm{PM}_{30}$ of $\mathrm{PM}_{100}$ of een combinatie hiervan. Deze metingen zijn gecombineerd met informatie over de deeltjesgrootte verdeling van het stof (die in eerdere projecten is gemeten met een 'Grimm Aerosol Spectrometer', waarmee 32 kanalen, dus 32 deeltjesgrootten relatief gemeten konden worden), en met met verhoudingsgetallen $\mathrm{PM}_{100} / \mathrm{PM}_{10}$ van de metingen (deels uit deze metingen, deels op basis van de literatuur). Aan de hand hiervan is het endotoxine gehalte (endtoxine per mg stof) in 10 deeltjesgrootte klassen geschat. Voor geiten en paarden zijn geen emissie metingen beschikbaar, maar zijn literatuurgegevens voor de endotoxinegehaltes gebruikt en zijn deeltjesgrootteverdelingen gelijkgesteld aan die gemeten voor zeugen respectievelijk melkvee. Voor eenden is aangenomen dat deeltjesgrootteverdeling en endotoxinegehaltes vergelijkbaar zijn als die voor leghennen, en voor kalkoenen is aangenomen dat deeltjesgrootteverdeling en endotoxinegehaltes vergelijkbaar zijn als die voor vleeskuikens. In Tabel A.1.1. zijn de gemeten en afgeleide gegevens te vinden met voor iedere diercategorie een toelichting hoe de cijfers precies tot stand zijn gekomen (metingen als onderdeel van dit project of voorlopers van dit project of andere meetgegevens die in het verleden in Nederland zijn uitgevoerd). Tabel A.1.2 en A.1.3 bevat het overzicht van de gefitte deeltjesgrootteverdeling per diercategorie, en het endotoxinegehalte per deeltjesgrootte fractie zoals gebruikt bij de modellering. Figuur A.1.1 geeft de modelfit voor de deeltjesgrootteverdeling en endotoxine gehalte voor de diercategorieën geiten en paarden.

\section{Stalgegevens}

Informatie over stalkenmerken zijn uit de Provinciale BVB van Noord-Brabant en Limburg opgehaald. Het BVB (Bestand Veehouderij Bedrijven) bevat gegevens uit de vergunningenmeldingen van veehouderijbedrijven. Dit is een set gegevens die meer dan 30000 stallen omvat. In het BVB zijn de 
gegevens soms van wisselende kwaliteit; met name wat de exacte situering van de stallocaties betreft. Daarom is een sensitiviteitsanalyse uitgevoerd in een deelgebied (rond Nederweert) met een gegevensbestand van ingenieursbureau Tauw, met gedetailleerder gegevens dat voor een ander doel is opgezet en waarbij nauwkeurig is nagegaan of de locatie van de stallen klopt met de werkelijkheid. ${ }^{20}$ Met STACKS is berekend welke verschillen er optreden in de omgevingsconcentratie endotoxine wanneer wordt gerekend met de originele BVB gegevens in vergelijking met de gedetailleerde gegevens.

Ruwheid en meteorologie

Om de berekeningen uit te voeren is een lokale waarde voor de ruwheid nodig. Deze wordt gevonden door de PreSRM tool in te zetten en de ruwheid te bepalen over een gebied van $5 \times 5 \mathrm{~km}^{2}$ rond het receptorpunt. Bij elk receptorpunt wordt dus een locatie specifieke waarde voor de ruwheid gebruikt. In een sensitiviteitsanalyse is met een kleiner gebied van $2 \times 2 \mathrm{~km}^{2}$ gerekend.

De meteorologie wordt bepaald per uur en via de PreSRM tool opgehaald uit een gegevensbestand van het KNMI. De meteorologie wordt met deze tool locatie specifiek gemaakt met een algoritme dat is beschreven in de documentatie van het NNM. Dit is een bewerkelijk proces en zou kunnen leiden tot een (te) lange rekentijd. De parameters waar het om gaat (temperatuur, windrichting, bewolking, zoninstraling) zijn niet erg locatieafhankelijk. Daarom wordt pas een nieuwe set meteoparameters met de PreSRM opgehaald als het actuele receptorpunt meer dan $10 \mathrm{~km}$ van het punt afligt waarvoor de laatste keer de meteorologische waarden zijn opgehaald. De windsnelheid wordt altijd op elk rekenpunt locatie-specifiek berekend; deze hangt namelijk (mede) van de ruwheid en de pluimhoogte af.

Toepassing rekenmodel op BVB-gegevens

Op basis van de RAV-code worden emissie kenmerken die voor de stal van toepassing zijn gekoppeld (zie hierboven). Alle relevante diersoorten worden in de analyse betrokken. De gemeten of uit de literatuur afgeleide kenmerkende endotoxine gehalten in $\mathrm{PM}_{10}$ en $\mathrm{PM}_{100}$ uit tabel A.1.1. worden alleen gebruikt om vooraf de bijdrage van deze stal aan de totale concentratie te schatten (zie hieronder). Bij de verspreidingsberekening wordt gerekend met stof- en endotoxine-gehalten in tien deeltjesgroottefracties uit tabellen A1.1 en A1.2 per deeltjesgrootteklasse (de waarden uit tabellen A.1.2 en A.1.3 in Appendix 1). De $\mathrm{PM}_{10}$ emissie per dier is afkomstig uit het BVB-bestand. Daarnaast zijn er op basis van de RAV-code aannames gedaan over andere stalkenmerken, stalhoogte, uittreesnelheid en emissiehoogte (zie tabel in A1.4).

Om meer dan 30.000 stallen door te rekenen (de gehele Provincies Noord-Brabant en Limburg) moet een beperking opgelegd worden aan het aantal stallen dat per receptorpunt wordt meegenomen in de berekening. Immers, een stal op $10 \mathrm{~km}$ afstand met 100 kippen zal geen significante invloed meer hebben op de 99,5 percentielwaarden. Maar een stal met 200.000 kippen misschien nog wel. Daarom wordt een filtertechniek toegepast om de belangrijkste stallen mee te berekenen en niet relevante stallen juist over te slaan. Dit filter bestaat uit meerdere stappen. Per diersoort is allereerst een analyse gemaakt van de afstandsafhankelijkheid $(X)$ van de berekende concentraties (C). In het algemeen is dit $\mathrm{C}=\mathrm{a} \mathrm{X}^{\mathrm{b}}$. De waarde van $\mathrm{a}_{\text {(diercategorie) }}$ en $\mathrm{b}_{\text {(diercategorie) }}$ zijn correctiefactoren die uit analyses zijn afgeleid en die rekening houden met variërende invloed van de depositie en verschillen per diersoort (zie tabel A.1.4 voor de waarden). Stof bestaande uit zwaardere deeltjes geeft immers sneller een concentratiedaling met de afstand dan stof dat vrijwel alleen uit $\mathrm{PM}_{10}$ bestaat. Stof van de ene diercategorie bevat immers veel meer endotoxine dan bij stof van een andere categorie. De bijdrage van een stal wordt groter als er meer dieren in de stal staan, als het 
endotoxinegehalte hoger is en als de stofuitworp per dier groter is. Dit resulteert in een schatter voor de te verwachten bijdrage van een stal aan de gecumuleerde waarde op afstand X:

$\mathrm{EU}=\mathrm{a}_{\text {(diercategorie) }} * \mathrm{PM}_{10 \text { (diersoort) }} * \mathrm{PM}_{100} / \mathrm{PM}_{10 \text { (diercategorie) }} * \mathrm{EUstof}_{\text {(diercategorie) }} *$ aantal dieren* $X^{\wedge}\left(b_{\text {(diercategorie) })}\right)$.

EUstof $_{\text {(diercategorie) }}$ is het gemiddelde endotoxinegehalte van het stof per diercategorie. Deze formule maakt het mogelijk om vooraf een schatting te maken van de bijdrage van elke stal aan de totale(uur) concentratie op een punt. Met deze formule wordt de bijdrage van elke bron die ligt binnen een afstand van $10 \mathrm{~km}$ tot het receptorpunt bepaald en vervolgens worden deze waarden naar grootte gesorteerd. Van deze gesorteerde waarden worden de 100 grootste (geschatte) bijdragen genomen en voor alleen deze stallen wordt de endotoxineconcentratie in detail berekend.

In een aanvullende sensitiviteitsanalyse is nagegaan welke fout er gemaakt kan worden als er rond een receptorpunt 100 en geen 1000 bronnen worden doorgerekend. Dit is gedaan voor een selectie van 1\% uit de dataset van 14000 receptorpunten (140 punten), aangevuld met enige tientallen punten uit de Nederweert dataset. Deze laatste aanvulling is gedaan omdat in de set van 140 punten er relatief weinig punten zaten met hoge endotoxineconcentraties. De aanvulling bevatte vooral punten met hoge bronbijdragen, zodat er ook punten worden meegenomen waar het 99,5-p ver boven de advieswaarde van de Gezondheidsraad uitkomt.

\section{Procesvariatie in endotoxine-emissie}

Voor vleeskuikens, leghennen en vleesvarkens wordt afgeweken van een vaste emissie. Van deze diersoorten is bekend dat de emissie sterk kan variëren in de cyclus als gevolg van de buitenluchttemperatuur. In de berekeningen is deze cyclus en buitenluchttemperatuur meegenomen. Voor een detailbeschrijving van deze emissievariatie zie KEMA, (2014). De emissie die volgens deze specificatie per uur wordt berekend, wordt wel geschaald naar de juiste $\mathrm{PM}_{10}$ emissie volgens tabel A1.1.

\section{Deeltjesdichtheid}

Als soortelijke massa van alle stofdeeltjes is $1 \mathrm{~g} / \mathrm{cm}^{3}$ genomen, overeenkomstig het inzicht dat de deeltjesdiameters aerodynamische diameters betreffen, waarvoor per definitie 1 gebruikt dient te worden.

\section{Receptorpunten}

Modelberekeningen zijn voor verschillende receptorpunten en tijdstippen uitgevoerd:

- 313000 receptorpunten voor het maken van overzichtskaarten voor een gebied van $70 \times 70 \mathrm{~km}^{2}$ in Noord-Brabant. Gerekend is met de meteorologiegegevens van 2012. De BVBgegevens van 2015 zijn gebruikt.

- 61 meetlocaties waarop in het VGO-onderzoek stof- en endotoxinemetingen zijn uitgevoerd (Figuur 4). De met het rekenmodel berekende concentraties voor deze locaties zijn vergeleken met gemeten endotoxine-concentraties op basis van de in de VGO-studie gemeten endotoxine concentraties op leefniveau.

- woonadressen van deelnemers aan het VGO-onderzoek. Het betreft deelnemers aan de huisartsenstudie (circa 42000 receptorpunten), het vragenlijstonderzoek (circa 14000 receptorpunten) en het uitgebreide medisch onderzoek (ca 2500 receptorpunten). Per receptorpunt zijn alle 4 uurs-waarden gerapporteerd om inzicht te krijgen in kortdurende verhogingen in omgevingsconcentraties. Eventueel kunnen percentielwaarden met verschillende middelingstijden gekozen worden of ook kan een zogenaamde time-lag analyse worden uitgevoerd door de blootstelling te schuiven in de tijd, ten opzichte van de 
metingen van een (acuut) gezondheidseffect ((bijvoorbeeld met een 'time lag' van 4, 8 of 24 uur). Dergelijke analyses zijn in dit rapport buiten beschouwing gebleven. Voor de 14000 receptorpunten zijn de BVB- gegevens uit 2012 gebruikt omdat in die periode de korte gezondheidsvragenlijst is afgenomen. Voor de 2500 receptorpunten is gerekend met de BVB-gegevens uit 2015 omdat in die periode het VGO medisch onderzoek is uitgevoerd. Op basis van alle berekeningen is voor ieder receptorpunt de volgende informatie altijd beschikbaar:

o De jaargemiddelde waarden (of meer algemeen: de periode-gemiddelde waarden);

o Alle percentielwaarden $(50,75,90,95-99,99,1-99,9,99,97$ en 99,99) van 4uurgemiddelde waarden;

o De bijdragen van (15) diercategorieën;

o De bijdragen van 10 deeltjesgrootten.
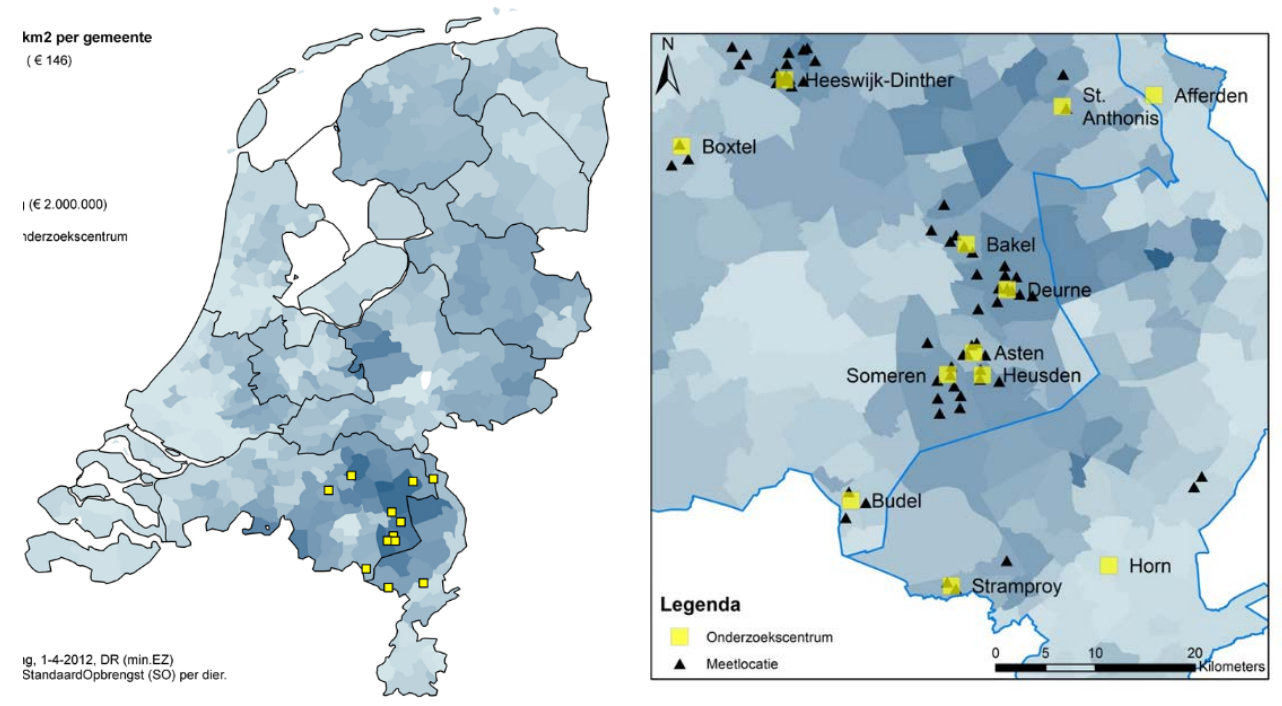

Figuur 4a en 4b. Onderzoekscentra VGO-gezondheidsonderzoek (geel) en meetlocaties (zwart) VGO- onderzoek luchtmetingen bij omwonenden.

\section{Presentatie endotoxineconcentratie op receptorpunten en middelingsduur}

Met de dispersie- of verspreidingsmodellen is de concentratie voor iedere 4-uur periode gedurende 365 dagen per jaar berekend. De keuze voor een 4-uurs gemiddelde is relatief arbitrair. Als met bijvoorbeeld 1-uursgemiddelde waarden zou worden gerekend neemt de kans op overschrijding van de grenswaarde van $\mathrm{EU} / \mathrm{m}^{3}$ toe omdat over kortere perioden omgevingsconcentraties luchtverontreiniging sterker variëren. Als met langere middelingstijden dan 4-uur wordt gerekend neemt de kans op overschrijding af omdat kortdurende variaties in omgevingsconcentraties worden uitgemiddeld.

Door over een periode van een jaar of langer te middelen wordt een jaargemiddelde of langetermijngemiddelde concentratie verkregen. Wanneer alle 4-uurgemiddelde concentraties op één punt worden gesorteerd ontstaat een concentratieverdeling die toont welke concentratieniveaus hoe vaak worden overschreden. Dit wordt beschreven door een zogenaamde percentielwaarde. Het $\mathrm{n}^{\mathrm{e}}$ percentiel wordt gedefinieerd als die concentratie die gedurende $\mathrm{n}$ procent van de tijd niet overschreden wordt. Het 99,5-percentiel is dus het concentratieniveau dat in 0,5\% van de tijd wordt overschreden. Om de kans op blootstelling te presenteren, moet ook voor een percentielwaarde worden gekozen: overschrijding van het 99-percentiel betreft 22 waarden van 4-uursperioden per jaar (2190 4-uursperioden per jaar, $2190 *(1-0,99))$; het 99,9-percentiel betreft slechts 2 waarden 
van 4-uursperioden per jaar; het 99,5-percentiel 10 waarden van 4-uursperioden per jaar. In de praktijk wordt meestal met meerjarige meteorologie doorgerekend. Daarmee is de keus voor het 99,5-percentiel een redelijk optimum voor 4-uursperioden: dat omvat dan 10 (1 jaar)-50 (5 jaar) waarden.

Validatie verspreidingsmodel berekende omgevingsconcentraties endotoxine Validatie van de met de verspreidingsmodel berekende omgevingsconcentraties endotoxine heeft plaatsgevonden door de in het VGO-onderzoek gemeten jaargemiddelde endotoxineconcentraties op 61 meetlocaties te vergelijken met de verspreidingsmodel berekende jaargemiddelde concentraties op deze 61 locaties. Per locatie is verspreidingsmodellering in tweevoud uitgevoerd; eenmaal waarbij warmte-emissie niet werd meegenomen in het verspreidingsmodel, andermaal waarbij warmte-emissie wel werd meegenomen in het verspreidingsmodel.

Als aanvullende analyse zijn gemeten endotoxineconcentraties gedurende kortere periodes (twee weken) vergeleken met de met verspreidingsmodellen berekende concentraties gedurende deze periodes. Hiermee wordt een combinatie van ruimtelijke variatie en variatie in de tijd in endotoxineconcentraties met dezelfde meetgegevens bekeken.

\section{Beschikbare VGO-meetgegevens}

De VGO-metingen bij omwonenden van veehouderijen zijn verricht in de periode mei 2014 tot en met december 2015. De details van de meetstrategie zijn in de VGO-rapportages en publicaties te vinden. ${ }^{3421}$ De locaties zijn voorafgaand aan het VGO-onderzoek zo gekozen dat sprake was van variatie in afstanden tot verschillende typen veehouderijen met verschillende diersoorten en variatie in dichtheid van veehouderijbedrijven rond de verschillende meetlocaties.

In het VGO-onderzoek is op 61 locaties op maximaal 5 meetmomenten (verspreid over de seizoenen) de tweeweekgemiddelde endotoxineconcentratie in $\mathrm{PM}_{10}$ stoffractie gemeten. Per meetlocatie is op basis van de metingen op die locatie de jaargemiddelde concentratie bepaald. De procedure hiervoor is uitgebreid beschreven en houdt rekening met de variatie over de tijd in concentratie zoals gemeten op het VGO-referentiemeetpunt (afstand tot dichtstbijzijnde veehouderij > $1200 \mathrm{~m}$, gelegen nabij een meetpunt van het nationale meetnet). ${ }^{21}$ Gedurende de VGO-meetcampagne zijn op dit VGO-referentiemeetpunt continue metingen uitgevoerd. Op nationale meetnetpunten worden geen endotoxine metingen uitgevoerd, vergelijkingen tussen endotoxine concentraties was dus niet mogelijk.

Omdat alle VGO-endotoxine metingen in de $\mathrm{PM}_{10}$ stoffractie zijn uitgevoerd, zijn de gemeten waardes vergeleken met de met het verspreidingsmodel berekende omgevingsconcentraties endotoxine in de $\mathrm{PM}_{10}$ fractie.

\section{Vergelijkingen verspreidingsmodel met VGO LUR-model}

Als onderdeel van het VGO-project is onderzocht of de blootstellingsmaten voor de aanwezigheid van veehouderij die in de VGO-studie zijn gebruikt (afstand tot dichtstbijzijnde bedrijf en dichtheid bedrijven in een buffer rond de woning) bleken samen te hangen met omgevingsconcentraties. Daartoe is de associatie onderzocht tussen de afstand van een meetlocatie voor stof en endotoxine tot het dichtstbijzijnde bedrijf en de dichtheid van bedrijven in een buffer rond de meetlocatie. Beide maten bleken samen te hangen met de endotoxineconcentratie (zie figuur $5 a$ en b). 

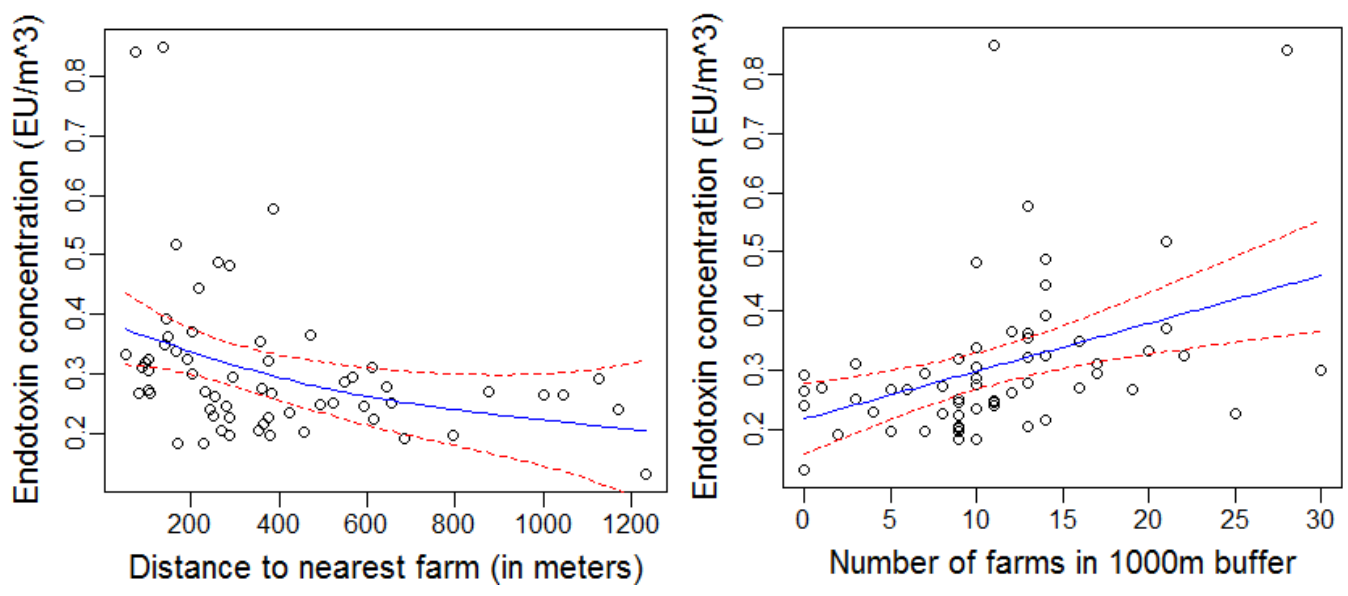

Figuur $\mathbf{5 a}$ en 5b. Relaties tussen omgevingsendotoxineconcentraties en afstand van de meetlocatie tot de dichtstbijzijnde veehouderij en het aantal veehouderijen in een buffer rond de meetlocatie, op basis van de resultaten voor de 61 VGO-meetlocaties.

Deze associaties verklaren ongeveer $15 \%$ in de variatie in de jaargemiddelde endotoxineconcentratie. Na de rapportage van het VGO-onderzoek zijn gedetailleerder analyses uitgevoerd en is informatie over de veehouderijbedrijven meegenomen in de analyse (diersoort, type bedrijf). Dit leverde sterkere verbanden op tussen de omgevingsendotoxineconcentratie en het uiteindelijke model, dit model verklaarde $64 \%$ variatie in endotoxineconcentratie. Dit type model, dat associaties tussen gemeten concentraties en informatie over landgebruik beschrijft, in dit geval de aanwezigheid van verschillende typen veehouderijbedrijven, wordt een 'Land Use Regression' of 'LUR' model genoemd. Met het ontwikkelde LUR-model zijn op basis van veehouderij kenmerken van de omgeving de jaargemiddelde endotoxine concentraties in de $\mathrm{PM}_{10}$ fractie voorspeld voor alle deelnemers aan het VGO-onderzoek. LUR-model berekeningen zijn uitgevoerd op de adressen van de deelnemers aan het VGO-gezondheidsonderzoek. Deze uitkomsten zijn vergeleken met de verspreidingsmodel berekende endotoxine concentraties in $\mathrm{PM}_{10}$ fractie op deze woonadressen.

\section{Resultaten}

\section{Sensitiviteitsanalyses BVB-gegevens}

Het gegevensbestand van ingenieursbureau Tauw met gedetailleerde informatie over de locaties van stallen bestaat uit een bestand van 326 stallen. Voor deze stallen is met de BVB-informatie en de Tauw informatie gerekend en het effect op de endotoxineconcentratie op 2090 receptorpunten $(10 \times 8 \mathrm{~km})$ nagegaan. In $90 \%$ van de gevallen is de relatieve fout die gemaakt wordt $20 \%$ of minder, door gebruik van BVB-gegevens in plaats van preciezer informatie over de locatie van stallen. Bij het $50 \%$ percentielpunt is de afwijking minder dan $10 \%$. Deze door BVB-gegevens gecreëerde onzekerheid is kleiner dan de gevoeligheid voor onzekerheden in de uittreesnelheid van lucht uit de stal (52\% toename gemiddeld over 2100 punten; indien uittreesnelheid verhoogd wordt van 1 naar $4 \mathrm{~m} / \mathrm{s}$ en $35 \%$ verhoging indien uittreesnelheid verhoogd wordt van 4 naar $8 \mathrm{~m} / \mathrm{s}$ ). De resultaten (op het 99,5 percentiel) tonen aan dat de onzekerheid in de BVB-gegevens niet resulteert in een onacceptabele afwijking in de eindresultaten.

\section{Sensitiviteitsanalyses ruwheid en meteorologie}

In een sensitiviteitsanalyse is voor de ruwheidsparameters gerekend met een gebied van $2 \times 2 \mathrm{~km}^{2}$ in plaats van $5 \times 5 \mathrm{~km}^{2}$ om het effect van verfijning van de ruwheidsinformatie te kwantificeren. Het 
resultaat is gemiddeld een $7 \%$ verlaging in endotoxineconcentratie. Bij $70 \%$ van de receptorpunten was het verschil $10 \%$ of minder.

De keuze voor een bepaalde meteo-periode bepaalt mede de endotoxineconcentratie op een gegeven receptorpunt. Omdat een receptorpunt in een bepaalde windrichting, gezien vanaf de bron ligt, kan de berekende concentratie tot $10 \%$ variëren, afhankelijk van de meteo-periode (zie figuur 6).

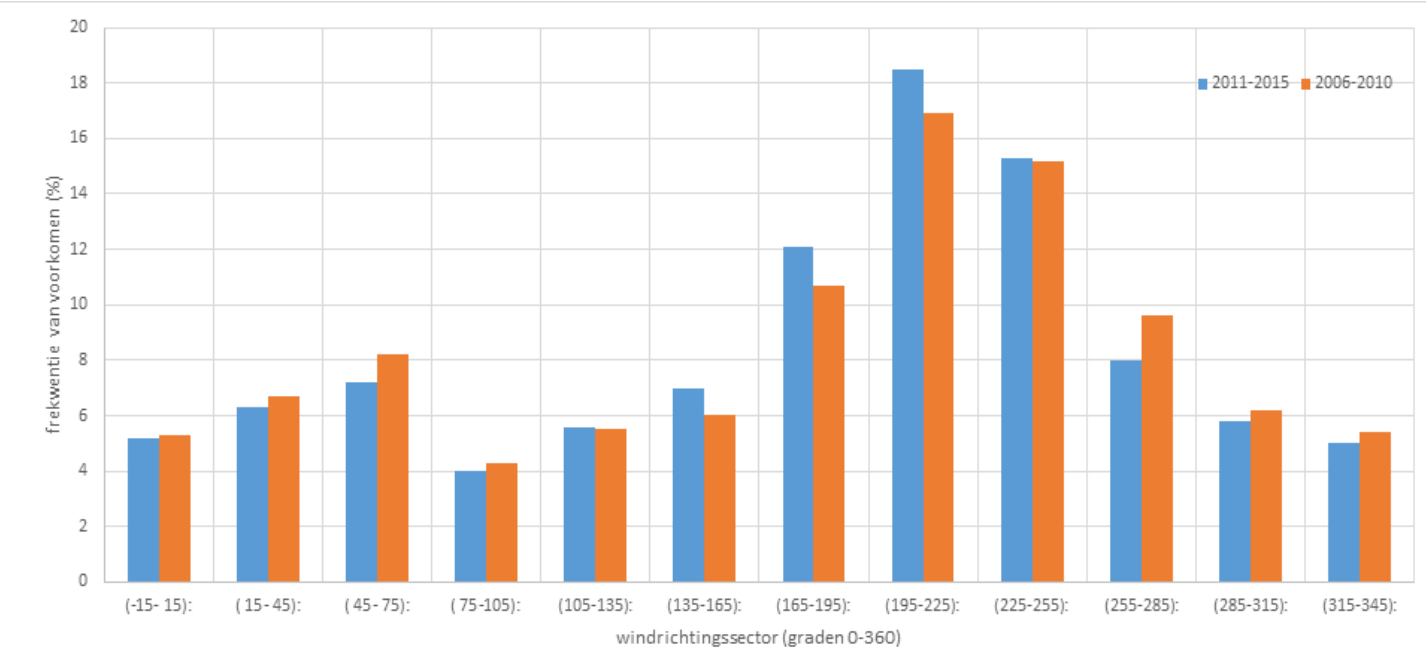

Figuur 6. Effect van de keuze voor verschillende 5 jaar periodes voor de meteorologische gegevens.

Sensitiviteitsanalyse voor het aantal bronnen rond een receptorpunt

Een reductie tot 70 bronnen bleek nog goede uitkomsten te geven (zie figuur 7). Afhankelijk van de doelstelling van een berekening is ervoor gekozen om met 70, 80, 100 of 250 bronnen te rekenen rond een receptorpunt. Voor het maken van de eerste kaarten van endotoxineconcentraties is voor 80 bronnen gekozen. Voor de validatie, waarbij modelschattingen zijn vergeleken met endotoxine metingen die beschikbaar waren uit de VGO-studie, is voor 250 bronnen gekozen om een zo exact mogelijke schatting te produceren. 


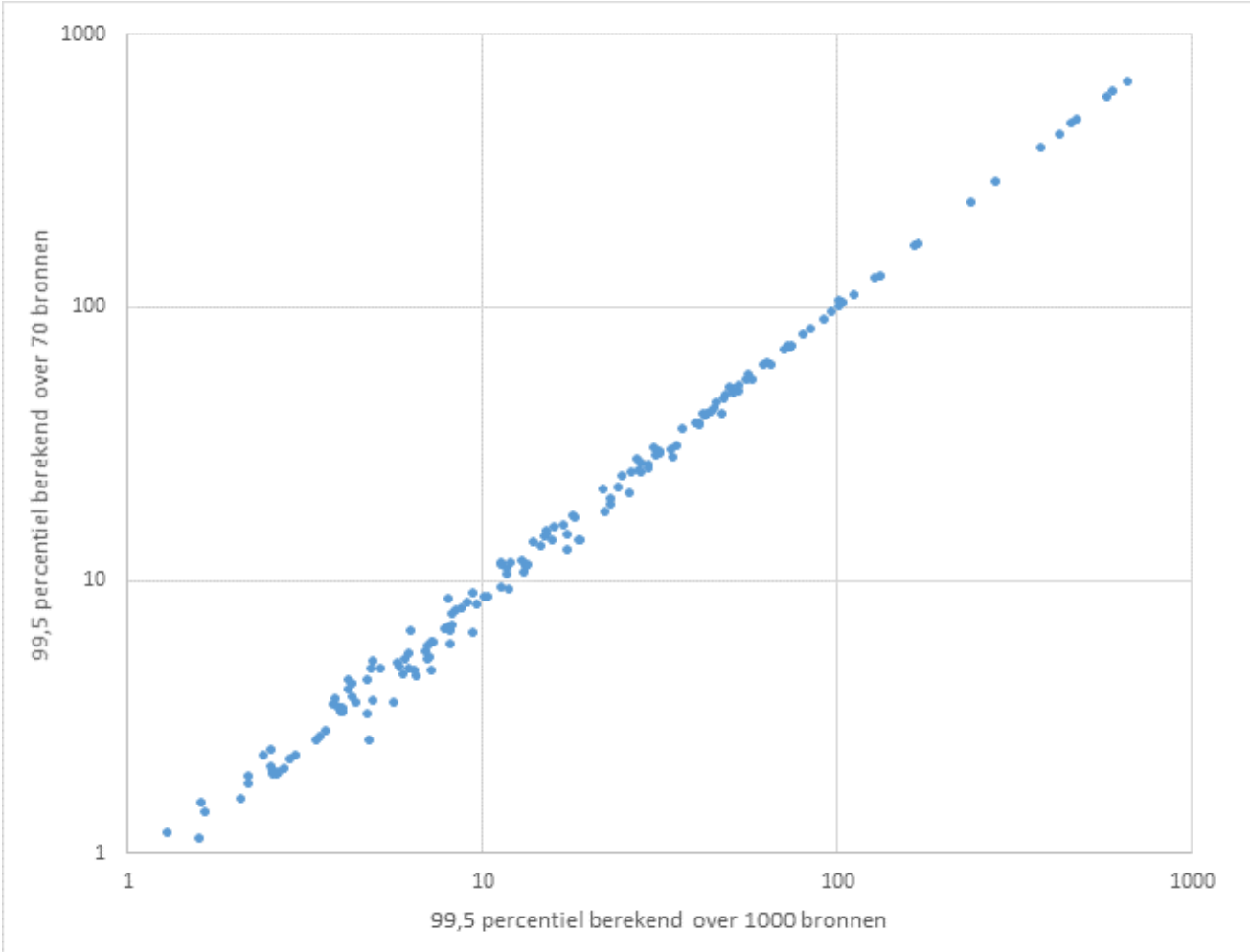

Figuur 7. Vergelijking berekende 99,5 percentielwaarden bij gebruik van 70 bronnen ten opzichte van gebruik van 1000 bronnen in de berekeningen.

Validatie met VGO-meetgegevens

Vergelijkingen tussen $\mathrm{PM}_{10}$ massa concentraties gemeten op het VGO-referentiepunt en het dichtbijgelegen nationale meetnetpunt laten een hoge mate van overeenkomst zien (Pearson correlatie 0,924; zie figuur in Appendix 2). In een selectie van de monsters uit de VGO studie ( $n=30)$ is herhaaldelijk de endotoxineconcentratie geanalyseerd in het laboratorium. De resultaten lieten een hoge mate van overeenkomst en een beperkte mate van variatie zien tussen de uitslagen per monster (correlatie $=0.95$, variatiecoëfficiënt $=13.7 \%$ ). De hoge mate van overeenkomst in $\mathrm{PM}_{10}$ concentraties tussen het VGO-referentiepunt en landelijkmeetnetstation en daarnaast de beperkte analytische variatie in de endotoxineanalyse wijzen op een degelijke uitvoering van de metingen en hoge betrouwbaarheid van de uitslagen.

In de validatiestudie worden de gemeten concentraties als gouden standaard beschouwd. De validatiestudie heeft een paar belangrijke bevindingen opgeleverd. Allereerst is gebleken dat de modellen zonder warmte emissie de concentratie endotoxine op leefniveau gemiddeld ongeveer een factor twee-en-een-half overschatten. Warmte emissie leidt na het verlaten van stof en endotoxine houdende lucht uit de stal tot verdere stijging van die lucht waardoor deeltjes over een groter gebied worden verspreid. Dit leidt tot lagere concentraties op relatief kortere afstanden. De associatie tussen de met het verspreidingsmodel berekende (zonder/met warmte-emissie) concentraties en gemeten endotoxineconcentraties zijn hieronder weergegeven (figuur $8 a+b$ ). 

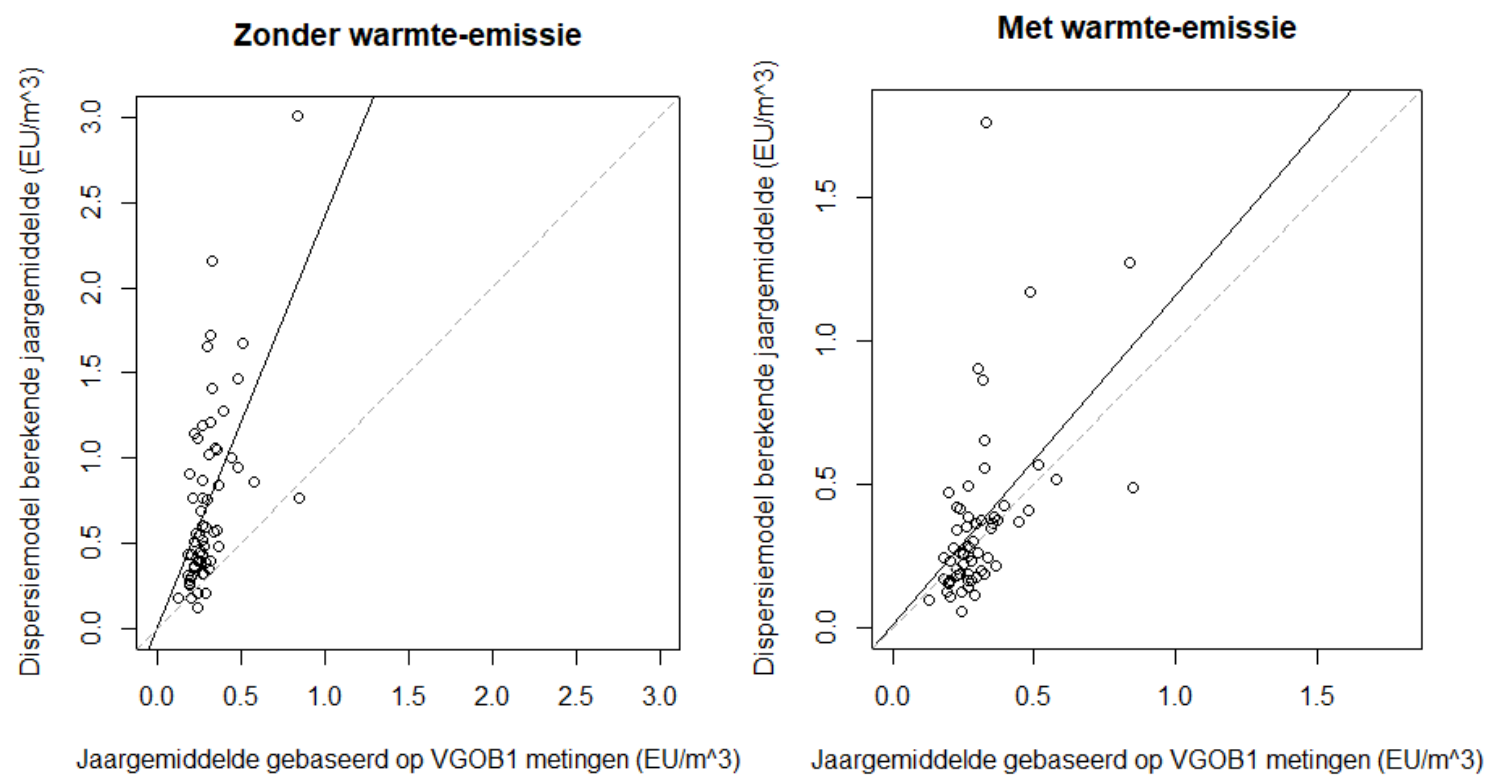

Figuur 8a en $8 \mathrm{~b}$. Correlatie tussen de jaargemiddelde gemeten endotoxineconcentratie en middels verspreidingsmodellen berekende jaargemiddelde endotoxineconcentratie voor de 61 VGOmeetlocaties, zonder (links; correlatie $p=0,59$ ) en met (rechts; correlatie $p=0,51$ ) warmte-emissie.

De figuren laten zien dat wanneer warmte-emissie niet wordt meegenomen in het verspreidingsmodel de concentraties met ongeveer een factor twee-en-half overschat worden. Wanneer warmte-emissie wel wordt meegenomen komen de berekende concentraties gemiddeld genomen goed overeen, voorspelde waardes komen duidelijk dichter in de buurt van daadwerkelijk gemeten waardes. Dit bevestigt wat op theoretische gronden verwacht kan worden wanneer er sprake is van warmte-emissie. Naar aanleiding van de resultaten van deze validatiestudie, is gekozen om in de vervolganalyses warmte-emissie mee te nemen in de verspreidingsmodellering. In het huidige beleid voor geur en fijnstof wordt de warmte-emissie niet meegenomen. Dit suggereert dat de huidig gebruikte modellen de concentratie in de buitenlucht op korte afstand van veehouderijbedrijven overschatten. Rekenen met warmte-emissie leidt tot grotere verdunning van de emissie en verspreiding over een groter gebied. 


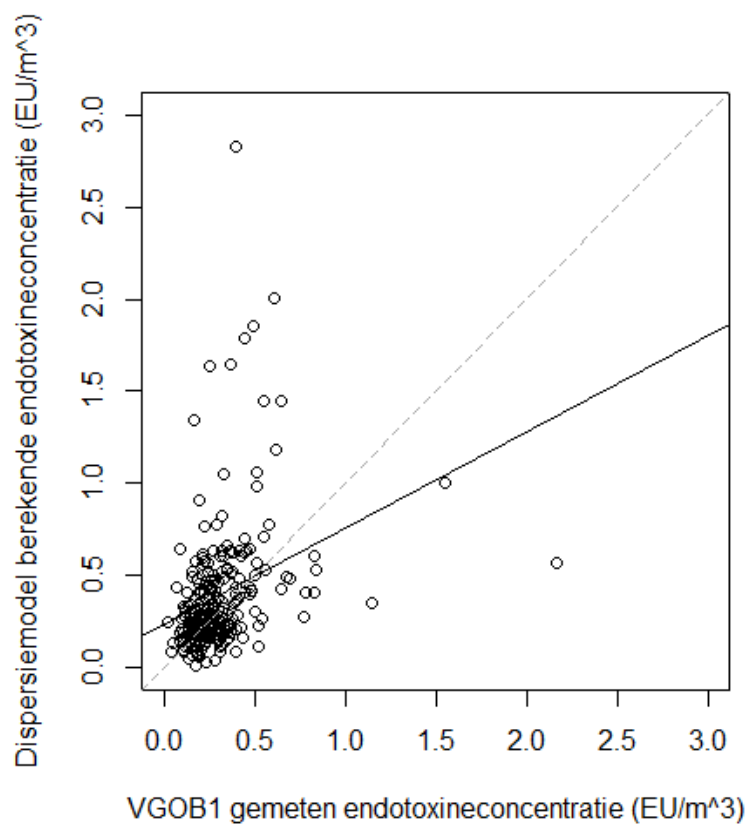

Figuur 9. Correlatie tussen de tweeweeks-gemiddelde gemeten endotoxineconcentratie en middels verspreidingsmodel (warmte-emissie meegenomen) berekende tweeweeks-gemiddelde endotoxineconcentratie voor de herhaalde metingen op de 61 VGO-meetlocaties (correlatie = $0,32)$.

Figuur 9 geeft de correlatie weer tussen de gemeten tweeweeks gemiddelde endotoxineconcentratie en de voor de betreffende meetperiode gemodelleerde tweeweeks gemiddelde concentratie. De figuur is gebaseerd op de herhaalde individuele metingen op de 61 locaties ( $n=238$ ), elke meting had een duur van twee weken. Deze plot omvat zowel het vermogen van het verspreidingsmodel om verschillen tussen locaties te voorspellen als verschillen over de tijd. Wat opvalt is dat het verband tussen gemeten concentraties en berekende concentraties minder sterk is ten opzichte van de vergelijking met betrekking tot verschillen tussen locaties (jaargemiddeldes), het model lijkt minder goed in staat temporele variatie in te schatten dan ruimtelijke variatie. Dit wordt bevestigd wanneer gekeken wordt naar de correlatie per meetlocatie tussen gemeten concentraties gedurende 14 dagen en berekende concentraties, waarbij het gemiddelde van al deze correlaties ( $n=61$, immers één correlatie per locatie) uitkomt op 0,35 . Er is overigens wel sprake van een aanzienlijke variatie in correlaties voor de verschillende locaties, dit heeft deels te maken met het beperkte aantal observaties per locatie (gemiddeld 4 metingen per locatie), maar kan ook wijzen op lokale afwijkingen tussen werkelijke en gemodelleerde concentraties. Op het referentiepunt zijn meer, in totaal 25 , herhaalde metingen uitgevoerd elk gedurende 14 dagen (figuur 10). De vergelijking tussen op het referentiepunt gemeten endotoxine concentraties en met het model berekende endotoxine concentraties laten eveneens een matige correlatie zien (correlatie $=0,27$ ). 


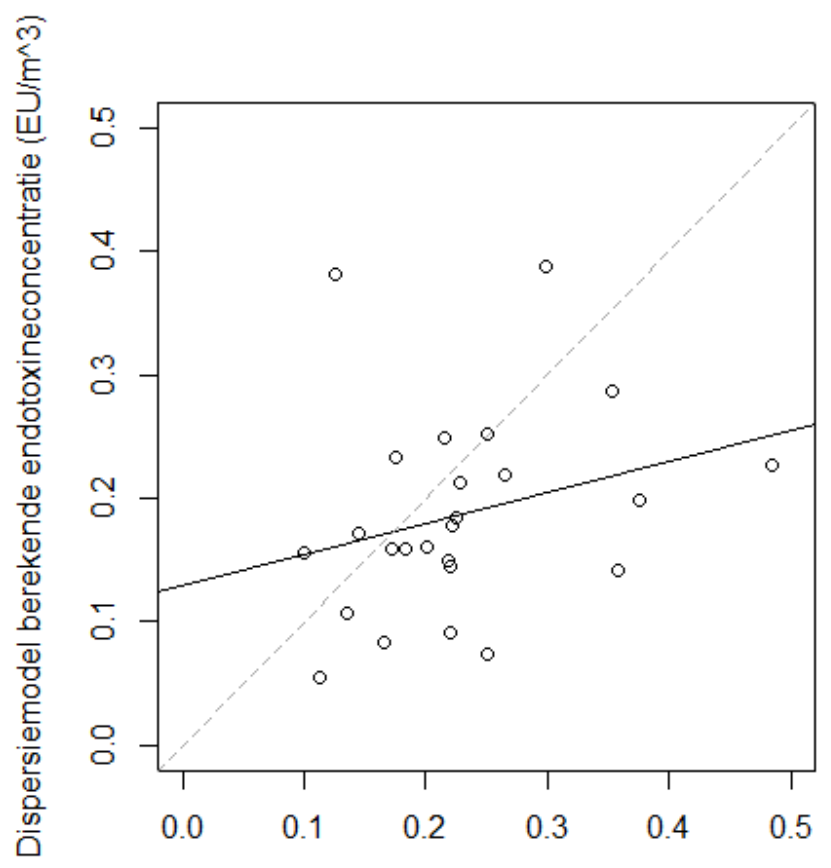

VGOB1 gemeten endotoxineconcentratie $\left(E U / m^{\wedge} 3\right)$

Figuur 10. Correlatie tussen de tweeweeks-gemiddelde gemeten endotoxine concentratie en middels verspreidingsmodel (warmte-emissie meegenomen) berekende tweeweeks-gemiddelde endotoxineconcentratie voor de herhaalde metingen op het VGO-referentiepunt (correlatie = 0,27).

Deze resultaten duiden erop dat het verspreidingsmodel minder goed in staat is de verschillen in concentraties luchtverontreiniging over de tijd te voorspellen dan verschillen in concentraties tussen locaties. Dit wordt ten dele verklaard door de korte middelingsduur waarover variatie over de tijd is voorspeld. In geval van kortere periodes zijn voorspellingen in de regel minder accuraat. Daarnaast kunnen beperkingen in de beschikbare gegevens een rol spelen (onzekerheden in en aannames bij afleiding van emissiefactoren, berekeningen op basis van vergunde dieraantallen, bronvariatie voor bepaalde diersectoren in verband met cyclische processen) (zie Appendix 1).

Vergelijkingen met LUR-model berekende endotoxine concentraties

De met LUR-modellen voorspelde concentraties zijn vergeleken met de met verspreidingsmodellen berekende endotoxine concentraties zowel op de 61 meetlocaties als op het woonadresniveau van de deelnemers aan het VGO-gezondheidsonderzoek. De correlatie tussen endotoxineconcentraties volgens beide methoden berekend voor zowel de meetlocaties als voor de woonadressen is hoog. Beide modellen voorspellen voor de overgrote meerderheid van VGO-deelnemers jaargemiddelde endotoxineconcentraties lager dan $1 \mathrm{EU} / \mathrm{m}^{3}$ (percentage van VGO medisch onderzoek deelnemers en percentage van korte vragenlijst deelnemers; respectievelijk $99,08 \%$ en $99,53 \%$ voor verspreidingsmodel en $99,88 \%$ en $99,86 \%$ voor het LUR-model). Het aantal en de hoogte van de endotoxineconcentratie-maxima liggen wat hoger voor voorspellingen met het verspreidingsmodel. Dat is niet vreemd, de verspreidingsmodellen nemen namelijk alle veehouderijbronnen mee in de analyse terwijl het LUR-model voorspelt op basis van een selectie van veehouderijkenmerken van de omgeving. Voorspellingen van absolute niveaus zullen dan uiteen gaan lopen op locaties met erg hoge dierdichtheden in de omgeving en meerdere diersoorten. Dit is ook terug te zien in de voorspellingen op woonadresniveau; hoe hoger het aantal woonadressen dat wordt meegenomen, 
hoe groter de kans op inclusie van uitzonderlijke locaties. Het ruimtelijk oplossend vermogen van verspreidingsmodellen lijkt op basis van deze resultaten wat hoger te liggen, maar opgemerkt dient te worden dat er geen metingen beschikbaar zijn om deze voorspelde hogere waardes te verifiëren dan wel als modeloverschatting aan te merken.

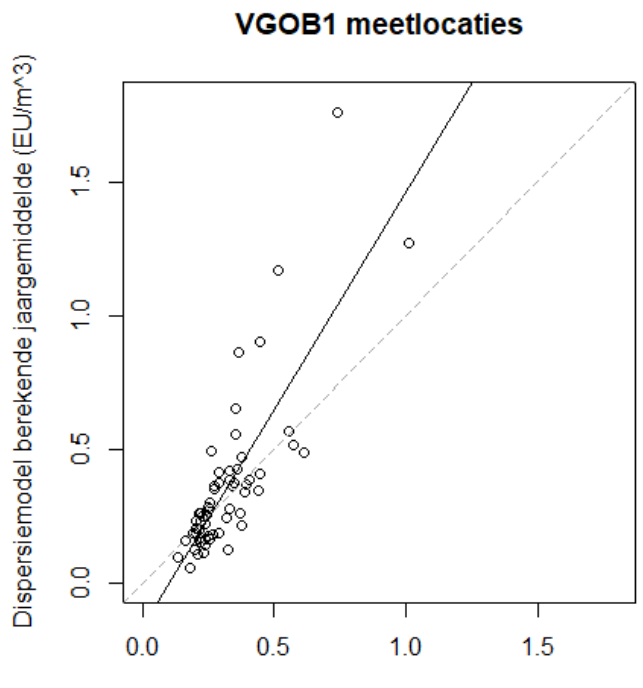

LUR model berekende jaargemiddelde $\left(\mathrm{EU} / \mathrm{m}^{\wedge} 3\right)$

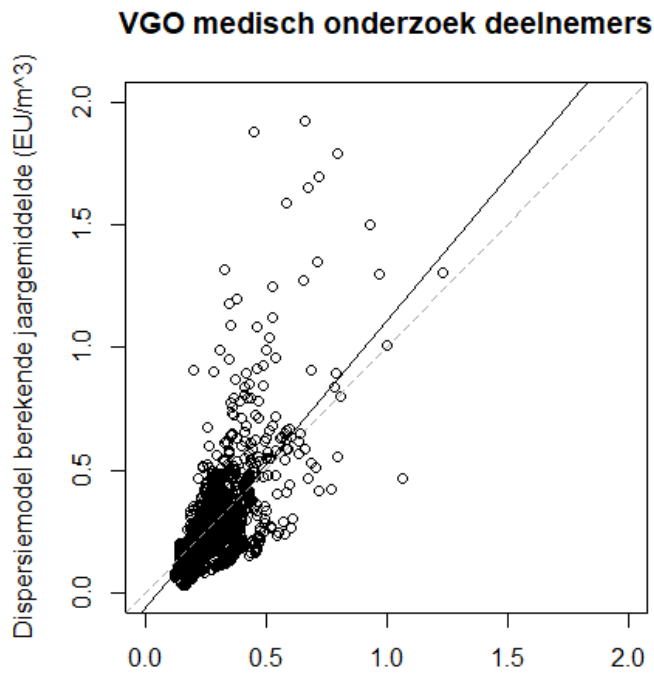

LUR model berekende jaargemiddelde $\left(E U / \mathrm{m}^{\wedge} 3\right)$

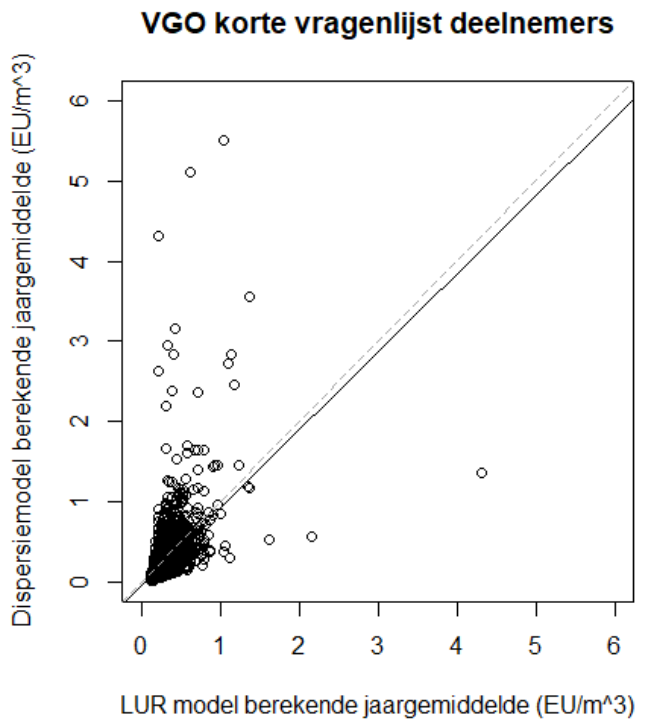

Figuur 11a-11c. Correlatie tussen de 'Land Use Regression' (LUR)-modelpredicties van de jaargemiddelde endotoxineconcentratie en middels verspreidingsmodel berekende jaargemiddelde endotoxineconcentratie voor de 61 VGO-meetlocaties, 2494 VGO-deelnemers aan het medisch onderzoek en de 12117 VGO-deelnemers aan de korte vragenlijst.

Hybride modellen

Aanvullende analyses laten zien dat het combineren van het verspreidingsmodel met het LUR-model geen duidelijke meerwaarde heeft. Dit is verkend door middel van het opbouwen van een zogenaamd hybride model, een combinatie van een verspreidingsmodel met een LUR-model. Het 
toevoegen van verspreidingsmodel voorspelde endotoxineconcentraties aan het bestaande LURmodel leidde niet tot verbeterde modelresultaten. Dat het combineren van modellen geen duidelijke verbetering oplevert, hangt samen met de hoge mate van overeenkomst in uitkomsten, maar ook met het feit dat het door de modellen onverklaarde deel van variatie in metingen sterk overlappend is. Dat beide modellen dezelfde inputgegevens over dieraantallen gebruiken ligt hier deels aan ten grondslag. In de vergunningsgegevens is geen informatie opgenomen over variatie in de emissie over de tijd voor diersoorten waar dat wel relevant voor is (pluimvee) en ook de variatie in emissie tussen bedrijven, waarvan bekend is dat die aanzienlijk kan zijn door verschillen in bouw, maar ook bedrijfsmanagement, is in beide gevallen onbekend. Naar verwachting zou juist informatie over deze emissie-gerelateerde aspecten tot aanzienlijke verbeteringen in de voorspelde concentraties kunnen leiden. Daarnaast is verkend of het toevoegen van veehouderijkenmerken van de omgeving een toegevoegde waarde had op de door het verspreidingsmodel voorspelde endotoxineconcentraties als basis. Toevoegen van pluimvee-gerelateerde kenmerken van de omgeving bleek meerwaarde op te leveren, dit kan duiden op een minder accurate emissie-inschatting van deze typen bedrijven ten opzichte van de andere typen bedrijven. Aanvullende emissiemetingen, waarbij een grotere diversiteit aan pluimveebedrijven wordt meegenomen, of betere karakterisering van bedrijven en de effecten van beheersmaatregelen op de endotoxine-emissie, kunnen hier meer inzicht in geven.

\section{Regionale endotoxine concentraties; niveaus en ruimtelijke verdeling}

In de vervolganalyses is het effect van warmte-emissie in de verspreidingsmodellering meegenomen. Voor de 14000 receptorpunten van deelnemers aan het VGO-vragenlijstonderzoek geldt dat 2,3\% van de receptorpunten een 99,5 percentielwaarde van meer dan $30 \mathrm{EU} / \mathrm{m}^{3}$ heeft. De 98 percentielwaarde is meer dan $30 \mathrm{EU} / \mathrm{m}^{3}$ voor $1.5 \%$ van de 14000 receptorpunten (Figuur 12a en b). Het jaargemiddelde correleert goed met het 99,5 percentiel (zie figuur 13 voor de gepaarde correlatie). De weergave in deze figuur op logaritmische assen geeft een beter beeld van de spreiding in de berekende waarden. Door log-transformatie wordt meer nadruk gelegd op de lagere waarden. De figuur toont aan dat over het gehele bereik van berekende waarden de helling van de regressielijn hetzelfde is. Als gevolg hiervan kan het 99,5 percentiel relatief betrouwbaar afgeleid worden uit de jaargemiddelde waarden.

Uit de resultaten verkregen voor de 310000 receptorpunten blijkt het aantal punten met een 99,5 percentielwaarde hoger dan $30 \mathrm{EU} / \mathrm{m}^{3} 1,8 \%$ te zijn (niet gepresenteerd). Dit betekent dat bijna $2 \%$ van het oppervlak van Oostelijk Noord-Brabant boven de door de Gezondheidsraad voorgestelde grenswaarde voor endotoxine van $30 \mathrm{EU} / \mathrm{m}^{3}$ ligt. Deze receptorpunten zijn immers regelmatig over het oppervlak verdeeld met onderlinge afstanden van $125 \mathrm{~m}$. 

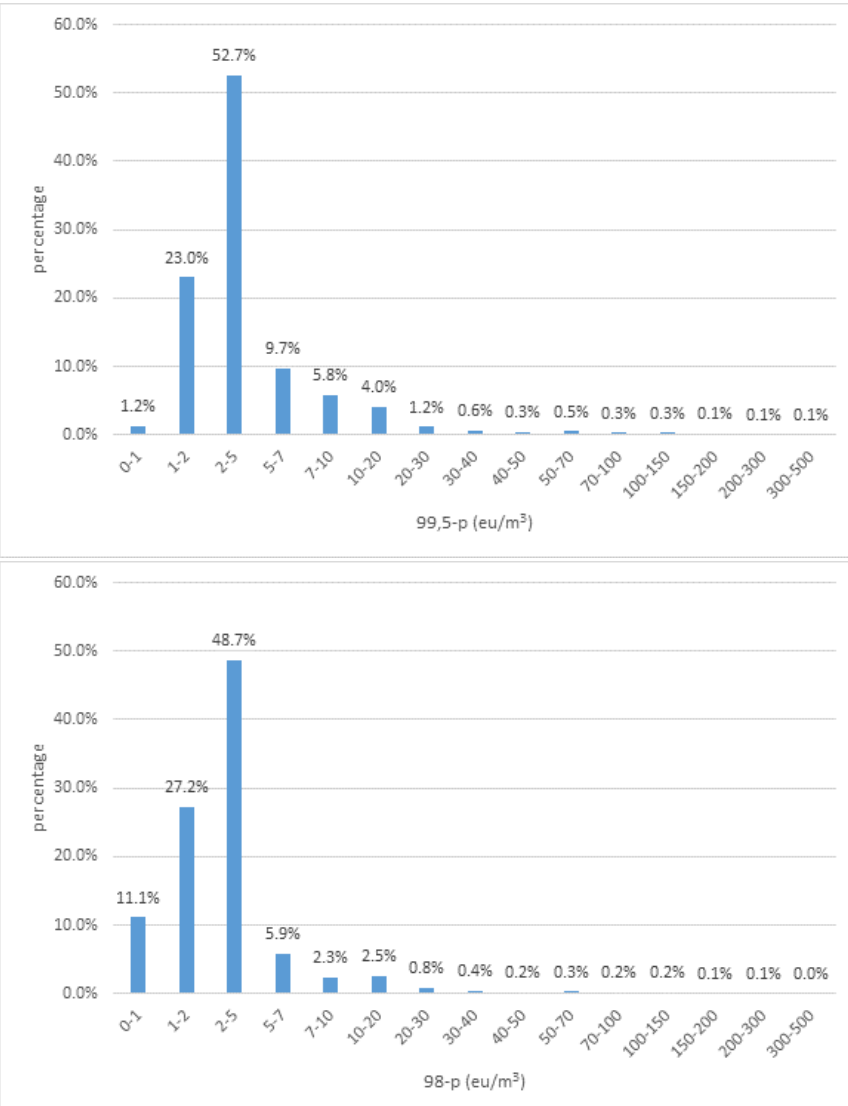

Figuur 12a en 12b. Frequentieverdeling van de berekende 99,5 en 98 -percentielwaarden voor de 14000 receptorpunten. Op de $X$-as staan de intervallen van respectievelijk de 99,5 - of 98percentielwaarden: 1: loopt van $0-1 \mathrm{EU} / \mathrm{m}^{3} ; 2$ : van $1-2 \mathrm{EU} / \mathrm{m}^{3}$; 3: van $2-5 \mathrm{EU} / \mathrm{m}^{3}$ etc.

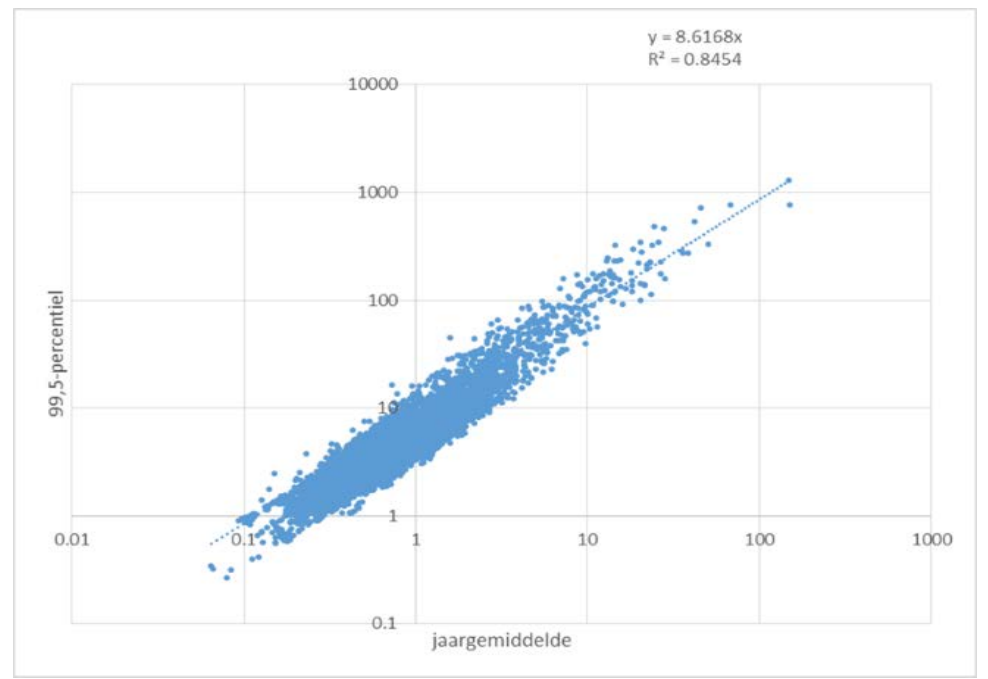

Figuur 13. Correlatie tussen de berekende jaargemiddelde concentratie en 99,5 percentiel waarde voor de circa 14000 receptorpunten.

Alle deeltjesfracties dragen bij aan de endotoxineconcentraties op de receptorpunten (zie figuur 14). De variatie tussen individuele receptorpunten in de bijdrage van de deeltjesfracties is groot met tot tientallen procenten verschil in bijdrage. Deze variatie is het grootst voor de grotere deeltjes (tot 
maximaal circa $40 \%$ bijdrage voor individuele receptorpunten). Gemiddeld dragen alle deeltjesfracties tussen de $5 \%$ en $15 \%$ bij aan de endotoxineconcentratie op een receptorpunt, waarbij deeltjes met een diameter tussen de 1 en $6 \mu \mathrm{m}$ gemiddeld het meest bijdragen (15\%).

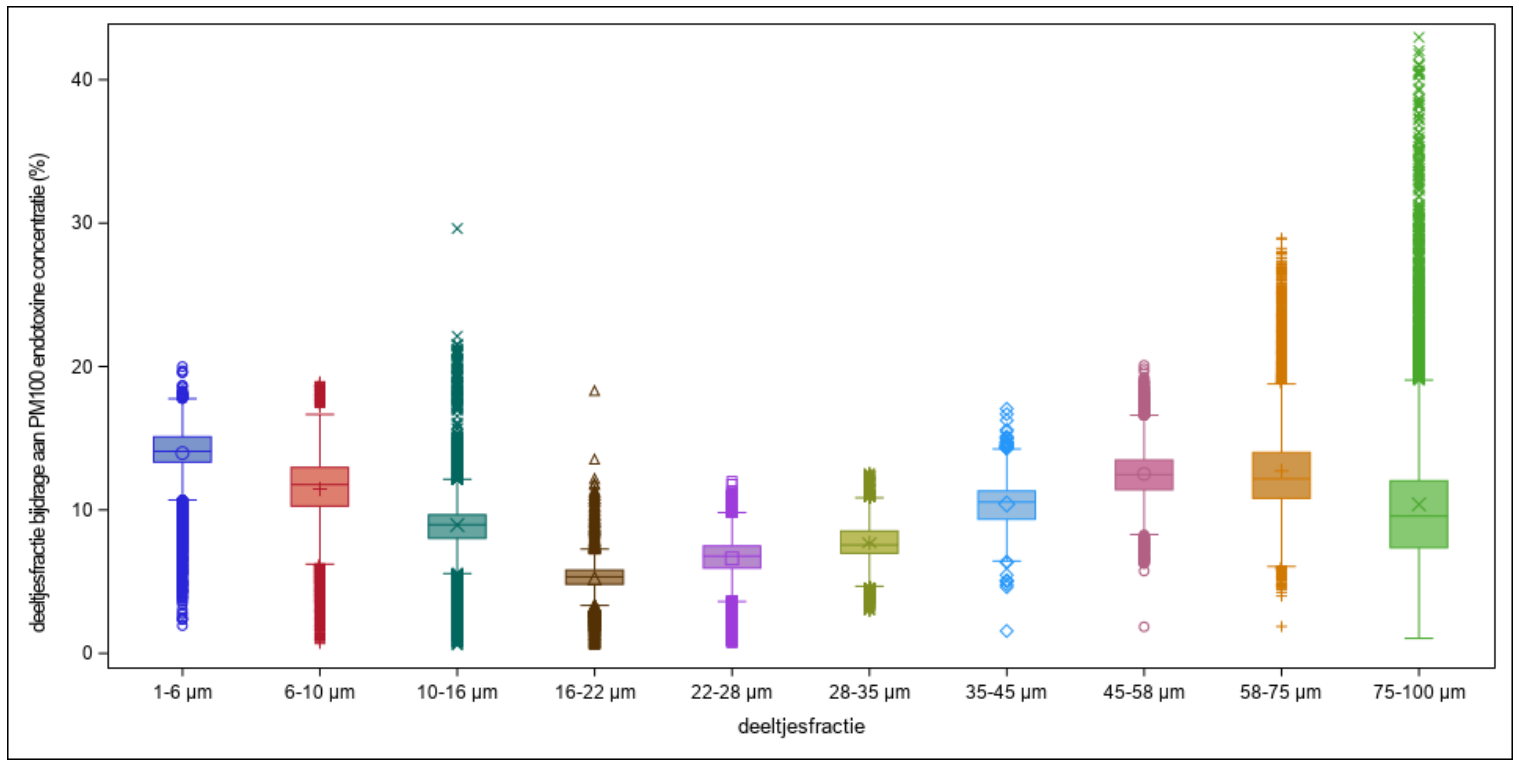

Figuur 14. Relatieve bijdrage van verschillende deeltjesfracties aan de endotoxineconcentratie voor de circa 14000 receptorpunten.

Voor het VGO-gebied van circa $70 \times 70 \mathrm{~km}^{2}$ is een contourplot gemaakt van alle 99,5 percentielwaarden, en een tweetal uitsnedes van deze figuur voor het oostelijk deel van het gebied rond de woonkernen Asten en Someren en Venray (figuur 15). Op meerdere plaatsen is te zien dat daar waar meerdere bedrijven aanwezig zijn en sprake is van hoge bedrijfsdichtheden, emissiecontouren rond bedrijven samensmelten tot grotere gebieden. Duidelijk is dat gebieden met hoge percentielwaarden meestal ruimtelijk zeer begrensd zijn ('zeer lokaal') en nooit in de centra van dorpen en steden liggen. Gebieden met hoge percentielwaarden omvatten wel af en toe woonkernen, een voorbeeld hiervan is te zien in figuur $15 \mathrm{c}$.

Ook is gekeken naar de bijdrage van de vier diersoorten (paarden, pluimvee, runderen, varkens) aan de concentraties endotoxine op de circa 14000 receptorpunten in een ruimtelijke figuur voor deze receptorpunten (figuur 16), en kwantitatief (figuur 17 en 18). Ruimtelijke patronen zijn verschillend voor de diersoorten. De bijdrage van paarden en runderen is in het algemeen klein $(<20 \%)$ maar kan voor een beperkt aantal locaties ook zeer hoog zijn (>80\%), deze punten worden gekenmerkt door een oranje/rode kleur in de figuur. 


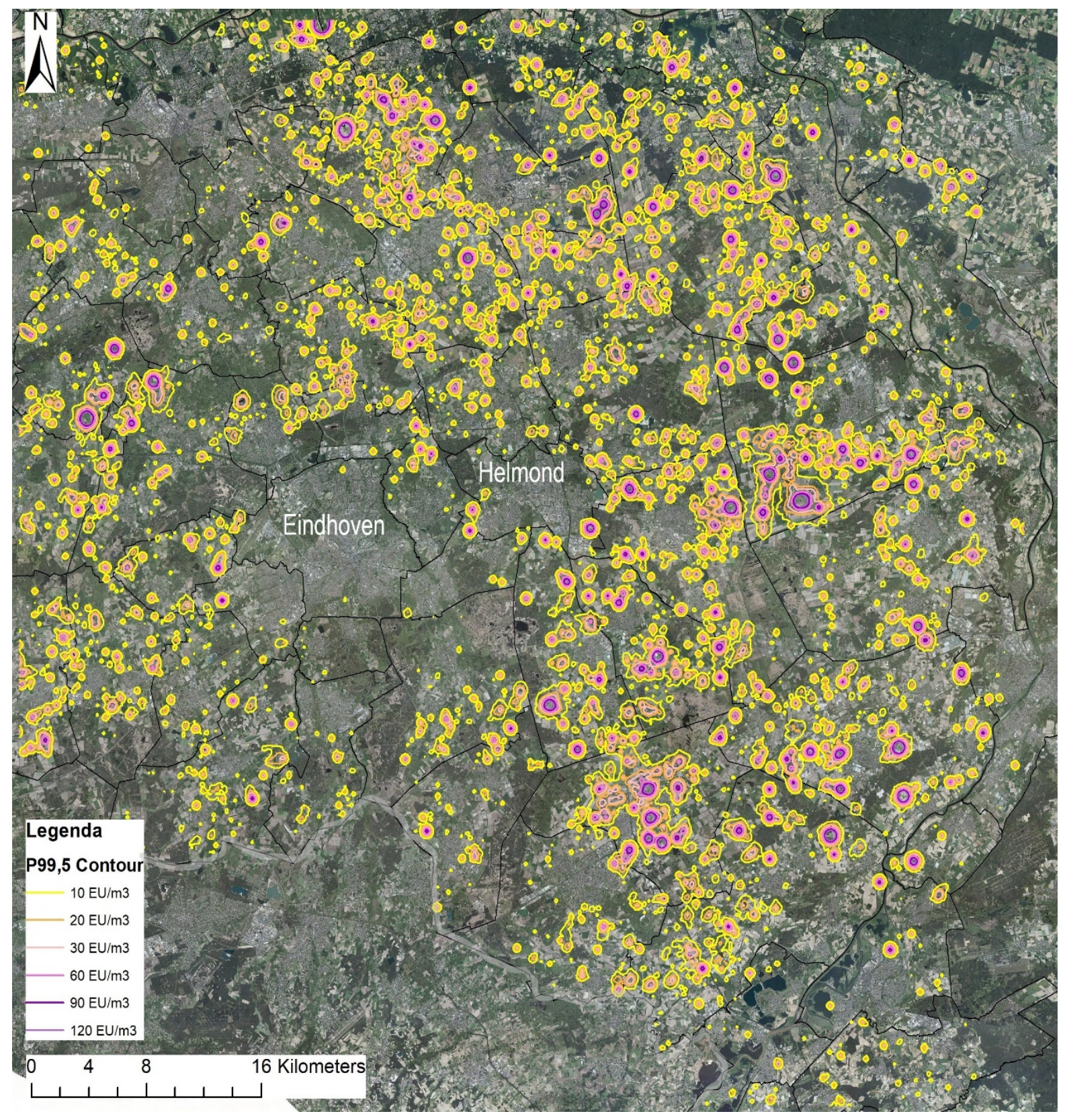

Figuur 15a. Contourplot van 99,5p endotoxine waarden in het circa $70 \times 70 \mathrm{~km}^{2}$ gebied waarin ook de VGO-studie heeft plaatsgevonden. De contourlijnen representeren waarden van 10, 20, 30, 60, 90 en $120 \mathrm{EU} / \mathrm{m}^{3}$. De grens van Nederland is weergegeven met een grijze lijn. 

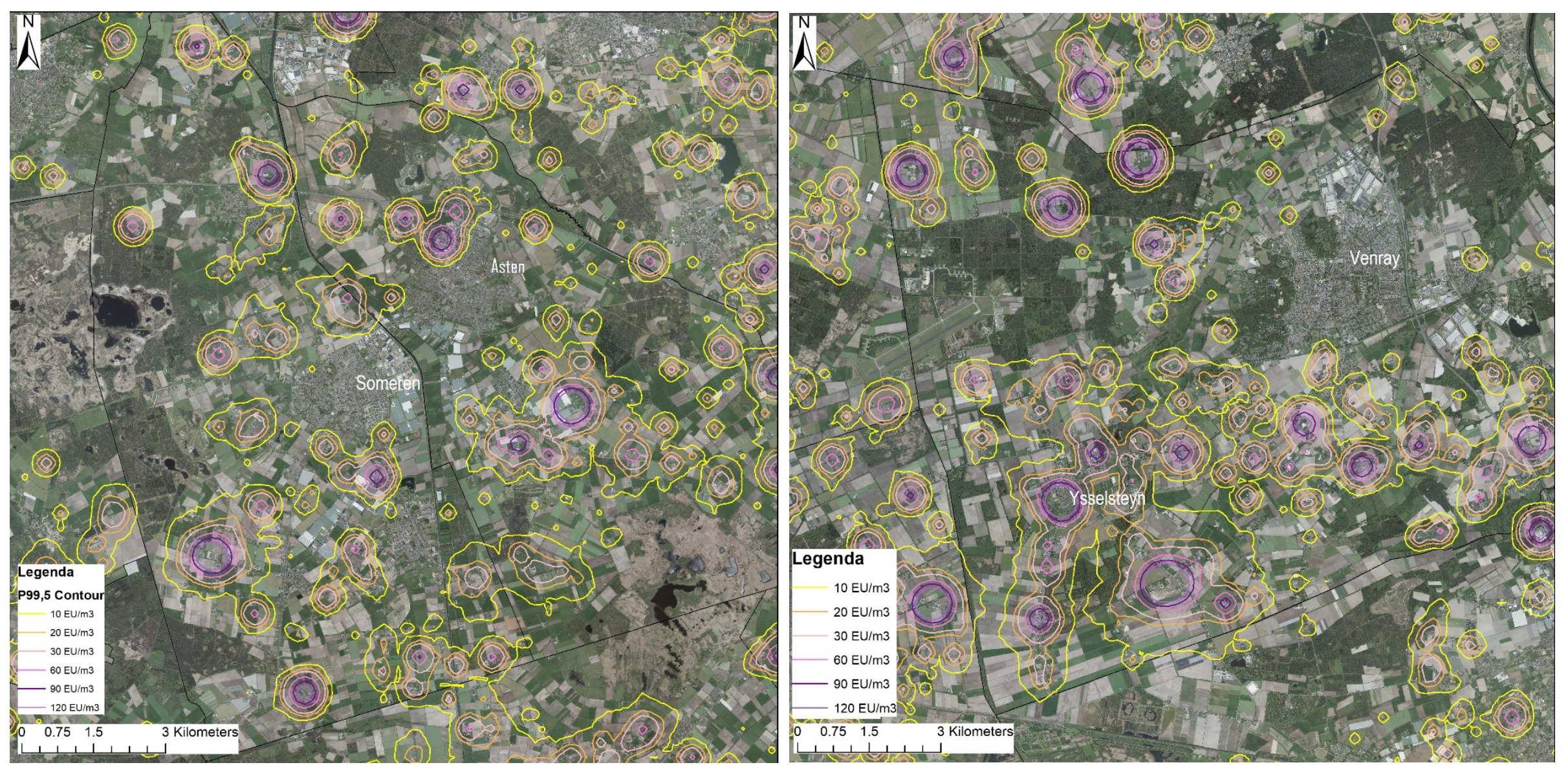

Figuur 15b en 15c. Contourplot van 99,5p endotoxine waarden in kleinere meer ingezoomde uitsnedes rond Asten en Someren (links) en Venray (rechts). De contourlijnen representeren waarden van $10,20,30,60,90$ en $120 \mathrm{EU} / \mathrm{m}^{3}$. 
Voor varkens en pluimvee is het ruimtelijk beeld anders, deze diersoorten dragen in het algemeen beiden meer bij aan de endotoxine concentratie (percentages tussen 40 en $>80 \%$ ), hoe roder de kleur hoe meer bijdrage van de diersoort. Grootschalige ruimtelijke verschillen lijken met name aanwezig voor pluimvee, waarbij de invloed van hiervan duidelijk meer en over een uitgbreider gebied aanwezig is in zuid-oostelijk Noord-Brabant en in Noord Limburg, dan in andere delen van het onderzochte gebied. De bijdrage van varkens lijkt in het algemeen groter dan voor de andere diercategorieën.

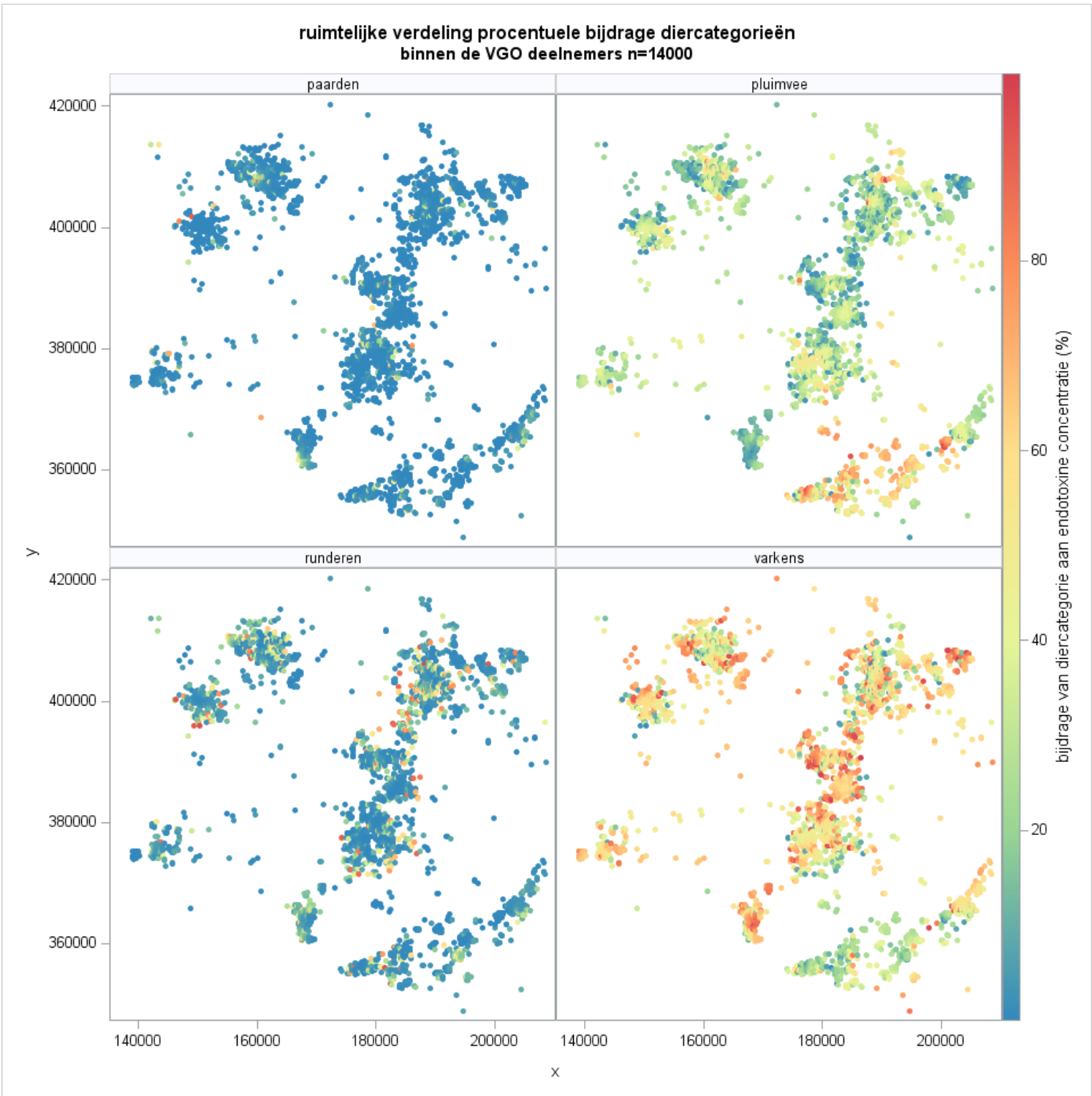

Figuur 16. Ruimtelijke weergave van de bijdrage van de belangrijkste diersoorten aan de endotoxineconcentratie op de circa 14000 receptorpunten. Naarmate de hoogte van de bijdrage varieert de kleur van blauw (lage bijdrage $<10 \%$ ) tot rood (hoge bijdrage $>90 \%$ ).

Ook wanneer de bijdrage meer kwantitatief beschouwd wordt blijken alle diersoorten bij te dragen, maar de verschillen tussen diersoorten en de subtypes hierbinnen zijn groot (figuur 17). Varkens hebben de grootste bijdrage (gemiddeld rond de 60\%) over alle receptorpunten, gevolgd door pluimvee (gemiddeld rond de $40 \%$ ) en de kleinste gemiddelde bijdrage is voor runderen. De gemiddelde bijdrage is de resultante van emissie door een diersoort (per dier), het gemiddeld aantal dieren op een bedrijf, en het aantal dieren in de regio en de afstand van de bedrijven tot de woning. 
Uit de figuur blijkt dat voor individuele receptorpunten de relatieve bijdrage van de diersoorten sterk kan verschillen.

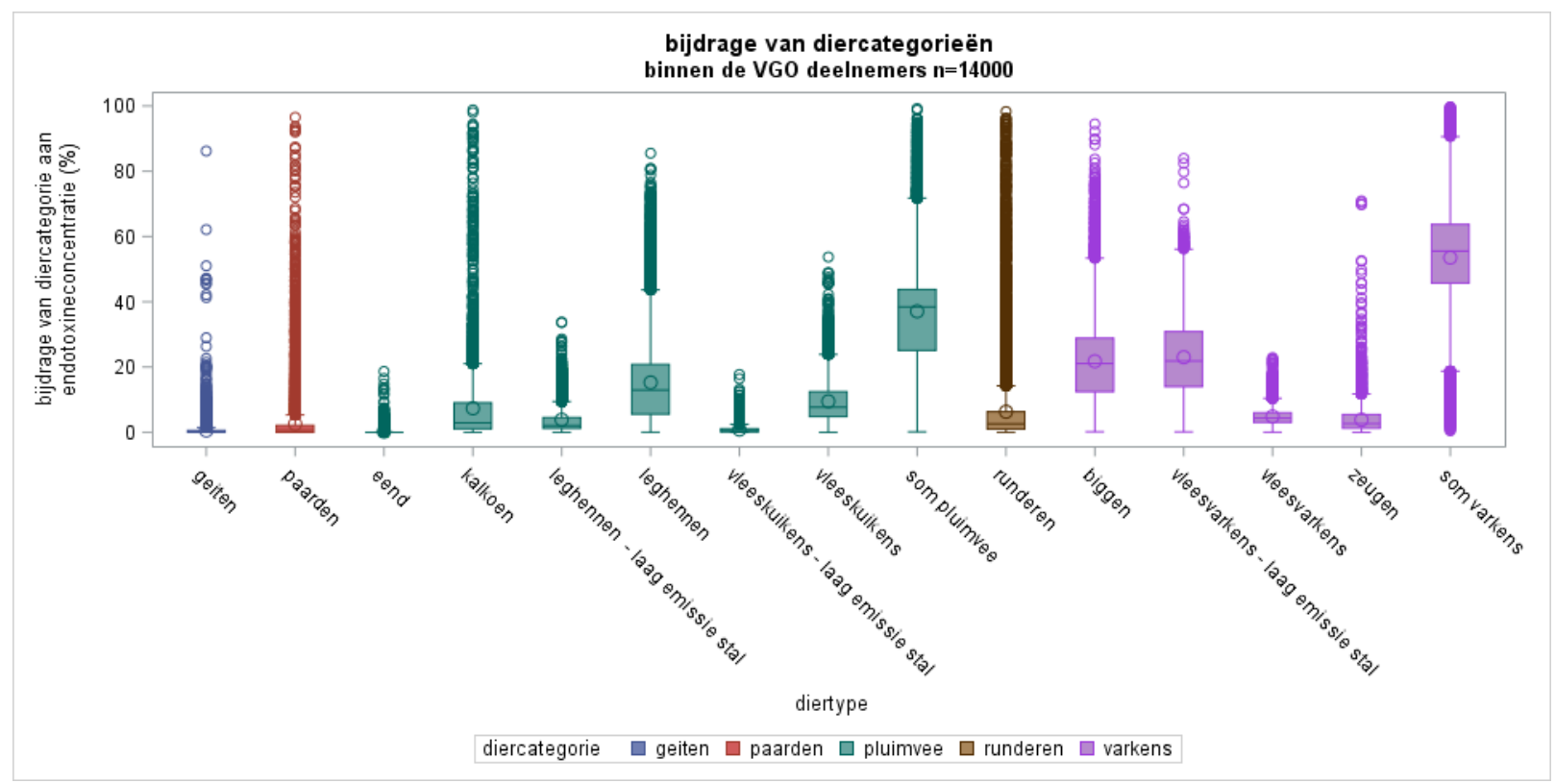

Figuur 17. Verdeling van ruimtelijke bijdrage van diercategorieën en subtypes daarbinnen aan de endotoxineconcentratie op de circa 14000 receptorpunten (box-plot met gemiddelde en mediaan).

Hoewel rundvee over alle receptorpunten genomen de kleinste bijdrage heeft $(<5 \%)$ zijn er veel receptorpunten waar de bijdrage meer dan $10 \%$ is, soms oplopend tot $100 \%$. De figuur laat zien dat ook kleinere sectoren, met minder bedrijven (kalkoenen), op specifieke receptorpunten een hoge bijdrage aan de endotoxineconcentratie kunnen leveren. Ook paarden leveren op een aanzienlijk aantal receptorpunten een relatief hoge bijdrage aan de omgevingsendotoxine-niveaus. Dit is ook terug te zien in figuur 18 waarin het aandeel van de totale bijdrage van de diercategorieën in het gehele onderzoeksgebied is uitgezet in een taart-diagram. 


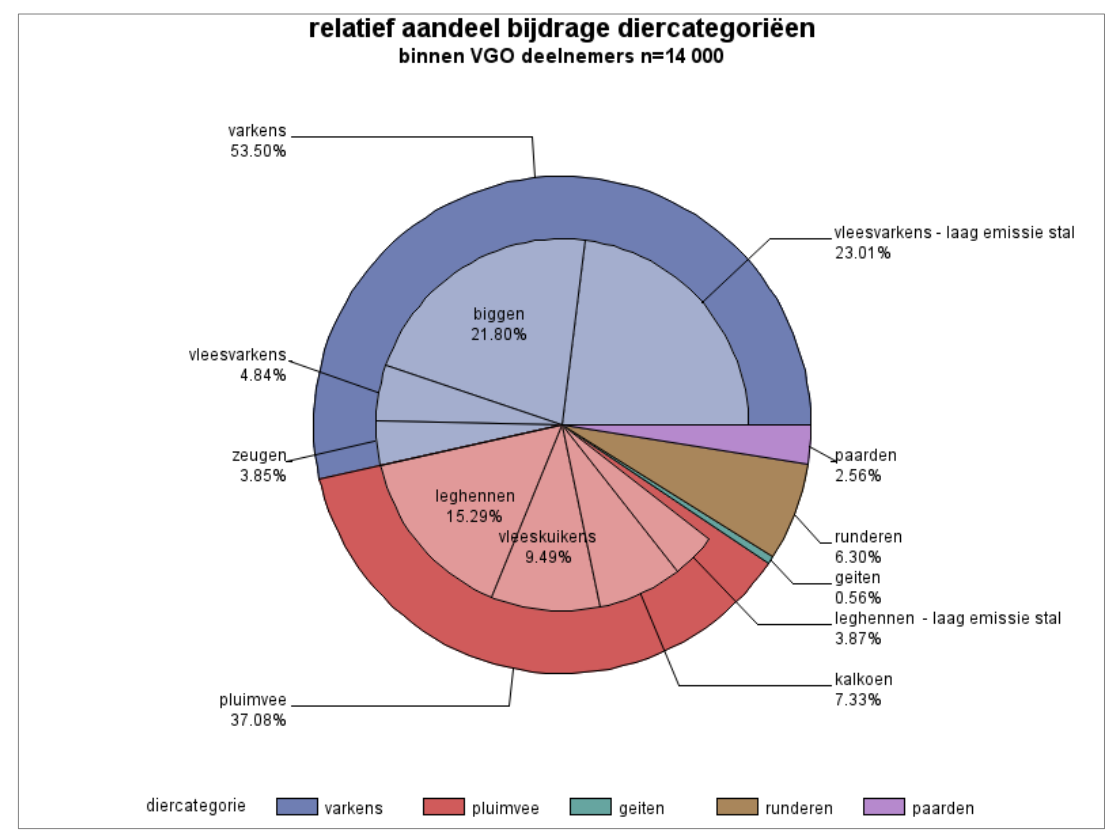

Figuur 18. Overzicht van de totale bijdrage aan de endotoxine concentratie van diercategorieën en subtypes daarbinnen voor de circa 14000 receptorpunten.

Ten slotte is onderzocht of de relatieve bijdrage verandert als gebruik wordt gemaakt van de gridcoördinaten in plaats van de woonadressen van de VGO deelnemers. Dit blijkt niet het geval en is uitgebreid beschreven in de Appendix 2B.

Op 1156 receptorpunten, circa 8\% van de 14000 receptorlocaties, wordt de endotoxineconcentratie voor meer dan $80 \%$ door één diersoort bepaald. Wanneer voor deze punten gekeken wordt naar de verdeling over diercategorieën (figuur 19) blijkt dat net als voor het gehele gebied geldt dat varkens en pluimvee de meest dominante diercategorieën zijn. Hierbij is de rol van varkens iets meer prominent aanwezig dan voor het gehele gebied.

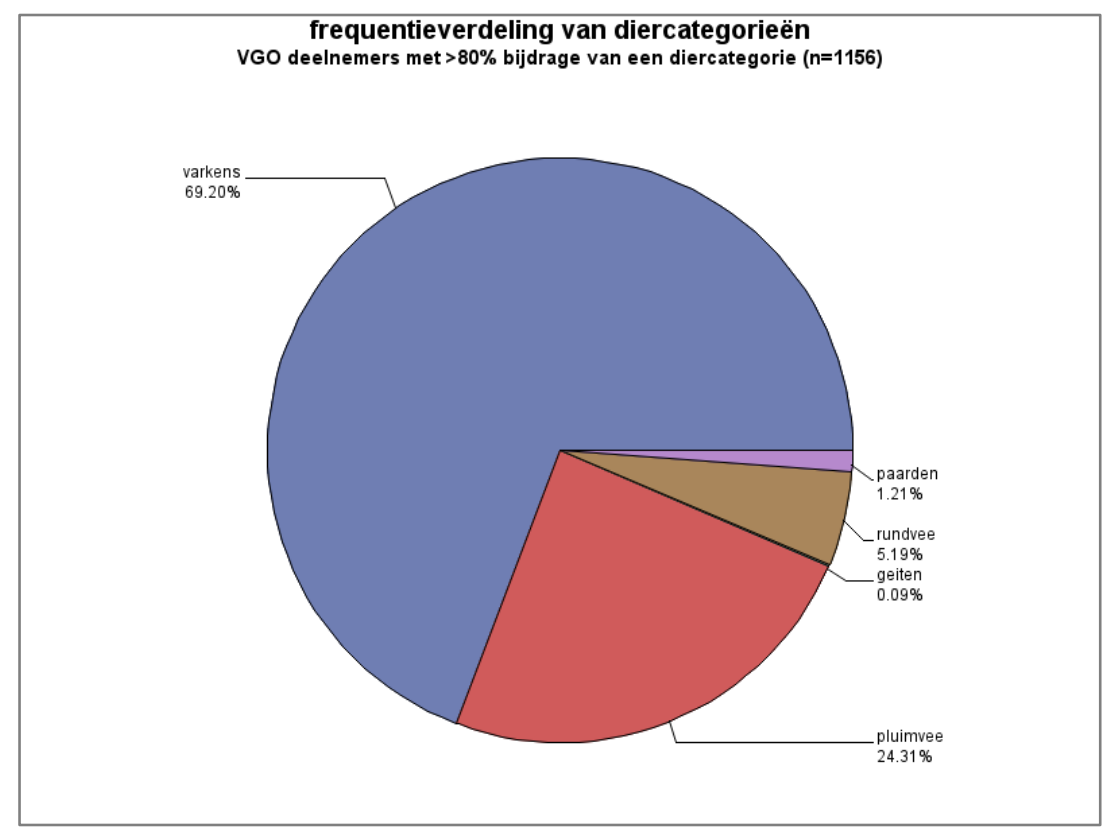

Figuur 19. Frequentieverdeling van voorkomen van diercategorieën voor de $\mathbf{1 1 5 6}$ locaties waar de endotoxineconcentratie grotendeels $(>80 \%$ ) door één diercategorie bepaald wordt. 
Uit figuren 16-19 blijkt dat voor verschillende deelgebieden in het $70 \times 70 \mathrm{~km}^{2}$ gebied grote verschillen in relatieve bijdrage van een diersoort aan de endotoxineconcentratie kunnen bestaan. Deze resultaten geven al aan dat reductie van endotoxineniveaus in de omgeving alleen effectief kan plaatsvinden als gericht op een specifieke locatie wordt gekeken welke veehouderijen relevant bijdragen aan de omgevingsconcentratie. Voor pluimvee bijvoorbeeld, met een bijdrage van gemiddeld $40 \%$ aan de endotoxineconcentratie over alle receptorpunten genomen, zal een $50 \%$ reductie tot een gemiddelde bijdrage over alle receptorpunten genomen van maximaal $20 \%$ leiden. Op specifieke locaties zal dit groter, op andere lager zijn, afhankelijk van de lokale omstandigheden (aantallen pluimveebedrijven, omvang van de bedrijven, etc.) en samenhangen met het lokale effect van bestaand en voorgenomen beleid. Generieke omvangrijke emissiereducties in een sector kunnen dus over het geheel genomen tot beperkter reducties in endotoxineconcentratie leiden, vooral in die gevallen waarin sprake is van aanwezigheid van andere relevant bijdragende diersoorten, behalve in gebieden waar een bepaalde diersoort zeer dominant is en op die manier de omgevingsconcentratie endotoxine in hoge mate bepaalt. Hetzelfde geldt voor de kleinere diersoorten. Over het geheel genomen zal reductie in kleine diersectoren met een beperkt aantal bedrijven geen grote verschuivingen in het beeld opleveren, maar lokaal kan dit heel anders uitpakken. Het identficeren van gebieden waar een bepaalde dieroort domineert vergt nadere uitwerking welke niet in het huidige onderzoek is voorzien. Gedacht kan worden aan het maken van contourplots waarin de maximale dierbijdrage ruimtelijk uitgezet wordt, waardoor identifcatie van deelgebieden die gedomineerd worden door een bepaalde diersoort mogelijk is. Voorbeelden hiervan voor de deelgebieden rond Asten en Someren en Venray (figuur 20) laten zien dat de mate waarin de meest dominante diersoort bijdraagt veelal ruimtelijk beperkt van omvang is, wat nogmaals illustreert dat de endotoxine concentratie door verschillende diersoorten verklaard wordt.
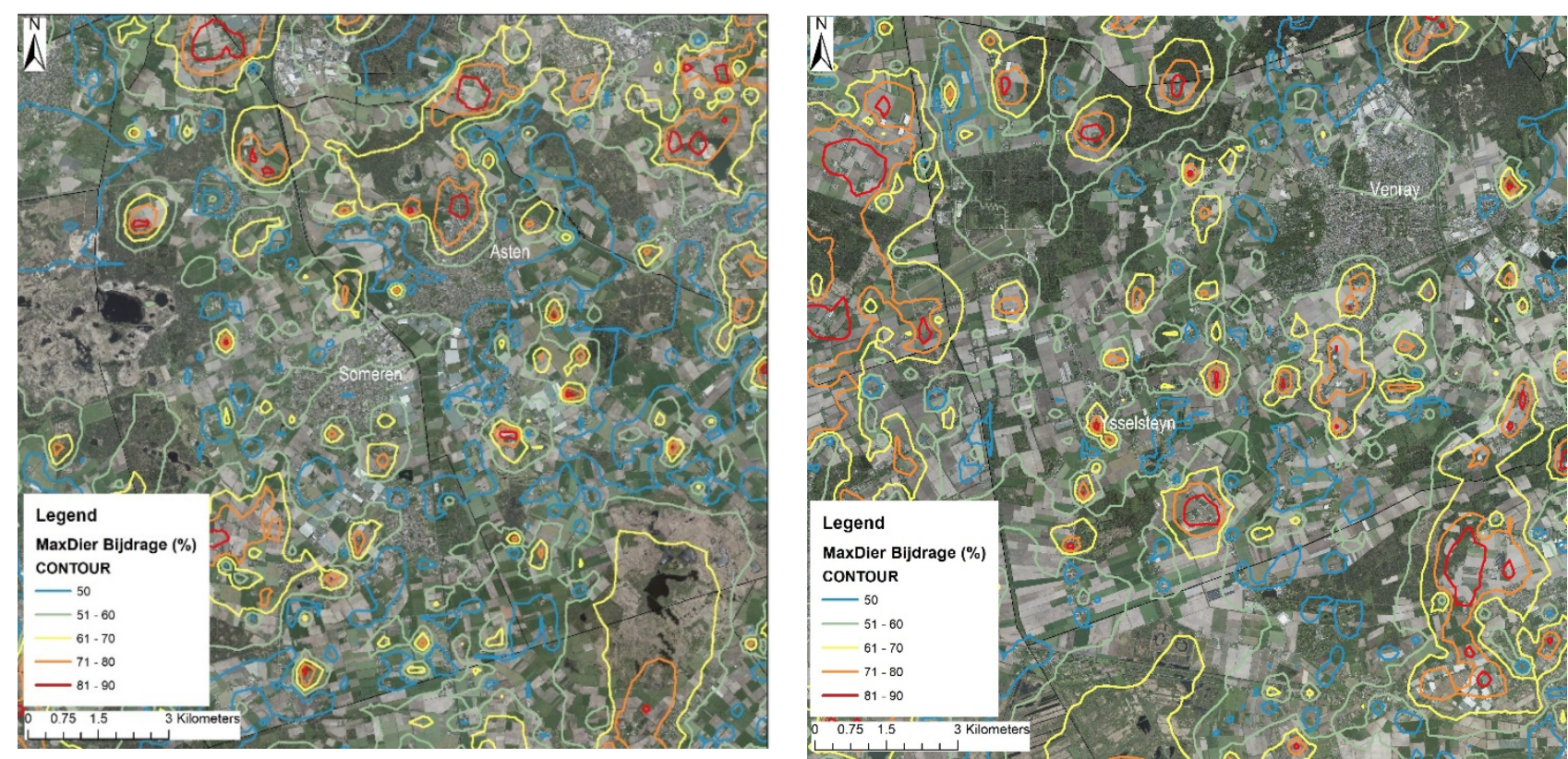

Figuur 20a en 20b. Contourlijnen voor de maximale bijdrage van één diercategorie op de endotoxine concentratie voor de deelgebieden rond Asten en Someren (links) en Venray (rechts) binnen het VGO onderzoeksgebied. Lijnen representeren maximale bijdrage van $<50 \%, 51-60 \%, 61-70 \%, 71-$ $80 \%$ en $81-90 \%$ van de meest bijdragende diercategorie. 


\section{Conclusies}

Modelberekeningen laten zien dat keuzes voor de precisie van de berekeningen (rekenen met; een groot aantal bronnen rond een receptorpunt, preciezer informatie over de locatie van de bronnen, een klein oppervlak voor de ruwheidsparameter) de uitkomsten van de modellen beïnvloeden. Ook de keuze voor de rekenperiode beïnvloedt de uitkomsten door variatie in de meteorologie-parameters. De omvang van de invloed van deze factoren is transparant gemaakt en samen kunnen deze factoren de uitkomsten maximaal enkele tientallen procenten beïnvloeden. Deze variatie in uitkomsten wordt als relatief beperkt gezien in vergelijking met de onzekerheden rond de schattingen voor de emissie van stof en het endotoxinegehalte van stofdeeltjes.

Vergelijkingen tussen met het verspreidingsmodel berekende jaargemiddelde endotoxineconcentraties en gemeten endotoxineconcentraties laten zien dat gemodelleerde en gemeten concentraties over het geheel genomen goed overeenkomen als de warmte-emissie wordt meegenomen in de modelberekeningen. Het verspreidingsmodel verklaart een aanzienlijke mate van variatie gemeten tussen locaties.

Ook is de overeenkomst tussen de endotoxineconcentraties verkregen met het verspreidingsmodel en het LUR-model over het algemeen goed. De mate van variatie verklaard door het verspreidingsmodel is vergelijkbaar met de mate van variatie verklaard door het LUR-model.

De validatiestudie geeft ook aanwijzingen dat op specifieke locaties de verschillen tussen gemodelleerde en gemeten concentraties aanzienlijk kunnen zijn. Hieraan kunnen meerdere factoren ten grondslag liggen:

- Emissiefactoren voor endotoxine zijn afgeleid van stofemissiefactoren en gebaseerd op beperkte aantallen metingen en in sommige gevallen op extrapolaties of informatie afkomstig uit de literatuur. De emissiefactoren zijn daardoor onvermijdelijk beperkt in nauwkeurigheid.

- Emissiefactoren beschrijven de gemiddelde emissie per dier. Bekend is dat de emissie voor individuele bedrijven aanzienlijk kan afwijken van deze gemiddelde emissie, vermoedelijk als gevolg van verschillen in structurele kenmerken van de bedrijven en bedrijfsvoering en management. Er is geen geschikte manier om deze variatie in emissie mee te nemen in de modellen behalve door een omvangrijke meetinspanning op bedrijfsniveau.

- De emissiegegevens zijn toegepast op de vergunde dieraantallen. Op bedrijven kunnen de dieraantallen afwijken van de vergunde aantallen.

- In de verspreidingsmodellen wordt rekening gehouden met stalkenmerken en de aanwezigheid van emissiereductiemaatregelen. Recente resultaten van onderzoek naar de effectiviteit van gaswasinstallaties in de varkenshouderij en ervaringen met het gebruik van deze maatregelen in de praktijk laten zien dat de gebruikte voorveronderstellingen in de verspreidingsmodellen niet altijd juist hoeven te zijn.

- Daarnaast zijn er nog andere onzekerheden in de modellering zoals de rol van bebouwing en begroeiing waar geen rekening mee wordt gehouden.

De uit deze factoren voortvloeiende onnauwkeurigheden, onzekerheden en inschattingsfouten kunnen ertoe leiden dat modelvoorspellingen op specifieke locaties niet juist zijn. De in dit onderzoek uitgevoerde verkenningen naar gebruik van hybride modellen, waarbij verspreidingsmodellen en LURmodellen gecombineerd worden, ondersteunen de suggestie dat op lokaal niveau de endotoxineconcentraties verkregen met verspreidingsmodellen kunnen afwijken van de werkelijkheid, hoewel gemiddeld genomen de modellen overeenkomen met de meetresultaten uit het VGOonderzoek. 
De modelberekeningen voor het VGO-gebied laten een aanzienlijke variatie in endotoxineconcentratie zien. Het aantal punten met een $99,5 \%$ percentielwaarde hoger dan $30 \mathrm{EU} / \mathrm{m}^{3}$ (dus $30 \mathrm{EU} / \mathrm{m}^{3}$ wordt in $0,5 \%$ van de tijd overschreden) is $1,8 \%$. Deeltjes van alle groottes dragen bij aan de endotoxineconcentratie op een receptorpunt maar de variatie in de bijdrage is groot en hangt af van diersoort en afstand. Er zijn meerdere 'hotspots' met zeer lokaal verhoogde concentraties endotoxine waar te nemen, op locaties met een hoge dichtheid aan veehouderijbedrijven. Alle diersoorten dragen bij aan de concentratie endotoxine op de verschillende receptorpunten, maar de bijdrage varieert sterk. Varkens hebben de grootste bijdrage in VGO-gebied, gevolgd door pluimvee. Vooral enkele diersoorten die maar een beperkt aantal bedrijven hebben in de onderzochte regio hebben een markant bijdrage-patroon, met alleen zeer lokaal, op een paar locaties, een duidelijke bijdrage aan de endotoxineconcentratie. Het feit dat de endotoxineconcentratie op een bepaalde locatie veel determinanten kent, betekent dat reductie van omgevingsconcentraties maar tot op zekere hoogte realiseerbaar is door emissie-reducerende maatregelen die zich tot één diersoort beperken.

De gegenereerde endotoxine concentratie informatie over een groot gebied in Nederland met veel intensieve veehouderij is in deze rapportage maar beperkt ontsloten. De beschikbare gegevens lenen zich voor een gebiedsgerichte benadering waarbij op basis van gemodelleerde gegevens hot-spot gebieden kunnen worden geïdentificeerd waar zich regelmatig hoge endotoxine niveaus voordoen. Voor deze gebieden kan onderzocht worden of aanvullende maatregelen voor fijnstof emissies of endotoxine emissies wenselijk zijn om de omgevingsniveaus te beperken. Dat kan handvatten opleveren om effecten van emissies op omgevingsconcentraties endotoxine te verminderen, met name in de gebieden met een grote dichtheid aan bedrijven. 


\section{LITERATUURONDERZOEK NAAR EFFECTEN VAN ENDOTOXINEN BIJ LAGE CONCENTRATIES}

\section{Inleiding}

Eén van de doelstellingen van dit onderzoeksproject is het onderzoeken welke relaties er zijn tussen endotoxineblootstelling en gezondheidseffecten bij omwonenden. Effecten op de luchtwegen als gevolg van hoge, met name beroepsmatige, blootstelling zijn uitgebreid beschreven in de wetenschappelijke literatuur. In 2010 heeft de Gezondheidsraad een grenswaarde van $90 \mathrm{EU} / \mathrm{m}^{3}$ voorgesteld voor de werkomgeving. Deze grenswaarde was gebaseerd op een acuut effect op de longfunctie na zes uur blootstelling aan endotoxine-bevattend katoenstof via de lucht. De geschatte extra daling van de longfunctie als gevolg van chronische blootstelling aan $90 \mathrm{EU} / \mathrm{m}^{3}$ werd beperkt geacht en niet gezien als nadelig voor de gezondheid. ${ }^{22} 23$ Door toepassing van een onzekerheidsfactor 3 kwam de Gezondheidsraad in 2012 tot een voorgestelde grenswaarde voor de buitenlucht van 30 $\mathrm{EU} / \mathrm{m}^{3}$. Er zijn weinig directe observaties van mogelijke gezondheidseffecten door blootstelling aan endotoxine bij deze relatief lage endotoxineniveaus in de buitenlucht rond veehouderijen. Dit systematisch literatuuronderzoek geeft een overzicht van effecten op de luchtwegen bij lage inhalatoire blootstelling aan endotoxinen (tot $100 \mathrm{EU} / \mathrm{m}^{3}$ ), en een beoordeling van de kwaliteit van de onderliggende studies. Het literatuuronderzoek is recent als Engelstalige rapportage verschenen in het peer-reviewed, open access tijdschrift 'Environmental Health'. Het artikel is opgenomen als bijlage (Appendix 3 en 4).

\section{Methoden}

\section{Studieopzet en inclusiecriteria}

Dit literatuuronderzoek is uitgevoerd volgens de PRISMA richtlijn. De PubMed database is gebruikt om literatuur te zoeken (tot 14 februari 2017). De zoektermen waren gebaseerd op een combinatie van endotoxine, blootstelling, en relevante luchtwegeffecten. De volledige zoektermen zijn beschreven door Farokhi et al. en beschikbaar in Appendix 3 en A4.1. Daarnaast zijn referenties van geïncludeerde studies en relevante literatuurstudies doorzocht voor additionele artikelen. De volgende inclusiecriteria werden aangehouden:

1. experimenteel of observationeel onderzoek, in een humane onderzoekspopulatie;

2. endotoxinemetingen op basis van actieve of passieve luchtmonstername, of endotoxinemodellering op basis van luchtmetingen;

3. het gemiddelde endotoxineniveau was lager dan $100 \mathrm{EU} / \mathrm{m}^{3}$;

4. goed gedefinieerde luchtwegeffecten, bijvoorbeeld longfunctiemetingen of luchtwegsymptomen;

5. een volledige, 'peer-reviewed' rapportage van onderzoek in het Engels, Nederlands, Duits, of Frans.

\section{Gegevensanalyse en beoordeling kwaliteit}

Karakteristieken en resultaten zijn geëxtraheerd uit iedere geïncludeerde studie, en vervolgens samengevat in overzichtstabellen en 'forest plots'. De kwaliteit van de geïncludeerde studies werd beoordeeld door twee onderzoekers (zie Appendix voor details) met behulp van een methode ontwikkeld voor observationeel onderzoek (de National Institutes of Health (NIH) 'Quality Assessment Tool for Observational Cohort and Cross-Sectional Studies'). Met deze methode hebben de 
onderzoekers 14 methodologische karakteristieken van het onderzoek beoordeeld. Studies met een score van $\geq 90 \%$ werden als 'sterk' beschouwd, studies met een score van 70-90\% 'matig', en studies met een score lager dan 70\% ' $z$ wak'. De resultaten konden niet verder geaggregeerd worden in een meta-analyse, gezien de diversiteit van de studies op het gebied van onderzoek setting en onderzoekpopulatie, de onderzochte luchtwegeffecten, en de manier waarop endotoxineniveaus zijn geanalyseerd in relatie tot effecten.

\section{Best-evidence synthese}

In plaats van een meta-analyse werd een 'best-evidence' synthese uitgevoerd om tot een samenvattende conclusie te kunnen komen. In deze synthese werden uitsluitend studies meegenomen die een blootstelling-respons relatie hebben geanalyseerd voor endotoxine en een effect op de luchtwegen. Voor longfunctie ( $\mathrm{FEV}_{1}$, ofwel de één-secondewaarde) en drie verschillende luchtwegsymptomen (piepen op de borst, hoesten, (nachtelijke) astmasymptomen) waren voldoende studies beschikbaar voor een best-evidence synthese. De definities beschreven in Tabel 1 werden aangehouden, waarbij de methode zoals beschreven door Proper et al. werd uitgebreid met 'zwak bewijs'. ${ }^{24}$

Tabel 1. Definities om studies te beoordelen in de best-evidence synthese.

\begin{tabular}{|c|c|}
\hline Mate van bewijs & Definitie \\
\hline Consistente resultaten & $\begin{array}{l}75 \% \text { van de studies laat statistisch significante }(p<0,05) \text { resultaten zien } \\
\text { met dezelfde richting van associatie }\end{array}$ \\
\hline Sterk bewijs & Consistente resultaten, twee of meer studies van hoge kwaliteit \\
\hline Matig bewijs & $\begin{array}{l}\text { Consistente resultaten, één studie van hoge kwaliteit, en ten minste één } \\
\text { studie van lage kwaliteit, of consistente resultaten in meerdere studies } \\
\text { van lage kwaliteit }\end{array}$ \\
\hline Zwak bewijs & $\begin{array}{l}\text { Geen consistente resultaten, alle studies laten resultaten in één richting } \\
\text { zien, waarvan ten minste twee statistisch significant }(p<0,05) \text {, en geen } \\
\text { conflicterende resultaten }\end{array}$ \\
\hline Onvoldoende bewijs & $\begin{array}{l}\text { Slechts één studie beschikbaar, of conflicterende resultaten in } \\
\text { verschillende studies }\end{array}$ \\
\hline
\end{tabular}

\section{Resultaten}

\section{Selectie van artikelen}

In totaal werden 1362 artikelen gevonden met de PubMed zoektermen. Figuur 21 laat de selectie van artikelen zien volgens het PRISMA stroomschema. Na screening op basis van abstract en titel bleven 166 artikelen over waarvan de volledige tekst is beoordeeld aan de hand van de inclusiecriteria. De meeste van deze artikelen vielen af vanwege te hoge endotoxineniveaus, de manier waarop endotoxine was gemeten, of de studieopzet. In totaal zijn 31 artikelen geïncludeerd in dit literatuuronderzoek. 


\section{Karakteristieken van geïncludeerde studies}

De meeste studies waren dwarsdoorsnedestudies, zeven hadden een longitudinale opzet (follow-up periode tussen vijf dagen en 11 jaar), en twee waren experimentele studies. Zestien studies waren uitgevoerd in Europese landen (met name West-Europa en Scandinavië), elf studies waren afkomstig uit de Verenigde Staten, en de overige uit Australië, Nieuw-Zeeland, Canada, en Pakistan. Studies waren tussen 1987 en 2016 gepubliceerd. De meeste studies onderzochten beroepsmatige endotoxineblootstelling $(n=23)$ in zeer diverse sectoren waaronder afval(water)verwerking, hout- en textielindustrie. Vier studies onderzochten gevoelige populaties (kinderen met astma, volwassenen met COPD). De overige studies richtten zich op kinderen, of op gezonde volwassenen in een experimentele opzet. Het aantal deelnemers liep uiteen van 22 tot 3867 . Een volledig en gedetailleerd overzicht van de karakteristieken van de geïncludeerde studies en bijbehorende referenties naar de studies is beschikbaar in Appendix 3 en 4 . In een aantal gevallen waren studies geïnitieerd vanwege specifieke redenen, zoals een plotselinge toename van gezondheidsklachten bij werknemers. In een aantal van deze studies is ook andere luchtverontreiniging gemeten dan endotoxine. Een overzicht hiervan staat in Appendix 3 en 4 (A4.2). De meeste studies hebben inhaleerbaar stof verzameld met behulp van persoonlijke monstername tijdens werkuren. Een aantal studies heeft stationaire monstername uitgevoerd, of voorspellingen van inhaleerbare endotoxine op basis van een dispersiemode ${ }^{25}$ of een regressiemode ${ }^{26}$. Endotoxine werd in alle studies gemeten met de LAL-assay. Gemiddelde blootstellingsniveaus waren in de meeste studies (veel) lager dan $100 \mathrm{EU} / \mathrm{m}^{3}$. Een volledig overzicht van de niveaus per studie staat in Appendix 4. Longfunctiemetingen zijn gerapporteerd door 21 studies, met name met $\mathrm{FEV}_{1}$ en de geforceerde vitale capaciteit (FVC) als uitkomstmaten. Vrijwel alle studies hebben luchtwegsymptomen geregistreerd op basis van een vragenlijst of telefonisch interview.

\section{Beoordeling kwaliteit}

Een overzicht van de score per studie op elk van de 14 methodologische karakteristieken staat in de Appendix (A5.3). Het percentage van de totaal haalbare score varieerde tussen $55 \%$ en $100 \%$. De studies werden beschouwd als sterk ( $n=9)$, matig $(n=13)$, en zwak $(n=9)$.

\section{Resultaten}

De hoofdresultaten van vragenlijstonderzoek, spirometrie, en blootstelling-responsanalyses zijn per studie samengevat in Appendix 4 (A4.4-A4.6). Tien studies lieten een statistisch significant verhoogde prevalentie zien van diverse luchtwegsymptomen (hoesten, piepen op de borst, kortademigheid, (werk-gerelateerde) benauwdheid en astmaklachten, en chronische bronchitis) bij blootgestelde mensen vergeleken met een niet- of lager blootgestelde controlegroep. Kortdurende blootstelling aan $7,40 \mathrm{EU} / \mathrm{m}^{3}$ (gedurende één uur) in een experimentele opzet had geen meetbare invloed op de prevalentie van hoestklachten. De forest plots (Figuur 22a-d) laten een overzicht zien van de effecten van blootstelling aan endotoxine (en andere bioaerosolen) op luchtwegsymptomen zoals gepresenteerd in de geïncludeerde studies. De odds ratio (of exp(beta) voor symptoomscores) voor astma, benauwdheid, hoesten, en piepen op de borst lijken in het algemeen verhoogd bij mensen die blootgesteld zijn aan bio-aerosolen, hoewel de betrouwbaarheidsintervallen breed zijn en het effect vaak niet significant. 
Drie studies vonden een statistisch significant verschil in longfunctiewaarden ( $F E V_{1}$ en/of FVC) bij aanvang van de werkdag bij blootgestelde mensen vergeleken met een niet- of lager blootgestelde controlegroep. Zes studies lieten een statistisch significante longfunctiedaling ( $\mathrm{FEV}_{1}$ en/of FVC) zien over de werkdag bij blootgestelde werknemers. Verschillende andere studies vonden geen effect op
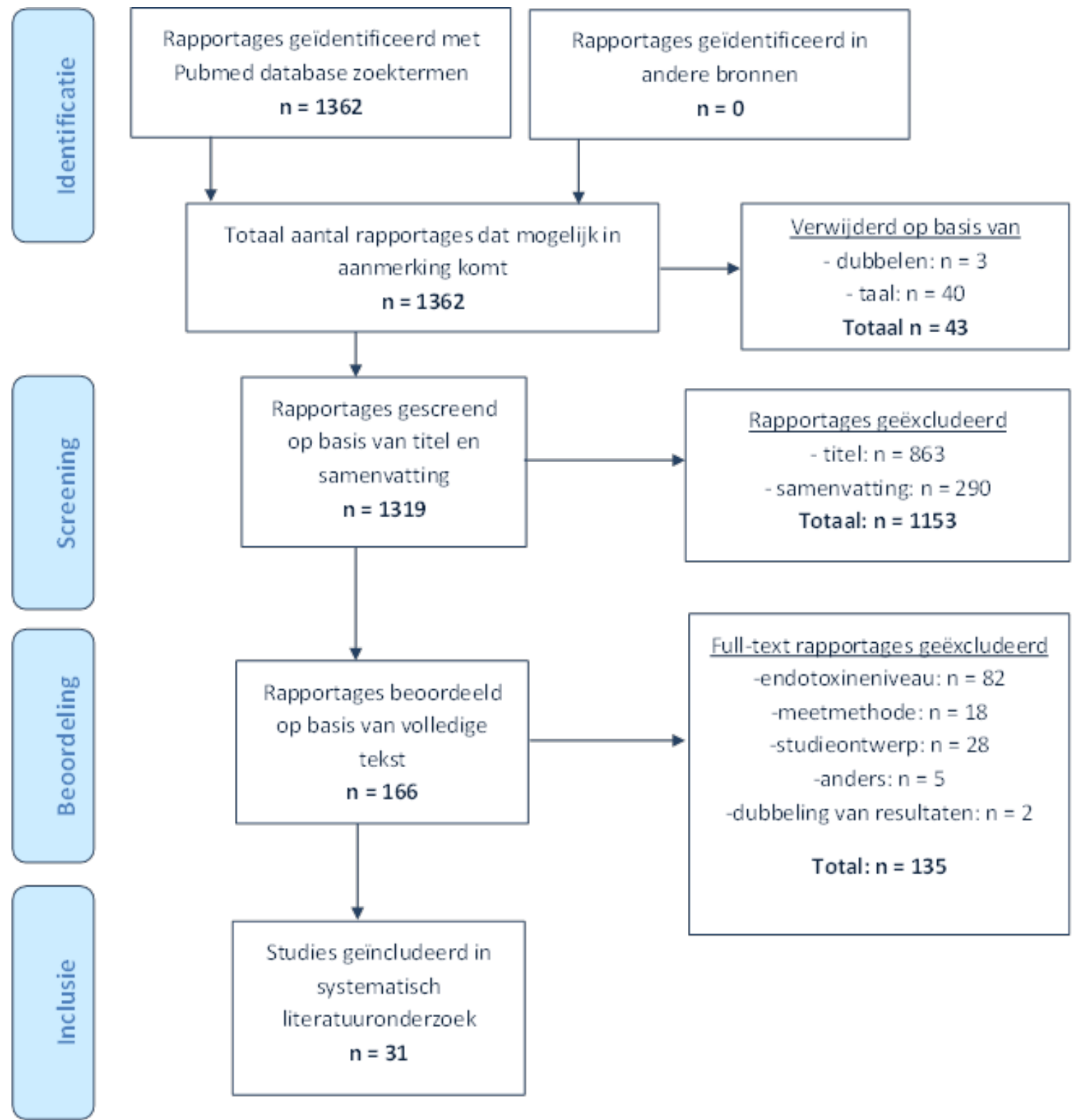

Full-text rapportages geëxcludeerd

-endotoxineniveau: $\mathrm{n}=82$

-meetmethode: $\mathrm{n}=18$

-studieontwerp: $\mathrm{n}=28$

-anders: $n=5$

-dubbeling van resultaten: $n=2$

Total: $\mathbf{n}=135$

Figuur 21. Selectie van artikelen volgens het PRISMA-stroomschema.

de longfunctie. Experimentele blootstelling aan 7,40 EU/m $/ \mathrm{m}^{3}$ gedurende één uur had geen meetbare invloed op de longfunctie. Vier studies vonden geen verlaagde longfunctie bij hoger blootgestelde werknemers. Een studie bij werknemers van een papierfabriek vond geen verschil in jaarlijkse afname van de longfunctie tussen lager en hoger blootgestelde mensen (endotoxineniveaus tussen 6 en 370 $\mathrm{EU} / \mathrm{m}^{3}$ ). Een andere longitudinale studie vond ook geen extra daling (ten opzichte van referentiewaarden) van de longfunctie na 5 jaar blootstelling aan endotoxineniveaus van $28 \mathrm{EU} / \mathrm{m}^{3}$. 
Achttien studies hebben een blootstelling-responsrelatie tussen endotoxineblootstelling en luchtwegeffecten geanalyseerd. Een statistisch significante blootstelling-afhankelijke toename in symptomen werd gerapporteerd voor hoesten, (nachtelijke) astma-gerelateerde klachten, piepen op de borst, en slijm ophoesten. Vijf studies vonden een significante blootstelling-afhankelijke associatie met een lagere longfunctie $\left(\mathrm{FEV}_{1}\right)$.
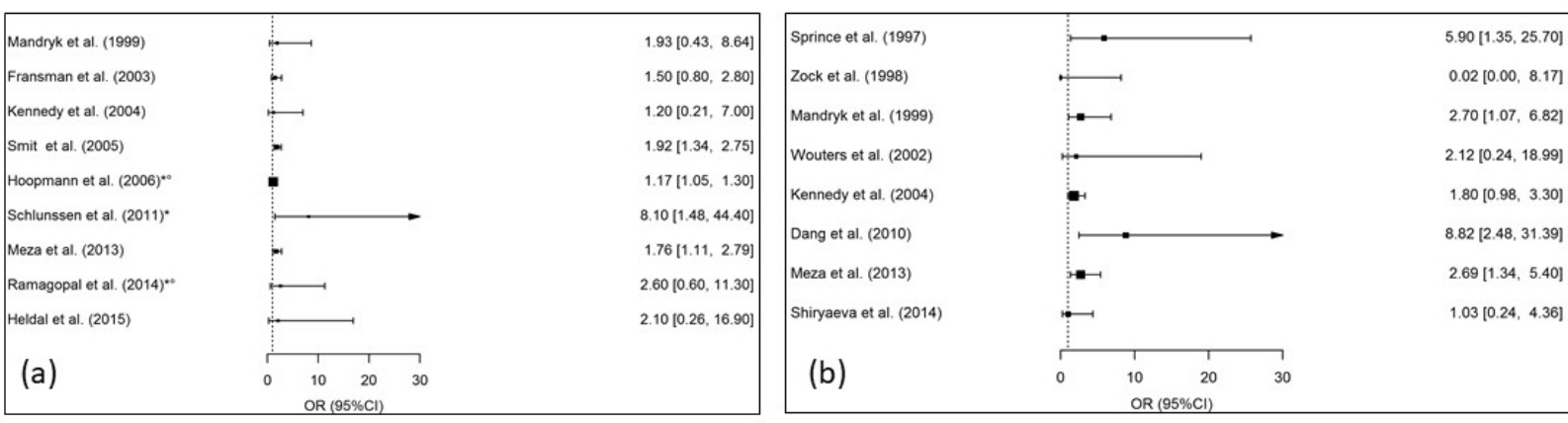

\begin{tabular}{|c|c|c|}
\hline Sprince et al. (1997) & $=1$ & $3.10[1.39,6.90]$ \\
\hline Zock et al. (1998) & $\longleftrightarrow$ & $0.04[0.00,22.57]$ \\
\hline Mandryk et al. (1999) & $\leftrightarrow$ & $5.09[2.19,11.82]$ \\
\hline Wouters et al. (2002) & 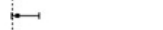 & $2.80[0.72,10.96]]$ \\
\hline Kennedy et al. (2004) & 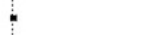 & $1.20[0.60,2.40]$ \\
\hline Smit et al. (2005) & - & $1.45[1.14,1.85]$ \\
\hline Dang et al.(2010) & $\longmapsto$ & $30.10[10.65,85.06]$ \\
\hline Shiryaeva et al. (2014) & : & $1.07[0.56,2.04]$ \\
\hline Heldal et al. (2015) & 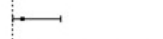 & $4.70[1.16,19.00]$ \\
\hline (c) & 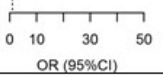 & \\
\hline
\end{tabular}

\begin{tabular}{|c|c|c|}
\hline Mandryk et al. (1999) & 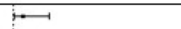 & $3.68[1.24,10.90]$ \\
\hline Wouters et al. (2002) & $\Leftrightarrow$ & $1.70[0.34,8.56]$ \\
\hline Fransman et al. (2003) & . & $1.20[0.72,2.00]]$ \\
\hline Kennedy et al. (2004) & 4 & $1.30[0.58,2.90]$ \\
\hline Smit et al. (2005) & ! & $0.71[0.55,0.91]$ \\
\hline Hoopmann et al. (2006)"• & 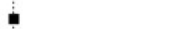 & $1.15[1.04,1.27]$ \\
\hline Horick et al. (2006) $)^{*}$ & $\longrightarrow$ & $5.56[1.19,26.03]$ \\
\hline Dang et al. (2010) & $\longrightarrow$ & $14.40[3.22,64.39]$ \\
\hline Meza et al. (2013) & 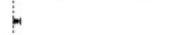 & $1.81[1.11,2.96]$ \\
\hline Ramagopal et al. (2014)** & 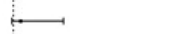 & $3.00[0.61,14.80]$ \\
\hline Shiryaeva et al. (2014) & $\leftrightarrow$ & $1.06[0.15,7.63]$ \\
\hline (d) & $\begin{array}{llllll} & 1 & 1 & & \\
0 & 10 & 20 & 30 & 40\end{array}$ & \\
\hline
\end{tabular}

Figuur 22a-22d. 'Forest plots' met odds ratio's (OR) voor astma (a), benauwdheid (b), hoesten (c) en piepen op de borst (d) in relatie tot blootstelling aan bio-aerosolen. Odds ratio's op basis van (hoger) blootgesteld versus niet of lager blootgesteld.

*OR voor blootstelling-respons relatie met endotoxine

${ }^{\circ}$ Studie naar niet-beroepsmatige blootstelling

\section{Analyses in gevoelige subgroepen}

Een overzicht van analyses in gevoelige subgroepen wordt gegeven in een Appendix (A4.6). Een aantal studies laat een sterker effect zien bij deelnemers met astma of met een allergische aanleg. Piepen op de borst, nachtelijk hoesten, en andere astmaklachten kwamen alleen vaker voor bij kinderen van ouders met allergische aanleg in een grote Duitse studie waarin endotoxineniveaus in de buitenlucht waren gemodelleerd met verspreidingsmodellen.

\section{'Best-evidence' synthese}

De best-evidence synthese staat samengevat in Tabel 2. Een meer gedetailleerd overzicht, inclusief de referenties naar de onderliggende studies staat beschreven in Appendix 4 (A4.7). Voor hoesten werd onvoldoende bewijs gevonden voor een associatie met endotoxine. Voor piepen op de borst, longfunctie ( $\mathrm{FEV}_{1}$ ), en (nachtelijke) astmasymptomen werd zwak bewijs gevonden voor een associatie met lage inhalatoire blootstelling aan endotoxinen. Voor deze luchtwegeffecten lieten alle studies resultaten in één richting zien, waarvan ten minste twee statistisch significant $(p<0,05)$. Vier sterke en één matige studie ondersteunden de hypothese dat $\mathrm{FEV}_{1}$ afneemt bij endotoxineblootstelling. In deze studies was de afname van $\mathrm{FEV}_{1}$ steeds gemeten over de (werk)dag. Twee andere studies lieten een 
niet-significante afname van de $\mathrm{FEV}_{1}$ zien bij hogere blootstelling. Dit werd beschouwd als zwak bewijs omdat minder dan $75 \%$ van de studies significante resultaten lieten zien.

Tabel 2. 'Best-evidence' synthese voor effecten op de luchtwegen bij lage inhalatoire blootstelling aan endotoxinen (tot $100 \mathrm{EU} / \mathrm{m}^{3}$ ), op basis van blootstelling-respons analyses.

\begin{tabular}{|c|c|c|}
\hline Effect op luchtwegen & Bewijs uit geïncludeerde studies & $\begin{array}{l}\text { Mate van } \\
\text { bewijs }\end{array}$ \\
\hline \multirow{2}{*}{ Piepen op de borst } & $\begin{array}{l}\text { Endotoxine is geassocieerd met hogere prevalentie } \\
(p<0,05): 2 \text { sterke en } 1 \text { matige studie } \\
(p>0,05): 1 \text { sterke en } 3 \text { matige studies }\end{array}$ & \multirow{2}{*}{ Zwak bewijs } \\
\hline & $\begin{array}{l}\text { Endotoxine is geassocieerd met lagere prevalentie } \\
(p<0,05):- \\
(p>0,05):-\end{array}$ & \\
\hline \multirow{2}{*}{ Hoesten } & $\begin{array}{l}\text { Endotoxine is geassocieerd met hogere prevalentie } \\
(p<0,05): 1 \text { zwakke studie } \\
(p>0,05): 1 \text { sterke studie }\end{array}$ & \multirow{2}{*}{$\begin{array}{l}\text { Onvoldoende } \\
\text { bewijs }\end{array}$} \\
\hline & $\begin{array}{l}\text { Endotoxine is geassocieerd met lagere prevalentie } \\
(p<0,05):- \\
(p>0,05): 1 \text { sterke studie }\end{array}$ & \\
\hline \multirow{2}{*}{$\begin{array}{l}\text { (Nachtelijke) astma } \\
\text { symptomen }\end{array}$} & $\begin{array}{l}\text { Endotoxine is geassocieerd met hogere prevalentie } \\
(p<0.05): 1 \text { sterke en } 3 \text { matige studies } \\
(p>0.05): 2 \text { matige studies }\end{array}$ & \multirow{2}{*}{ Zwak bewijs } \\
\hline & $\begin{array}{l}\text { Endotoxine is geassocieerd met lagere prevalentie } \\
(p<0,05) \text { : - } \\
(p>0,05) \text { : }\end{array}$ & \\
\hline \multirow{2}{*}{$\mathrm{FEV}_{1}$} & $\begin{array}{l}\text { Endotoxine is geassocieerd met lagere longfunctie } \\
(p<0,05): 4 \text { sterke en } 1 \text { matige studie } \\
(p>0,05): 1 \text { sterke en } 1 \text { matige studie }\end{array}$ & \multirow[t]{2}{*}{ Zwak bewijs } \\
\hline & $\begin{array}{l}\text { Endotoxine is geassocieerd met hogere longfunctie } \\
(p<0,05):- \\
(p>0,05):-\end{array}$ & \\
\hline
\end{tabular}

\section{Discussie en conclusies}

Dit systematisch literatuuronderzoek geeft een overzicht van effecten op de luchtwegen bij niveaus van endotoxineblootstelling die voor kunnen komen in de buitenlucht, bijvoorbeeld in de omgeving van veehouderijen (inhalatoire blootstelling tot $100 \mathrm{EU} / \mathrm{m}^{3}$ ). Verschillende studies beschrijven luchtwegeffecten bij deze lage blootstellingsniveaus, maar de studies zijn zeer verschillend van opzet, uitvoering, alsook de analyse, en bestudeerde uitkomstmaten, en de resultaten zijn onderling vaak inconsistent. Het bewijs uit de verschillende studies die een blootstelling-responsrelatie laten zien is gewogen in een best-evidence synthese. Hieruit kunnen we concluderen dat er zwak bewijs is voor een effect van lage inhalatoire endotoxineblootstelling op de longfunctie $\left(\mathrm{FEV}_{1}\right)$. Ook voor een aantal 
luchtwegsymptomen (piepen op de borst, (nachtelijke) astmaklachten) werd zwak bewijs gevonden. Gezondheidseffecten als gevolg van blootstelling aan lage niveaus in de lucht $\left(<100 \mathrm{EU} / \mathrm{m}^{3}\right)$ lijken gezien de bevindingen in principe plausibel. Nieuwe studies zijn nodig naar effecten van blootstelling aan endotoxine in de buitenlucht en potentiële respiratoire effecten, in het bijzonder in specifieke gevoelige subgroepen in de populatie.

Deze studie had een aantal beperkingen. Zo hadden veel studies een relatief kleine onderzoekspopulatie, waardoor veel resultaten niet statistisch significant waren en puntschattingen resulteerden met brede betrouwbaarheidsintervallen. De oogst van de literatuurstudie bestond uiteindelijk vooral uit dwarsdoorsnede (observationele) studies. Het materiaal was heterogeen voor wat betreft de studieopzet, de statistische methoden, de studiepopulatie, de definitie van blootstelling en luchtwegeffecten en de uitkomsten waren te verschillend voor een meta-analyse of meta-regressie. Als gevolg hiervan kon dus ook geen meta-effect worden geschat. Zonder twijfel zijn de uitkomsten van de literatuurstudie mogelijk vertekend door selectief rapporteren of publicatiebias. En als laatste punt, in de meeste studies is niet alleen sprake van blootstelling aan endotoxine, maar van blootstelling aan een mix van bio-aerosolen. Daardoor is het niet zeker dat endotoxine het causaal agens is. Daarom is uiteindelijk de best-evidence synthese beperkt tot blootstelling-respons relaties met gemeten endotoxine, hoewel dit ook niet uitsluit dat aan endotoxine gecorreleerde agentia een rol spelen. In de werkelijk voorkomende situatie voor omwonenden van veehouderijen speelt uiteraard ook dat de buitenlucht niet alleen stof en endotoxine bevat, maar ook andere agentia in bioaerosolen.

Sterke kanten van dit onderzoek waren de systematische aanpak, het includeren van een expliciete beoordeling van de kwaliteit van studies en het feit dat de analyse beperkt is tot studies waarin de inhalatoire blootstelling aan endotoxine is gemeten.

Op basis van het literatuuronderzoek zijn geen aanwijzingen gevonden voor een lagere prevalentie atopie bij hogere blootstelling aan endotoxine. De meeste studies waarin naar de relatie tussen inhalatoire endotoxine blootstelling en atopie is gekeken betreffen studies bij boeren (inclusief veehouders) die zijn blootgesteld aan gemiddeld hoge endotoxineniveaus die meestal ver boven de $100 \mathrm{EU} / \mathrm{m}^{3}$ liggen. ${ }^{27} 28$ Daarnaast zijn vergelijkbare observaties gedaan in studies waarin is gekeken naar endotoxine in huisstof of matrasstof en atopie bij kinderen en volwassenen. ${ }^{29-31}$ In deze studies in niet gekeken naar blootstellingsniveaus endotoxine in de lucht waardoor ook deze studies zijn uitgesloten van het literatuuronderzoek. De uitkomsten van deze studie moeten in de juiste context worden gezien. Deze studie doet geen uitspraak of endotoxine tot effecten op de luchtwegen kan leiden, maar richt zich specifiek op de vraag of effecten op de luchtwegen nog waarneembaar zijn bij lage niveaus. $\mathrm{Er}$ is een veelheid aan studies, observationeel (dwarsdoorsnede en longitudinaal (over korte (uren of dagen) en langere (jaren) perioden) en experimenteel, waarvan een groot deel betrekking heeft op veehouders, die associaties laten zien tussen hogere niveaus endotoxineblootstelling en effecten op de luchtwegen. Voor de details wordt naar overzichtsartikelen verwezen. ${ }^{19}$ Overigens geldt ook hier dat veehouders ook aan andere microbiële toxinen dan endotoxine alleen worden blootgesteld die tot vergelijkbare effecten kunnen leiden. Echter, met name resultaten van experimenteel toxicologisch onderzoek in diermodellen, maar ook bij de mens, laten 
zien dat in geval van endotoxine sprake is van een causale relatie met effecten op de luchtwegen. Een voorbeeld is een studie waarbij vrijwilligers zuiver endotoxine (lipopolysaccharide (LPS)) inhaleerden en acute longfunctieveranderingen lieten zien. ${ }^{18}$

Het onderzoek geeft aanwijzingen dat gevoelige subgroepen iets sterkere effecten laten zien (astmatici met atopie). Uit ander onderzoek, bij hogere blootstelling, was ook al bekend dat een verschil in gevoeligheid bestaat, voor het optreden van effecten door inhalatie van endotoxine. ${ }^{32}$ Overigens laat een aantal studies ook zien dat een verschil in gevoeligheid te maken kan hebben met genetische factoren die niet met atopie samenhangen. ${ }^{33} 34$ 


\section{VGO STUDIE: HERANALYSE RELATIES MET GEZONDHEIDSEFFECTEN}

\section{Inleiding}

In het VGO-onderzoek zijn associaties beschreven tussen respiratoire symptomen, longfunctie, serologische informatie over sensibilisatie tegen allergenen en afstand tussen de woning en veehouderijbedrijven en dichtheid van veehouderij rond de woning. In het kort zijn de volgende ruimtelijke associaties gevonden die in deze rapportage nader worden onderzocht, maar nu in relatie tot de endotoxineconcentraties in de omgeving:

- Verlaging van de longfunctie bij mensen die veel veehouderijen in hun directe omgeving hebben, vooral bij mensen met 15 of meer bedrijven binnen een kilometer afstand. Dit verband hangt samen met het aantal veehouderijen rond de woning en niet duidelijk met specifieke veehouderijtypen. Geconcludeerd werd dat het meest waarschijnlijk is dat deze lagere longfunctie samenhangt met de (langdurige) blootstelling aan stof en micro-organismen (endotoxine) direct rond de veehouderijbedrijven.

- Een (significant) lagere prevalentie astma en allergische rhinitis (neusallergieën) bij mensen die op korte afstand wonen van veehouderijen, met name varkenshouderijen of rundveebedrijven. Deze bevinding bevestigt eerdere bevindingen voor omwonenden en is in lijn met onderzoek onder veehouders en kinderen van veehouders. Onder deze laatste groepen worden ook minder vaak allergieën gevonden, mogelijk omdat het immuunsysteem zich anders ontwikkelt als gevolg van blootstelling aan micro-organismen en door microorganismen geproduceerde toxinen zoals endotoxinen.

- een verhoogd risico voor COPD-patiënten op complicaties van hun ziekte naarmate ze dichterbij één of meer veehouderijen wonen. Ook gebruiken deze mensen vaker luchtwegmedicatie.

Daarnaast is nog gevonden dat de longfunctie lager was op dagen met hoge ammoniakniveaus in de buitenlucht. Omdat met verspreidingsmodellen niet goed voorspeld kan worden op welk tijdstip de concentratie luchtverontreiniging (en dus ook endotoxine) is verhoogd, zijn geen verdere pogingen ondernomen om deze temporele associaties te onderzoeken met gemodelleerde endotoxineconcentraties.

\section{Methoden}

Globale informatie over de VGO-studie en gebruikte gezondheidseindpunten

Mogelijke verbanden tussen gezondheidseffecten en veehouderijen zijn op verschillende manieren onderzocht. Hiervoor zijn (geanonimiseerde) gegevens van huisartsen over ongeveer 110000 patiënten voor de hele regio bekeken, is een korte vragenlijst ingevuld door ongeveer 15000 mensen en hebben bijna 2500 mensen meegedaan aan een medisch onderzoek (onder meer bloedafname en een longfunctietest). De details over materiaal en methoden zijn in publicaties over het VGOonderzoek te vinden. ${ }^{11-13}$

De analyses in deze rapportage hebben betrekking op het vragenlijstonderzoek en het medisch onderzoek. Het vragenlijstonderzoek bevatte vragen over de gezondheid van de luchtwegen. Er werd gevraagd naar symptomen en aandoeningen zoals kortademigheid, piepen op de borst, astma en COPD. De vragen zijn afkomstig uit een door het 'European Community Respiratory Health Survey-III (ECRHS-III)'-studieconsortium vastgestelde vragenlijst. Daarnaast bevatte de vragenlijst ook vragen over leeftijd, geslacht, rookgewoonten, het aantal jaren dat men in de huidige woning woont en of de persoon woont of werkt op een veehouderij. Na uitsluiting van mensen die wonen of werken op een 
veehouderij, en mensen die minder dan één jaar op hun huidig woonadres wonen, kwamen er 12117 vragenlijstrespondenten in aanmerking voor analyse.

Spirometrie werd uitgevoerd volgens de 'European Respiratory Society (ERS)' richtlijn. Deelnemers werd gevraagd volledig in te ademen en vervolgens alle lucht zo snel en krachtig mogelijk uit te blazen in de spirometer. Vastgesteld zijn de geforceerde vitale capaciteit (FVC), het geforceerde één seconde volume $\left(\mathrm{FEV}_{1}\right.$ ) en de Maximale Mid-expiratoire volumestroom (MMEF). De gemeten longfunctie is vergeleken met externe referentiewaarden van de ERS (Global Lung Initiative-2012 waarden). Door de gemeten waarde te delen door de referentiewaarde wordt het percentage van de voorspelde waarde verkregen dat is gecorrigeerd voor leeftijd, lengte en geslacht van de deelnemers. Het percentage van de voorspelde waarde is in verdere statistische analyses gebruikt. Minimaal 15 minuten na een pufje met een luchtwegverwijderaar (Salbutamol, $2 \times 100 \mu \mathrm{g}$ ) werd opnieuw een longfunctiemeting uitgevoerd (reversibiliteitsbepaling). Met deze informatie kan in epidemiologisch onderzoek tot op zekere hoogte een onderscheid worden gemaakt tussen COPD en astma.

Het serum (deel van bloed zonder cellen en stollingseiwitten) van deelnemers is o.a. gebruikt om te onderzoeken of men aanleg heeft om op allergenen te reageren. Daarvoor is in het laboratorium van het IRAS bepaald of deelnemers in het serum IgE-antilichamen hebben die reageren op veel voorkomende allergenen. Dit wordt de atopische status (of 'atopie') genoemd. In deze studie is op IgE tegen de volgende allergenen getest: graspollen, huisstofmijt, kat en hond (positief wanneer IgE concentratie in serum $>0,35 \mathrm{IU} / \mathrm{ml}$ ). Daarnaast is ook de totale hoeveelheid IgE bepaald. Atopie is in deze studie als volgt gedefinieerd: een positieve test tegen minstens één van de geteste specifieke allergenen en/of een totaal IgE $>100 \mathrm{IU} / \mathrm{ml}$.

\section{Statistische analyse}

De meeste onderzoeksgegevens zijn met multivariabele methoden geanalyseerd. Verbanden zijn indien nodig gecorrigeerd voor verschillen in leeftijd, geslacht en eventuele andere potentieel verstorende variabelen. Associaties tussen endotoxineconcentraties en gezondheidsvariabelen zijn voor dezelfde verstorende variabelen gecorrigeerd als in het VGO-onderzoek. Deze variabelen zijn in de tabellen weergegeven. In geval van onderzoek naar effecten op de luchtwegen zijn specifieke analyses uitgevoerd voor gevoelige subgroepen (individuen met astma, COPD of allergische rhinitis), zoals eerder gedefinieerd in het VGO-onderzoek. De associaties gevonden in het VGO-onderzoek zijn gebaseerd op ruwe 'proxies' van veehouderij gerelateerde omgevingsblootstelling; de belangrijkste in het VGO-onderzoek gebruikte proxies waren afstand tot dichtstbijzijnd bedrijf, en lokale dichtheid van bedrijven. In eerder VGO- onderzoek is aangetoond dat endotoxineconcentraties in de omgeving samenhangen met deze proxies van omgevingsblootstelling. In de presentatie van de resultaten hieronder wordt de nadruk gelegd op het exploreren van de meest relevante (en statistisch significante) VGO- bevindingen en daarbij wordt gekeken of en in welke mate associaties veranderen als analyses worden gebaseerd op gemodelleerde endotoxineconcentraties. Een sterkere associatie mag worden verwacht als analyses worden gebaseerd op (verondersteld) etiologisch relevanter informatie (endotoxineconcentratie) in plaats van ruwe proxies van blootstelling. In Appendix 5 worden de waarden van het 'Akaike Information Criterion (AIC)' gegeven voor de eerdere analyses (op basis van afstand van veehouderijbedrijven en dichtheid rond de woning) en de hier gepresenteerde analyses met gemodelleerde endotoxineconcentraties. Op grond hiervan kan de 'fit' van de verschillende modellen worden vergeleken. Hoe lager het AIC-getal, hoe beter de 'fit'. De modellen waarin endotoxine wordt geassocieerd met gezondheidseffecten laten in ongeveer de helft van de gevallen een betere fit zien dan de modellen op basis van dichtheid of afstand van veehouderijen.

Endotoxine- en stofconcentraties die hoger waren dan het 99,75\% percentiel van de populatie endotoxine-concentratieverdeling, zijn bijgesteld op de concentratie van dat 99,75\% percentiel. Dit is 
gedaan omdat op basis van de validatiestudie en aanvullende analyses een aantal zeer hoge concentraties werden waargenomen die als niet realistisch werden gezien. Deze benadering is gehanteerd om te zorgen dat deze waarnemingen geen onevenredig grote invloed zouden kunnen hebben op de onderzoeksresultaten en eventuele geobserveerde blootstelling-responsrelaties. Sensitiviteitsanalyses waarbij deelnemers met PM10 en endotoxineniveaus hoger dan de 99.5 percentielwaarde werden verwijderd uit de analyse in plaats van toepassing van de hierboven beschreven bijstelling lieten zien dat in alle gevallen een vergelijkbaar verband tussen endotoxineconcentratie en de betreffende gezondheidsvariabele gevonden.

\section{Resultaten}

Onderstaande resultaten hebben allen betrekking op de met het verspreidingsmodel berekende jaargemiddelde PM10 concentratie en de endotoxineconcentratie in de $\mathrm{PM}_{10}$ fractie. In het verspreidingsmodel is uitgegaan van warmte emissie. Berekende jaargemiddelde endotoxineconcentratie in de $\mathrm{PM}_{10}$ fractie kwamen sterk overeen met de berekende jaargemiddelde endotoxineconcentratie in de $\mathrm{PM}_{100}$ fractie, associaties met gezondheidsuitkomsten leveren dan ook voor $\mathrm{PM}_{100}$ vergelijkbare resultaten op (niet weergegeven).

\section{Serologie}

Deze analyses hebben betrekking op 2494 personen waarvan is vastgesteld of ze atopisch zijn (aanleg voor allergie hebben) op basis van serologisch onderzoek.

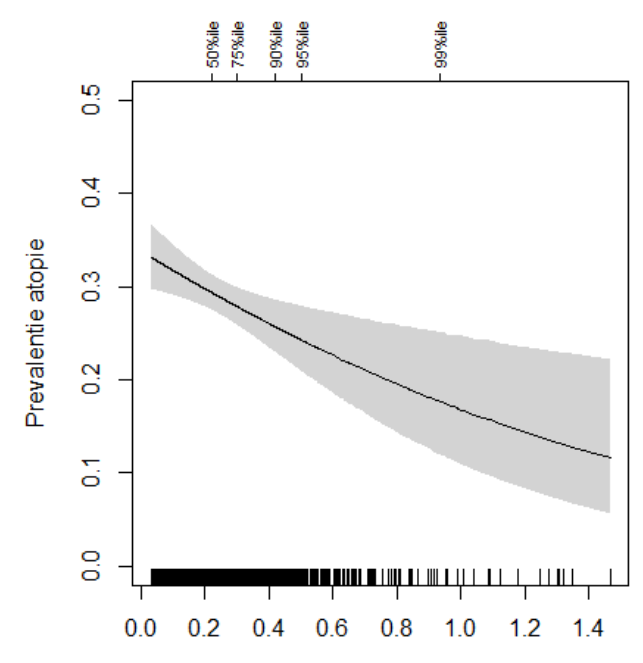

Dispersiemodel berekende jaargemiddelde $\left(\mathrm{EU} / \mathrm{m}^{\wedge} 3\right)$

Figuur 23. De relatie tussen voorkomen van atopie (aanleg voor allergie) en berekende endotoxine concentratie op het woonadres $(p=0,0037)$ gecorrigeerd voor leeftijd, geslacht, pakjaren roken, ooit gerookt, afkomstig van buiten VGO-gebied, opgegroeid op een boerenbedrijf.

De associatie tussen atopie en met verspreidingsmodellering berekende endotoxineconcentratie op het woonadres is in bovenstaande figuur gegeven. Een hogere endotoxineblootstelling is geassocieerd met een lagere prevalentie atopie. Bovenstaande figuur is berekend op basis van een zogenaamde 'spline' die het mogelijk maakt om ook niet-lineaire associaties te beschrijven. Een vergelijkbaar maar zwakker verband, in termen van zogenaamde 'model fit, is gevonden voor PM10.

Indien de analyse wordt beperkt tot personen die minimaal 5 jaar op hetzelfde adres hebben gewoond verandert de associatie vrijwel niet $(p=0,0057)$. De associatie op basis van berekende endotoxine concentraties is sterker dan op basis van de eerdere analyses in de VGO-studie die gebruik maakten 
van de afstand tot het eerste veehouderijbedrijf en de dichtheid van veehouderijbedrijven rond de woning voor zowel de analyse waarin alle gezondheidsonderzoekdeelnemers zijn meegenomen (respectievelijk $p=0,0245$ en 0,414 ) als de analyse waarin alleen personen die minimaal 5 jaar op hetzelfde adres hebben gewoond zijn meegenomen (respectievelijk 0,0647 en 0,188).

\section{Respiratoire klachten}

Voor de analyse met respiratoire klachten is gebruik gemaakt van de populatie die de korte vragenlijst heeft ingevuld en niet woonde/werkte op een boerderij ( $n=11$ 944). In de VGO-studie zijn statistisch significante verbanden gevonden voor drie specifieke symptomen (piepen op de borst al of niet in combinatie met andere verschijnselen). Deze drie symptomen bleken ook samen te hangen met de berekende endotoxineconcentratie op het woonadres evenals de dichtheid van het aantal veehouderijbedrijven in een straal van 1000 meter. De afstand tot het dichtstbijzijnde veehouderijbedrijf hangt in geen van de gevallen samen met piepen op de borst (al of niet in combinatie met andere symptomen). De PM10 concentratie op het woonadres bleek niet duidelijk samen te hangen met deze respiratoire symptomen.
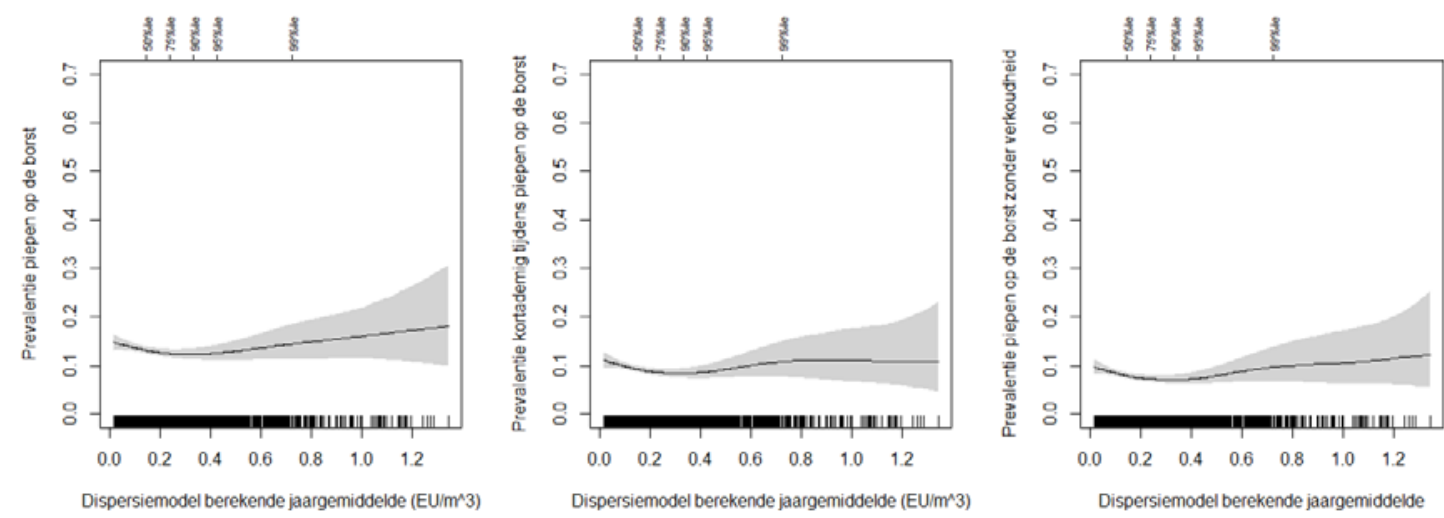

Figuur 24a-24c. Respiratoire symptomen, piepen op de borst, piepen op de borst met kortademigheid en piepen op de borst in afwezigheid van een verkoudheid in relatie tot de endotoxine concentratie op het woonadres en dichtheid van veehouderijbedrijven in een straal van $1000 \mathrm{~m}$ rond de woning (respectievelijk $p=0,0964 ; p=0,007, p=0.0024$ ), gecorrigeerd voor geslacht, leeftijd, huidig roken en eerder roken.

Alle hierboven beschreven verbanden met respiratoire symptomen werden alleen met een spline gevonden. Geen van de verbanden was statistisch significant met een lineair model. Voor andere klachten werden in het algemeen geen consistente verbanden gevonden. Voor huidig astma werd een negatieve associatie gevonden $(p=0,0401)$, dus een toename in endotoxineniveaus ging gepaard met een afname van astma prevalentie. Voor de verschillende piepen op de borst klachten was sprake van een afname in de prevalentie met toenemende endotoxineconcentratie en vervolgens een toename. Voor COPD werd een trend gevonden met de berekende endotoxine concentratie $(p=0,0575)$ en er was een significante, maar negatieve associatie met dagelijks hoesten en de gemodelleerde endotoxineconcentratie $(p=0,0083)$. In de eerdere analyses met de blootstellingsproxies in het VGOonderzoek zijn geen associaties met de dichtheid van bedrijven rond de woning gevonden, maar wel met de afstand tot het dichtstbijzijnde veehouderijbedrijf. 


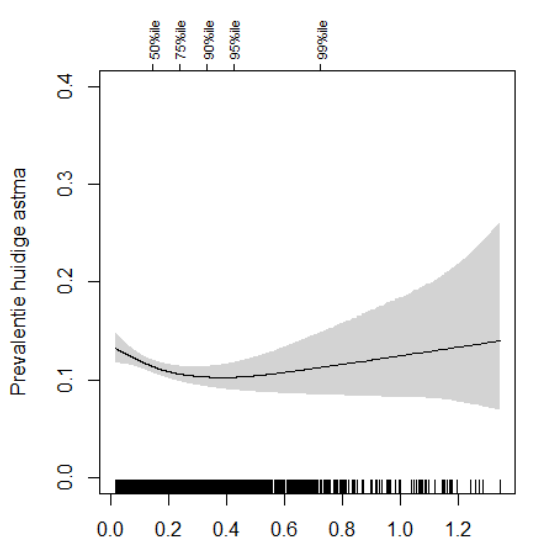

Dispersiemodel berekende jaargemiddelde $\left(E U / \mathrm{m}^{\wedge} 3\right)$

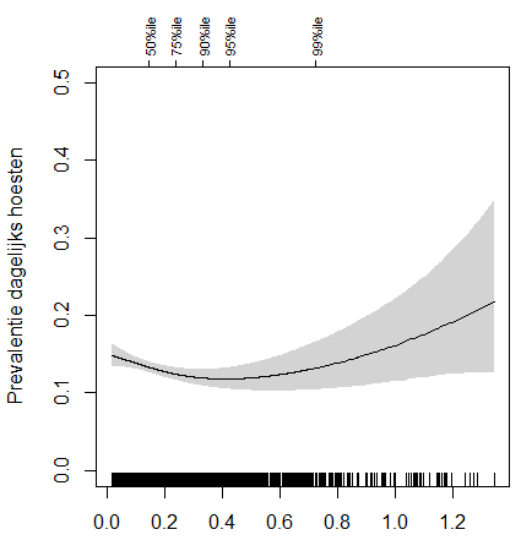

Dispersiemodel berekende jaargemiddelde $\left(E U / \mathrm{m}^{\wedge} 3\right)$

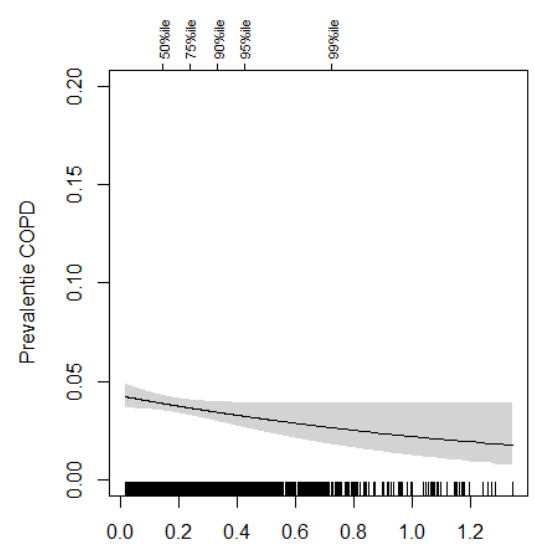

Dispersiemodel berekende jaargemiddelde $\left(E U / \mathrm{m}^{\wedge} 3\right)$

Figuur 25a-25c. Huidig astma, COPD en dagelijks hoesten in relatie tot de endotoxine concentratie op het woonadres $(p=0,0401$ respectievelijk $p=0,0575$ en $p=0,0083$ ) gecorrigeerd voor geslacht, leeftijd, huidig roken en eerder roken.

Er is ook onderzocht of symptomen vooral samenhangen met de endotoxineconcentratie op het woonadres bij mensen met COPD of astma. Dergelijke associaties zijn niet gevonden, maar door de geringe aantallen was het onderscheidend vermogen van deze analyses beperkt.

\section{Longfunctie}

De longfunctie is bij 2494 deelnemers aan het VGO-onderzoek bemeten met een resultaat dat aan de internationale kwaliteitscriteria voldeed. Gebruik is gemaakt van de longfunctie die is gemeten voorafgaand aan de reversibiliteitsmeting. Voor alle longfunctievariabelen werden zwakke negatieve associaties met de endotoxineconcentratie op het woonadres gevonden, alleen voor de FVC was deze statistisch significant, waarbij een verminderde longfunctie zichtbaar was bij hogere endotoxineniveaus. Voor de PM10 concentratie op het woonadres zijn geen statistisch significante associaties gevonden met de longfunctie. In de eerdere analyse zoals die in de VGO-rapportage is beschreven werden vergelijkbare resultaten gevonden, maar was de associatie met de MMEF statistisch significant. In de VGO-studie werden de sterkste verbanden gevonden met ammoniak. Op dagen dat de ammoniakblootstelling het hoogste was, werd een langere longfunctie gevonden. Een dergelijke analyse is met de endotoxineconcentratie niet uitgevoerd, er is geen betrouwbare informatie beschikbaar die de endotoxineconcentratie op verschillende tijdstippen beschrijft. Ook de validatiestudie laat zien dat met de verspreidingsmodellen de endotoxineconcentratie gedurende een korte periode niet adequaat berekend kan worden. 

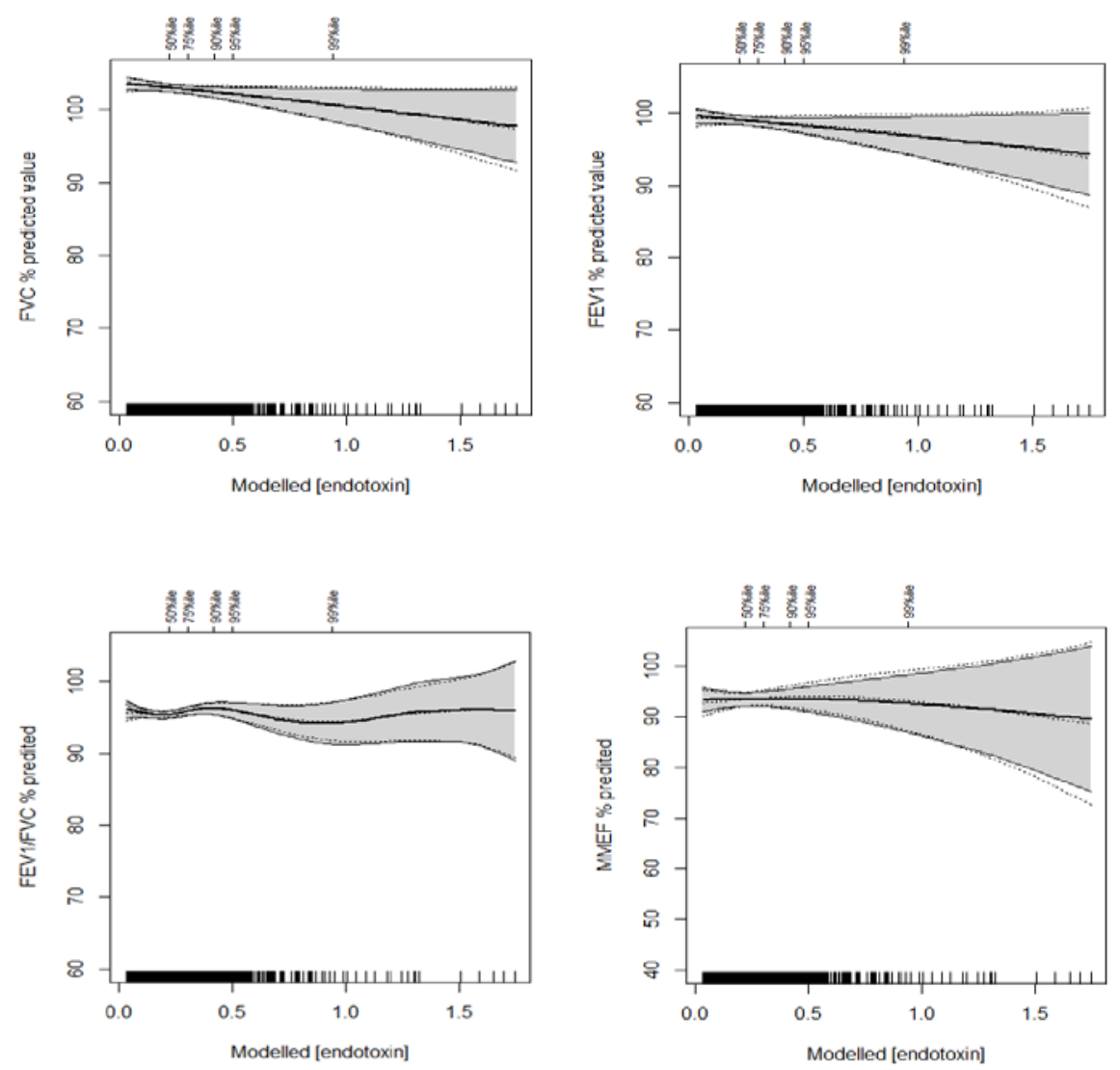

Figuur 26a-26d. Associaties tussen longfunctie en endotoxineconcentratie berekend op het woonadres voor een viertal longfunctievariabelen ( $F V C$ vitale capaciteit $p=0,0484, F E V_{1}$ één seconde volume $p=0,129, F E V_{1} / F V C$ Tiffeneau index $p=0,406$, MMEF mid-expiratoire flow $p=0,892$ ), gecorrigeerd voor leeftijd, lengte en geslacht (door berekening van residuen) en opgegroeid op een boerenbedrijf, pakjaren roken, voormalig roken, afkomstig van buiten VGO-gebied. De gestippelde lijnen laten de modelresultaten zien waarbij ook gecorrigeerd is voor week-gemiddelde $\mathrm{NH}_{3}\left(\mu \mathrm{g} / \mathrm{m}^{3}\right)$ niveaus voorafgaand aan de longfunctietest.

\section{Conclusies}

Her-analyse van de VGO medische onderzoeksgegevens voor atopie, gedefinieerd als sensibilisatie of aanwezigheid van antilichamen tegen algemeen voorkomende allergenen, luchtwegklachten en longfunctie met de berekende endotoxineconcentratie op het woonadres levert een aantal statistisch significante verbanden op. Van de 12 variabelen die eerder in de VGO studie zijn onderzocht (atopie (sensibilisatie tegen minstens één allergeen uit een panel milieu-allergenen of een verhoogd IgE niveau) (1)), longfunctie (4) respiratoire aandoeningen/symptomen (7)) waren er, uitgaande van de 'fit' van de modellen, 6 het sterkst geassocieerd met de endotoxineconcentratie in de lucht op het woonadres, 4 met dichtheid van veehouderijen rond de woning en 1 met de afstand tot de dichtstbijzijnde veehouderij en 1 met de PM10 concentratie in de lucht op het woonadres. In het kort betreft het de volgende verbanden:

- $\quad$ Er wordt een sterk en statistisch significant verband gevonden tussen atopie en de gemodelleerde endotoxine-concentratie op het woonadres van de deelnemers aan het VGO medisch onderzoek. Deze analyse bevestigt de eerder waargenomen beschermende effecten voor atopie bij omwonenden van veehouderijbedrijven, maar nu specifiek in relatie tot endotoxineconcentraties op het woonadres. 
- In de VGO-studie bleken meerdere respiratoire symptomen samen te hangen met de dichtheid van veehouderijbedrijven rond de woning (maar niet de afstand tot het dichtstbijzijnde veehouderijbedrijf). Het betrof onder meer piepen op de borst, piepen op de borst en kortademigheid, en piepen op de borst in afwezigheid van een verkoudheid. In deze heranalyse zijn de gevonden associaties (nu tussen respiratoire symptomen en berekende endotoxineconcentraties) in grote lijnen vergelijkbaar. De associaties tussen endotoxineblootstelling, piepen op de borst en piepen op de borst en benauwdheid waren sterker in vergelijking met de associaties die eerder in de VGO-studie beschreven zijn op basis van dichtheid van veehouderij rond de woning. De vorm van de associaties verschilt aanzienlijk. Analyses op basis van dichtheid van veehouderijbedrijven in een buffer rond de woning laten een toename zien van de klachtenprevalentie met toenemende dichtheid. Voor de endotoxine blijkt de prevalentie allereerst af te nemen met toenemende concentratie. Bij verdere verhoging van de concentratie neemt de klachtenprevalentie weer toe.

- De associaties tussen omgevingsconcentraties endotoxine en de longfunctie zijn in het algemeen relatief zwak. De richting en de vorm van de associaties zijn in grote lijnen vergelijkbaar met wat in het VGO-onderzoek is gevonden. In het VGO-onderzoek is daarnaast nog gevonden dat de longfunctie lager was op dagen met hoge ammoniakniveaus in de buitenlucht. In dit laatste geval was sprake van een veel sterker verband. Omdat met verspreidingsmodellen niet goed voorspeld kan worden op welk tijdstip de concentratie luchtverontreiniging (en dus ook endotoxine) is verhoogd, zijn geen verdere pogingen ondernomen om deze temporele associaties te onderzoeken met gemodelleerde endotoxineconcentraties.

De associaties tussen klachten en medicijngebruik en afstand van een veehouderijbedrijf/dichtheid van bedrijven rond de woning onder COPD-patiënten werden niet gereproduceerd voor endotoxineconcentraties op het woonadres, maar het onderscheidend vermogen van deze analyse is beperkt door het beperkte aantal personen dat in deze analyse is betrokken.

De PM10- en de endotoxineconcentratie op een bepaald punt wordt bepaald door een combinatie van meerdere variabelen, waaronder het aantal veehouderijen, maar ook de afstand tot veehouderijen, het type veehouderij, de omvang van het bedrijf (aantallen dieren), ruigheid van het terrein. Zowel LUR- als dispersiemodellering nemen de invloed van deze variabelen in meer of mindere mate mee. Eerdere analyses in het VGO onderzoek zijn gebaseerd het gebruik van enkele geïsoleerde variabelen (afstand tot de woning, dichtheid veehouderijbedrijven rond de woning) die de PM10-en endotoxineblootstelling maar ten dele verklaren. Dit speelt een rol bij de interpretatie van deze associaties op basis van gemodelleerde PM10- en endotoxineconcentraties in vergelijking met eerdere analyses in de VGO studie.

De endotoxine blootstelling is, uitgedrukt als jaargemiddelde endotoxineblootstelling, zelfs voor de allerhoogst blootgestelden, relatief laag en bedraagt enkele $\mathrm{EU} / \mathrm{m}^{3}$. Gegeven de kennis over effecten van endotoxine, lijkt het niet waarschijnlijk dat dergelijke lage endotoxineniveaus tot effecten leiden. Het is waarschijnlijker dat een hogere jaargemiddelde blootstelling indicatief is voor regelmatige kortdurende blootstelling aan niveaus van tientallen $\mathrm{EU} / \mathrm{m}^{3}$. Dergelijke niveaus komen op locaties met veel veehouderijbedrijven, afhankelijk van de precieze locatie, zo nu en dan tot regelmatig voor, afhankelijk van de specifieke meteorologische omstandigheden (windsnelheid, windrichting) en actuele emissies van omliggende bedrijven.

In de VGO-studie is wel een sterke, en plausibele, associatie gevonden tussen weekgemiddelde ammoniakniveaus in de lucht gedurende de meetperiode van het medisch onderzoek en de longfunctie. Deze associatie is niet onderzocht omdat met de verspreidingsmodellen concentraties 
gedurende relatief korte tijd op een specifieke datum niet goed kunnen worden voorspeld.

Verspreidingsmodellen geven accurater informatie als lange-termijngemiddelde concentraties worden voorspeld. Ook zijn associaties tussen endotoxineblootstelling en het voorkomen van longontsteking niet onderzocht. Omdat dit een omvangrijke exercitie is, gezien de omvang van de onderzoekspopulatie (meer dan 90000 personen), is dit effect niet opgenomen in deze studie. Het lijkt echter relevant de associatie tussen endotoxineblootstelling en longontsteking wel nader te onderzoeken, gezien de consistente associaties in de VGO-studie tussen pluimvee- en geitenhouderijen en longontsteking over meerdere jaren.

Theoretisch kunnen sterkere associaties worden verwacht bij gebruik van een blootstellingsmaat voor de omgevingsblootstelling die voor de ontwikkeling of verergering van gezondheidseffecten relevant is (endotoxine), in vergelijking met ruwe schattingen (of zogenaamde 'proxies') voor die blootstelling zoals de afstand van het woonadres tot veehouderijen of de dichtheid van veehouderijbedrijven rond de woning zoals die eerder in het VGO onderzoek zijn gebruikt. Dit ook tegen de achtergrond dat deze proxies de endotoxineconcentratie in de omgeving maar ten dele verklaren. ${ }^{21}$ Echter al eerder is aangegeven dat de gemodelleerde endotoxineconcentratie de werkelijke endotoxineconcentratie op het woonadres om meerdere redenen niet perfect hoeft te schatten, onder meer omdat verondersteld wordt dat de emissie constant is over de tijd, emissie in grote lijnen vergelijkbaar is tussen bedrijven en de gehanteerde informatie over locaties van bedrijven, aantallen dieren, etc., niet zonder fouten is gemeten. Aan al deze voorwaarden wordt niet voldaan en hierdoor zullen afwijkingen bestaan tussen de gemodelleerde en de werkelijke endotoxineconcentratie die van locatie tot locatie in richting en omvang kunnen verschillen. Dergelijke afwijkingen leiden in de meeste gevallen tot onderschatting van blootstellings-responsrelaties in de hier gepresenteerde epidemiologische analyses en kunnen ook tot verandering in de vorm van de relatie leiden, afhankelijk van de precieze foutenstructuur. ${ }^{35}$ Daarbij komt dat ook onbekend is of eventuele effecten door blootstelling aan endotoxine het gevolg zijn van chronische of acute blootstelling. De gevonden associaties moeten tegen deze achtergrond worden geïnterpreteerd.

Samenvattend zijn vergelijkbare en vaak sterkere associaties gevonden voor endotoxineconcentraties in de lucht op het woonadres en gezondheidseffecten. Het sterke verband met sensibilisatie is opmerkelijk. Het feit dat associaties vaak sterker waren in termen van 'model fit' voor endotoxine in vergelijking met de PM10 concentratie op het woonadres, ondersteunt de hypothese dat endotoxine een relevante merker is van vee gerelateerde blootstelling, voorspellend voor gezondheidseffecten. Het is mogelijk dat endotoxine zelf effecten veroorzaakt, maar stof van veehouderijen bevat andere microbiële componenten die vergelijkbare effecten kunnen veroorzaken. Ook geeft dit aan dat primair fijnstof, geëmitteerd door veehouderijbedrijven, mogelijk specifieke effecten heeft. Endotoxinen worden niet geëmitteerd door verkeer en de meeste industriële bronnen.

Veehouderijen emitteren micro-organismen en micro-organisme gerelateerde toxinen. Endotoxine is een belangrijke pro-inflammatoire component waarvan bekend is dat na inhalatie een reeks van, dosis afhankelijke, gezondheidseffecten op kunnen treden. Endotoxinen zijn vooral afkomstig van Gramnegatieve bacteriën. Maar veehouderijen emitteren een mengsel van uiteenlopende microorganismen. Gram-positieve bacteriën en schimmels en hun toxinen worden ook in belangrijke mate door veehouderij geëmitteerd. Zo worden ook stoffen zoals muraminezuur en $ß(1 \rightarrow 3)$ glucanen en $ß(1 \rightarrow 6)$ glucanen geëmitteerd. Deze stoffen zijn afkomstig van respectievelijk Gram-positieve bacteriën en schimmels of plantaardig materiaal, en kunnen ook pro-inflammatoire effecten veroorzaken. Enkele van deze stoffen zijn ook geassocieerd met (acute) respiratoire effecten bij stof afkomstig van veehouderijen. Blootstelling aan endotoxinen kan mogelijke (respiratoire) effecten bij omwonenden 
verklaren, maar moet ook gezien worden als aanwijzing dat sprake is van potentiële microbiologische blootstelling afkomstig van veehouderijbedrijven.

Het is belangrijk op te merken dat de door de Gezondheidsraad voorgestelde grenswaarden (90 en 30 $\mathrm{EU} / \mathrm{m}^{3}$ voor respectievelijk de werkomgeving en voor omwonenden van veehouderijen), gebaseerd zijn op een acuut effect op de longfunctie. ${ }^{617} 19$ In het systematisch literatuuronderzoek zijn geen studies geïdentificeerd die een versnelde longfunctiedaling door lange-termijn (chronische) lage blootstelling aan endotoxine hebben onderzocht. Een andere systematisch literatuuronderzoek naar het lange-termijn effect van hogere endotoxineconcentraties op de longfunctie liet slechts beperkt bewijs zien van een dergelijk effect. ${ }^{36}$ Dit lijkt consistent met de ruimtelijke analyses voor de VGO populatie, zoals die eerder zijn gepubliceerd en specifiek voor de associaties met endotoxine zijn opgenomen in deze studie. ${ }^{37}$ De literatuurstudie geeft wel aanwijzing voor korte-termijneffecten op de longfunctie en voor associaties met luchtwegklachten. De uitkomsten voor respiratoire symptomen en longfunctie lijken daarmee op hoofdlijnen overeen te komen met indicaties vanuit de literatuur. 


\section{Referenties}

1. Maassen CBM, van Duijkeren E, van Duynhoven $Y$, et al. Infectierisico's van de veehouderij voor omwonenden. Bilthoven: RIVM, 2012.

2. Heederik D, Yzermans J. Mogelijke effecten van intensieve veehouderij op de gezondheid van omwonenden. Utrecht, 2011.

3. Maassen K, Smit LA, Wouters I, et al. Veehouderij en gezondheid omwonenden. Bilthoven: RIVM, IRAS UU, WUR, NIVEL, 2016.

4. Hagenaars TJ, Hoeksma P, de Roda Husman A, et al. Veehouderij en Gezondheid omwonenden (aanvullende studies) [in Dutch, summary in English]. Bilthoven: RIVM, 2017.

5. Smit LA, Boender GJ, de Steenhuijsen Piters WAA, et al. Increased risk of pneumonia in residents living near poultry farms: does the upper respiratory tract microbiota play a role? . Pneumonia 2017;9(3) doi: 10.1186/s41479-017-0027-0

6. Health Council of the Netherlands. Health risks associated with livestock farms. The Hague: Gezondheidsraad, 2012.

7. Winkel A, Wouters I, Aarnink AJA, et al. Emissies van endotoxine uit de veehouderij: een literatuurstudie voor ontwikkeling van een toetsingskader. Wageningen: WUR, 2014.

8. Ogink NWM, Erbrink $H$, Heederik $D$, et al. Emissies van endotoxine uit de veehouderij: emissiemetingen en verspreidingsmodellering Wageningen: WUR, 2016.

9. Winkel A, Erbrink H, Wouters I, et al. Emissies van endotoxinen uit de veehouderij: eindrapport endotoxine metingen. Wageningen: Livestock Research Rapport, 2018.

10. Maassen CB, Smit LA, Wouters I, et al. Veehouderij en Gezondheid [in Dutch, summary in English]. Bilthoven: RIVM, 2016.

11. Borlee F, Yzermans CJ, Krop EJM, et al. Residential proximity to livestock farms is associated with a lower prevalence of atopy. Occupational and environmental medicine 2018;75(6):453-60. doi: 10.1136/oemed-2017-104769 [published Online First: 2018/05/02]

12. Borlee F, Yzermans CJ, Aalders B, et al. Air Pollution from Livestock Farms Is Associated with Airway Obstruction in Neighboring Residents. Am J Respir Crit Care Med 2017;196(9):1152-61. doi: 10.1164/rccm.201701-00210C [published Online First: 2017/05/11]

13. Borlee F, Yzermans CJ, Krop E, et al. Spirometry, questionnaire and electronic medical record based COPD in a population survey: Comparing prevalence, level of agreement and associations with potential risk factors. PloS one 2017;12(3):e0171494. doi: 10.1371/journal.pone.0171494

14. Erbrink H. Turbulent diffusion from tall stacks. The use of advanced boundary layer meteorological parameters in Gaussian dispersion model "STACKS", 1995.

15. van Ham J, Duijm J, Erbrink $H$, et al. Revision of the Netherlands National Model for short range dispersion of air pollutants. Int J Environ Pollution 1998;8:3-6.

16. Infomil. "Het paarse boekje": Nieuw nationaal model. Verslag van onderzoek van de Projectgroep Revisie Nationaal Model. Den Haag, 1998.

17. Castellan RM, Olenchock SA, Kinsley KB, et al. Inhaled endotoxin and decreased spirometric values. An exposure-response relation for cotton dust. The New England journal of medicine 1987;317(10):605-10.

18. Kline JN, Cowden JD, Hunninghake GW, et al. Variable airway responsiveness to inhaled lipopolysaccharide. American journal of respiratory and critical care medicine 1999;160(1):297303. doi: 10.1164/ajrccm.160.1.9808144 [published Online First: 1999/07/03]

19. Health Council of the N. Endotoxins. Health-based recommended occupational exposure limit. The Hague: Health Council of the Netherlands, 2010.

20. TAUW. Uitwerking gebiedgericht model fijnstof Nederweert., 2017.

21. de Rooij MM, Heederik D, van Nuenen EJHM, et al. Spatial variation of endotoxin concentrations measured in ambient PM10 in a livestock dense area: implementation of land use regression approach. Environmental health perspectives 2018;126(1):017003-1-13.

22. Smid T, Heederik D, Houba R, et al. Dust- and endotoxin-related respiratory effects in the animal feed industry. The American review of respiratory disease 1992;146(6):1474-9. 
23. Post W, Heederik D, Houba R. Decline in lung function related to exposure and selection processes among workers in the grain processing and animal feed industry. Occupational and environmental medicine 1998;55(5):349-55.

24. Proper KI, Singh AS, Van Mechelen W, et al. Sedentary behaviors and health outcomes among adults: a systematic review of prospective studies. American Journal of Preventive Medicine 2011;40(2):174-82.

25. Hoopmann M, Hehl O, Neisel F, et al. Zusammenhang zwischen Bioaerosolen aus Tierhaltungsanlagen und asthmatischen Symptomen bei Kindern. Das Gesundheitswesen 2006;68(08/09):575-84.

26. Horick N, Weller E, Milton DK, et al. Home endotoxin exposure and wheeze in infants: correction for bias due to exposure measurement error. Environmental health perspectives 2006;114(1):135-40. [published Online First: 2006/01/06]

27. Portengen L, Preller L, Tielen $M$, et al. Endotoxin exposure and atopic sensitization in adult pig farmers. The Journal of allergy and clinical immunology 2005;115(4):797-802. doi: 10.1016/j.jaci.2004.11.046 [published Online First: 2005/04/05]

28. Smit LA, Heederik D, Doekes G, et al. Occupational endotoxin exposure reduces the risk of atopic sensitization but increases the risk of bronchial hyperresponsiveness. International archives of allergy and immunology 2010;152(2):151-8. doi: 10.1159/000265536

29. Braun-Fahrlander C, Riedler J, Herz U, et al. Environmental exposure to endotoxin and its relation to asthma in school-age children. The New England journal of medicine 2002;347(12):869-77. doi: 10.1056/NEJMoa020057 [published Online First: 2002/09/20]

30. Schram-Bijkerk D, Doekes G, Douwes J, et al. Bacterial and fungal agents in house dust and wheeze in children: the PARSIFAL study. Clinical and experimental allergy : journal of the British Society for Allergy and Clinical Immunology 2005;35(10):1272-8. doi: 10.1111/j.13652222.2005.02339.x [published Online First: 2005/10/22]

31. Sordillo JE, Hoffman EB, Celedon JC, et al. Multiple microbial exposures in the home may protect against asthma or allergy in childhood. Clinical and experimental allergy : journal of the British Society for Allergy and Clinical Immunology 2010;40(6):902-10. doi: 10.1111/j.13652222.2010.03509.x [published Online First: 2010/04/24]

32. Preller L, Heederik D, Boleij JS, et al. Lung function and chronic respiratory symptoms of pig farmers: focus on exposure to endotoxins and ammonia and use of disinfectants: Occup Environ Med 1995 Oct ;52(10):654-660.

33. Smit LA, Heederik D, Doekes G, et al. Endotoxin exposure, CD14 and wheeze among farmers: a gene-environment interaction. Occupational and environmental medicine 2011 doi: 10.1136/oem.2010.060038 [published Online First: 2011/03/11]

34. Smit LA, Heederik D, Doekes $G$, et al. Ex vivo cytokine release reflects sensitivity to occupational endotoxin exposure. The European respiratory journal 2009;34(4):795-802. doi: 10.1183/09031936.00161908 [published Online First: 2009/04/10]

35. Armstrong BG. The effects of measurement errors on relative risk regressions. Am J Epidemiol 1990;132(6):1176-84.

36. Bolund AC, Miller MR, Sigsgaard T, et al. The effect of organic dust exposure on long-term change in lung function: a systematic review and meta-analysis. Occupational and environmental medicine 2017;74(7):531-42. doi: 10.1136/oemed-2016-103963 [published Online First: 2017/04/14]

37. Borlee F, Yzermans CJ, Aalders B, et al. Air Pollution from Livestock Farms is Associated with Airway Obstruction in Neighboring Residents. American journal of respiratory and critical care medicine 2017 doi: 10.1164/rccm.201701-00210C [published Online First: 2017/05/11]

38. Mosquera J, Emous RA, Winkel A, et al. Fijnstofemissies uit stallen: (groot)ouderdieren van vleeskuikens. . Lelystad: WUR, 2009.

39. Mosquera J, Hol JMG, Winkel A, et al. Fijnstofemissies uit stallen: nertsen. Lelystad: WUR, 2011. 40. Mosquera J, Hol JMG, Winkel A, et al. Fijnstofemissies uit stallen: melkvee. Lelystad: WUR, 2010. 
41. Mosquera J, Hol JMG, Winkel A, et al. Fijnstofemissies uit stallen: vleesvarkens. Lelystad: WUR, 2010.

42. Mosquera J, Hol JMG, Winkel A, et al. Fijnstofemissies uit stallen: dragende zeugen. . Lelystad: WUR, 2010.

43. Mosquera J, Winkel A, Dousma F, et al. Fijnstofemissies uit stallen: Leghennen in scharrelhuisvesting. lelystad: WUR, 2009.

44. Mosquera J, Winkel A, Kwikkel RK, et al. fijnstofemissies uit stallen: vleeskalkoenen. Lelystad: WUR, 2009.

45. Winkel A, Mosquera J, Hol JMG, et al. Fijnstofemissies uit stallen: leghennen in volierehuisvesting. Lelystad: WUR, 2009.

46. Winkel A, Mosquera J, Hol JMG, et al. Fijnstofemissie uit stallen: biggen. Lelystad: WUR, 2010.

47. Winkel A, Mosquera J, Kwikkel RK, et al. Fijnstofemissies uit stallen: vleeskuikens. Lelystad: WUR, 2009.

48. Winkel A, Mosquera J, Koerkamp PWGG, et al. Emissions of particulate matter from animal houses in the Netherlands. Atmos Environ 2015;111:202-12. doi: 10.1016/j.atmosenv.2015.03.047

49. Adell E, Calvet S, Torres AG, et al. Particulate Matter Concentrations and Emissions in Rabbit Farms. World Rabbit Sci 2012;20(1):1-11. doi: 10.4995/wrs.2012.1035

50. Aarnink AJA, Mosquera J, Cambra Lopez M, et al. Emissie van stof en ziektekiemen uit melkgeitenstallen. . Lelystad: WUR, 2012.

51. Aarnink AJA, Roest HJ, Huis in 't Veld JWH, et al. Emissies van stof en ziektekiemen uit melkgeitenstallen: aanvullende metingen. . Lelystad: WUR, 2014.

52. De Rooij MM, Van Leuken J, Swart A, et al. Synthesis on spatial dimensions of $Q$ fever epidemics. Zoonosis Public Health 2019; 66: 14-25.

53. Reynolds SJ, Thorne PS, Donham KJ, et al. Comparison of endotoxin assays using agricultural dusts. AlHA journal : a journal for the science of occupational and environmental health and safety 2002;63(4):430-8. [published Online First: 2002/12/19]

54. Basinas I, Sigsgaard T, Heederik D, et al. Exposure to inhalable dust and endotoxin among Danish livestock farmers: results from the SUS cohort study. J Environ Monitor 2012;14(2):604-14. doi: 10.1039/c1em10576k

55. Samadi S, Wouters IM, Houben R, et al. Exposure to inhalable dust, endotoxins, beta(1->3)-glucans, and airborne microorganisms in horse stables. The Annals of occupational hygiene 2009;53(6):595-603. doi: 10.1093/annhyg/mep040 [published Online First: 2009/06/30]

56. Siegers EW, Anthonisse M, van Eerdenburg FJCM, et al. Effect of ionization, bedding, and feeding on air quality in a horse stable. J Vet Intern Med 2018;32(3):1234-40. doi: 10.1111/jvim.15069

57. Kateman E, Heederik D, Pal TM, et al. Relationship of airborne microorganisms with the lung function and leucocyte levels of workers with a history of humidifier fever. Scand $\mathrm{J}$ Work Environ Health 1990;16(6):428-33.

58. Dahlqvist $M$, Johard $U$, Alexandersson $R$, et al. Lung function and precipitating antibodies in low exposed wood trimmers in Sweden. American journal of industrial medicine 1992;21(4):54959. [published Online First: 1992/01/01]

59. Sprince NL, Thorne PS, Popendorf W, et al. Respiratory symptoms and lung function abnormalities among machine operators in automobile production. American journal of industrial medicine 1997;31(4):403-13. [published Online First: 1997/04/01]

60. Mahar S. Worker Health in refuse-derived fuel plants, a five-year followup. Arhiv za Higijenu Rada I Toksikologiju/Archives of Industrial Hygiene and Toxicology 2002;53(3):191-96.

61. Heldal KK, Eduard W. Associations between acute symptoms and bioaerosol exposure during the collection of household waste. American journal of industrial medicine 2004;46(3):253-60. doi: 10.1002/ajim.20058 [published Online First: 2004/08/13]

62. Sigsgaard T, Jensen LD, Abell A, et al. Endotoxins isolated from the air of a Danish paper mill and the relation to change in lung function: an 11-year follow-up. American journal of industrial medicine 2004;46(4):327-32. 
63. Rabinovitch N, Liu AH, Zhang L, et al. Importance of the personal endotoxin cloud in school-age children with asthma. The Journal of allergy and clinical immunology 2005;116(5):1053-7. doi: 10.1016/j.jaci.2005.08.045 [published Online First: 2005/11/09]

64. Rusca S, Charriere N, Droz PO, et al. Effects of bioaerosol exposure on work-related symptoms among Swiss sawmill workers. International archives of occupational and environmental health 2008;81(4):415-21. doi: 10.1007/s00420-007-0228-6 [published Online First: 2007/08/07]

65. Dang B, Chen L, Mueller C, et al. Ocular and respiratory symptoms among lifeguards at a hotel indoor waterpark resort. J Occup Environ Med 2010;52(2):207-13. doi: 10.1097/JOM.0b013e3181cf00d5 [published Online First: 2010/02/06]

66. Heldal KK, Madso L, Eduard W. Airway inflammation among compost workers exposed to actinomycetes spores. Annals of agricultural and environmental medicine : AAEM 2015;22(2):253-8. doi: 10.5604/12321966.1152076 [published Online First: 2015/06/23]

67. Zock JP, Hollander A, Heederik D, et al. Acute lung function changes and low endotoxin exposures in the potato processing industry. American journal of industrial medicine 1998;33(4):384-91. [published Online First: 1998/03/26]

68. Mandryk J, Alwis KU, Hocking AD. Effects of personal exposures on pulmonary function and workrelated symptoms among sawmill workers. The Annals of occupational hygiene 2000;44(4):281-9. [published Online First: 2000/06/01]

69. Wouters IM, Hilhorst SK, Kleppe $\mathrm{P}$, et al. Upper airway inflammation and respiratory symptoms in domestic waste collectors. Occupational and environmental medicine 2002;59(2):106-12. [published Online First: 2002/02/19]

70. Fransman W, McLean D, Douwes J, et al. Respiratory symptoms and occupational exposures in New Zealand plywood mill workers. The Annals of occupational hygiene 2003;47(4):287-95. [published Online First: 2003/05/27]

71. Kennedy SM, Copes R, Bartlett $\mathrm{KH}$, et al. Point-of-sale glass bottle recycling: indoor airborne exposures and symptoms among employees. Occupational and environmental medicine 2004;61(7):628-35. [published Online First: 2004/06/23]

72. Smit LA, Spaan S, Heederik D. Endotoxin exposure and symptoms in wastewater treatment workers. American journal of industrial medicine 2005;48(1):30-9. doi: 10.1002/ajim.20176 [published Online First: 2005/06/09]

73. Widmeier S, Bernard A, Tschopp A, et al. Surfactant protein A, exposure to endotoxin, and asthma in garbage collectors and in wastewater workers. Inhal Toxicol 2007;19(4):351-60. doi: 10.1080/08958370601144456 [published Online First: 2007/03/17]

74. Renstrom $A$, Olsson $M$, Hedren $M$, et al. Pet shop workers: exposure, sensitization, and workrelated symptoms. Allergy 2011;66(8):1081-7. doi: 10.1111/j.1398-9995.2011.02591.x [published Online First: 2011/04/06]

75. Schlunssen V, Madsen AM, Skov S, et al. Does the use of biofuels affect respiratory health among male Danish energy plant workers? Occupational and environmental medicine 2011;68(7):46773. doi: 10.1136/oem.2009.054403 [published Online First: 2010/11/26]

76. Meza F, Chen L, Hudson N. Investigation of respiratory and dermal symptoms associated with metal working fluids at an aircraft engine manufacturing facility. American journal of industrial medicine 2013;56(12):1394-401. doi: 10.1002/ajim.22253 [published Online First: 2013/10/15]

77. Shiryaeva O, Aasmoe L, Straume B, et al. Respiratory effects of bioaerosols: exposure-response study among salmon-processing workers. American journal of industrial medicine 2014;57(3):276-85. doi: 10.1002/ajim.22281 [published Online First: 2013/12/07]

78. Schiffman SS, Studwell CE, Landerman LR, et al. Symptomatic effects of exposure to diluted air sampled from a swine confinement atmosphere on healthy human subjects. Environmental health perspectives 2005;113(5):567-76.

79. Delfino RJ, Staimer N, Tjoa T, et al. Relations of exhaled nitric oxide and FEV1 to personal endotoxin exposure in schoolchildren with asthma. Occupational and environmental medicine 2015;72(12):830-6. doi: 10.1136/oemed-2014-102651 [published Online First: 2015/06/18] 
80. Kawamoto MM, Garabrant DH, Held J, et al. Respiratory effects of cotton dust exposure in the cotton garnetting industry. American journal of industrial medicine 1987;11(5):505-15. [published Online First: 1987/01/01]

81. Mandryk J, Alwis KU, Hocking AD. Work-related symptoms and dose-response relationships for personal exposures and pulmonary function among woodworkers. American journal of industrial medicine 1999;35(5):481-90. [published Online First: 1999/04/23]

82. Cyprowski M, Sobala W, Buczynska A, et al. Endotoxin exposure and changes in short-term pulmonary function among sewage workers. Int J Occup Med Environ Health 2015;28(5):80311. doi: 10.13075/ijomeh.1896.00460 [published Online First: 2015/08/01]

83. Ghani N, Khalid A, Tahir A. Cross-sectional study on the endotoxin exposure and lung function impairment in the workers of textile industry near Lahore, Pakistan. J Pak Med Assoc 2016;66(7):803-14. [published Online First: 2016/07/19]

84. Hoopmann M, Hehl O, Neisel F, et al. [Associations between bioaerosols coming from livestock facilities and asthmatic symptoms in children]. Gesundheitswesen 2006;68(8-9):575-84. doi: 10.1055/s-2006-926987 [published Online First: 2006/10/14]

85. Ramagopal M, Wang Z, Black K, et al. Improved exposure characterization with robotic (PIPER) sampling and association with children's respiratory symptoms, asthma and eczema. Journal of exposure science \& environmental epidemiology 2014;24(4):421-7. doi: 10.1038/jes.2014.27 [published Online First: 2014/05/08]

86. Lai PS, Sheehan WJ, Gaffin JM, et al. School Endotoxin Exposure and Asthma Morbidity in Inner-city Children. Chest 2015;148(5):1251-58. doi: 10.1378/chest.15-0098 [published Online First: 2015/06/19]

87. Bose S, Rivera-Mariani F, Chen R, et al. Domestic exposure to endotoxin and respiratory morbidity in former smokers with COPD. Indoor air 2016;26(5):734-42. doi: 10.1111/ina.12264 [published Online First: 2015/11/09] 


\section{Appendix 1. Emissiegegevens}

\section{Tabel A.1.1. Basistabel emissie kenmerken ten behoeve van endotoxine modellering}

De lijst met emissiefactoren voor $\mathrm{PM}_{10}$ welke regelmatig online gepubliceerd wordt door het Ministerie van Infrastructuur en Milieu op:

https://www.rijksoverheid.nl/documenten/publicaties/2017/03/15/emissiefactoren-fijn-stof-voorveehouderij-2017, vormt de basis voor de tabel met emisse kenmerken voor endotoxine modellering. Deze lijst met emmissiefactoren voor $\mathrm{PM}_{10}$ is tot stand gekomen op basis van een onderzoeksprogramma "Actualisering emissie-factoren fijn stof" uitgevoerd door Wageningen Livestock Research tussen circa 2007 en 2012. Uit dit onderzoeksprogramma is een reeks van tien rapportages gepubliceerd die ook voor deze rapportage zijn gebruikt. ${ }^{38-47}$ De resultaten uit dit onderzoeksprogramma zijn verder geanalyseerd en gezamenlijk gepubliceerd in een 'peer review' wetenschappelijk tijdschrift. ${ }^{48}$

Voor de modellering van endotoxine zijn aanvullende gegevens nodig. Zo wordt voor endotoxine niet alleen de $\mathrm{PM}_{10}$ fractie, maar ook de grotere deeltjes fractie tot $\mathrm{PM}_{100}$ betrokken in de modellering. Daarom is de tabel aangevuld met:

\section{1) Factor $\mathbf{P M}_{100} / \mathbf{P M}_{10}$}

De verhouding tussen $\mathrm{PM}_{100}$ en $\mathrm{PM}_{10}$ verkregen uit het eerdere onderzoeksprogramma, waarmee $\mathrm{PM}_{100}$ emissies afgeleid kunnen worden.

2) Endotoxine gehalte in $\mathrm{PM}_{10}$

Het endotoxine gehalte (EU per $\mathrm{mg}$ ) in de $\mathrm{PM}_{10}$ fractie op basis van metingen of afgeleid uit de literatuur (voor details zie de tabel)

3) Endotoxine gehalte in $\mathbf{P M}_{100}$

Het endotoxine gehalte (EU per $\mathrm{mg}$ ) in de $\mathrm{PM}_{100}$ fractie op basis van metingen of afgeleid uit de literatuur (voor details zie de tabel)

4) Gefit endotoxine gehalte in $\mathrm{PM}_{100}$

Het endotoxine gehalte (EU per $\mathrm{mg}$ ) in de $\mathrm{PM}_{100}$ fractie gebruikt in de modellering gefit op basis van de uit de gemeten of afgeleide endotoxine gehalten en de deeltjesgrootte verdeling (voor details zie tekst) 


\begin{tabular}{|c|c|c|c|c|c|c|c|c|c|c|}
\hline \multirow[t]{2}{*}{$\begin{array}{l}\text { Rav } \\
\text { code }\end{array}$} & \multirow[t]{2}{*}{ Beschrijving } & \multicolumn{2}{|c|}{ Emissie $\mathrm{PM}_{10}$} & \multicolumn{2}{|l|}{$\begin{array}{l}\text { Factor } \\
\mathrm{PM}_{100} / \mathrm{PM}_{10}\end{array}$} & \multicolumn{2}{|c|}{$\begin{array}{l}\text { Gemeten endotoxine } \\
\text { gehalte in } \mathrm{PM}_{100}\end{array}$} & \multicolumn{2}{|c|}{$\begin{array}{l}\text { Gemeten endotoxine } \\
\text { gehalte in } \mathrm{PM}_{10}\end{array}$} & \multirow{2}{*}{$\begin{array}{l}\text { Fit } \\
\text { endotoxine } \\
\text { gehalte in } \\
\text { PM100* }^{*} \\
{[E U / m g]}\end{array}$} \\
\hline & & $\begin{array}{l}\text { [g/dpl. } \\
\text { per jr.] }\end{array}$ & Toelichting & Factor & Toelichting & {$[\mathrm{EU} / \mathrm{mg}]$} & Toelichting & {$[\mathrm{EU} / \mathrm{mg}]$} & Toelichting & \\
\hline A1 & Melk- en kalfkoeien ouder dan 2 jaar & 148 & EFSvV: G & 16.67 & [4] & 815 & G: [6] & 646 & G: [6] & 793 \\
\hline$A 2$ & Zoogkoeien ouder dan 2 jaar & 86 & EFSvV: A & 16.67 & $=\mathrm{A} 1$ & 815 & $=\mathrm{A} 1$ & 646 & $=\mathrm{A} 1$ & 793 \\
\hline A3 & Vrouwelijk jongvee tot 2 jaar & 38 & EFSvV: A & 16.67 & $=\mathrm{A} 1$ & 815 & $=\mathrm{A} 1$ & 646 & $=\mathrm{A} 1$ & 793 \\
\hline A4 & Vleeskalveren tot circa 8 maanden & 33 & EFSvV: A & 16.67 & $=\mathrm{A} 1$ & 815 & $=\mathrm{A} 1$ & 646 & $=\mathrm{A} 1$ & 793 \\
\hline A6 & Vleesstieren en ov. vleesv. van ca. 8 tot $24 \mathrm{mnd}$ & 170 & EFSvV: A & 16.67 & $=\mathrm{A} 1$ & 815 & $=\mathrm{A} 1$ & 646 & $=\mathrm{A} 1$ & 793 \\
\hline A7 & Fokstieren en overig rundvee ouder dan 2 jaar & 170 & EFSvV: A & 16.67 & $=\mathrm{A} 1$ & 815 & $=\mathrm{A} 1$ & 646 & $=\mathrm{A} 1$ & 793 \\
\hline B1 & Schapen ouder dan 1 jaar, inclusief lammeren tot $45 \mathrm{~kg}$ & --- & --- & --- & --- & --- & --- & --- & --- & --- \\
\hline $\mathrm{C} 1$ & Geiten ouder dan 1 jaar & 47 & [1] & 2.93 & [5] & 3308 & L: [7] & 2504 & L: [7] & 3116 \\
\hline $\mathrm{C} 2$ & Opfokgeiten van 61 dagen tot en met één jaar & 25 & [1] & 2.93 & $=\mathrm{C} 1$ & 3308 & $=\mathrm{C} 1$ & 2504 & $=\mathrm{C} 1$ & 3116 \\
\hline C3 & Opfokgeiten en afmestlammeren tot en met 60 dagen & 25 & [1] & 2.93 & $=\mathrm{C} 1$ & 3308 & $=\mathrm{C} 1$ & 2504 & $=\mathrm{C} 1$ & 3116 \\
\hline D1.1 & Biggenopfok (gespeende biggen) & 74 & EFSvV: G & 3.23 & [4] & 4091 & G: [6] & 2641 & G: [6] & 4122 \\
\hline $\mathrm{D} 1.2$ & Kraamzeugen (incl. biggen tot spenen) & 160 & EFSvV: A & 3.13 & $=\mathrm{D} 1.3$ & 1813 & $=\mathrm{D} 1.3$ & 1415 & $=\mathrm{D} 1.3$ & 1795 \\
\hline D1.3 & Guste en dragende zeugen & 175 & EFSvV: G & 3.13 & {$[4]$} & 1813 & G: [6] & 1415 & G: [6] & 1795 \\
\hline $\mathrm{D} 2$ & Dekberen, 7 maanden en ouder & 180 & EFSvV: A & 3.13 & $=\mathrm{D} 1.3$ & 1813 & $=\mathrm{D} 1.3$ & 1415 & $=\mathrm{D} 1.3$ & 1795 \\
\hline D3 & Vleesvarkens, opfokberen en opfokzeugen & 153 & EFSvV: G & 3.13 & [4] & 3847 & G: [6] & 2392 & G: [6] & 3904 \\
\hline D4 & Add. technieken (emissiereductie ammoniak) & --- & --- & --- & --- & --- & --- & --- & --- & --- \\
\hline E1 & Opfokhennen en hanen van legrassen, $<18$ wk & 30 & EFSvV: A & 2.50 & $=\mathrm{E} 2$ & 506 & $=\mathrm{E} 2$ & 218 & $=\mathrm{E} 2$ & 536 \\
\hline E2 & Legkippen en (groot-)ouderdieren van legrassen & 84 & EFSvV: G & 2.50 & {$[4]$} & 506 & G: [6] & 218 & G: [6] & 536 \\
\hline E3 & (Groot)ouderdieren van vleeskuikens in opfok & 23 & EFSvV: A & 2.50 & $=\mathrm{E} 2$ & 506 & $=\mathrm{E} 2$ & 218 & $=\mathrm{E} 2$ & 536 \\
\hline E4 & (Groot)ouderdieren van vleeskuikens & 43 & EFSvV: A & 2.50 & $=\mathrm{E} 2$ & 506 & $=\mathrm{E} 2$ & 218 & $=\mathrm{E} 2$ & 536 \\
\hline E5 & Vleeskuikens & 22 & EFSvV: G & 2.27 & {$[4]$} & 680 & G: [6] & 439 & G: [6] & 762 \\
\hline E6 & $\begin{array}{l}\text { Additionele technieken voor mestbewerking en } \\
\text { mestopslag }\end{array}$ & --- & --- & --- & --- & --- & --- & --- & --- & --- \\
\hline E7 & Additionele technieken voor emissiereductie van fijnstof & --- & --- & --- & --- & --- & --- & --- & --- & --- \\
\hline F1 & Ouderdieren van vleeskalkoenen in opfok; tot 6 weken & 23 & EFSvV: A & 2.27 & $=\mathrm{E} 5$ & 680 & $=\mathrm{E} 5$ & 439 & $=\mathrm{E} 5$ & 762 \\
\hline $\mathrm{F} 2$ & Ouderdieren van vleeskalkoenen in opfok; van 6 tot 30 wk & 163 & EFSvV: A & 2.27 & $=\mathrm{E} 5$ & 680 & $=\mathrm{E} 5$ & 439 & $=\mathrm{E} 5$ & 762 \\
\hline F3 & Ouderdieren van vleeskalkoenen van 30 weken en ouder & 207 & EFSvV: A & 2.50 & $=\mathrm{E} 2$ & 506 & $=\mathrm{E} 2$ & 218 & $=\mathrm{E} 2$ & 536 \\
\hline
\end{tabular}




\begin{tabular}{|c|c|c|c|c|c|c|c|c|c|c|}
\hline F4 & Vleeskalkoenen & 86 & EFSvV: G & 2.27 & $=\mathrm{E} 5$ & 680 & $=\mathrm{E} 5$ & 439 & $=\mathrm{E} 5$ & 762 \\
\hline G1 & Ouderdieren van vleeseenden tot 24 maanden & 182 & EFSvV: A & 2.50 & $=\mathrm{E} 2$ & 506 & $=\mathrm{E} 2$ & 218 & $=\mathrm{E} 2$ & 536 \\
\hline G2 & Vleeseenden & 84 & EFSvV: A & 2.27 & $=\mathrm{E} 5$ & 680 & $=\mathrm{E} 5$ & 439 & $=\mathrm{E} 5$ & 762 \\
\hline $\mathrm{H}$ & Pelsdieren/nertsen (per teef +5.5 pup +0.24 reu) & 8 & EFSvV: G & 2.50 & $=\mathrm{E} 2$ & 131 & L: [8] & 40 & L: [8] & --- \\
\hline 11 & Konijnen: voedster incl. 0.15 ram en jongen tot spenen & 5.4 & {$[2]$} & 2.50 & $=\mathrm{E} 2$ & 506 & $=\mathrm{E} 2$ & 218 & $=\mathrm{E} 2$ & --- \\
\hline 12 & Konijnen: vlees en opfokkonijnen tot dekleeftijd & 2.2 & {$[2]$} & 2.50 & $=\mathrm{E} 2$ & 506 & $=\mathrm{E} 2$ & 218 & $=\mathrm{E} 2$ & --- \\
\hline J1 & Parelhoenders voor de vleesproductie & 31 & EFSvV: A & 2.27 & $=\mathrm{E} 5$ & 680 & $=\mathrm{E} 5$ & 439 & $=\mathrm{E} 5$ & --- \\
\hline K1 & Volwassen paarden ( 3 jaar en ouder) & 148 & $=1,00 \times \mathrm{A} 1[3]$ & 16.67 & $=\mathrm{A} 1$ & 2900 & L: [9] & 957 & L: [9] & 2745 \\
\hline K2 & Paarden in opfok (jonger dan 3 jaar) & 74 & $=0,50 \times A 1[3]$ & 16.67 & $=\mathrm{A} 1$ & 2900 & [9] & 957 & [9] & 2745 \\
\hline K3 & Volwassen pony's ( 3 jaar en ouder) & 99 & $=0,66 \times A 1[3]$ & 16.67 & $=\mathrm{A} 1$ & 2900 & [9] & 957 & [9] & 2745 \\
\hline K4 & Pony's in opfok (jonger dan 3 jaar) & 49 & $=0,33 \times A 1[3]$ & 16.67 & $=\mathrm{A} 1$ & 2900 & [9] & 957 & [9] & 2745 \\
\hline
\end{tabular}

Verklaring afkortingen en informatiebronnen:

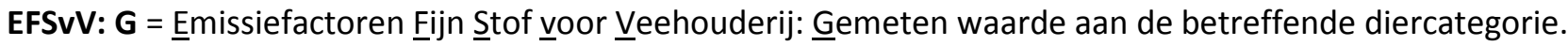

EFSVV: A = Emissiefactoren Fijn Stof voor Veehouderij: Afgeleide waarde van een andere diercategorie die wel is bemeten.

$\mathrm{G}:=$ endotoxine gehalte op basis van Gemeten waarde aan de betreffende diercategorie.

$\mathrm{L}:$ = endotoxine gehalte afgeleid op basis van Literatuur voor de betreffende diercategorie.

* = gefit endotoxine gehalte ( $\mathrm{EU}$ per $\mathrm{mg}$ ) in de $\mathrm{PM}_{100}$ fractie gebruikt in de modellering gefit op basis van de uit de gemeten of afgeleide endotoxine gehalten en de deeltjesgrootte verdeling (voor details zie tekst en tabel A.1.2 en A.1.3) 


\section{[1] Emissie $\mathbf{P M}_{10}$ geiten}

In twee rapporten zijn emissiemetingen beschreven die uitgevoerd zijn in twee geitenstallen. De gemiddelde $\mathrm{PM}_{10}$ emissie van deze geitenstallen bedroeg $47 \mathrm{~g} /$ dierplaats per jaar. Dit is meer dan een factor twee hoger dan de emissiefactor voor deze diercategorie: $19 \mathrm{~g} /$ dierplaats per jaar (categorie C 1, lijst Emissiefactoren Fijn Stof voor Veehouderij). In de basistabel met emissiedata is 47 g/dierplaats per jaar genomen als emissie voor geiten ouder dan 1 jaar. Geiten jonger dan 1 jaar (categorieën C 2 en C 3 ) hebben in voornoemde lijst een emissiefactor van $10 \mathrm{~g} /$ dierplaats per jaar. In de basistabel is de emissie van C 2 en C3 eveneens verhoogd waarbij de verhouding 10/19 $\mathrm{g} /$ dierplaats per jaar is gehandhaafd. De emissie van deze categorieën bedraagt daarmee $(10 / 19 \times 47$

=) $25 \mathrm{~g} /$ dierplaats per jaar.

\section{[2] Emissie $\mathbf{P M}_{10}$ Konijnen}

In een artikel worden $\mathrm{PM}_{10}$ emissies gerapporteerd van $14,9 \mathrm{mg} /$ dag per dierplaats voor voedsters en $5,99 \mathrm{mg} /$ dag per dierplaats voor vleeskonijnen. ${ }^{49}$ Deze waarden zijn equivalent aan respectievelijk $\left(14,9 \times 10^{-3} \times 365\right.$ dagen $\left.=\right) 5,4 \mathrm{~g} / \mathrm{jaar}$ per dierplaats en $\left(5,99 \times 10^{-3} \times 365\right.$ dagen $\left.=\right) 2,2 \mathrm{~g} / \mathrm{jaar}$ per dierplaats.

\section{[3] Emissie melkvee, runderen, paarden en pony's}

De $\mathrm{PM}_{10}$ emissies van $\mathrm{K} 1, \mathrm{~K} 2$, $\mathrm{K} 3$ en $\mathrm{K} 4$ zijn afgeleid van de $\mathrm{PM}_{10}$ emissie van melkkoeien (A1) op basis van het gemiddelde lichaamsgewicht van een melkkoe (circa $625 \mathrm{~kg}$ ) versus die van volwassen pony's (schofthoogte tot $147 \mathrm{~cm}$; circa $400 \mathrm{~kg}$ ) en volwassen paarden (schofthoogte 147-173 cm; 500-800 $\mathrm{kg})$. Naar rato van het lichaamsgewicht is de $\mathrm{PM}_{10}$ emissie geschat als $0,66 \times \mathrm{A} 1$ voor volwassen pony's en 1,00 × A1 voor volwassen paarden. De emissies van deze diercategorieën in opfok zijn ingeschat als de helft van de emissie van volwassen dieren.

\section{[4] $\mathrm{PM}_{10} / \mathrm{PM}_{100}$ ratio's voor melkvee, biggen, zeugen, vleesvarkens, leghennen, vleeskuikens} Zie pagina 211, linker kolom in het artikel door Winkel e.a. ${ }^{48}$ Hier worden $\mathrm{PM}_{10} / \mathrm{PM}_{100}$ ratio's gerapporteerd (op basis van $\mathrm{PM}_{10}$ en $\mathrm{PM}_{100}$ concentraties in stallucht, waarvan PM10 concentraties zijn gecorrigeerd voor achtergrondconcentraties) van: 0,06 voor melkvee, 0,31 voor biggen, 0,32 voor zeugen, 0,32 voor vleesvarkens, 0,40 voor leghennen en 0,44 voor vleeskuikens. De $\mathrm{PM}_{100} / \mathrm{PM}_{10}$ ratio's in Tabel A.1.3 zijn verkregen door omzetting via: 1 / [voornoemde ratio].

\section{[5] $\mathrm{PM}_{10} / \mathrm{PM}_{100}$ ratio geiten}

In twee onderzoeken van de WUR worden de resultaten van metingen gepresenteerd..$^{5051}$ De overall $\mathrm{PM}_{100}$ emissie bedroeg $137 \mathrm{~g} / \mathrm{j}$ aar per dierplaats. De overall $\mathrm{PM}_{10}$ emissie bedroeg 46,7 g/jaar per dierplaats. De $\mathrm{PM}_{100} / \mathrm{PM}_{10}$ ratio bedraagt daarmee $(137 / 46,7=)$ 2,93.

\section{[6] Endotoxine gehalten in monsters afkomstig uit verschillende diersectoren}

Deze endotoxinegehalten in stof zijn afkomstig uit het lopende onderzoeksprogramma "Ontwikkeling Toetsingskader Endotoxine-emissies". De getoonde endotoxinegehalten betreffen deels nog ongepubliceerde gegevens. Een eerste reeks gegevens is al wel gepubliceerd. ${ }^{8}$

\section{[7] Endotoxine gehalte fijnstof geiten}

Er zijn weinig studies die endotoxineconcentraties in de lucht en endotoxinegehalten in het stof van geitenstallen onderzocht hebben. In Nederland zijn endotoxinegehalten gemeten door Wageningen UR in studie en door het IRAS in een ZONMW-project naar het voorkomen van Coxiella burnettii in geitenbedrijven. ${ }^{51}{ }^{52}$ De endotoxineresultaten van het ZONMW project zijn niet apart gepubliceerd maar beschikbaar via het IRAS. In deze studie zijn in vijf melkgeitenbedrijven weekgemiddelde $\mathrm{PM}_{10}$ 
metingen verricht op 1.5 tot 3 meter hoogte in de stal met behulp van Harvard Impactors. De metingen zijn gestart enkele weken voor het lammerseizoen en liepen door tot drie à vier weken na het lammerseizoen. In twee van de vijf stallen zijn ook enkele $\mathrm{PM}_{100}$ metingen uitgevoerd. Het endotoxinegehalte voor geiten bedrijven is afgeleid door een gewogen gemiddelde te bepalen van gegevens uit beide studies, waarbij gewogen is naar het aantal bedrijven in de studie en het totale aantal metingen binnen de bedrijven.

De endotoxinebepalingen zijn niet gelijk voor de twee studies. De gemiddelde endotoxinegehalten in de eerste studie bedroegen $76 \mathrm{EU} / \mathrm{mg}$ voor $\mathrm{PM}_{100}$ en $211 \mathrm{EU} / \mathrm{mg}$ voor $\mathrm{PM}_{10}$. In deze studie werd de hoeveelheid endotoxine bepaald met een zogenaamd "eindpunt LAL-assay" terwijl in het lopende onderzoeksprogramma "Ontwikkeling Toetsingskader Endotoxine-emissies" en in de studie van Van Leuken e.a. een te prefereren "kinetische LAL-assay" is gebruikt, zoals voorgeschreven in het Europees protocol voor endotoxinemetingen in de werkomgeving (EN14031). Uit eerder onderzoek is bekend dat de uitkomsten van de kinetische versus eindpunt assays zich in een verhouding 1:0,214 tot elkaar verhouden. ${ }^{53}$ De in de WUR studie gerapporteerde endotoxinegehalten in het stof zijn daarom met een factor $(1 / 0,214=)$ 4,67 verhoogd. De bedrijfsgemiddelde endotoxinegehalten in de ZONMW-studie bedroegen $4290 \mathrm{EU} / \mathrm{mg}$ voor $\mathrm{PM}_{100}$ en $2600 \mathrm{EU} / \mathrm{mg}$ voor $\mathrm{PM}_{10}$. Het gewogen gemiddelde van beide studies bedraagt $3308 \mathrm{EU} / \mathrm{mg}$ in $\mathrm{PM}_{100}$ en $2504 \mathrm{EU} / \mathrm{mg}$ in $\mathrm{PM}_{10}$ (zie onderstaande tabel).

\begin{tabular}{|c|c|c|c|c|c|c|c|}
\hline \multirow[b]{2}{*}{ Studie } & \multirow[b]{2}{*}{ Bedrijf } & \multicolumn{3}{|c|}{$\begin{array}{l}\text { Endotoxine gehalte in } \\
\mathrm{PM}_{10}(\mathrm{EU} / \mathrm{mg})\end{array}$} & \multicolumn{3}{|c|}{$\begin{array}{l}\text { Endotoxine gehalte in } \\
\mathrm{PM}_{100}(\mathrm{EU} / \mathrm{mg})\end{array}$} \\
\hline & & $\mathrm{n}$ & AM & $(s d)$ & $\mathrm{n}$ & AM & (sd) \\
\hline \multirow[t]{6}{*}{ ZONMW De Rooij e.a. ${ }^{52}$} & 1 & 13 & 2129 & (549) & & & \\
\hline & 2 & 8 & 2960 & $(1450)$ & & & \\
\hline & 3 & 14 & 3438 & (1260) & 6 & 5673 & (1968) \\
\hline & 4 & 11 & 1929 & (646) & 6 & 2913 & (761) \\
\hline & 5 & 14 & 2545 & $(1192)$ & & & \\
\hline & Gem. & & 2600 & & & 4293 & \\
\hline WUR Aarnink e.a. ${ }^{5051}$ & $1 \& 2$ & 4 & $985^{*}$ & & 4 & $355^{*}$ & \\
\hline Gewogen gemiddelde & & & 2504 & & & 3308 & \\
\hline
\end{tabular}

\section{[8] Endotoxinegehalte fijnstof nertsen}

Het endotoxinegehalte van $131 \mathrm{EU} / \mathrm{mg}$ in $\mathrm{PM}_{100}$ in nertsenstallen is afkomstig van persoonlijke blootstellingsmetingen aan $\mathrm{PM}_{100}$ en de endotoxine concentratie in $\mathrm{PM}_{100}$, uitgevoerd in drie Deense nertsenbedrijven. ${ }^{54}$ De auteur van deze studie heeft de onderliggende gegevens beschikbaar gesteld, waardoor het mogelijk was voor de individuele metingen het endotoxinegehalte te bepalen. In deze studie zijn persoonlijke metingen uitgevoerd gedurende een periode van circa 6 uur. Het is bekend dat persoonlijke metingen in het algemeen resulteren in hogere concentraties dan stationaire metingen. Het is waarschijnlijk dat dit ten dele ook geldt voor het endotoxinegehalte in het stof, aangezien bij de persoonlijke metingen de bron zich meer nabij bevindt. Om hiervoor te corrigeren is een factor 1,5 aangehouden, afgeleid op basis van een studie waarin zowel persoonlijke als stationaire metingen in paardenstallen zijn uitgevoerd. ${ }^{55}$ Het endotoxinegehalte van $40 \mathrm{EU} / \mathrm{mg}$ in $\mathrm{PM}_{10}$ in nertsenstallen is afkomstig van een studie waarbij herhaald tweeweeks gemiddelde $\mathrm{PM}_{10}$ metingen zijn uitgevoerd met behulp van een Harvard impactor in één nertsenhouderij als onderdeel 
van het VGO project (Bijlage 7 van VGO aanvullende studies. PDF online beschikbaar op: http://www.rivm.nl/vgo/aanvullende_studies_2017.). ${ }^{4}$

\begin{tabular}{|c|c|c|c|c|c|c|c|}
\hline \multirow[b]{2}{*}{ Studie } & \multirow[b]{2}{*}{ Bedrijf } & \multicolumn{3}{|c|}{$\begin{array}{l}\text { Endotoxine gehalte in } \\
\mathrm{PM}_{10}(\mathrm{EU} / \mathrm{mg})\end{array}$} & \multicolumn{3}{|c|}{$\begin{array}{l}\text { Endotoxine gehalte } \\
\text { in } \mathrm{PM}_{100}(\mathrm{EU} / \mathrm{mg})\end{array}$} \\
\hline & & $\mathrm{n}$ & AM & $(\mathrm{sd})$ & $\mathrm{n}$ & AM & $(s d)$ \\
\hline \multicolumn{8}{|l|}{ Deense studie } \\
\hline \multirow[t]{3}{*}{ Basinas e.a. ${ }^{54}$} & 1 & & & & 1 & 533 & - \\
\hline & 2 & & & & 5 & 120 & (30) \\
\hline & 3 & & & & 1 & 240 & \\
\hline VGO deelstudie $^{4}$ & 1 & 9 & 40 & (28) & & & \\
\hline Studie gemiddelde & & & 40 & & & $131 *$ & \\
\hline
\end{tabular}

* het gewogen studie gemiddelde van het endotoxinegehalte in persoonlijke $\mathrm{PM}_{100}$ metingen bedraagt $196 \mathrm{EU} / \mathrm{mg}$; een correctiefactor van 1,5 is toegepast om het endotoxinegehalte in stationaire metingen te schatten, waarbij de eindschatting van het endotoxinegehalte in de $\mathrm{PM}_{100}$ fractie 196/1,5 = $131 \mathrm{EU} / \mathrm{mg}$ bedraagt.

\section{[9] Endotoxinegehalte fijnstof paarden}

Voor het schatten van het endotoxinegehalte in het stof van paardenstallen is gebruik gemaakt van gegevens van een studie in de paardenklinieken van de Universiteit Utrecht. ${ }^{56}$ In deze studie zijn stationaire $\mathrm{PM}_{100}$ metingen verricht gedurende een periode van 8 uur, zowel overdag als 's nachts. De metingen zijn uitgevoerd in stallen waarbij de paarden volgens een gereduceerd stofregime gehouden werden (stallen met houtkrullen en paarden kregen "haylage" gevoerd) en in stallen met meer gangbare omstandigheden (stallen met stro en paarden werden gevoed met hooi). Het endotoxinegehalte in $\mathrm{PM}_{100}$ bedroeg $1400 \mathrm{EU} / \mathrm{mg}$ (s.d. $600 \mathrm{EU} / \mathrm{mg}$ ) voor stallen met gereduceerd stof regime, en $2900 \mathrm{EU} / \mathrm{mg}$ (s.d. $1000 \mathrm{EU} / \mathrm{mg}$ ) voor stallen met gangbare omstandigheden. De waarden zoals waargenomen bij de gangbare omstandigheden zijn toegepast in de huidige studie.

Endotoxinegehalten in de $\mathrm{PM}_{10}$ fractie zijn niet bekend voor paardenstallen. Voor het schatten van het endotoxinegehalte in de $\mathrm{PM}_{10}$ fractie is de verhouding tussen de gehalten in $\mathrm{PM}_{10}$ en $\mathrm{PM}_{100}$ van Rav-categorie A1 Melkkoeien toegepast. Het endotoxinegehalte in de $\mathrm{PM}_{10}$ fractie voor paarden is daarmee geschat als $(260 / 788 \times 2900=) 957 \mathrm{EU} / \mathrm{mg}$. 
Tabel A1.2. Relatieve massabijdrage van de verschillende deeltjesfracties aan de $\mathrm{PM}_{100}$ massa naar diersoort

\begin{tabular}{|c|c|c|c|c|c|c|c|c|c|c|c|}
\hline \multirow[b]{2}{*}{ fractie no } & \multirow[b]{2}{*}{$\begin{array}{l}\text { deeltjesgrootte } \\
\text { in fractie }(\mu \mathrm{m})\end{array}$} & \multicolumn{10}{|c|}{ proportie massa in fractie van totale massa in $P M_{100}$} \\
\hline & & \begin{tabular}{|l|l}
$\begin{array}{l}\text { vlees- } \\
\text { kuikens }\end{array}$ \\
\end{tabular} & $\begin{array}{l}\text { leghennen } \\
\text { licht }\end{array}$ & $\begin{array}{l}\text { leghennen } \\
\text { donker }\end{array}$ & $\begin{array}{l}\text { leghennen } \\
\text { gemiddeld }\end{array}$ & \begin{tabular}{|l|} 
vlees- \\
varkens
\end{tabular} & zeugen & biggen & rundvee & geiten & paarden \\
\hline 1 & $1-6$ & 0.267 & 0.205 & 0.263 & 0.234 & 0.209 & 0.204 & 0.205 & 0.049 & 0.168 & 0.049 \\
\hline 2 & $6-10$ & 0.171 & 0.214 & 0.148 & 0.181 & 0.113 & 0.122 & 0.124 & 0.008 & 0.206 & 0.008 \\
\hline 3 & $10-16$ & 0.097 & 0.118 & 0.120 & 0.119 & 0.058 & 0.069 & 0.062 & 0.007 & 0.295 & 0.007 \\
\hline 4 & $16-22$ & 0.051 & 0.056 & 0.051 & 0.054 & 0.035 & 0.047 & 0.037 & 0.010 & 0.197 & 0.010 \\
\hline 5 & $22-28$ & 0.032 & 0.035 & 0.021 & 0.028 & 0.030 & 0.041 & 0.031 & 0.015 & 0.094 & 0.015 \\
\hline 6 & $28-35$ & 0.029 & 0.034 & 0.020 & 0.027 & 0.036 & 0.047 & 0.036 & 0.070 & 0.039 & 0.070 \\
\hline 7 & -45 & 0.039 & 0.048 & 0.044 & 0.046 & 0.060 & 0.070 & 0.060 & 0.129 & 0.014 & 0.129 \\
\hline 8 & $45-58$ & 0.060 & 0.067 & 0.092 & 0.080 & 0.095 & 0.098 & 0.094 & 0.168 & 0.007 & 0.168 \\
\hline 9 & $58-75$ & 0.097 & 0.094 & 0.135 & 0.114 & 0.146 & 0.133 & 0.147 & 0.220 & 0.003 & 0.220 \\
\hline 10 & $75-100$ & 0.160 & 0.132 & 0.106 & 0.119 & 0.215 & 0.186 & 0.236 & 0.324 & 0.001 & 0.324 \\
\hline
\end{tabular}

Tabel A.1.3. Endotoxinegehalte van stof voor de verschillende deeltjesfractie naar diersoort

\begin{tabular}{|c|c|c|c|c|c|c|c|c|c|c|c|}
\hline \multirow[b]{2}{*}{ fractie no } & \multirow[b]{2}{*}{$\begin{array}{c}\text { deeltjesgrootte in } \\
\text { fractie }(\mu \mathrm{m})\end{array}$} & \multicolumn{10}{|c|}{ endotoxine gehalte in fractie (EU/mg) } \\
\hline & & $\begin{array}{l}\text { vlees- } \\
\text { kuikens }\end{array}$ & $\begin{array}{l}\text { leghennen } \\
\text { licht }\end{array}$ & $\begin{array}{l}\text { leghennen } \\
\text { donker }\end{array}$ & $\begin{array}{l}\text { leghennen } \\
\text { gemiddeld }\end{array}$ & \begin{tabular}{|l} 
vlees- \\
varkens
\end{tabular} & zeugen & biggen & rundvee & geiten & paarden \\
\hline 1 & $1-6$ & 274 & 382 & 436 & 400 & 2620 & 1405 & 2383 & 630 & 2500 & 992 \\
\hline 2 & $6-10$ & 678 & 244 & 439 & 309 & 3544 & 1518 & 3422 & 630 & 2500 & 1224 \\
\hline 3 & $10-16$ & 1165 & 466 & 454 & 462 & 4540 & 1589 & 3839 & 582 & 2848 & 1355 \\
\hline 4 & $16-22$ & 1161 & 756 & 549 & 687 & 5322 & 1645 & 4086 & 466 & 3567 & 1522 \\
\hline 5 & $22-28$ & 1969 & 985 & 874 & 948 & 5500 & 1697 & 4269 & 334 & 4255 & 1694 \\
\hline 6 & $28-35$ & 2048 & 1145 & 1436 & 1242 & 5500 & 1761 & 4462 & 342 & 4860 & 1908 \\
\hline 7 & $35-45$ & 1550 & 1000 & 1573 & 1191 & 5300 & 1835 & 4590 & 500 & 4900 & 2155 \\
\hline 8 & $45-58$ & 1290 & 787 & 1578 & 1051 & 4884 & 1929 & 4715 & 708 & 4900 & 2467 \\
\hline 9 & $58-75$ & 884 & 600 & 1578 & 926 & 4235 & 2075 & 4910 & 965 & 4900 & 2954 \\
\hline 10 & $75-100$ & 363 & 600 & 1578 & 926 & 3400 & 2263 & 5160 & 1000 & 4900 & 3580 \\
\hline
\end{tabular}

Tabel A.1.4. Kentallen per diercategorie

\begin{tabular}{|c|c|c|c|c|c|c|c|c|}
\hline RAV-code & omschrijving & $\begin{array}{l}\text { PM10 } \\
\text { emissie }\end{array}$ & $\begin{array}{l}\text { stalhoogte } \\
(\mathrm{m})\end{array}$ & $\begin{array}{l}\text { emissie } \\
\text { hoogte } \\
(\mathrm{m})\end{array}$ & $\begin{array}{l}\text { emissie } \\
\text { snelheid } \\
\text { (Vs in } \mathrm{m} / \mathrm{s})\end{array}$ & a & b & $\begin{array}{l}\text { endotoxine } \\
\text { normconc } \\
\text { (EU/mg) }\end{array}$ \\
\hline A & rundvee & --- & 5 & 5,5 & 0,5 & 0,05 & 2 & 788 \\
\hline $\mathrm{C}$ & geiten & --- & 4 & 4,5 & 0,5 & 0,1 & 1,7 & 3308 \\
\hline $\bar{D} 1.1$ & biggen & --- & 6,5 & 6 & 4 & 0,2 & 1,7 & 4040 \\
\hline D3 & vleesvarkens traditioneel & $>150 \mathrm{~g} / \mathrm{dpl}$.jr & 6,5 & 6 & 4 & 0,2 & 1,8 & 4000 \\
\hline D3 & vleesvarkens lage emissie & $<150$ g/dpl.jr & 6,5 & 6 & 2,5 & 9 & 1,35 & 4000 \\
\hline Doverige & zeugen & --- & 6,5 & 6 & 4 & 0,2 & 1,7 & 1800 \\
\hline $\mathrm{E} 1, \mathrm{E} 2, \mathrm{E} 3, \mathrm{E} 4$ & leghennen lage emissie & $<40$ g/dpl.jr & 5 & 5,5 & 2,5 & 2 & 1,425 & 444 \\
\hline $\mathrm{E} 1, \mathrm{E} 2, \mathrm{E} 3, \mathrm{E} 4$ & leghennen traditioneel & $>40$ g/dpl.jr & 5 & 1,5 & 0,5 & 0,25 & 1,7 & 444 \\
\hline E5 & vleeskuikens traditioneel & $>20$ g/dpl.jr & 5 & 1,5 & 0,5 & 2 & 1,5 & 556 \\
\hline E5 & vleeskuikens lage emissie & $<20$ g/dpl.jr & 5 & 5,1 & 2,5 & 10 & 1,3 & 556 \\
\hline $\mathrm{F}$ & vleeskalkoenen & --- & 5 & 1,5 & 0,5 & 0,05 & 1,75 & 556 \\
\hline G & vleeseenden & --- & 5 & 1,5 & 0,5 & 0,05 & 1,75 & 444 \\
\hline $\mathrm{K}$ & paarden & --- & 5 & 5,5 & 0,5 & 0,05 & 2 & 2900 \\
\hline
\end{tabular}


Figuur A1.1. Fit van deeltjesgrootteverdeling en endotoxinegehaltes voor geiten en paarden
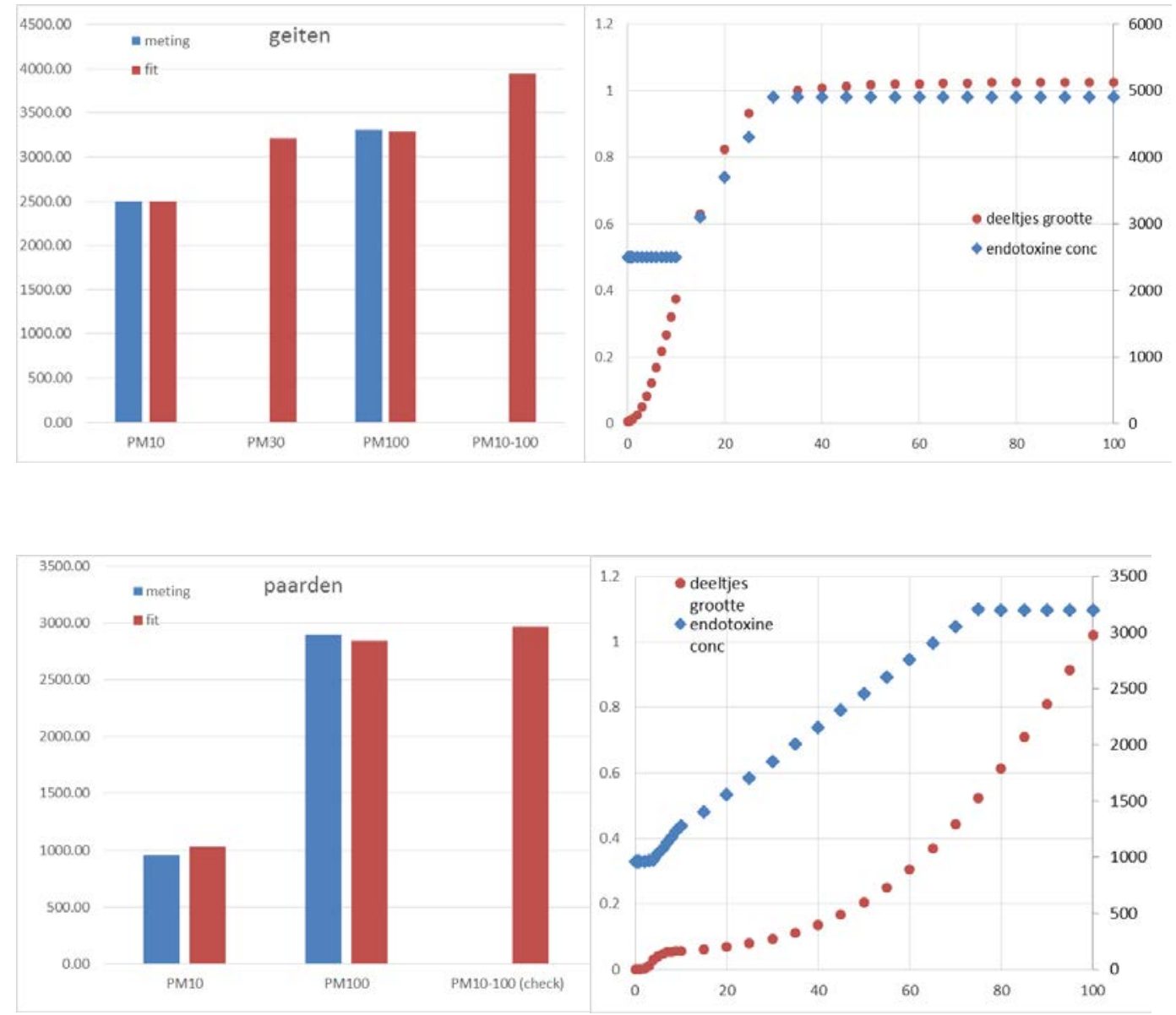


\section{Appendix 2a. Validatie RVG ten opzichte van VGO-}

\section{omgevingsmetingen}

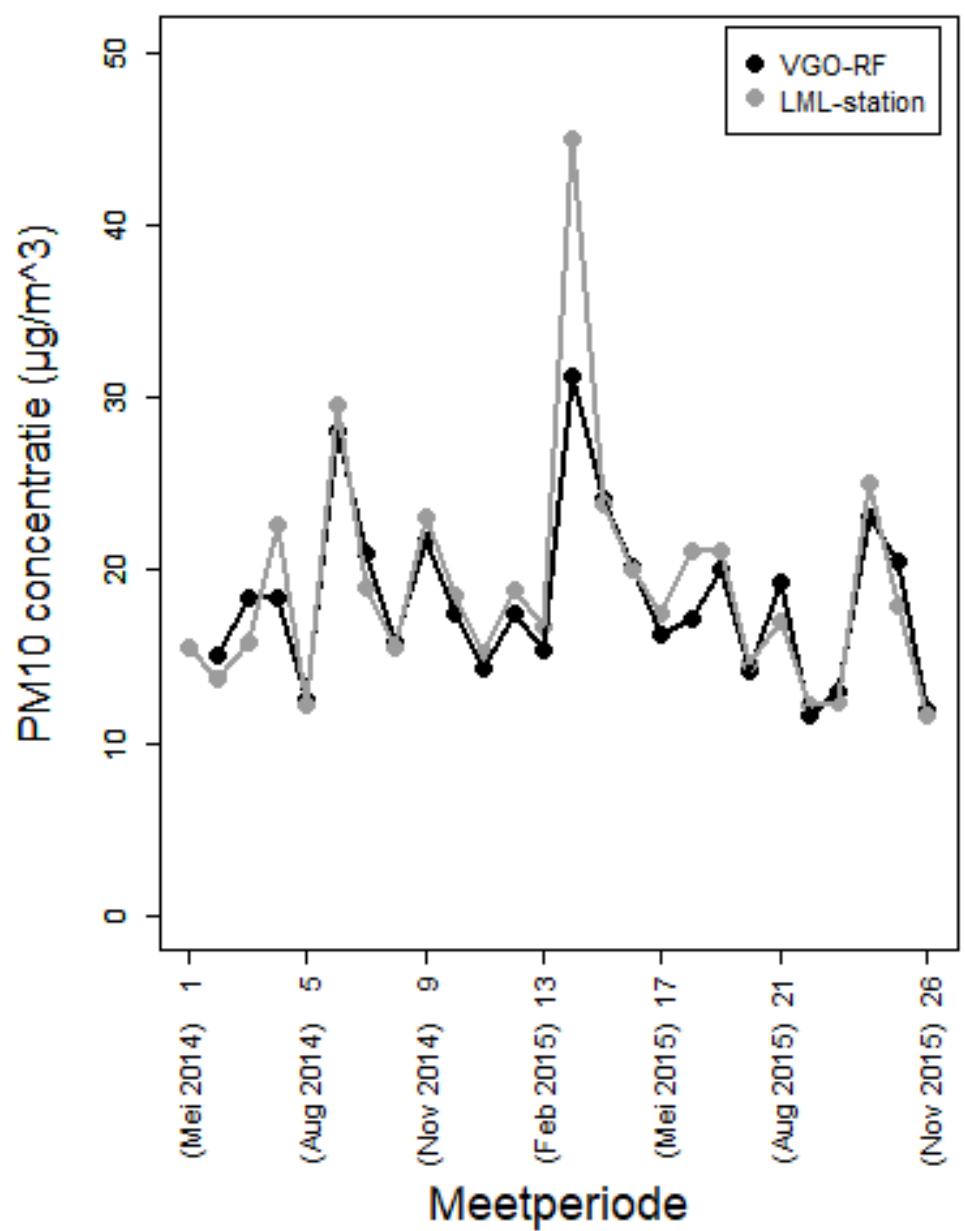

Figuur A2.1. Vergelijking gemeten $\mathrm{PM}_{10}$ concentraties op het VGO-referentiemeetpunt (VGO-RF) en het dichtstbij gelegen landelijk meetnetstation (LML-station). De correlatie is 0,92 op basis van een meetreeks van 25 metingen.

\section{Appendix 2b. Relatieve bijdrage diersectoren aan omgevingsendotoxineconcentraties}

In het algemeen is de relatieve mate van bijdrage van de hoofd diercategorieën vergelijkbaar voor de VGO-populatie ( $n=\sim 14.000$ ) en de grid punten van het $70 \times 70 \mathrm{~km}$ gebied $(n=\sim 310.00)$; zie figuur A2.2. De verdeling van de bijdrage van de hoofd diercategorieën illustreert dat in het algemeen verschillende diercategorieën in belangrijke mate bijdragen aan de endotoxine concentratie, de endotoxine concentratie wordt slechts sporadisch grotendeels (>80\%) bepaald door één hoofd diercategorie. De bijdrage van de varkenssector is het meest prominent aanwezig: de relatieve bijdrage bedraagt in meerderheid (tussen de 70 en $80 \%$ ) meer dan $40 \%$, en circa $40 \%$ is de relatieve bijdrage meer dan $60 \%$. Ook de bijdrage van de pluimveesector is aanzienlijk met circa $40 \%$ locaties met een relatieve bijdrage hoger dan 40\%. De bijdrage van de rundvee sector is in het algemeen 
minder prominent aanwezig. Opvallend is de verdeling over de sectoren anders is in het deel van de VGO-populatie waar het 99,5 percentiel voor de endotoxine concentratie hoger is dan $30 \mathrm{EU} / \mathrm{m}^{3}$, de rundvee sector en de varkenssector zijn hierin duidelijke bijdrages.

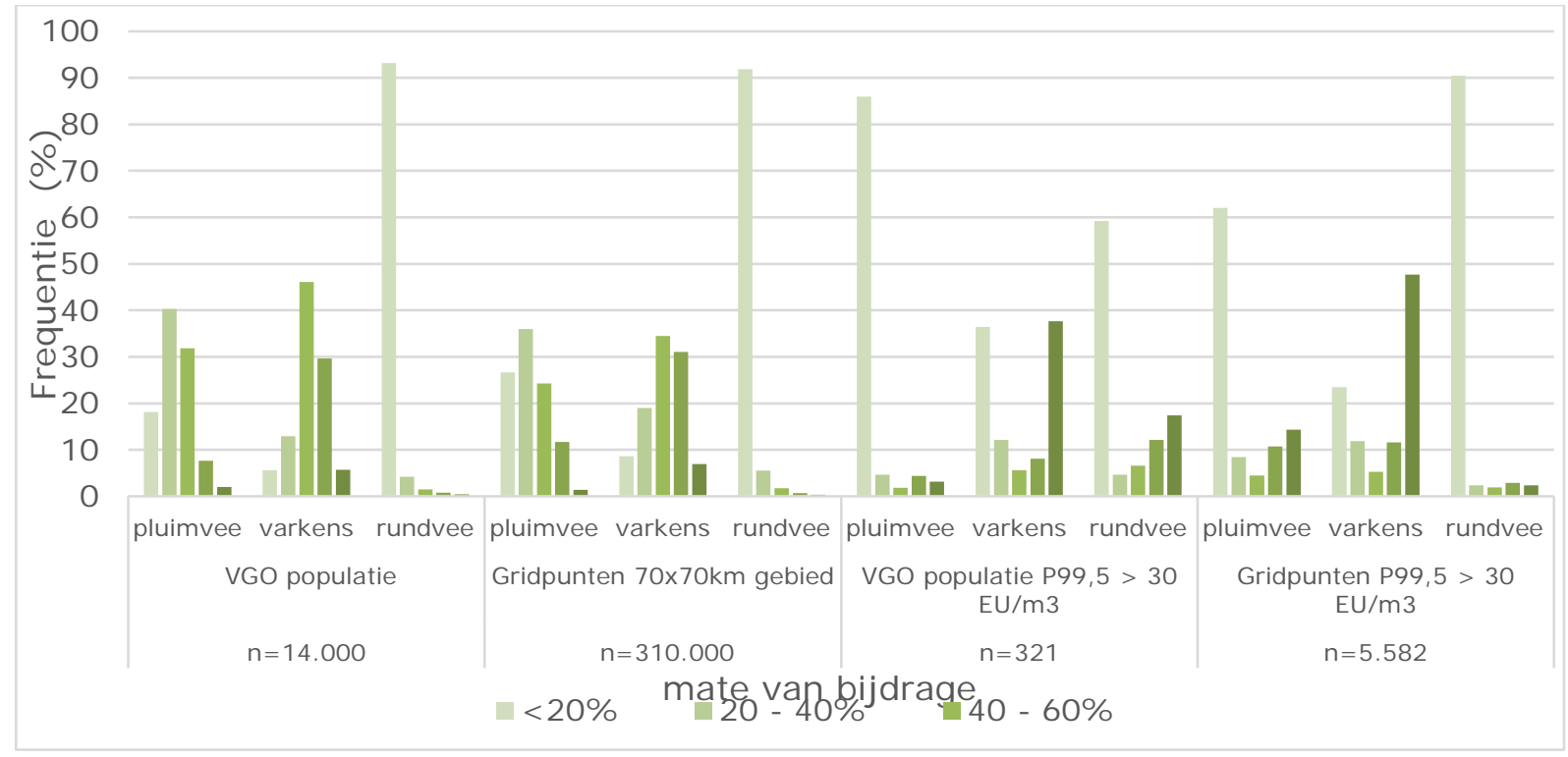

Figuur A2.2. Frequentieverdeling van de relatieve mate van bijdrage op de jaargemiddelde endotoxine concentraties van de hoofd diercategorieën pluimvee, varkens en rundvee binnen de onderzochte populaties/gebieden. 


\title{
Appendix 3. Artikel respiratoire effecten lage endotoxine concentraties
}

\section{Respiratory health effects of exposure to low levels of airborne endotoxin - a systematic review}

Azadèh Farokhi, Dick Heederik and Lidwien A. M. Smit (D)

\begin{abstract}
Background: Elevated endotoxin levels have been measured in ambient air around livestock farms, which is a cause of concern for neighbouring residents. There is clear evidence that occupational exposure to high concentrations of airborne endotoxin causes respiratory inflammation, respiratory symptoms and lung function decline. However, health effects of exposure to low levels of endotoxin are less well described. The aim of this systematic review is to summarize published associations between exposure to relatively low levels of airborne endotoxin and respiratory health endpoints. Methods: Studies investigating respiratory effects of measured or modelled exposure to low levels of airborne endotoxin (average $<100 \mathrm{EU} / \mathrm{m}^{3}$ ) were eligible for inclusion. In total, 1362 articles were identified through a Pubmed database search, of which 31 articles were included in this review. Studies were included up to February 2017. Overview tables and forest plots were created, and study quality was assessed.

Results: Twenty-two included studies had a cross-sectional design, others were designed as longitudinal observational $(n=7)$ or experimental $(n=2)$ studies. Most studies $(n=23)$ were conducted in an occupational setting, some involved domestic or experimental exposure. Several studies reported statistically significant effects of exposure to low levels of endotoxin on respiratory symptoms and lung function. However, considerable heterogeneity existed in the outcomes of the included studies and no overall estimate could be provided by meta-analysis to quantify the possible relationship. Instead, a best evidence synthesis was performed among studies examining the exposure-response relationship between endotoxin and respiratory outcomes. Significant exposure-response relationships between endotoxin and symptoms and $\mathrm{FEV}_{1}$ were shown in several studies, with no conflicting findings in the studies included in the best evidence synthesis. Significantly different effects of endotoxin exposure were also seen in vulnerable subgroups (atopics and patients with broncho-obstructive disease) and smokers.

Conclusions: Respiratory health effects of exposure to low levels of airborne endotoxin $\left(<100 \mathrm{EU} / \mathrm{m}^{3}\right)$ seem plausible. Future studies are needed to investigate ambient exposure to endotoxin and potential respiratory health effects, especially in vulnerable subgroups of the population.

Keywords: Endotoxin, Exposure, Lung function, Respiratory health, Environment
\end{abstract}

*Correspondence: L.ASmit@uu.nl

Institute for Risk Assessment Sciences (IRAS), Utrecht University, P.O. Box 80.178, 3508TD Utrecht, The Netherlands 


\section{Background}

Health effects of air pollution have mainly been studied in urban areas, where pollutant concentrations can be high due to emissions from industries and traffic. However, poor air quality in rural areas may also be of influence on people's health. In the Netherlands, regions where air quality is influenced by emissions from livestock farms are densely populated $[1,2]$. Since potential health effects of these emissions are relevant to all people living and working in these areas, the relationship between exposure and health is a current topic of research

Over the last thirty years, a considerable amount of research has been performed to gain insight into the respiratory health risks of people occupationally exposed to high concentrations of organic dust and endotoxin [3-6]. Inhalation of endotoxin, a lipopolysaccharide component of the cell-wall of Gram-negative bacteria present in organic dust, induces an inflammatory response in the lungs [6-9]. Aerosolized endotoxin is absorbed onto the surface of particulate matter and thus transported through the air $[7,10]$. By binding to the CD14/TLR4/MD2 receptor complex on macrophages it triggers the production of cytokines and proteins that cause inflammation $[8,9,11]$. When challenged with aerosolized endotoxin, people have shown a hundredfold increase in neutrophil levels and tripling of lymphocyte levels in bronchoalveolar fluid [12]. In 1987, Castellan et al. found a clear exposure-response relationship between endotoxin concentration and group mean percentage change in forced expiratory volume in one second $\left(\mathrm{FEV}_{1}\right)$ in individuals experimentally exposed to endotoxin containing cotton dust [13]. The effects of exposure to endotoxin are predominantly respiratory, including decline in lung function and increased prevalence of chronic bronchitis and asthma-like syndrome $[5,14,15]$. In addition to adverse health effects, occupational endotoxin exposure in agricultural workers has also been implicated in protective effects on allergic sensitisation and hay fever [16, 17].

While respiratory health effects of exposure to high levels of endotoxin are well described, potential effects associated with low levels of exposure are less well established. However, interest in the possible adverse health effects of endotoxin exposure on non-occupationally exposed populations is growing $[2,18]$. Ambient endotoxin concentrations in the proximity of livestock farms and bioaerosol levels near composting sites have been found to be in the lower range of exposure levels measured in several occupations $[19,20]$. Since it is not clear whether effects observed at high exposure levels can be extrapolated to lower exposure levels, further research is warranted. These outcomes are interesting for governmental institutions in particular, in order to formulate guidelines to protect the public health and safety of their inhabitants. Currently, the Dutch Expert Committee on Occupational Safety (DECOS) of the Health Council recommends a health-based occupational exposure limit of $90 \mathrm{EU} / \mathrm{m}^{3}$ [21]. DECOS regards an exposure level of $90 \mathrm{EU} / \mathrm{m}^{3}$ as a NOEL (no observed effect level), based on the effects on $\mathrm{FEV}_{1}$ of six-hour exposure to endotoxins in the study by Castellan et al. [13]. Based on the occupational exposure limit, a tentative limit of $30 \mathrm{EU} / \mathrm{m}^{3}$ was recommended for the general population living in the surroundings of livestock farms [21, 22].

The aim of this systematic review is to investigate the possible respiratory health effects of exposure to low levels of airborne endotoxin in humans. Levels up to 100 $\mathrm{EU} / \mathrm{m}^{3}$ are included since these levels can be compared to peak ambient levels of airborne endotoxin in livestockdense areas $[23,24]$ We hypothesize that exposure to these concentrations of endotoxin can have modest, but negative effects on respiratory health.

\section{Methods and design}

Design

This systematic review was performed by the first author (A.F.) in collaboration with the last author (L.A.M.S) and was performed according to the steps of the PRISMA statement [25].

\section{Information sources and search strategy}

The Pubmed database was searched for relevant literature published until February 14th 2017. Search terms used to find eligible articles were based on the terms endotoxin, exposure, lung function and respiratory symptoms (such as cough, wheeze, chest tightness and shortness of breath). The full electronic search query is presented in Additional file 1: Supplement 1. Reference lists of all included studies and relevant literature reviews were searched for additional eligible articles.

\section{Inclusion criteria}

Studies were eligible for inclusion if measurements of airborne endotoxin concentrations were performed, through either active or passive air sampling methods. Studies which used modelling approaches based on air exposure measurements were also included. Respiratory outcomes (lung function measurement and/or respiratory symptoms) had to be defined and described. Only human experimental or observational studies were included, with full text written in English, Dutch, German or French and which were originally published in peerreviewed journals. Case reports, literature reviews and non-human studies were excluded. Also studies with measurements of airborne endotoxin of only high levels of exposure (an average of $>100 \mathrm{EU} / \mathrm{m}^{3}$ ) were excluded, as were studies where endotoxin was measured in dust 
reservoirs only. The exposure variable of interest was exposure to low levels of endotoxin (average $<100 \mathrm{EU} / \mathrm{m}^{3}$ ). The main outcome was the effect on respiratory health; both on pulmonary function and occurrence of respiratory symptoms (coughing, wheezing, shortness of breath, asthma, dyspnoea).

\section{Study selection}

Assessment of manuscripts for meeting the inclusion criteria was performed in a Mendeley database. Duplicates were removed and subsequently studies were selected based on title or abstract for full text-screening. In case a study was excluded based on full text screening, the reason for exclusion was listed. In case several publications reported measurements from the same series, the one with the most detailed methodology description and original values was included.

\section{Data extraction}

Extraction of data was performed systematically by summarizing information on author, publication year, country, study design, endotoxin measurement techniques, spirometry measurements, questionnaires and confounders in overview tables.

Studies were categorized according to characteristics of the sample population (i.e., occupationally exposed subjects, respiratory disease patient groups or general population). Results are presented by individual study, since the studies were too heterogeneous in terms of endpoint measurement and presentation of endotoxin exposure levels, population samples, settings, reported outcomes and data analysis techniques to compare the results. Therefore, a narrative synthesis was performed and a best evidence synthesis was conducted for suitable outcome variables (see data synthesis). Also, forest plots were constructed (using $R$, version 3.3.2) to improve readability and comparability of the results.

\section{Methodological quality and risk of bias}

Assessing quality of evidence and risk of bias in individual studies was performed using the NIH Quality Assessment Tool for Observational Cohort and CrossSectional Studies [26]. This tool was designed to assess the methodological quality of cohort and cross-sectional studies. In this method, the quality of the studies is evaluated by rating fourteen items representing research question, study population and sample size, participation rate, timeframe, variation in exposure level, validity and reliability of exposure and outcome variables, blinding, loss to follow-up and confounding. Each item can be scored as 'yes', 'no, 'not applicable', 'cannot determine' or 'not reported'. The overall scores of the different studies were presented as percentages to improve comparability. Studies with total scores $\geq 90 \%$ were considered strong, studies scoring 70-90\% were considered of moderate quality and studies scoring below 70\% were considered weak.

\section{Data synthesis}

Because of the heterogeneity of the included studies we refrained from performing a meta-analysis, but conducted a best evidence synthesis to come to some overall conclusions using the method described by Proper [27]. Only those articles that investigated the exposureresponse relationship between endotoxin exposure and an outcome variable were included in the best evidence synthesis. Four outcome variables were selected for inclusion in the best evidence synthesis: wheeze, cough, (nocturnal) asthma symptoms and $\mathrm{FEV}_{1}$. Other reviews that applied this best evidence synthesis method considered results to be consistent when at least $75 \%$ of the studies showed statistically significant results in the same direction (defined according to $p<0.05$ ) [27-29]. Originally three possible levels of evidence followed from this best evidence synthesis method, namely strong, moderate and insufficient evidence. In our evidence synthesis, we added the category 'weak evidence' in case the results could not be considered consistent according to Proper (not meeting the criterion of at least $75 \%$ significant results), but all studies showed results in one direction, of which at least two studies with significant results, and no conflicting findings existed for an outcome variable.

\section{Results}

\section{Study selection}

The search yielded a total of 1362 articles. In Fig. 1, a PRISMA flowchart of the study selection is presented. After removal of duplicates $(n=3)$ and selection on language $(n=40), 1319$ articles remained. In total, 1153 articles were excluded based on title and abstract, leaving 166 articles to be assessed by screening the full text. Most of these articles were excluded because levels of exposure $(n=82)$, endotoxin level measurement techniques $(n=18)$ or study design $(n=28)$ did not match the inclusion criteria. Two studies were removed due to duplicate publication of the same endotoxin and outcome data $[30,31]$. Reference lists of all included studies and 11 relevant literature reviews were searched for additional eligible articles, but did not yield additional studies for inclusion. In total, 31 articles were included in this systematic review.

\section{Characteristics of included studies Setting and population}

An overview of the characteristics of the included studies is presented by publication date in Tables 1 and 2 . Of the studies that were included most had a cross-sectional design, seven studies were set up longitudinally (with follow 


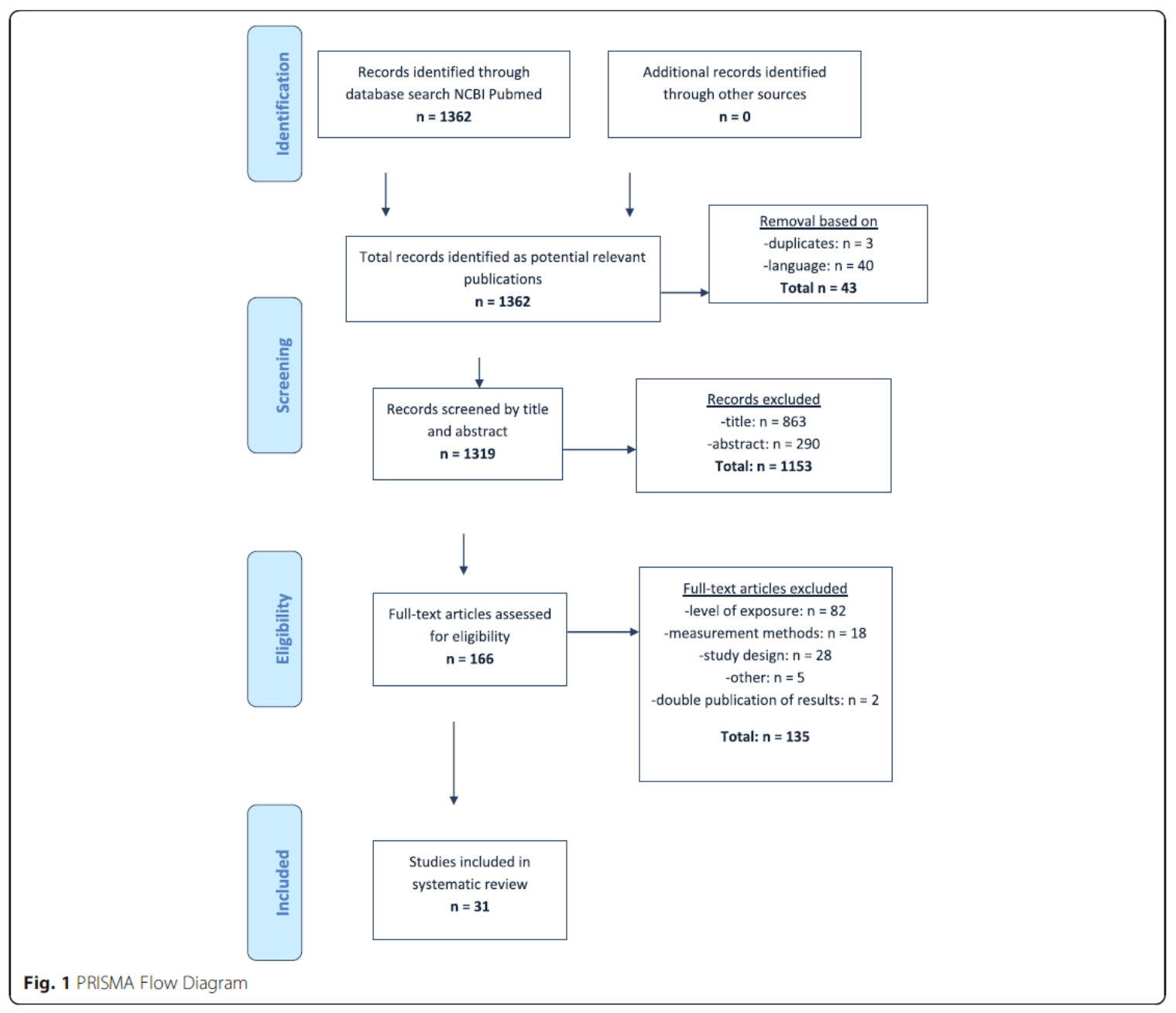

up periods between 5 days [32] and 11 years [33]) and two experimental studies $[34,35]$ were included. Eleven studies were performed in the United States, four in the Netherlands, three in Norway, two in Denmark, two in Switzerland, two in Sweden and one each in Australia, New Zealand, Germany, Canada, Pakistan, Poland and the UK. The included studies were performed between 1987 and 2016. Most of the studies examined endotoxin exposure among occupationally exposed subjects $(n=23)$, such as workers in wood, sewage and textile industries. Four studies focussed on susceptible populations, mostly children with asthma or adults with COPD. The remaining studies included children as a target population, except for one of the experimental studies where healthy adults were studied [35]. The number of included subjects ranged from 22 [36] to 3867 [37] subjects. In some cases the study was initiated because of specific reasons, such as a sudden increase in incidence of specific complaints reported by a group of workers. In some of these studies, other air pollutants than endotoxin were measured as well. We summarized important relationships between the other airborne agents and respiratory outcomes in Additional file 1: Supplement 2.

\section{Measured pollutants}

Dust was mostly collected with personal sampling techniques during working hours, alternatives used were area sampling and predictive calculations based on dispersion models [37, 38]. Endotoxin was measured using the Limulus Amebocyte Lysate (LAL) assay, which is the most accepted assay for endotoxin exposure measurements. The exposure agents measured in the included studies vary greatly. Some studies only reported measurement of the exposure to airborne endotoxin [39-44] whereas other studies included measurement of dust, bacteria, fungi and/or other airborne particles. 


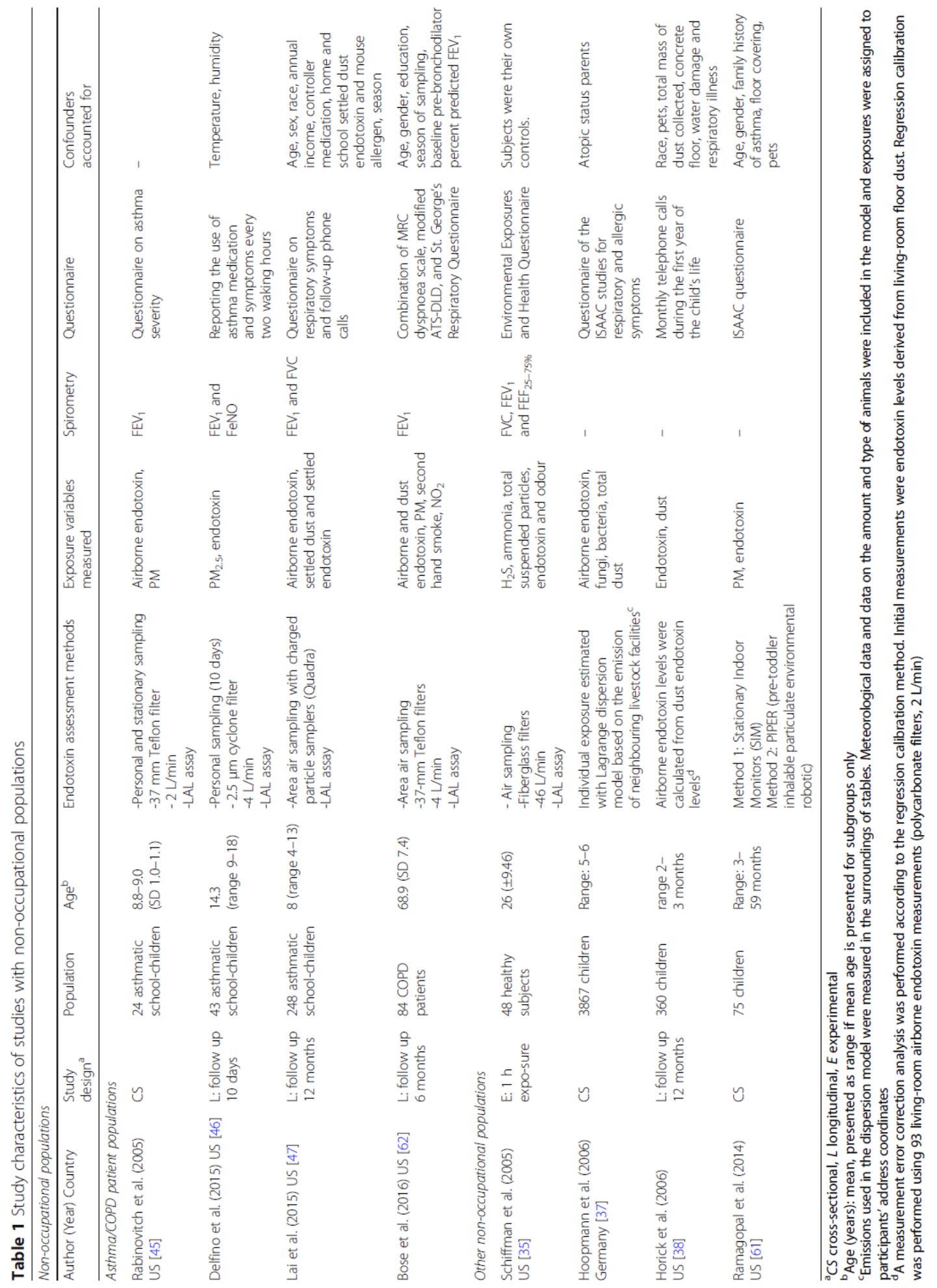




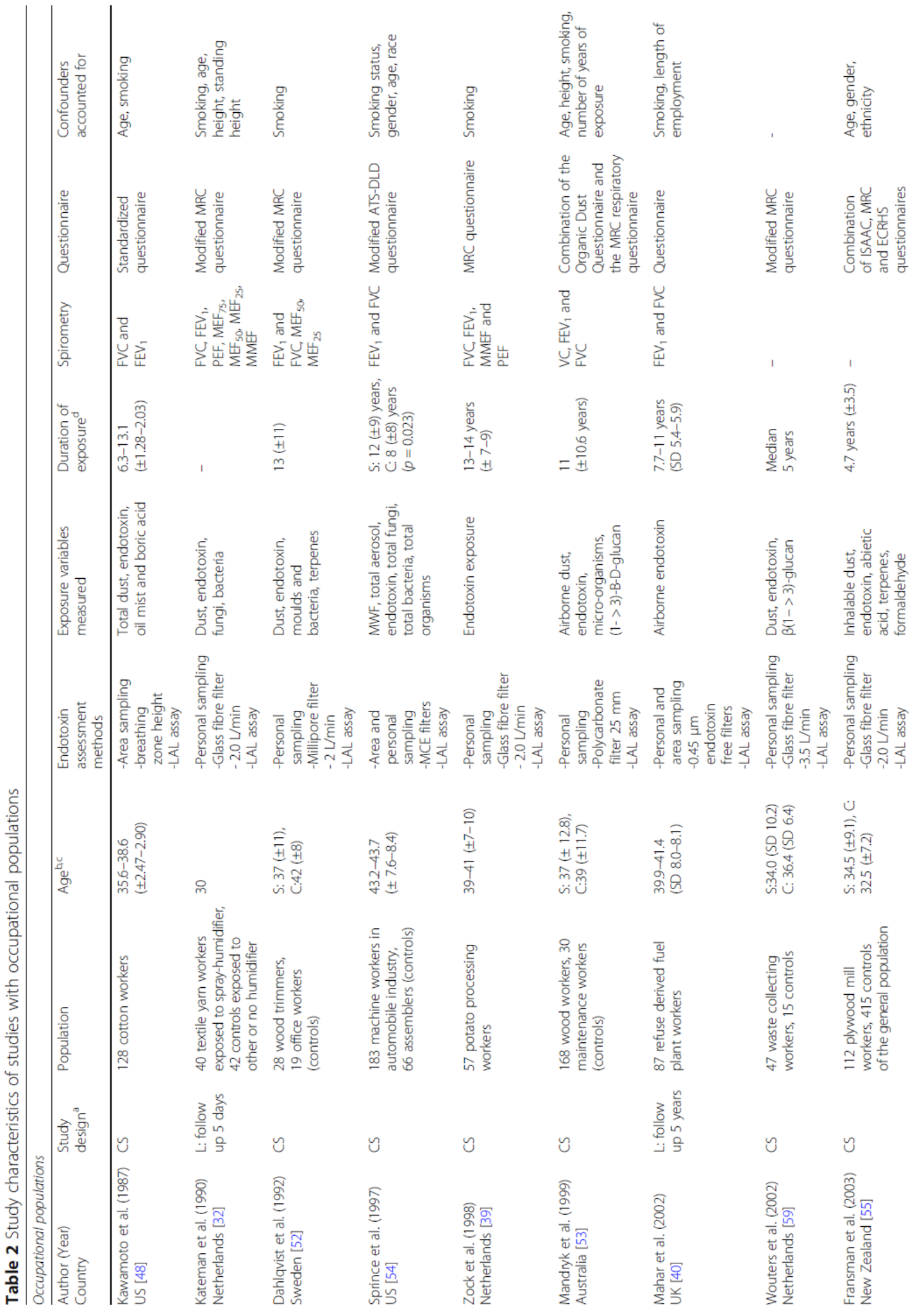




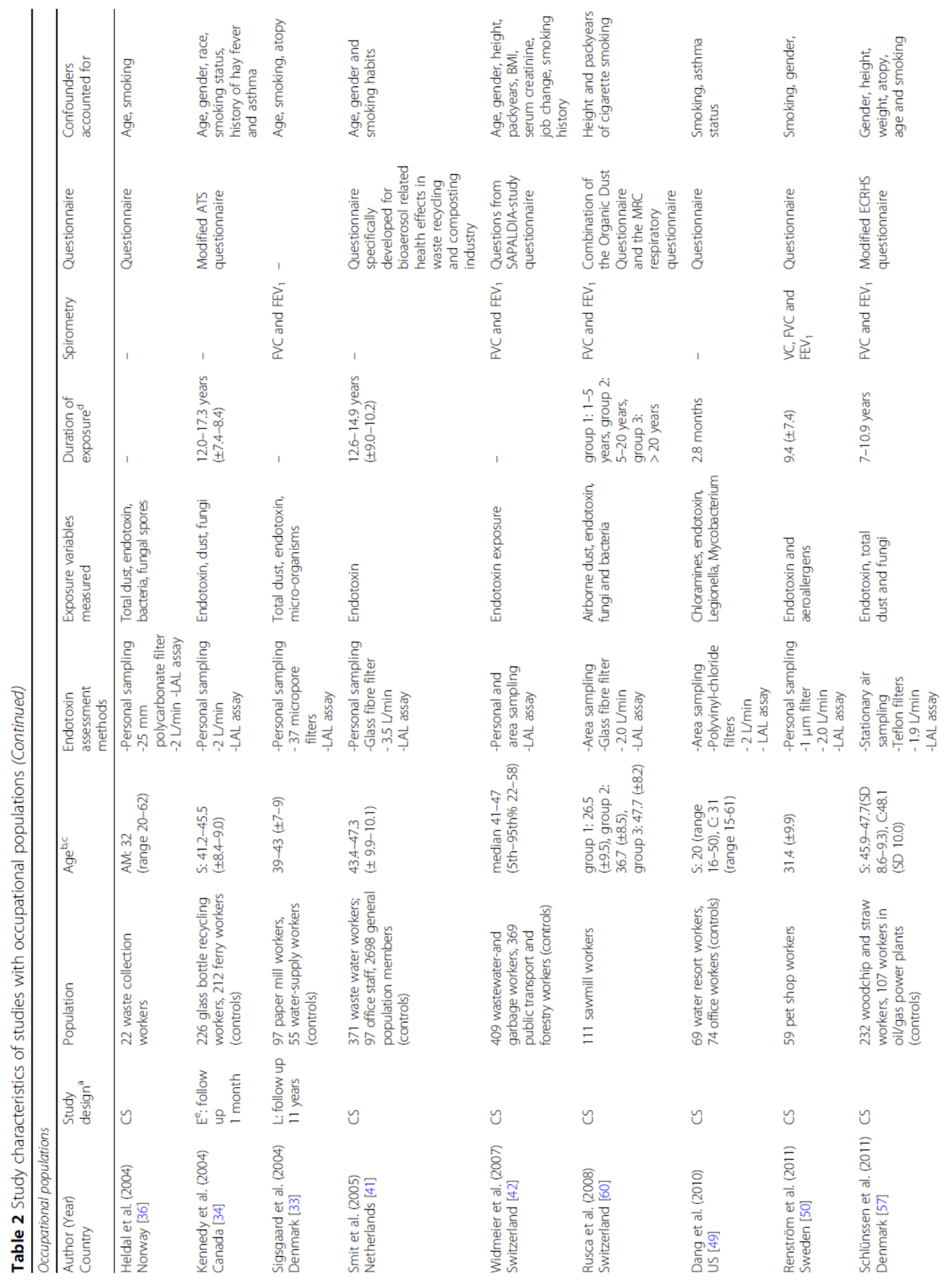




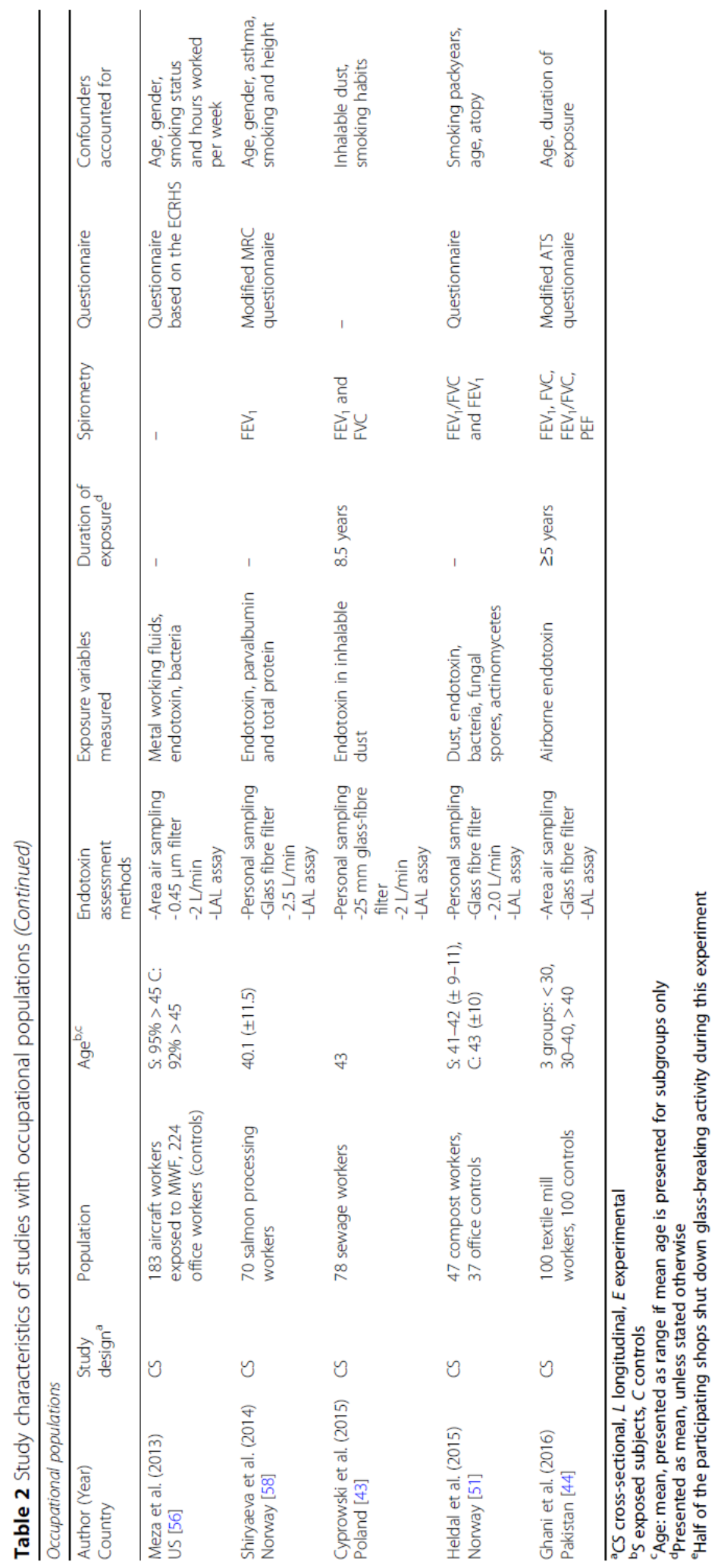




\section{Health outcomes}

Twenty-one studies performed spirometry measurements and included lung function values in their design, most of them included $\mathrm{FEV}_{1}$ and FVC as outcome measurements. All but three studies recorded symptoms through a questionnaire. Questionnaires used were often based on questions from the MRC, ATS, ECRHS or ISAAC questionnaires and the Organic Dust Questionnaire, but a number of other questionnaires were used as well as a source for the reporting of symptoms [35, 36, $40-42,45-51]$. The study by Horick et al. used monthly telephone calls to register respiratory symptoms [38].

\section{Quality assessment}

An overview of the quality assessment results is presented in Additional file 1: Supplement S3. All studies had welldescribed study objectives and most included detailed information on the study subjects. The main reason for scoring negative on study population description was the absence of the inclusion period. Eleven studies did not report the participation rate. All but one studies reported effect sizes, only Heldal et al. presented results otherwise [36]. Since most of the studies had a cross-sectional design, exposures were not measured prior to the outcomes. In case studies included cross-work shift or cross-week measurements of lung function values and in case of longitudinal studies, the item timeframe was scored positive. Twenty studies investigated effects of different levels of exposure. All studies used valid and reliable area or personal exposure measurements. Exposure assessment over time was scored positive when repeated personal full-work shift measurements were performed, area measurements were considered insufficient. Two studies used modelling to estimate personal endotoxin exposure, this was also regarded an accurate and reliable way of estimating exposure [37, 38]. Regarding outcome measures, spirometry measurements were considered valid and reliable, as was the use of validated questionnaires. Dang et al. were the only ones using an unvalidated questionnaire without performing additional spirometry measurements [49]. Blinding of outcome assessors was only applicable in non-occupational studies, as is reflected in the scoring of this criterion. Four studies did not perform/report correction for confounding. Since not all scoring items were applicable for all included studies, a percentage of the maximum score was calculated for each included study. The percentages of total scores varied between 55\% and $100 \%$. Most studies were considered moderate based on their score $(n=13)$, others were considered strong $(n=9)$ or weak $(n=9)$.

\section{Findings}

Main results of questionnaires, spirometry and doseresponse relationships are combined and summarised in Table 3.

\section{Questionnaire}

Respiratory symptoms recorded by most studies in cluded cough, wheezing, shortness of breath, chest tightness and nocturnal asthma symptoms. As presented in Additional file 1: Supplement S4.1, ten studies reported a significantly higher prevalence of respiratory symptoms among exposed subjects when compared to unexposed or lower exposed controls. The definition of exposure differed between studies, ranging from only endotoxin exposure (measured) to exposure to various bioaerosols The symptoms that were found to be significantly more prevalent among exposed subjects were cough [41, 49, 51-54], wheeze $[49,55,56]$, shortness of breath [41, 49, 52, 55], (work-related) chest tightness [34, 49, 54, 56], chronic bronchitis [53] and (work-related) asthmatic symptoms [41, 56, 57]. Fransman et al. found that plywood workers exposed to $23 \mathrm{EU} / \mathrm{m}^{3}$ endotoxin had significantly more attacks of shortness of breath with wheezing than unexposed controls and that workers employed > 6.5 years had significantly more asthma, shortness of breath and wheezing when compared to members of the general population [55]. Smit et al. also showed a significant positive association between length of employment and lower respiratory tract (LRT) symptoms [41]. Two studies found that respiratory symptoms lessened during holidays/days off; $53-83 \%$ of respiratory symptoms lessened during holidays in one study [55], another study found a PR of 2.84 (95\%CI 1.56-5.18) for decline in symptoms of wheeze during holidays [56]. Shiryaeva et al. found that the highest frequency of symptoms was present on Mondays and that symptoms decreased gradually over the week, wheeze and chest tightness decreased significantly [58].

One study among textile yarn workers exposed to different kinds of humidifiers (endotoxin levels 0.18-0.64 $\mathrm{EU} / \mathrm{m}^{3}$ ) did not find a significant difference in the reporting of symptoms among subpopulations [32]. Three other studies did not find a significant difference in prevalence of respiratory symptoms among exposed subjects when compared to controls [42, 59, 60]. Two studies did not find any difference in exposure levels of endotoxin between subjects with and without respiratory complaints $[36,50]$. In the study by Zock et al. among potato processing workers, subjects exposed to $21 \mathrm{EU} /$ $\mathrm{m}^{3}$ (AM) seemed to have more symptoms of respiratory symptoms than the group exposed to $56 \mathrm{EU} / \mathrm{m}^{3}$ (AM) [39]. Exposure to $7.40 \mathrm{EU} / \mathrm{m}^{3}$ for $1 \mathrm{~h}$ in an experimental setting did not significantly influence the prevalence of cough symptoms [35].

The forest plots in Fig. 2 show a summary of the effects of exposure (to endotoxin and other bioaerosols) on respiratory symptoms presented in the included studies. The odds ratios (or exp.(beta) for symptom score) of asthma, chest tightness, cough and wheeze appear to be 


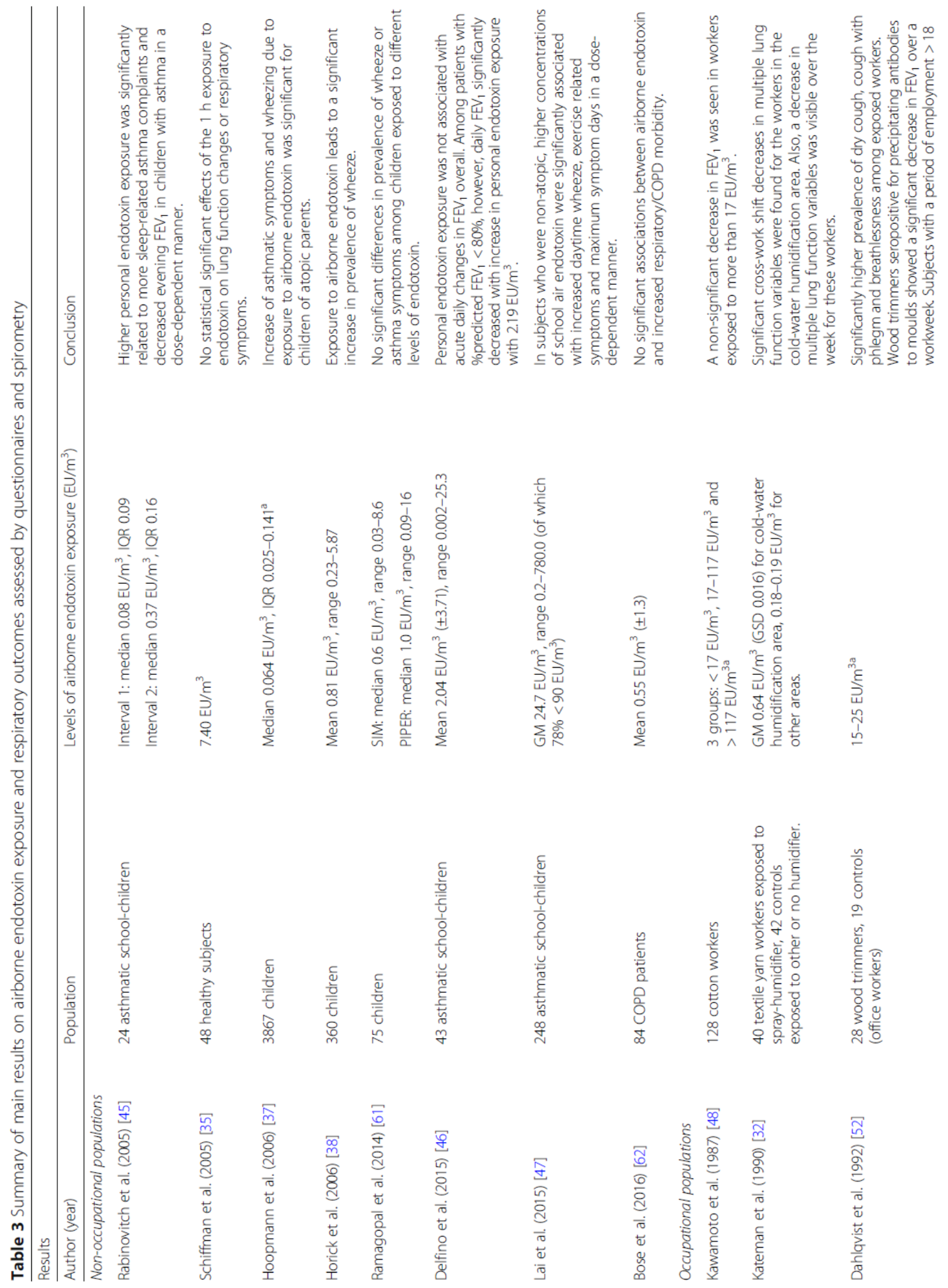




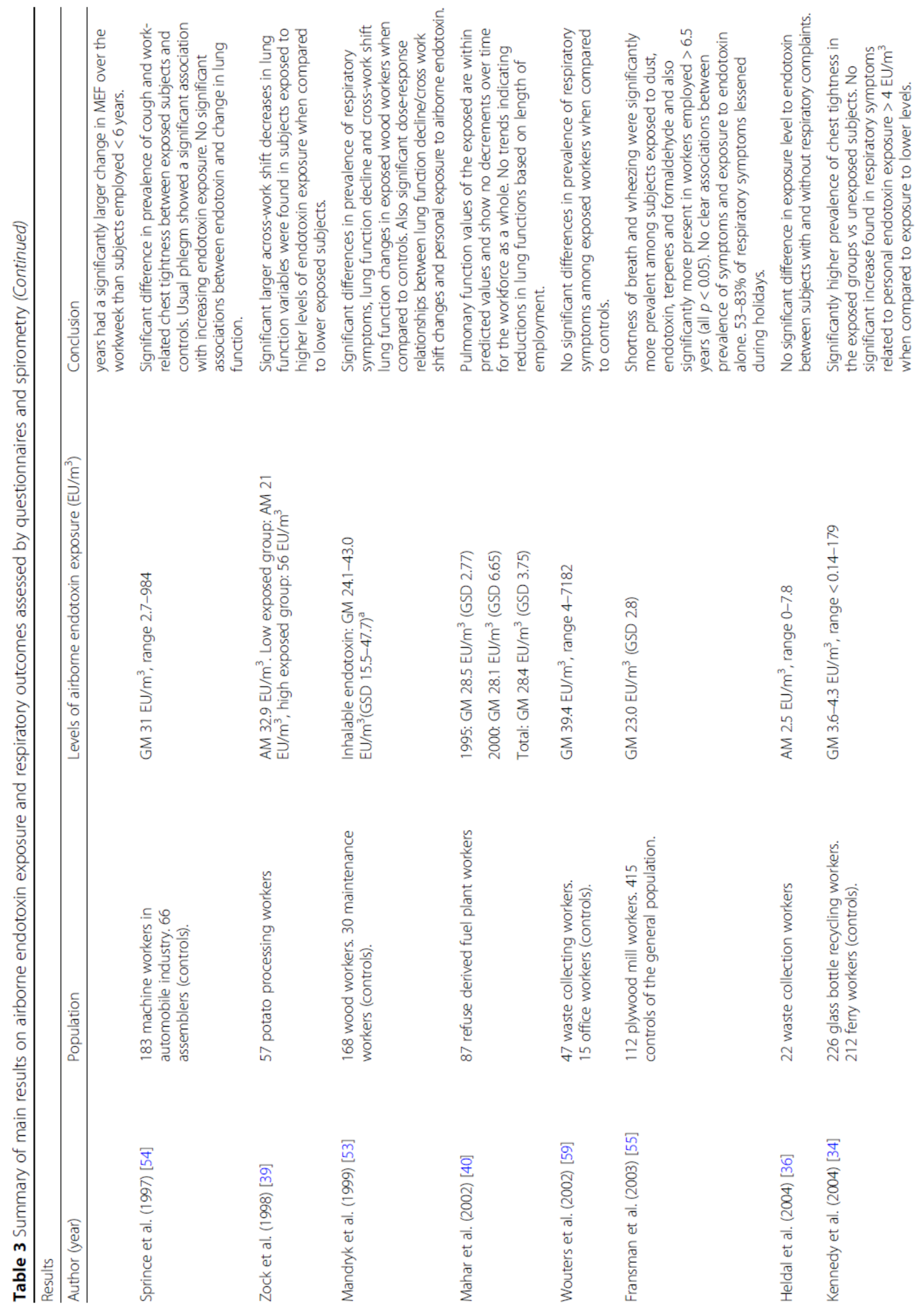




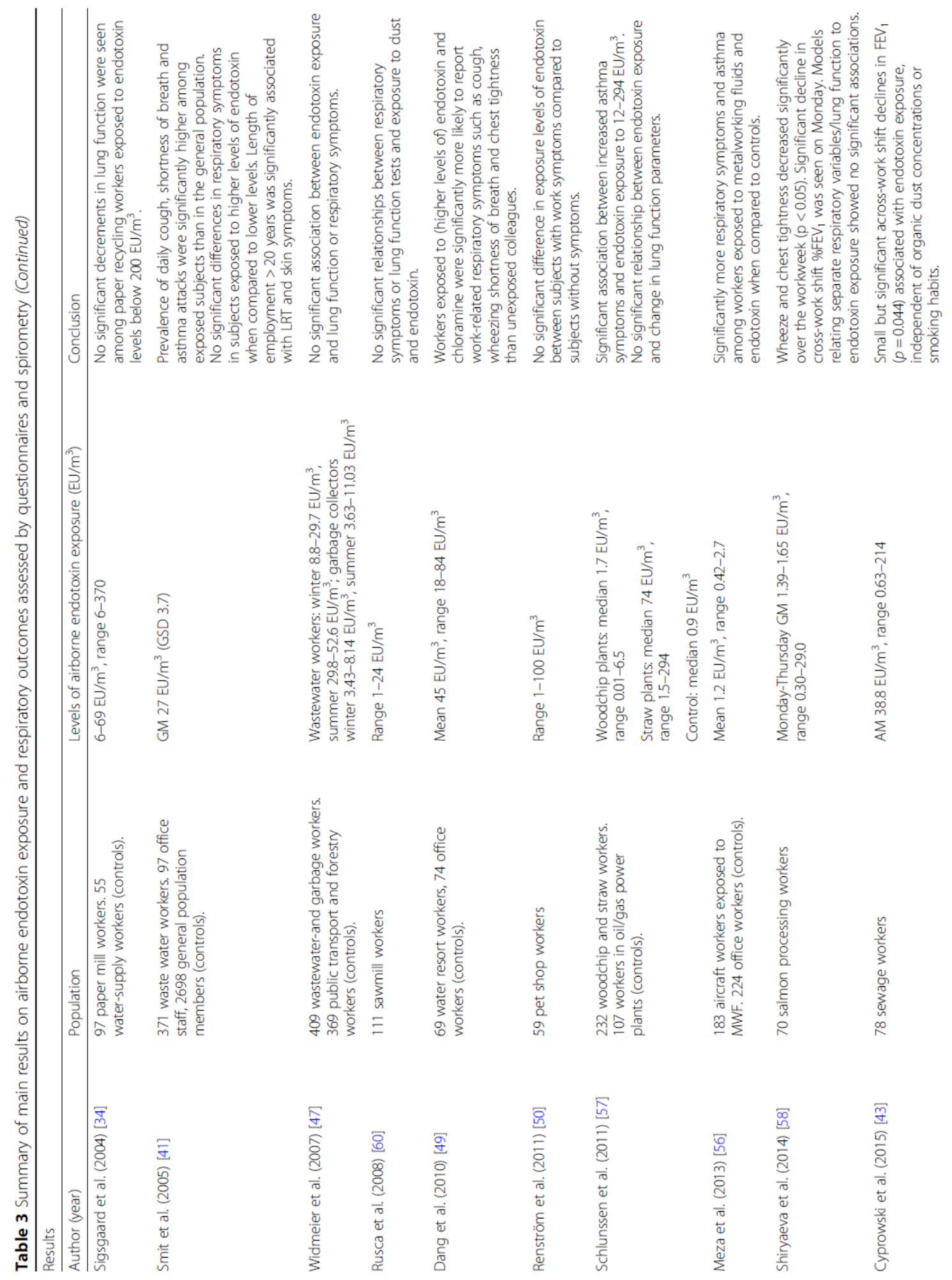




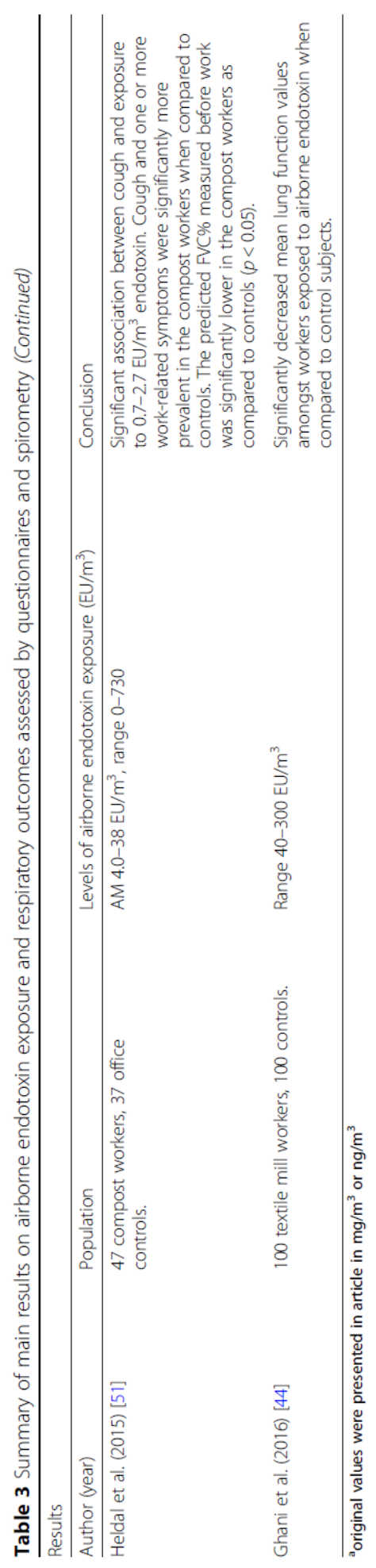




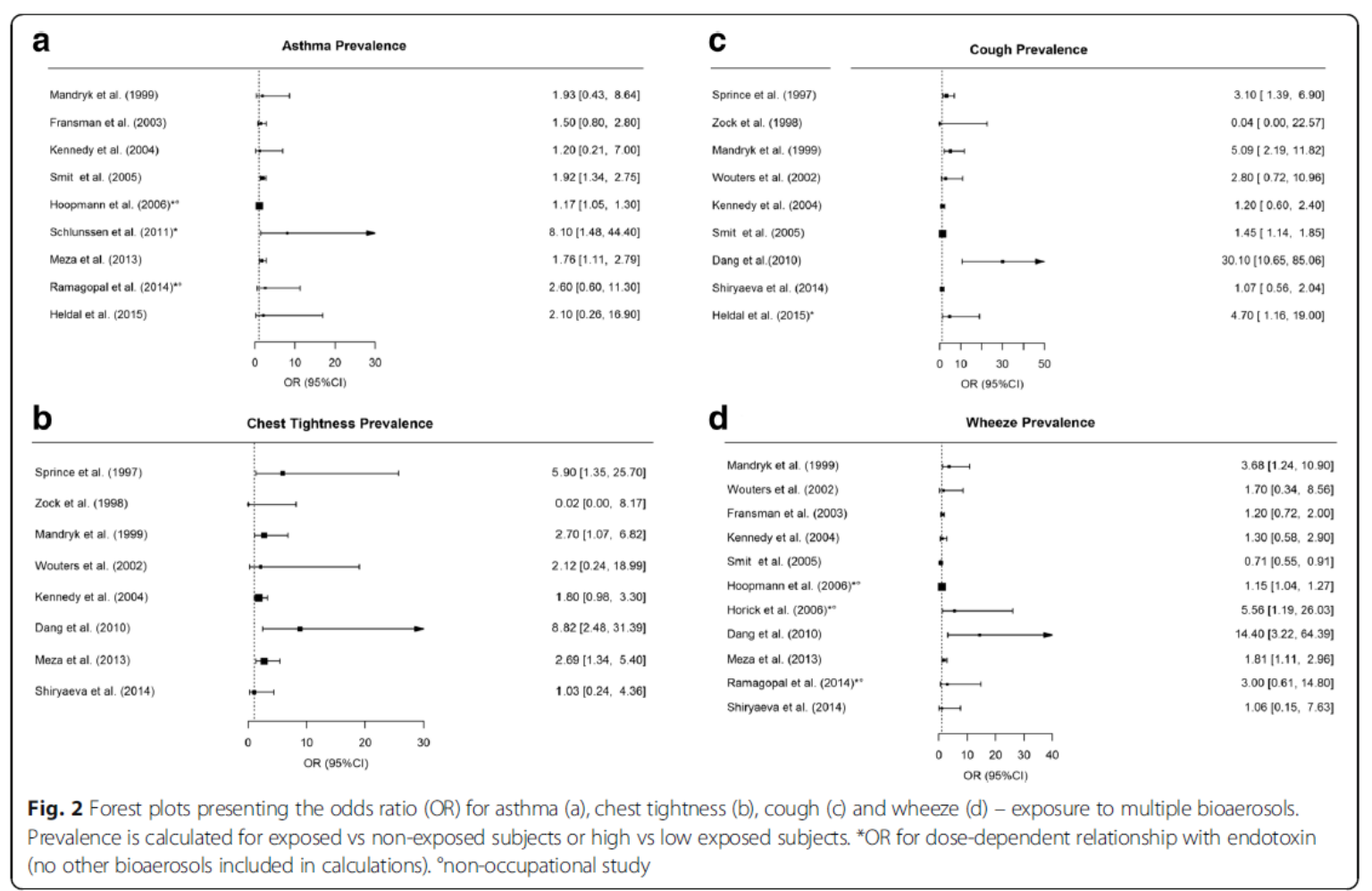

higher in subjects exposed to bioaerosols, albeit with wide confidence intervals and often not significant. Figure 3 shows the odds ratios for different symptoms for an increase in exposure of 1 unit of logtransformed endotoxin.

\section{Spirometry}

The results for the different outcomes of spirometry measurements are summarised in Additional file 1: Supplement S4.2. Three studies found a significant difference in pre-shift lung function values between exposed subjects and controls (exposure definition differed between studies), where exposed subjects had lower values for $\mathrm{FEV}_{1}$ and/or FVC [44, 51, 53]. The baseline FVC recorded by one study was $84.7 \%$ of predicted for woodworkers exposed to $24-43 \mathrm{EU} / \mathrm{m}^{3}$ endotoxin compared to $94.9 \%$ for controls $(p=0.0001)$, for $\mathrm{FEV}_{1}$ comparable outcomes were found [53].

Six studies presented significant cross-work shift declines of $\mathrm{FEV}_{1}$ and/or FVC among exposed subjects $[32,39,43,46,53,58]$. Mean absolute decrease in $\mathrm{FEV}_{1}$ was found to be $0.06-0.12 \mathrm{~L}$ among potato processing

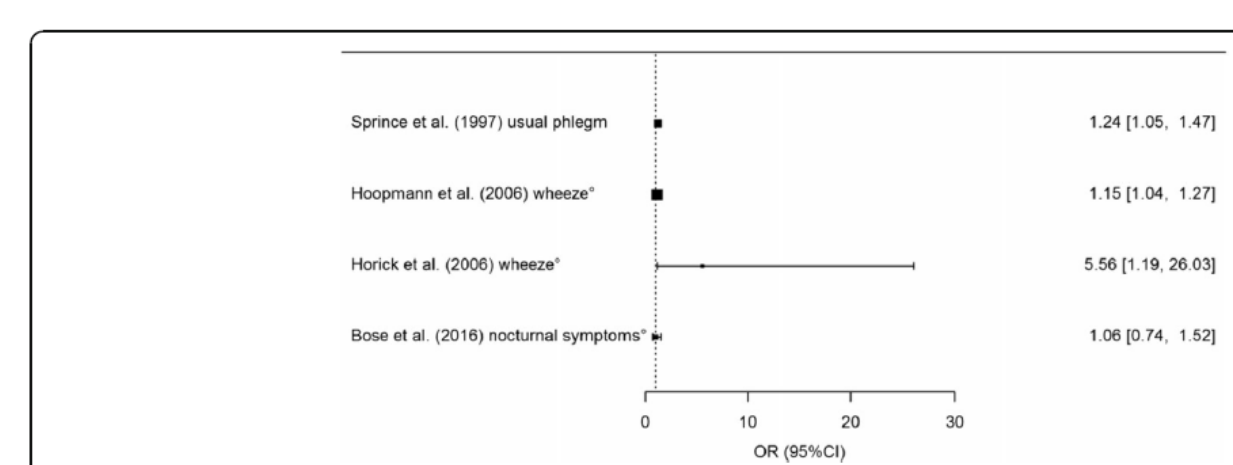

Fig. 3 Odds Ratio (OR) for symptoms per increase in exposure of 1 log endotoxin*. *For Horick et al. (2006), the symptoms OR per increase in 0.4 log endotoxin is presented. ${ }^{\circ}$ non-occupational study 
workers exposed to $56 \mathrm{EU} / \mathrm{m}^{3}$ [39], another study found an mean decrease of $0.07-0.10 \mathrm{~L}$ among textile yarn workers exposed to spray-humidifiers associated with endotoxin levels of $0.64 \mathrm{EU} / \mathrm{m}^{3}$ [32]. The latter study found a significant decrease in $\mathrm{FEV}_{1}$ over the workday but also a decreased $\mathrm{FEV}_{1}$ level on Friday when compared to Monday. Dahlqvist et al. found that subjects with a period of employment $>18$ years had a significantly larger change in MMEF over the workweek than subjects employed $<6$ years [52]. Another study that performed cross-week analyses did not find significant lung function decline over the workweek [58]. In terms of cross-work shift decline in percentage predicted lung function, one study found a cross-work shift decrease of $6.34 \%$ in $\mathrm{FEV}_{1}$ among woodworkers exposed to $24-$ $43 \mathrm{EU} / \mathrm{m}^{3}$ whereas controls had a decrease of $1.78 \%$ $(p<0.001)$ [53].

Exposure to $7.40 \mathrm{EU} / \mathrm{m}^{3}$ for $1 \mathrm{~h}$ in an experimental setting did not lead to significant changes in lung function parameters among 48 healthy volunteers [35].

Four studies found no significant effect of exposure to bioaerosols on lung function parameters among exposed subjects [42, 48, 54, 60]. Another study among 97 paper mill workers showed no significant difference in yearly decline of lung function between low and high exposed groups (endotoxin levels ranged between 6 and $370 \mathrm{EU} /$ $\mathrm{m}^{3}$ ) [33]. A longitudinal study also found no significant changes in lung function after 5 years of exposure to endotoxin levels of $28 \mathrm{EU} / \mathrm{m}^{3}$ among refuse derived fuel workers [40].

\section{Dose-response relationship}

Eighteen of the included studies performed analyses to study the dose-dependent exposure-response relationship between endotoxin exposure and respiratory health effects, the results are presented in Additional file 1 : Supplement S4.3. Symptoms that occurred significantly more often with increasing levels of endotoxin exposure were cough [51], asthmatic symptoms [37, 45, 47, 57], wheeze [37, 38, 47] and usual phlegm [54]. One study found an OR of 2.042 (95\%CI 1.029-4.042) for nocturnal asthma symptoms for every $1 \mathrm{EU} / \mathrm{m}^{3}$ increase in endotoxin exposure [45]. A relative risk of 5.56 (95\%CI 1.19-26.03) for wheeze was found for every $0.4 \log _{10}$ endotoxin increase in personal exposure in another study [38].

Five studies found a significant drop in $\mathrm{FEV}_{1}$ levels associated with an increase in endotoxin exposure [39, 43, $45,46,53]$. One study found that children exposed to higher levels of endotoxin had significantly lower levels of evening $\mathrm{FEV}_{1}$, with a decrease of $316 \mathrm{ml}$ per $1 \mathrm{EU} / \mathrm{m}^{3}$ increase (95\%CI -597 to $-36 \mathrm{ml}, p=0.036$ ) [45]. Cyprowski et al. found a $42 \mathrm{ml}$ decrease in $\mathrm{FEV}_{1}$ per 1 $\mathrm{EU} / \mathrm{m}^{3}$ increase in exposure $(p=0.044)$ [43].

\section{Subgroup analyses}

Wheeze, nocturnal cough and other asthmatic symptoms were more prevalent among children of atopic parents in a big German study where endotoxin exposure (median $0.064 \mathrm{EU} / \mathrm{m}^{3}$ ) was modelled using dispersion models. Per one log unit increase in endotoxin exposure the OR for asthmatic symptoms among children with atopic parents was 1.15 (95\%CI 1.03-1.29) [37].

One study among asthmatic school children found that subjects with baseline $\mathrm{FEV}_{1}<80 \%$ of predicted had significant associations with endotoxin exposure, predicted $\mathrm{FEV}_{1}$ values dropped with $7.7 \%$ (95\%CI -12.3 to - $3.3 \%$ ) for every $2.19 \mathrm{EU} / \mathrm{m}^{3}$ increase in exposure [46]. Another study among asthmatic school children found that airborne endotoxin was associated with increased maximum symptom-days only in subjects with non-atopic asthma. For atopics, there was an inverted U-shaped relationship between school air endotoxin and maximum symptom-days (plateau at $230 \mathrm{EU} / \mathrm{m}^{3}$ ) [47].

In an occupational study, $60 \%$ of exposed asthmatic workers reported that their asthma seemed worse at work, while none of the non-exposed asthmatic subjects reported this [49]. A second occupational study found that atopic exposed subjects had a significantly higher proportion with symptoms at work (PR 3.2 (95\%CI 1.66.2), $p<0.001)$ than non-atopics [50]. Another study showed that there were no significant differences in respiratory outcomes related to exposure between atopic and non-atopic subjects [58].

In the study by Schlünssen et al., asthma symptoms were found to be associated with endotoxin in nonsmokers (OR 10.1;1.7-59.7), whereas this was not found for smokers (OR 0.5; 0.1-2.8) [57]. Dahlqvist et al. found no differences in the distribution of symptoms between smokers and non-smokers [52]. In one study, nonsmokers showed larger across work shift declines than smokers: for $\mathrm{FEV}_{1}$ the across work shift difference was $-0.1 \%(95 \% \mathrm{CI}-3.6 ; 3.5)$ for smokers and $-1.8 \%(95 \% \mathrm{CI}$ $-4.5,1.0)$ for non-smokers [39]. On the contrary, in another study smokers showed an across work shift decline of $1.12 \%$ (SD 9.5) for FVC and 2.26\% (SD 12.1) for $\mathrm{FEV}_{1}$, whereas non-smokers showed an across work shift decline of $0.53 \%$ (SD 11.9) for FVC and $0.73 \%$ (SD 12.5) for $\mathrm{FEV}_{1}$ [40]. Similarly, smokers had a mean cross work shift decline in $\mathrm{FEV}_{1}$ of $0.93 \%$ (SD 5.24), this was $0.72 \%$ (SD 6.31) for former smokers and $0.41 \%$ (SD7.52) for non-smokers in a second study [58]. Yet another study showed comparable lung function declines for smokers and non-smokers [33].

One study found that smokers exposed to $3-11 \mathrm{EU} / \mathrm{m}^{3}$ endotoxin had significantly lower lung function values than non-exposed smokers. For ex-smokers, no significant difference was found according to exposure [42]. 
An overview of the results among subgroups is provided in Additional file 1: Supplement S4.4.

\section{Best evidence synthesis}

In Additional file 1: Supplement S5, an overview of the best evidence synthesis is presented.

For wheeze, there were two strong studies and one study of moderate quality showing a significant increase in complaints when personal endotoxin exposure increased [37, 38, 47]. Four other studies also showed dose-dependent increase of wheeze, although their results did not reach significance, which may be due to limited sample sizes in some of these studies [57, 58, 61, 62]. The evidence for the effects of endotoxin exposure on wheeze symptoms could be classified as weak, since less than $75 \%$ of the results found reached significance, but none of the studies showed results in the opposite direction.

For nocturnal asthma symptoms, there were one strong study and three studies of moderate quality showing a significant dose-dependent increase of symptoms $[37,45,47,57]$. Two other studies (in $<100$ subjects) showed an increase of symptoms as well, but their results did not reach significance [61, 62]. This was considered weak evidence for effects of exposure to endotoxin on asthma complaints since less than $75 \%$ of the results reached significance. No studies mentioned evidence for improvement of asthma symptoms related to endotoxin exposure, however.

Only one study, with a design classified as weak, found a significant dose-dependent effect of exposure to endotoxin on symptoms of cough [36]. Another strong study did suggest the same effect but did not reach statistical significance [58]. On the contrary, Zock et al. found that subjects exposed to lower levels of endotoxin had a higher prevalence of cough symptoms than subjects exposed to higher levels of endotoxin [39]. Overall, insufficient evidence was found to state an effect of endotoxin exposure on symptoms of cough.

There were also several studies investigating the dose-dependent effects of exposure to endotoxin on $\mathrm{FEV}_{1}$ levels. Four strong studies and one study of moderate quality found significant declines of $\mathrm{FEV}_{1}$ (cross-work shift or cross-day) in relation to increasing endotoxin exposure [39, 43, 45, 46, 53]. Two other studies (in 70 salmon workers and 128 cotton workers) found non-significant declines in $\mathrm{FEV}_{1}$ with increasing endotoxin exposure $[48,58]$. Overall, evidence regarding the effect of endotoxin on decline in $\mathrm{FEV}_{1}$ was considered to be weak since less than $75 \%$ of the results were significant, although multiple strong studies support the hypothesis that $\mathrm{FEV}_{1}$ declines with higher endotoxin exposure and no studies found results in the opposite direction.

\section{Discussion}

This review systematically summarizes the current knowledge on the respiratory effects of exposure to low levels of endotoxin. To our knowledge, no previous systematic review presented health effects of exposure to airborne endotoxin at levels that can be found in polluted ambient air, for instance near large-scale livestock farms or composting sites. Overall, negative effects on lung function and an increase in respiratory symptoms seem present although the evidence found was inconsistent in several ways.

By performing a best evidence synthesis we attempted to rate the level of evidence of the results found. Through this synthesis we could conclude that there is weak evidence regarding effects of low levels of airborne endotoxin on $\mathrm{FEV}_{1}$ values, although multiple strong studies showed significantly decreasing $\mathrm{FEV}_{1}$ values related to higher endotoxin exposures. For other outcomes too, only weak or insufficient evidence was found. This was mainly due to a lack of statistically significant findings, as many studies were underpowered, in particular for studying dichotomous outcomes. Still, most of the included studies did suggest negative effects of exposure to airborne endotoxin on wheeze, cough and (sleep-related) asthma symptoms. Apart from the exposureresponse associations included in the best evidence synthesis, several other studies indicated that exposure to airborne endotoxin can have respiratory effects at these levels of exposure. Overall, twelve out of eighteen studies found statistically significant dose-dependent effects of exposure to endotoxin on respiratory symptoms and/or lung function values.

\section{Strengths and limitations}

One of the limitations concerning this review is the use of only one database in the search for relevant literature. Although Pubmed is widely used and expected to include almost all relevant literature on the topic of interest by the authors, it might be that relevant literature was not identified because of the exclusion of other databases. Another limitation is the inclusion of mostly cross-sectional observational studies and the strength of evidence must be interpreted against that background, the findings of this study remain descriptive. Further research in the field of respiratory inflammation related to endotoxin exposure at low levels would strengthen the evidence, as would investigation to certain biomarkers to prove a causal relationship. Since the nature of the included studies was quite heterogeneous and the statistical methods, sample populations and exposure and outcome definitions varied too much in the different studies, a meta-analysis, or meta-regression, could not be performed. A limitation in the assessment of the quality of the studies is the absence of clear cut-off 
points for considering a study design strong, moderate or weak. To overcome this, overall quality scores were compared by calculating percentages and strict cut-off points were formulated. Other limitations of the approach in this systematic review are the influences of multiple testing, selective reporting and publication bias.

A strength in the design of this review is the systematic approach and conduction of the inclusion and assessment of the relevant literature and data extraction of the included articles. By this systematic approach, chances of missing relevant literature or data was minimalized. The careful quality assessment, which was conducted by two researchers to optimise critical appraisal, is another strength of this study and improves the interpretation of the results of the different included studies. Although most of the included studies were designed cross-sectionally, several longitudinal follow-up studies were included. Inclusion of these articles gives insight in longer term changes in lung function and adds to the clinical relevance of this review. Another strength of this review is the inclusion of only actual measured levels of airborne endotoxin, enabling the nearest approximation of the true exposure of the included subjects. The only other exposure measurement method which was acceptable was modelling of personal endotoxin exposures based on measured airborne endotoxin levels. Hoopmann et al. used a dispersion model to predict personal endotoxin exposures by using endotoxin emission measurements of neighbouring livestock farms. All studies used the functional LAL assay to measure endotoxin exposure. Although within-laboratory precision of the assay is good, variation between laboratories may be substantial, in particular if different extraction and analysis procedures are used [21]. Underestimation of endotoxin levels, especially when using older protocols, may have resulted in the inclusion of studies with true mean endotoxin levels above $100 \mathrm{EU} / \mathrm{m}^{3}$, although most studies had mean exposure levels far below this threshold. The best evidence synthesis was conducted to strengthen the statements on the evidence of the reported results. Only dose-dependent exposure-response relationships were used in the best evidence synthesis in order to rely only on those results that were fully attributable to exposure to endotoxin.

\section{Significant respiratory effects of other airborne agents}

This review aimed to summarize associations between endotoxin and respiratory health, but it should be noted that airborne endotoxin levels are generally correlated with other bioaerosol components such as fungi and bacteria. Ambient air contains multiple agents, and exclusive exposure to endotoxin is only found in experimental research. Although all the included studies considered endotoxin exposure as a potential cause of the respiratory outcomes, other possible causative agents were often considered as well and we came across interesting findings regarding other bioaerosol exposures, as shown in Additional file 1: Table S2.

\section{(Dis)agreement with current scientific literature}

The search for a relationship between organic dusts and disease is an ongoing challenge given the inherent aspect of exposure to multiple agents and the difficulty to prove causal relationships in observational epidemiological studies. However, the findings of this review are in line with previous research findings in higher exposed populations. Several occupational studies among farmers have shown increased prevalence of respiratory diseases related to exposure to endotoxin [3-6] and studies experimenting with direct inhalation of endotoxin have shown an inflammatory response in the airways [12]. In addition, Radon et al. investigated the prevalence of respiratory symptoms among inhabitants of rural areas. They found that the number of animal houses in the neighbourhood was a predictor of self-reported wheeze and decreased $\mathrm{FEV}_{1}$ [18]. More recently, a Dutch study revealed a relationship between living in the vicinity of a large number of neighbouring farms and lower MMEF values and also between ammonia and particulate air pollution and lower $\mathrm{FEV}_{1}$ values, potentially related to endotoxin exposure [2].

From our results it seems that individuals with atopy or a chronic lung disease might be more susceptible to effects of exposure to endotoxin. This is in line with the findings of a study among COPD patients presented by Borlée et al. in 2015 [1]. Here, COPD patients living in the vicinity of livestock farms were found to have more exacerbations and use more medication. More evidence should be sought to confirm that patients with asthma or COPD and atopics form a vulnerable subgroup for the effects of exposure to airborne endotoxin.

Living near a farm was also associated with a lower prevalence of allergic rhinitis $[1,63]$. Several studies in occupationally exposed farming populations have shown a dual effect of endotoxin with both negative and protective effects, but these populations were exposed to average endotoxin levels above $100 \mathrm{EU} / \mathrm{m}^{3}[16,17]$. Our focus on lung function and symptoms led to inclusion of studies showing adverse effects of endotoxin exposure. Furthermore, most studies that showed protective effects of endotoxin in homes analyzed endotoxin concentrations in house dust samples, whereas our systematic review only includes airborne endotoxin levels $[64,65]$.

\section{Future perspectives}

This study adds to the knowledge in the field by summarizing all the evidence available on respiratory effects of exposure to low levels of endotoxin, but future 
research is needed to strengthen the evidence. Endotoxin is known to originate from rural activities such as farming and composting and adds to air pollution in areas with a high density of these sources. Since possible effects are suggested by this review and other studies, endotoxin in ambient air should be seriously considered and investigated in larger populations. Large studies focussing on long-term exposed individuals are expected to give the best results. Since it is impossible to measure airborne personal exposure for a large group of individuals, modelling of personal exposure seems to be a good way to predict average long-term exposure levels. If a relationship between endotoxin and respiratory complaints becomes more evident, safety measures should be considered in order to protect inhabitants of areas with increased levels of these air pollutants. Another interesting topic for future research would be the effect of exposure to low levels of endotoxin on specific vulnerable subgroups, such as broncho-obstructive patients or atopics, since the respiratory effects seem different in these groups than in the general population.

\section{Conclusion}

Respiratory health effects of exposure to low levels of airborne endotoxin are found in multiple studies. More research regarding this relationship is needed in order to be able to inform/advise neighbouring residents of livestock farms and form guidelines and policies on ambient exposure to endotoxin. Special attention should be given to respiratory effects of endotoxin exposure in vulnerable subgroups, such as patients with bronchoobstructive disease.

\section{Additional file}

Additional file 1: Supplement 1. Pubmed search strategy. Supplement 2 Study incentives and other airborne exposures found to be associated with the outcome variables. Table S2. Study incentives and other airborne exposures found to be associated with the outcome variables. Supplement 3: Quality Assessment of included studies. Table S3. Quality Assessment of included studies based on the NIH Quality Assessment Tool for Observational Cohort and Cross-Sectional Studies. Supplement 4. Results tables Table S4.1. Overview of results - questionnaire outcomes among subjects exposed to bioaerosols. Table S4.2. Overview of results - spirometry outcomes among subjects exposed to bioaerosols. Table S4.3. Overview of results - exposureresponse relationships between endotoxin exposure and respiratory outcomes. Table S4.4 Analysis of effects of endotoxin exposure on respiratory health in subgroups. Supplement 5 : Best evidence synthesis. (DOCX $56 \mathrm{~kb}$ )

\section{Abbreviations}

ATS-DLD: American Thoracic Society Division of Lung Disease; COPD: Chronic Obstructive Pulmonary Disease; ECRHS: European Community Respiratory Health Survey; EU: Endotoxin Units; FeNO: Fractional exhaled nitric oxide; $F_{1 E}$ : Forced Expiratory Volume, in first second; FVC: Forced Vital Capacity; ISAAC: International Study of Asthma and Allergies in Childhood; LAL: Limulus Amebocyte Lysate; LRT: Lower respiratory tract; MEF: Midexpiratory flow; MMEF: Maximum midexpiratory flow $\left(=\mathrm{FEF}_{25}-75\right)$; $\mathrm{MRC}$ : Medical Research Council; MWF: Metal working fluids; NIH: National Institutes of Health;
PEF: Peak expiratory flow: PM: Particulate matter, PRISMA: Preferred Reporting Items for Systematic Reviews and Meta-Analyses; VC: Vital capacity

Acknowledgements

Not applicable.

Funding

This study was funded by the Dutch Ministry of Infrastructure and the Environment (grant no: DGAN-ANK / 16151555).

Availability of data and materials

All data generated or analysed during this study are included in this published article and its additional files.

Authors' contributions

AF and LS made the search query. AF performed study selection, data extraction and analysis, quality assessment of the included studies and the best evidence synthesis. $L S$ supervised the whole process and performed quality assessment of the included studies. All authors contributed to interpretation of the data, read and approved the final manuscript.

Ethics approval and consent to participate

Not applicable.

\section{Consent for publication}

Not applicable.

Competing interests

The authors declare that they have no competing interests.

\section{Publisher's Note}

Springer Nature remains neutral with regard to jurisdictional claims in published maps and institutional affiliations.

Received: 26 October 2017 Accepted: 30 January 2018

Published online: 08 February 2018

\section{References}

1. Borlée F, Yzermans CJ, Van Dijk CE, Heederik D, Smit LAM. Increased respiratory symptoms in COPD patients living in the vicinity of livestock farms. Eur Respir J. 2015;46(6):1605-14.

2. Borlée F, Yzermans C, Aalders B, Rooijackers J, Krop E, Maassen C, et al. Air pollution from livestock farms is associated with airway obstruction in neighboring residents. Am J Respir Crit Care Med. 2017;196:1152-61.

3. Basinas I, Sigsgaard T, Heederik D, Takai H, Omland $\varnothing$, Andersen NT, et al. Exposure to inhalable dust and endotoxin among Danish livestock farmers: results from the SUS cohort study. J Environ Monit. 2012;14:604.

4. Basinas I, Sigsgaard T, Kromhout H, Heederik D, Wouters IM, Schlü Nssen V. A comprehensive review of levels and determinants of personal exposure to dust and endotoxin in livestock farming. J Expo Sci Environ Epidemiol. 2015;25(10):123-37.

5. Eduard W, Pearce N, Douwes J. Chronic Bronchitis, COPD, and lung function in farmers: the role of biological agents. Chest. 2009;136(3)

6. Douwes J, Thorne P, Pearce N, Heederik D. Bioaerosol Health effects and exposure assessment: progress and prospects. Ann Occup Hyg. 2003;47(3): 187-200.

7. Soukup JM, Becker S. Human alveolar macrophage responses to air pollution particulates are associated with insoluble components of coarse material, including particulate endotoxin. Toxicol Appl Pharmacol. 2001;171(1):20-6.

8. Kumar S, Adhikari A. Dose-dependent immunomodulating effects of endotoxin in allergic airway inflammation. Innate Immun. 2017;23(3):249-57.

9. Xu H, Liew LN, Kuo IC, Huang CH, Goh DLM, Chua KY. The modulatory effects of lipopolysaccharide-stimulated B cells on differential T-cell polarization. Immunology. 2008;125(2):218-28

10. Schins RPF, Lightbody JH, Borm PJA, Shi T, Donaldson K, Stone V. Inflammatory Effects of coarse and fine particulate matter in relation to chemical and biological constituents. Toxicol Appl Pharmacol. 2004;195:1-11.

11. Sigsgaard T, Bonefeld-Jørgensen EC, Hoffmann HJ, Bønløkke J, Krüger T. Microbial cell wall agents as an occupational hazard. Toxicol Appl Pharmacol. 2005;207(2):310-9. 
12. Sandstrom T, Bjermer L, Rylander R. Lipopolysaccharide (LPS) inhalation in healthy subjects increases neutrophils, lymphocytes and fibronectin levels in bronchoalveolar lavage fluid. Eur Respir J. 1992;5(8):992-6.

13. Castellan RM, Olenchock SA, Kinsley KB, Hankinson JL. Inhaled endotoxin and decreased spirometric values. An exposure-response relation for cotton dust. N Engl J Med. 1987:317(10):605-10.

14. Bolund ACS, Miller MR, Basinas I, Elholm G, Omland O, Sigsgaard T, et al. The effect of occupational faming on lung function development in young adults: a 15-year follow-up study. Occup Environ Med. 2015;72(10):707-13.

15. Omland $\mathrm{O}$. Exposure and Respiratory health in farming in temperate zones-a review of the literature. Ann Agric Environ Med. 2002;9(2):119-36.

16. Elholm G, Schlünssen V, Doekes G, Basinas I, Bolund A, Hjort C, et al. High exposure to endotoxin in farming is associated with less new-onset pollen sensitisation. Occup Env Med. 2018;75(2):139-47.

17. Smit LAM, Heederik D, Doekes G, Blom C, Van Zweden I, Wouters IM. Exposure response analysis of allergy and respiratory symptoms in endotoxin exposed adults. Eur Respir J. 2008;31(6):1241-8.

18. Radon K, Schulze A, Ehrenstein V, Van Strien RT, Praml G, Nowak D. Environmental exposure to confined animal feeding operations and respiratory health of neighboring residents. Epidemiology. 2007;18(3): $300-8$.

19. de Rooij MMT, Heederik DJJ, Borlée F, Hoek G, Wouters IM. Spatial and temporal variation in Endotoxin and PM10 concentrations in ambient air in a livestock dense area. Environ Res. 2017;153:161-70.

20. Pearson C, Littlewood E, Douglas P, Robertson S, Gant T, Hansell A. Exposures and health outcomes in relation to bioaerosol emissions from composting facilities: a systematic review of occupational and community studies. J Toxicol Env Heal B Crit Rev. 2015;18(1):43-69.

21. Health Council of the Netherlands. Endotoxins. Health-based recommended occupational exposure limit. Hague: Health Council of the Netherlands. 2010/04OSH; 2010.

22. Gezondheidsraad. Gezondheidsrisico's rond veehouderijen. 2012. Available from: https://www.gezondheidsraad.nl/sites/default/files/201227Gezondheid srisicoveehouderijen.pdf. Accessed 1 Feb 2017.

23. Thorne P, Ansley A, Perry SS. Concentrations of bioaerosols, odors and hydrogen sulfide inside and downwind from two types of swine livestock operations. J Occup Env Hyg. 2009,6(4):211-20.

24. Heederik D, Opstal-vanWinden AJ, Smit LAM, Wouters IM, Hooiveld M, IJzermans $\mathrm{C}$, et al. Potential effects of intensive livestockfarming on neighboring residents' health. Utrecht: IRAS Universiteit Utrecht, NIVEL, RIVM. 2011; p. 204.

25. Liberati A, Altman DG, Tetzlaff J, Mulrow C, Gøtzsche PC, loannidis JPA, et al. The PRISMA statement for reporting systematic reviews and meta-analyses of studies that evaluate health care interventions: explanation and elaboration. BM. 2009,339:b2700.

26. NIH Quality assessment Tool for Observational Cohort and Cross-Sectional Studies. National Institutes of Health. Available from: https://www.nhlbinih. gov/health-pro/guidelines/in-develop/cardiovascular-risk-reduction/tools/ cohort. Accessed 1 Feb 2017.

27. Proper Kl, Singh AS, Mechelen van W, Chinapaw MJM. Sedentary behaviors and health outcomes among adults. A Systematic Review of Prospective Studies. Am J Prev Med. 2011;40(2):174-82

28. Proper K, Koning M, Van der Beek A, Hildebrandt V, Bosscher R, Van Mechelen W. The effectiveness of worksite physical activity programs on physical activity physical fitness and health. Clin J Sport Med. 2003;13(2):106-17.

29. Hoogendoom W, van Poppel M, Bongers P, Koes B, Bouter L. Systematic review of psychosocial factors at work and private life as risk factors for back pain. Spine (Phila Pa 1976). 2000;25:21 14-25.

30. Udeni Alwis K, Mandryk J, Hocking A. Exposure to Biohazards in Wood Dust: Bacteria, Fungi, Endotoxins, and (1->3)-B-D-GlucansAppl Occup Environ Hyg 1999;14(9):598-608.

31. Mandryk J, Alwis KU, Hocking AD. Effects of personal exposures on pulmonary function and work-related symptoms among sawmill workers. Ann Occup Hyg. 2000;44(4):281-9.

32. Kateman E, Heederik D, Pal TM, Smeets M, Smid T, Spitteler M. Relationship of airborne microorganisms with the lung function and leucocyte levels of workers with a history of humidifier fever. Scand J Work Environ Health. 1990;16(6):428-33.

33. Sigsgaard T, Jensen LD, Abell A, Wurtz H, Thomsen G. Endotoxins isolated from the air of a Danish paper mill and the relation to change in lung function: an 11-year follow-up. Am J Ind Med. 2004;46(4):327-32.
34. Kennedy SM, Copes R, Bartlett KH, Brauer M. Point-of-sale glass bottle recycling: indoor airbome exposures and symptoms among employees. Occup Environ Med. 2004,61(7):628-35.

35. Schiffman SS, Studwell CE, Landerman LR, Berman K, Sundy JS. Symptomatic effects of exposure to diluted air sampled from a swine confinement atmosphere on healthy human subjects. Environ Health Perspect. 2005: 113(5):567-76.

36. Heldal KK, Eduard W. Associations between acute symptoms and bioaerosol exposure during the collection of household waste. Am J Ind Med. 2004; 46(3):253-60.

37. Hoopmann M, Hehl O, Neisel F, Werfel T. Associations between bioaerosols coming from livestock facilities and asthmatic symptoms in children. Gesundheitswesen. 2006;68(8-9):575-84

38. Horick N, Weller E, Milton DK Gold DR, Li R, Spiegelman D. Home Endotoxin exposure and wheeze in infants: correction for bias due to exposure measurement error. Environ Health Perspect. 2006;114(1):135-40.

39. Zock JP, Hollander A, Heederik D, Douwes J. Acute lung function changes and low endotoxin exposures in the potato processing industry. Am J Ind Med. 1998:33(4):384-91.

40. Mahar S. Worker Health in refuse-derived fuel plants, a five-year followup. Arh Hig Rada Toksikol. 2002;53(3):191-6.

41. Smit LAM, Spaan S, Heederik D. Endotoxin exposure and symptoms in wastewater treatment workers. Am J Ind Med. 2005:48(1):30-9.

42. Widmeier S, Bernard A, Tschopp A, Jeggli S, Dumont X, Hiffiker S, et al. Surfactan protein a, exposure to endotoxin, and asthma in garbage collectors and in wastewater workers. Inhal Toxicol. 2007;19(4):351-60.

43. Cyprowski M, Sobala W, Buczynska A, Szadkowska-Stanczyk I. Endotoxin exposure and changes in short-term pulmonary function among sewage workers. Int J Occup Med Environ Health. 2015;28(5):803-11.

44. Ghani N, Khalid A, Tahir A. Cross-sectional Study on the endotoxin exposure and lung function impairment in the workers of textile industry near Lahore, Pakistan. J Pak Med Assoc. 2016,66(7):803-14.

45. Rabinovitch N, Liu AH, Zhang L, Rodes CE, Foarde K, Dutton SJ, et al, Importance of the personal endotoxin cloud in school-age children with asthma. J Allergy Clin Immunol. 2005;1 16(5):1053-7.

46. Delfino RI, Staimer N, Tioa T, Gillen DL Relations of exhaled nitric oxide and FEV1 to personal endotoxin exposure in schoolchildren with asthma. Occup Environ Med. 2015;72(12):830-6.

47. Lai PS, Sheehan WJ, Gaffin JM, Petty CR, Coull BA, Gold DR, et al. School endotoxin exposure and asthma morbidity in inner-city children. Chest. 2015;148(5):1251-8.

48. Kawamoto MM, Garabrant DH, Held J, Balmes JR, Patzman J, Dimick DV, et al. Respiratory effects of cotton dust exposure in the cotton garnetting industry. Am J Ind Med. 1987;11(5):505-15.

49. Dang B, Chen L, Mueller C, Dunn KH, Almaguer D, Roberts JL, et al. Ocular and respiratory symptoms among lifeguards at a hotel indoor waterpark resort. J Occup Environ Med. 2010;52(2):207-13.

50. Renstrom A, Olsson M, Hedren M, Johansson SGO, van Hage M. Pet shop workers: exposure, sensitization, and work-related symptoms. Allergy. 2011; 66(8):1081-7.

51. Heldal KK, Madso L, Eduard W. Airway inflammation among compost workers exposed to actinomycetes spores. Ann Agric Environ Med. 2015;22(2):253-8

52. Dahlqvist M, Johard U, Alexandersson R, Bergstrom B, Ekholm U, Eklund A, et al. Lung function and precipitating antibodies in low exposed wood trimmers in Sweden. Am J Ind Med. 1992;21 (4):549-59.

53. Mandryk J, Alwis KU, Hocking AD. Work-related symptoms and dose-response relationships for personal exposures and pulmonary function among woodworkers. Am J Ind Med. 1999:35(5):481-90.

54. Sprince NL, Thorne PS, Popendorf W, Zwerling C, Miller ER, DeKoster JA. Respiratory symptoms and lung function abnormalities among machine operators in automobile production. Am J Ind Med. 1997;31(4):403-13.

55. Fransman W, Mdean D, Douwes J, Demers PA, Leung V, Pearce N. Respiraton Symptoms and occupational exposures in New Zealand plywood mill workers. Ann Occup Hyg. 2003;47(4):287-95.

56. Meza F, Chen $L$, Hudson $N$. Investigation of respiratory and dermal symptoms associated with metal working fluids at an aircaft engine manufacturing facility. Am J Ind Med. 2013:56(12):1394-401.

57. Schlunssen V, Madsen AM, Skov S, Sigsgaard T. Does the use of biofuels affect respiratory health among male Danish energy plant workers? Occup Environ Med. 2011;68(7):467-73. 
58. Shiryaeva O, Aasmoe L, Straume B, Olsen A-H, Ovrum A, Kramvik E, et al. Respiratory effects of bioaerosols: exposure-response study among salmonprocessing workers. Am J Ind Med. 2014;57(3):276-85

59. Wouters IM, Hilhorst SKM, Kleppe P, Doekes G, Douwes J, Peretz C, et al. Upper airway inflammation and respiratory symptoms in domestic waste collectors. Occup Environ Med. 2002;59(2):106-12.

60. Rusca S, Charriere N, Droz PO, Oppliger A. Effects of bioaerosol exposure on work-related symptoms among Swiss sawmill workers. Int Arch Occup Environ Health. 2008;81(4):415-21.

61. Ramagopal M, Wang Z, Black K, Hernandez M, Stambler AA, Emoekpere $\mathrm{OH}$ et al, Improved exposure characterization with robotic (PIPER) sampling and association with children's respiratory symptoms, asthma and eczema. J Expo Sci Environ Epidemiol. 2014;24(4):421-7.

62. Bose S, Rivera-Mariani F, Chen R, Williams D, Belli A, Aloe C, et al. Domestic exposure to endotoxin and respiratory morbidity in former smokers with COPD. Indoor Air. 2016;26(5):734-42.

63. Smit LAM, Hooiveld M, van der Sman-de Beer F, Opstal-van Winden AWJ, Beekhuizen J, Wouters IM, et al. Air pollution from livestock farms, and asthma, allergic rhinitis and COPD among neighbouring residents. Occup Environ Med. 2014;71(1):134-40.

64. Braun-Fahrländer C, Riedler J, Herz U, Eder W, Waser M, Grize L, et al. Environmental exposure to endotoxin and its relation to asthma in school-age children. N Engl J Med. 2002;347(12):869-77.

65. Stein MM, Hrusch $\mathrm{CL}$, Gozdz J, Igartua C, Pivniouk V, Murray SE, et al. Innate immunity and asthma risk in Amish and Hutterite farm children. N Engl J Med. 2016;375(5):411-21 
Appendix 4. Bijlage bij hoofdstuk 'effecten endotoxine bij lage concentraties' en Appendix 3.

Tabel A4.1. Pubmed zoekstrategie

\begin{tabular}{|l|l|}
\hline Endotoxin & Endotoxin \\
& Endotoxins \\
\hline Respiratory symptoms and lung function & Respiratory symptoms \\
& Asthma \\
& Wheeze \\
& Cough \\
& Dyspnoea \\
& Chest tightness \\
& Lung function \\
& Spirometry \\
& Pulmonary function \\
& FEV1 \\
\hline Exposure & PEF \\
\hline & FVC \\
& Forced expiratory volume \\
& Spirometer \\
\hline & Exposure* \\
\hline
\end{tabular}




\section{Search query:}

(((endotoxin OR endotoxins) AND ("respiratory symptoms" OR asthma OR wheeze OR cough OR dyspnoea OR "chest tightness" OR "lung function" OR spirometry OR "pulmonary function" OR FEV1 OR PEF OR FVC OR "forced expiratory volume" OR "forced vital capacity" OR spirometer) AND (exposure* OR exposed OR level* OR concentration*)))

\section{$\underline{\text { Result: } 1362 \text { articles }}$}

\section{Search query (including language selection):}

(((endotoxin OR endotoxins) AND ("respiratory symptoms" OR asthma OR wheeze OR cough OR dyspnoea OR "chest tightness" OR "lung function" OR spirometry OR "pulmonary function" OR FEV1 OR PEF OR FVC OR "forced expiratory volume" OR "forced vital capacity" OR spirometer) AND (exposure* OR exposed OR level* OR concentration*))) AND (English[Language] OR Dutch[Language] OR German[Language] OR French[Language])

\section{$\underline{\text { Result: } 1322 \text { articles }}$}




\section{Tabel A4.2. Studie incentives en andere blootstellingsvariabelen geassocieerd met de uitkomstvariabelen}

\begin{tabular}{|c|c|}
\hline Study & Study incentives and other exposures associated with outcome. \\
\hline Kateman et al. (1990) 57 & $\begin{array}{l}\text { This study was initiated after several cases of an influenza-like illness } \\
\text { occurred among workers after working in an area with a specific cold- } \\
\text { water spray humidifier. }\end{array}$ \\
\hline Dahlqvist et al. (1992) ${ }^{58}$ & $\begin{array}{l}\text { This study focussed on effects of exposure to moulds and significant } \\
\text { findings were found among the subjects proven to be sensitive to } \\
\text { moulds (precipitating antibodies positive). }\end{array}$ \\
\hline Sprince et al. (1997) $)^{59}$ & $\begin{array}{l}\text { Significant exposure-response relationships were found between } \\
\text { respiratory symptoms and total aerosol, culturable fungi and bacteria. }\end{array}$ \\
\hline Mahar et al. $(2002)^{60}$ & $\begin{array}{l}\text { Concerns about the health impact of processing solid waste into refuse- } \\
\text { derived fuel led to a health records study in } 1995 \text {. This study represents } \\
\text { continuation of the earlier study in } 1995 .\end{array}$ \\
\hline Heldal et al. (2004)61 & $\begin{array}{l}\text { A significant association between exposure to fungal spores and cough } \\
\text { was found. }\end{array}$ \\
\hline Sigsgaard et al. (2004)62 & $\begin{array}{l}\text { Workers in this plant suffered from a range of respiratory symptoms after changing to } \\
\text { recycled paper. In 1994, evidence was found that symptoms were related to endotoxin } \\
\text { exposure in a dose-dependent manner. }\end{array}$ \\
\hline Rabinovitch et al. (2005)63 & $\begin{array}{l}\text { Measurements were performed at a school for children with significant } \\
\text { asthma that interferes with regular school attendance and progress. }\end{array}$ \\
\hline Rusca et al. (2008) $)^{64}$ & $\begin{array}{l}\text { The analysis of the association between prevalence of self-reported } \\
\text { bronchial syndrome and airborne fungi concentration revealed a strong } \\
\text { positive dose-response relationship. }\end{array}$ \\
\hline Dang et al. (2010)65 & $\begin{array}{l}\text { After opening of this waterpark, eye and respiratory irritation symptoms } \\
\text { were increasingly reported. Suspicion of trichloramine and endotoxin as } \\
\text { a cause. }\end{array}$ \\
\hline Heldal et al. (2015)66 & $\begin{array}{l}\text { Significant associations between exposure to actinomycetes and work- } \\
\text { related nasal and cough symptoms and lung function decline was found. }\end{array}$ \\
\hline
\end{tabular}


Tabel A4.3. Quality Assessment van geïncludeerde studies gebaseerd op het 'NIH Quality Assessment Tool for Observational Cohort and Cross-Sectional Studies'

\begin{tabular}{|c|c|c|c|c|c|c|c|c|c|c|c|c|c|c|c|c|c|}
\hline Author (year) & 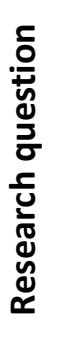 & 齐 & 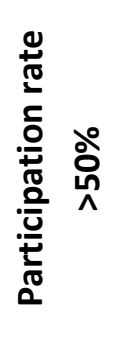 & 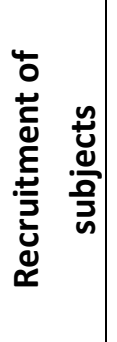 & 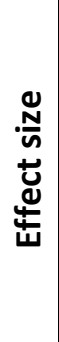 & 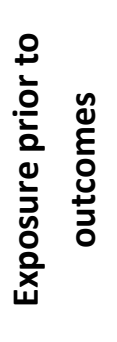 & 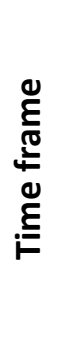 & 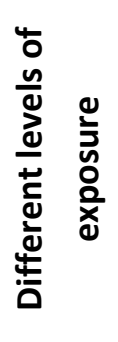 & 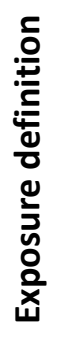 & 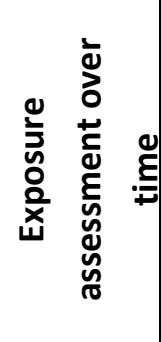 & 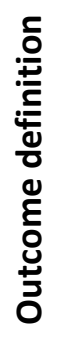 & مِ & 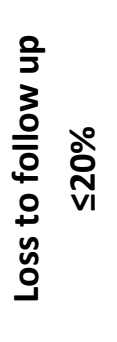 & 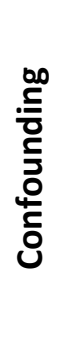 & 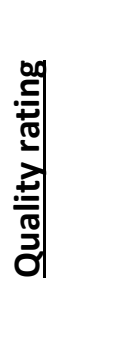 & 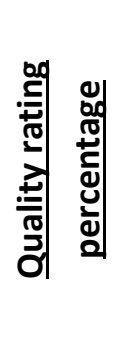 & 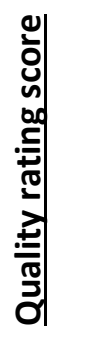 \\
\hline $\begin{array}{l}\text { Kawamoto et al. } \\
\text { (1987) }\end{array}$ & + & + & + & + & + & NA & + & + & + & - & + & - & NA & + & $\underline{10 / 12}$ & $\underline{83 \%}$ & $\underline{M}$ \\
\hline $\begin{array}{l}\text { Kateman et al. } \\
\text { (1990) }\end{array}$ & + & - & NR & + & + & NA & + & - & + & + & + & - & NA & + & $\underline{8 / 12}$ & $\underline{67 \%}$ & $\underline{W}$ \\
\hline $\begin{array}{l}\text { Dahlqvist et al. } \\
\text { (1992) }\end{array}$ & + & - & NR & + & + & NA & + & - & + & + & + & - & NA & + & $\underline{8 / 12}$ & $\underline{67 \%}$ & $\underline{W}$ \\
\hline $\begin{array}{l}\text { Sprince et al. } \\
\text { (1997) }\end{array}$ & + & + & + & + & + & NA & + & + & + & - & + & - & NA & + & $10 / 12$ & $83 \%$ & $\underline{M}$ \\
\hline Zock et al. (1998) & + & + & + & + & + & NA & + & + & + & + & + & - & NA & + & $\underline{11 / 12}$ & $\underline{92 \%}$ & $\underline{\mathrm{S}}$ \\
\hline $\begin{array}{l}\text { Mandryk et al. } \\
\text { (1999) }\end{array}$ & + & + & + & + & + & NA & + & + & + & + & + & - & NA & + & $\underline{11 / 12}$ & $\underline{92 \%}$ & $\underline{\mathrm{S}}$ \\
\hline $\begin{array}{l}\text { Mahar et al. } \\
\text { (2002) }\end{array}$ & + & + & NR & + & + & + & + & - & + & + & + & - & NR & - & $\underline{9 / 14}$ & $\underline{64 \%}$ & $\underline{W}$ \\
\hline
\end{tabular}




\begin{tabular}{|c|c|c|c|c|c|c|c|c|c|c|c|c|c|c|c|c|c|}
\hline $\begin{array}{l}\text { Wouters et al. } \\
(2002)\end{array}$ & + & + & NR & + & + & NA & NA & - & + & + & + & - & NA & NR & 7/11 & $\underline{64 \%}$ & $\underline{W}$ \\
\hline $\begin{array}{l}\text { Fransman et al. } \\
\text { (2003) }\end{array}$ & + & + & + & + & + & NA & NA & + & + & + & + & - & NA & + & $\underline{10 / 11}$ & $\underline{91 \%}$ & $\underline{\mathrm{S}}$ \\
\hline Heldal et al. (2004) & + & - & NR & + & - & NA & NA & - & + & + & + & - & NA & + & $6 / 11$ & $\underline{55 \%}$ & $\underline{W}$ \\
\hline $\begin{array}{l}\text { Kennedy et al. } \\
\text { (2004) }\end{array}$ & + & + & + & + & + & NA & + & + & + & + & + & - & + & + & $\underline{12 / 13}$ & $\underline{92 \%}$ & $\underline{\mathrm{S}}$ \\
\hline $\begin{array}{l}\text { Sigsgaard et al. } \\
(2004)\end{array}$ & + & + & + & + & + & + & + & + & + & + & + & - & - & + & $\underline{12 / 14}$ & $86 \%$ & $\mathrm{M}$ \\
\hline $\begin{array}{l}\text { Rabinovitch et al. } \\
(2005)\end{array}$ & + & + & NR & + & + & NA & NA & + & + & + & + & + & NA & - & $\underline{9 / 11}$ & $\underline{82 \%}$ & $\underline{M}$ \\
\hline $\begin{array}{l}\text { Schiffman et al. } \\
\text { (2005) }\end{array}$ & + & + & + & + & + & NA & + & - & + & - & + & - & NA & NR & $8 / 12$ & $\underline{67 \%}$ & $\underline{W}$ \\
\hline Smit et al. (2005) & + & + & + & + & + & NA & NA & + & + & + & + & - & NA & + & $\underline{10 / 11}$ & $\underline{91 \%}$ & $\underline{\mathrm{S}}$ \\
\hline $\begin{array}{l}\text { Hoopmann et al. } \\
\text { (2006) }\end{array}$ & + & + & + & + & + & NA & NA & + & + & + & + & + & NA & + & $\underline{11 / 11}$ & $\underline{100 \%}$ & $\underline{\mathrm{S}}$ \\
\hline Horick et al. (2006) & + & + & + & + & + & + & + & + & + & + & + & + & + & + & $14 / 14$ & $\underline{100 \%}$ & $\underline{\mathrm{S}}$ \\
\hline $\begin{array}{l}\text { Widmeier et al. } \\
\text { (2007) }\end{array}$ & + & + & + & + & + & NA & NA & - & + & + & + & - & NA & + & $9 / 11$ & $\underline{82 \%}$ & $\underline{M}$ \\
\hline Rusca et al. (2008) & + & + & + & + & + & NA & NA & + & + & - & + & - & NA & + & $9 / 11$ & $82 \%$ & $\underline{M}$ \\
\hline Dang et al. (2010) & + & + & NR & + & + & NA & NA & - & + & - & - & - & NA & + & $\underline{6 / 11}$ & $\underline{55 \%}$ & $\underline{W}$ \\
\hline
\end{tabular}




\begin{tabular}{|c|c|c|c|c|c|c|c|c|c|c|c|c|c|c|c|c|c|}
\hline $\begin{array}{l}\text { Renström et al. } \\
\text { (2011) }\end{array}$ & + & - & + & + & + & NA & NA & - & + & + & + & - & NA & + & $8 / 11$ & $\underline{72 \%}$ & $\underline{M}$ \\
\hline $\begin{array}{l}\text { Schlunssen et al. } \\
\text { (2011) }\end{array}$ & + & + & + & + & + & NA & NA & + & + & - & + & - & NA & + & $\underline{9 / 11}$ & $\underline{82 \%}$ & $\underline{M}$ \\
\hline Meza et al. (2013) & + & - & + & + & + & NA & NA & - & + & - & + & - & NA & + & $\underline{7 / 11}$ & $\underline{64 \%}$ & $\underline{W}$ \\
\hline $\begin{array}{l}\text { Ramagopal et al. } \\
\text { (2014) }\end{array}$ & + & + & NR & + & + & NA & NA & + & + & - & + & + & NA & + & $\underline{9 / 11}$ & $\underline{82 \%}$ & $\underline{M}$ \\
\hline $\begin{array}{l}\text { Shiryaeva et al. } \\
\text { (2014) }\end{array}$ & + & + & + & + & + & NA & + & + & + & + & + & - & NA & + & $\underline{11 / 12}$ & $\underline{92 \%}$ & $\underline{S}$ \\
\hline $\begin{array}{l}\text { Cyprowski et al. } \\
\text { (2015) }\end{array}$ & + & - & NR & + & + & NA & + & + & + & + & + & - & NA & + & $\underline{9 / 12}$ & $\underline{75 \%}$ & $\underline{M}$ \\
\hline $\begin{array}{l}\text { Delfino et al. } \\
\text { (2015) }\end{array}$ & + & + & NR & + & + & NA & NA & + & + & + & + & + & + & + & $11 / 12$ & $\underline{92 \%}$ & $\underline{S}$ \\
\hline Heldal et al. (2015) & + & - & + & + & + & NA & + & + & + & + & + & - & NA & + & $10 / 12$ & $\underline{83 \%}$ & $\underline{M}$ \\
\hline Lai et al. (2015) & + & + & + & + & + & NA & + & + & + & - & + & + & - & + & $11 / 13$ & $85 \%$ & $\underline{M}$ \\
\hline Bose et al. (2016) & + & + & + & + & + & + & + & + & + & - & + & + & NR & + & $12 / 14$ & $\underline{86 \%}$ & $\underline{M}$ \\
\hline Ghani et al. (2016) & + & + & NR & + & + & NA & NA & - & + & - & + & - & NA & + & $\underline{7 / 11}$ & $\underline{64 \%}$ & $\underline{W}$ \\
\hline
\end{tabular}

Quality rating score: $\geq 90 \%$ = strong $(\mathrm{S}), 70-90 \%=$ moderate $(\mathrm{M}),<70 \%=$ weak $(\mathrm{W})$ 
Tabel A4.4. Overzicht van de resultaten - vragenlijstuitkomsten

\begin{tabular}{|c|c|c|c|}
\hline \multicolumn{4}{|c|}{ Results Questionnaire } \\
\hline Author (year) & Population & $\begin{array}{l}\text { Levels of airborne endotoxin } \\
\text { exposure }\left(E U / m^{3}\right)\end{array}$ & Conclusion \\
\hline \multicolumn{4}{|c|}{ Non-occupational populations } \\
\hline $\begin{array}{l}\text { Schiffman et al. } \\
\text { (2005) }\end{array}$ & 48 healthy subjects. & $7.40 \mathrm{EU} / \mathrm{m}^{3}$ & $\begin{array}{l}\text { No significant difference in the prevalence of cough between } \\
\text { experimental (exposed) and control (unexposed) measurements. }\end{array}$ \\
\hline $\begin{array}{l}\text { Hoopmann et } \\
\text { al. (2006) }\end{array}$ & 3867 children. & $\begin{array}{l}\text { Median } 0.064 \mathrm{EU} / \mathrm{m}^{3} \text {, IQR } 0.025- \\
0.141^{*}\end{array}$ & $\begin{array}{l}15.9 \% \text { of the boys and } 12.9 \% \text { of the girls reported wheezing in the last } \\
12 \text { months. Wheezing, nocturnal coughing and asthmatic symptoms } \\
\text { were more prevalent in children of atopic parents (all } p<0.001 \text { ). }\end{array}$ \\
\hline \multicolumn{4}{|c|}{ Occupational populations } \\
\hline $\begin{array}{l}\text { Kateman et al. } \\
(1990)^{57}\end{array}$ & $\begin{array}{l}40 \text { textile yarn } \\
\text { workers exposed to } \\
\text { spray-humidifier, } 42 \\
\text { controls exposed to } \\
\text { other or no } \\
\text { humidifier. }\end{array}$ & $\begin{array}{l}\text { GM 0.64 EU } / \mathrm{m}^{3} \text { (GSD 0.016) for } \\
\text { cold-water humidification area, } \\
0.18-0.19 \mathrm{EU} / \mathrm{m}^{3} \text { for other areas. }\end{array}$ & $\begin{array}{l}25 \% \text { of workers complained of wheezing, no differences between the } \\
\text { subpopulations. }\end{array}$ \\
\hline $\begin{array}{l}\text { Dahlqvist et al. } \\
(1992)^{58}\end{array}$ & $\begin{array}{l}28 \text { wood trimmers, } 19 \\
\text { controls (office } \\
\text { workers) }\end{array}$ & $15-25 \mathrm{EU} / \mathrm{m}^{3}{ }^{*}$ & $\begin{array}{l}\text { Compared to the controls, wood trimmers had a significantly higher } \\
\text { prevalence of dry cough }(p=0.002) \text {, cough with phlegm ( } p=0.038) \text { and } \\
\text { breathlessness ( } p=0.020) \text {. }\end{array}$ \\
\hline $\begin{array}{l}\text { Sprince et al. } \\
(1997)^{59}\end{array}$ & $\begin{array}{l}183 \text { machine workers } \\
\text { in automobile }\end{array}$ & $\begin{array}{l}\mathrm{GM} 31 \mathrm{EU} / \mathrm{m}^{3} \text {, } \\
\text { range } 2.7-984\end{array}$ & $\begin{array}{l}\text { Symptoms reported significantly more often by subjects than by } \\
\text { controls were: cough (OR 3.1; } 95 \% \mathrm{Cl} 1.4-6.9 \text { ); phlegm (OR } 3.1 ; 95 \% \mathrm{Cl}\end{array}$ \\
\hline
\end{tabular}




\begin{tabular}{|c|c|c|c|}
\hline & $\begin{array}{l}\text { industry. } \\
66 \\
\text { assemblers(controls). }\end{array}$ & & $\begin{array}{l}\text { 1.6-6.1); work-related chest-tightness (OR 5.9; 95\% Cl 1.4-25.7); post- } \\
\text { shift chest tightness (OR } 4.5 ; 95 \% \mathrm{Cl} 1.3-15.2 \text { ) and post-shift cough (OR } \\
4.0 ; 95 \% \mathrm{Cl} 1.2-14.1 \text { ). }\end{array}$ \\
\hline $\begin{array}{l}\text { Zock et al. } \\
(1998)^{67}\end{array}$ & $\begin{array}{l}57 \text { potato processing } \\
\text { workers. }\end{array}$ & $\begin{array}{l}\text { AM } 32.9 \mathrm{EU} / \mathrm{m}^{3} \text {. } \\
\text { Low exposed group: AM } 21 \\
\text { EU/m } \mathrm{m}^{3} \text {, } \\
\text { high exposed group: } 56 \mathrm{EU} / \mathrm{m}^{3} \text {. }\end{array}$ & $\begin{array}{l}25 \% \text { of the exposed workers reported at least one of the work-related } \\
\text { respiratory symptoms (cough, phlegm, shortness of breath, chest } \\
\text { tightness). These seemed to be more prevalent among the low exposed } \\
\text { group. }\end{array}$ \\
\hline $\begin{array}{l}\text { Mandryk et } \\
\text { al.Mandryk et } \\
\text { al. (1999)68 }\end{array}$ & $\begin{array}{l}168 \text { wood workers. } 30 \\
\text { maintenance workers } \\
\text { (controls). }\end{array}$ & $\begin{array}{l}\text { Inhalable endotoxin: GM 24.1- } \\
43.0 \mathrm{EU} / \mathrm{m}^{3} \text { (GSD 15.5-47.7). } \\
\text { Respirable endotoxin: GM 3.3-6.5 } \\
\mathrm{EU} / \mathrm{m}^{3} \text { (GSD 13.5-41.0).* }\end{array}$ & $\begin{array}{l}\text { Regular cough and phlegm were significantly more prevalent in the } \\
\text { woodworkers when compared to controls, } 61 \% \text { vs } 23.5 \% \text { and } 61.5 \% \text { vs } \\
23.5 \%(p<0.001) \text {. Chronic bronchitis was also more prevalent in } \\
\text { woodworkers }(30.3 \%) \text { compared to controls }(11.8 \%)(p<0.05) \text {. }\end{array}$ \\
\hline $\begin{array}{l}\text { Wouters et al. } \\
(2002)^{69}\end{array}$ & $\begin{array}{l}47 \text { waste collecting } \\
\text { workers. } 15 \text { controls. }\end{array}$ & $\begin{array}{l}\mathrm{GM} 39.4 \mathrm{EU} / \mathrm{m}^{3} \\
\text { range } 4-7182\end{array}$ & $\begin{array}{l}\text { No significant difference in prevalence of respiratory symptoms among } \\
\text { exposed workers when compared to controls. }\end{array}$ \\
\hline $\begin{array}{l}\text { Fransman et al. } \\
(2003)^{70}\end{array}$ & $\begin{array}{l}112 \text { plywood mill } \\
\text { workers. } 415 \text { controls } \\
\text { of the general } \\
\text { population. }\end{array}$ & GM 23.0 EU/m³ (GSD 2.8) & $\begin{array}{l}\text { Significantly more attacks of shortness of breath with wheezing were } \\
\text { found in subjects, OR } 1.8(95 \% \mathrm{Cl} 1.0-3.1, \mathrm{p}<0.05) \text {. Almost all other } \\
\text { asthma symptoms were increased in the exposed group, but did not } \\
\text { reach significance. Shortness of breath with wheezing, waking by } \\
\text { shortness of breath and asthma were significantly more present in } \\
\text { workers employed }>6.5 \text { years (all } p<0.05) .53-83 \% \text { of respiratory } \\
\text { symptoms lessened during holidays. }\end{array}$ \\
\hline $\begin{array}{l}\text { Heldal et al. } \\
(2004)^{61}\end{array}$ & $\begin{array}{l}22 \text { waste collection } \\
\text { workers. }\end{array}$ & $\begin{array}{l}\text { AM } 2.5 \mathrm{EU} / \mathrm{m}^{3} \text {, } \\
\text { range } 0-7.8\end{array}$ & $\begin{array}{l}58 \% \text { of the workers reported any work-related symptom, } 41 \% \text { reported } \\
\text { any respiratory symptom, } 15 \% \text { reported cough. No statistically } \\
\text { significant difference in exposure level to endotoxin between subjects } \\
\text { with and without symptoms. }\end{array}$ \\
\hline
\end{tabular}




\begin{tabular}{|c|c|c|c|}
\hline $\begin{array}{l}\text { Kennedy et al. } \\
(2004)^{71}\end{array}$ & $\begin{array}{l}226 \text { glass bottle } \\
\text { recycling workers. } 212 \\
\text { ferry workers } \\
\text { (controls). }\end{array}$ & $\begin{array}{l}\mathrm{GM} 3.6-4.3 \mathrm{EU} / \mathrm{m}^{3}, \\
\text { range }<0.14-179\end{array}$ & $\begin{array}{l}\text { Attacks of chest tightness were significantly more prevalent in the } \\
\text { exposed groups than in the control group: } 22-41 \% \text { in subjects vs } 17 \% \text { in } \\
\text { controls (OR } 1.8,95 \% \mathrm{Cl} 1.1-3.3 \text { ). Chest tightness at work was also more } \\
\text { prevalent in the exposed groups than in the control group: } 5-15 \% \text { in } \\
\text { subjects vs } 2 \% \text { in controls (OR } 4.8,95 \% \mathrm{Cl} 1.1-21.5 \text { ). }\end{array}$ \\
\hline $\begin{array}{l}\text { Smit et al. } \\
(2005)^{72}\end{array}$ & $\begin{array}{l}371 \text { waste water } \\
\text { workers. } 97 \text { office } \\
\text { staff, } 2698 \text { general } \\
\text { population members } \\
\text { (controls). }\end{array}$ & GM $27 \mathrm{EU} / \mathrm{m}^{3}$ (GSD 3.7) & $\begin{array}{l}\text { Prevalence of daily cough (PR 1.48; } 95 \% \mathrm{Cl} 1.20-1.82 \text { ), shortness of } \\
\text { breath (PR 1.48; } 95 \% \mathrm{Cl} 1.04-2.09 \text { ) and asthma attacks (PR } 1.79 ; 95 \% \mathrm{Cl} \\
1.24-2.59) \text { were significantly higher among exposed subjects than in the } \\
\text { general population. Length of employment }>20 \text { years was significantly } \\
\text { associated with lower respiratory and skin symptoms (PR } 6.58 ; 95 \% \mathrm{Cl} \\
2.49-17.35 ; \mathrm{p}<0.001) \text {. }\end{array}$ \\
\hline $\begin{array}{l}\text { Widmeier et al. } \\
(2007)^{73}\end{array}$ & $\begin{array}{l}409 \text { wastewater-and } \\
\text { garbage workers. } 369 \\
\text { public transport and } \\
\text { forestry workers } \\
\text { (controls). }\end{array}$ & $\begin{array}{l}\text { Waste water workers: winter } 8.8- \\
29.7 \mathrm{EU} / \mathrm{m}^{3} \text {, summer } 29.8-52.6 \\
\mathrm{EU} / \mathrm{m}^{3} \text {; garbage collectors winter } \\
3.43-8.14 \mathrm{EU} / \mathrm{m}^{3} \text {, summer } 3.63- \\
11.03 \mathrm{EU} / \mathrm{m}^{3} \text {. }\end{array}$ & $\begin{array}{l}\text { Respiratory symptoms were not more prevalent in exposed subjects } \\
\text { when compared to controls. }\end{array}$ \\
\hline $\begin{array}{l}\text { Rusca et al. } \\
(2008)^{64}\end{array}$ & 111 sawmill workers & Range $1-24 \mathrm{EU} / \mathrm{m}^{3}$ & $\begin{array}{l}\text { No significant relationship between the medical complaints and the } \\
\text { concentrations of endotoxin or dust. }\end{array}$ \\
\hline $\begin{array}{l}\text { Dang et al. } \\
(2010)^{65}\end{array}$ & $\begin{array}{l}69 \text { water resort } \\
\text { workers, } 74 \text { office } \\
\text { workers(controls). }\end{array}$ & $\begin{array}{l}\text { Mean } 45 \mathrm{EU} / \mathrm{m}^{3} \text {, } \\
\text { range } 18-84\end{array}$ & $\begin{array}{l}\text { Exposed subjects had significantly more work-related symptoms than } \\
\text { unexposed: cough PR } 10.24 \text { ( } 95 \% \mathrm{Cl} 4.33-24.23) \text {, wheezing PR } 9.74 \text { ( } 95 \% \\
\mathrm{Cl} 2.36-40.19) \text {, shortness of breath PR } 6.70 \text { ( } 95 \% \mathrm{Cl} 2.47-18.20) \text {, chest } \\
\text { tightness PR } 6.67 \text { ( } 95 \% \mathrm{Cl} 2.08-21.35) \text {. Symptoms of cough were } \\
\text { significantly increased on high occupancy days (>1000 patrons) } \\
\text { compared with low occupancy days (<100 patrons), PR } 2.23 \text { (95\%Cl } \\
1.10-4.52) \text {. }\end{array}$ \\
\hline
\end{tabular}




\begin{tabular}{|c|c|c|c|}
\hline $\begin{array}{l}\text { Renström et al. } \\
(2011)^{74}\end{array}$ & 59 pet shop workers. & Range $1-100 \mathrm{EU} / \mathrm{m}^{3}$ & $\begin{array}{l}22 \% \text { reported wheezing or chest tightness. No significant difference in } \\
\text { exposure levels of endotoxin between subjects with work symptoms } \\
\text { compared to subjects without symptoms. }\end{array}$ \\
\hline $\begin{array}{l}\text { Schlunssen et } \\
\text { al. (2011) } 75\end{array}$ & $\begin{array}{l}232 \text { woodchip and } \\
\text { straw workers. } 107 \\
\text { oil/gas workers } \\
\text { (controls). }\end{array}$ & $\begin{array}{l}\text { Woodchip plants: median } 1.7 \\
\text { EU/m }{ }^{3} \text {, range } 0.01-6.5 . \\
\text { Straw plants: median } 74 \mathrm{EU} / \mathrm{m}^{3} \text {, } \\
\text { range } 1.5-294 . \\
\text { Control: median } 0.9 \mathrm{EU} / \mathrm{m}^{3}\end{array}$ & $\begin{array}{l}\text { Asthma symptoms were significantly more prevalent in straw workers } \\
\text { when compared to controls (OR } 7.6 ; 95 \% \mathrm{Cl} 1.4-40.4) \text {. }\end{array}$ \\
\hline $\begin{array}{l}\text { Meza et al. } \\
(2013)^{76}\end{array}$ & $\begin{array}{l}183 \text { aircraft workers } \\
\text { exposed to MWF. } 224 \\
\text { office workers } \\
\text { (controls). }\end{array}$ & $\begin{array}{l}\text { Mean } 1.2 \mathrm{EU} / \mathrm{m}^{3}, \\
\text { range } 0.42-2.7\end{array}$ & $\begin{array}{l}\text { Among the exposed workers, wheezing was significantly more present } \\
\text { when compared to the controls, PR } 1.54 \text { ( } 95 \% \mathrm{Cl} 1.03-2.29) \text {. Also, } \\
\text { decline in wheezing symptoms on vacation/days off was significantly } \\
\text { greater in the exposed group, PR } 2.84(95 \% \mathrm{Cl} 1.56-5.18) \text {. Exposed } \\
\text { workers woke significantly more often with a feeling of chest tightness } \\
\text { (PR } 2.4 ; 95 \% \mathrm{Cl} 1.30-4.69) \text { and this also improved significantly more on } \\
\text { vacation days when compared to controls (PR } 2.22 ; 95 \% \mathrm{Cl} 1.05-4.72) \text {. } \\
\text { Work related asthma symptoms were significantly more prevalent } \\
\text { among the exposed workers, PR } 1.92(95 \% \mathrm{Cl} 1.19-3.09) \text {. }\end{array}$ \\
\hline $\begin{array}{l}\text { Shiryaeva et al. } \\
(2014)^{77}\end{array}$ & $\begin{array}{l}70 \text { salmon processing } \\
\text { workers. }\end{array}$ & $\begin{array}{l}\text { Monday-Thursday GM } 1.39-1.65 \\
\mathrm{EU} / \mathrm{m}^{3} \text {, range } 0.30-29.0\end{array}$ & $\begin{array}{l}\text { The highest frequency of symptoms was seen on Mondays and } \\
\text { decreased gradually over the week. Wheeze and chest tightness } \\
\text { decreased significantly over the workweek }(p<0.05) \text {. }\end{array}$ \\
\hline $\begin{array}{l}\text { Heldal et al. } \\
(2015)^{66}\end{array}$ & $\begin{array}{l}47 \text { compost workers, } \\
37 \text { office controls }\end{array}$ & $\begin{array}{l}\text { AM } 4.0-38 \mathrm{EU} / \mathrm{m}^{3}, \\
\text { range } 0-730\end{array}$ & $\begin{array}{l}\text { Cough (OR } 4.3,95 \% \mathrm{Cl} 1.0-18.2 \text { ) and one or more work-related } \\
\text { symptoms (OR } 4.0,95 \% \mathrm{Cl} 1.1-14.7 \text { ) were significantly more prevalent in } \\
\text { the compost workers when compared to controls. }\end{array}$ \\
\hline
\end{tabular}

* original values were presented in article in $\mathrm{mg} / \mathrm{m}^{3}$ or $\mathrm{ng} / \mathrm{m}^{3}$ 


\section{Table 4.5. Overzicht van resultaten - longfunctie}

\begin{tabular}{|c|c|c|c|}
\hline \multicolumn{4}{|c|}{ Results Spirometry } \\
\hline \multicolumn{4}{|c|}{ Non-occupational populations } \\
\hline $\begin{array}{l}\text { Schiffman et al. } \\
(2005)^{78}\end{array}$ & 48 healthy subjects. & $7.40 \mathrm{EU} / \mathrm{m}^{3}$ & $\begin{array}{l}\text { No significant difference between change in lung function }\left(\mathrm{FEV}_{1}, \mathrm{FVC}\right. \\
\text { and FEF25-75\%) parameters after } 1 \text { hour exposure to } 7.40 \mathrm{EU} / \mathrm{m}^{3} \\
\text { airborne endotoxin when compared to control group }(\mathrm{p}>0.80) .\end{array}$ \\
\hline $\begin{array}{l}\text { Delfino et al. } \\
(2015)^{79}\end{array}$ & $\begin{array}{l}43 \text { asthmatic school- } \\
\text { children. }\end{array}$ & $\begin{array}{l}\text { Mean } 2.04 \mathrm{EU} / \mathrm{m}^{3}( \pm 3.71) \\
\text { range } 0.002-25.3\end{array}$ & $\begin{array}{l}\text { Subjects with low } \mathrm{FEV}_{1}(<80 \% \text { predicted) had a nominally significant } \\
\text { association with lag one }(\mathrm{p}<0.06) \text { and a significant association with } 2- \\
\text { day average endotoxin exposure }(\mathrm{p}<0.005) \text {. Subjects with low } \mathrm{FEV}_{1} \\
(<80 \% \text { predicted) experienced a significant } 7.7 \% \text { drop in \%predicted } \\
\mathrm{FEV}_{1}(95 \% \mathrm{Cl}-12.3 \% \text { to } \\
-3.3 \%) \text {, while those with higher } \mathrm{FEV} \mathrm{V}_{1} \text { values showed a non-significant } \\
0.5 \% \text { drop }(95 \% \mathrm{Cl}-2.2 \% \text { to } 1.2 \%) \text {. }\end{array}$ \\
\hline \multicolumn{4}{|c|}{ Occupational populations } \\
\hline $\begin{array}{l}\text { Kawamoto } \\
\text { et al. } \\
(1987)^{80}\end{array}$ & 128 cotton workers. & $\begin{array}{l}3 \text { groups: }<17 \mathrm{EU} / \mathrm{m}^{3}, 17-117 \\
\mathrm{EU} / \mathrm{m}^{3} \text { and }>117 \mathrm{EU} / \mathrm{m}^{3 *}\end{array}$ & $\begin{array}{l}13 \% \text { of subjects had }>5 \% \text { decrements in } \mathrm{FEV}_{1} \text { over the work shift. No } \\
\text { statistically significant differences in baseline lung functions between } \\
\text { workers employed for different lengths of time. }\end{array}$ \\
\hline
\end{tabular}




\begin{tabular}{|c|c|c|c|}
\hline $\begin{array}{l}\text { Kateman et } \\
\text { al. }(1990)^{57}\end{array}$ & $\begin{array}{l}40 \text { textile yarn } \\
\text { workers exposed to } \\
\text { spray-humidifier, } 42 \\
\text { controls exposed to } \\
\text { other or no } \\
\text { humidifier. }\end{array}$ & $\begin{array}{l}\mathrm{GM} 0.64 \mathrm{EU} / \mathrm{m}^{3} \text { (GSD 0.016) for } \\
\text { cold-water humidification area, } \\
0.18-0.19 \mathrm{EU} / \mathrm{m}^{3} \text { for other areas. }\end{array}$ & $\begin{array}{l}\text { In the workers of the cold-water department the mean change in } \\
\mathrm{FEV}_{1} \text { was }-0.096 \mathrm{~L} \text { (SD 0.159) on Day } 1,-0.065 \mathrm{~L} \text { (SD 0.134) on Day 2, - } \\
0.067 \mathrm{~L}(\mathrm{SD} 0.130 \text { ) on Day } 3 \text { (all p<0.01). FVC, MMEF, MEF25, MEF50 } \\
\text { and MEF75 also showed significant decline across the work shift and } \\
\text { over the week in this group. The lung function level on Friday was } \\
\text { reduced when compared to Monday. The other workers did not show } \\
\text { a significant decline in lung function. }\end{array}$ \\
\hline $\begin{array}{l}\text { Dahlqvist et } \\
\text { al. }(1992)^{58}\end{array}$ & $\begin{array}{l}28 \text { wood trimmers, } 19 \\
\text { controls (office } \\
\text { workers }\end{array}$ & $15-25 \mathrm{EU} / \mathrm{m}^{3}{ }^{*}$ & $\begin{array}{l}\text { There were no significant differences between the lung function } \\
\text { values in wood trimmers and controls. Wood trimmers sero-positive } \\
\text { for precipitating antibodies to moulds showed a significant decrease } \\
\text { in } \mathrm{FEV}_{1} \text { over a workweek. Subjects with a period of employment }>18 \\
\text { years had a significantly larger change in MEF over the workweek } \\
\text { than subjects employed }<6 \text { years. }\end{array}$ \\
\hline $\begin{array}{l}\text { Sprince et } \\
\text { al. }(1997)^{59}\end{array}$ & $\begin{array}{l}183 \text { machine workers } \\
\text { in automobile } \\
\text { industry. } 66 \\
\text { assemblers (controls). }\end{array}$ & $\begin{array}{l}\mathrm{GM} 31 \mathrm{EU} / \mathrm{m}^{3}, \\
\text { range } 2.7-984\end{array}$ & $\begin{array}{l}\text { Pre-shift \%predicted } \mathrm{FEV}_{1} \text { and } \mathrm{FVC} \text { did not differ significantly. } \\
\text { Machine operators did not significantly differ from controls in } \\
\text { proportion who decreased }>5 \% \text { for } \mathrm{FEV}_{1}(16 \% \text { vs } 12 \%, \mathrm{p}=0.42) \text { or } \mathrm{FVC} \\
(14 \% \text { vs } 9 \%, \mathrm{p}=0.33) \text {. }\end{array}$ \\
\hline $\begin{array}{l}\text { Zock et al. } \\
(1998)^{67}\end{array}$ & $\begin{array}{l}57 \text { potato processing } \\
\text { workers. }\end{array}$ & $\begin{array}{l}\text { AM } 32.9 \mathrm{EU} / \mathrm{m}^{3} \\
\text { Low exposed group: AM } 21 \\
\mathrm{EU} / \mathrm{m}^{3} \text {, high exposed group: } 56 \\
\mathrm{EU} / \mathrm{m}^{3} \text {. }\end{array}$ & $\begin{array}{l}\text { Baseline lung function seemed to be lower in the high exposed group, } \\
\text { although this did not reach statistical significance. Mean } \mathrm{FEV}_{1} \text { and } \\
\text { MMEF showed a significant decrease across each shift. Mean } \\
\text { absolute decrease in } \mathrm{FEV}_{1} \text { was } 0.06-0.12 \mathrm{~L} \text {, mean absolute decrease in } \\
\mathrm{FVC} \text { was } 0.16-0.28 \mathrm{~L} / \mathrm{sec} \text { (both } \mathrm{p}<0.01 \text { ). }\end{array}$ \\
\hline $\begin{array}{l}\text { Mandryk et } \\
\text { al. }(1999)^{81}\end{array}$ & $\begin{array}{l}168 \text { wood workers. } 30 \\
\text { maintenance workers } \\
\text { (controls). }\end{array}$ & $\begin{array}{l}\text { Inhalable endotoxin: GM 24.1- } \\
43.0 \mathrm{EU} / \mathrm{m}^{3} \text { (GSD 15.5-47.7). } \\
\text { Respirable endotoxin: GM 3.3-6.5 } \\
\text { EU } / \mathrm{m}^{3} \text { (GSD 13.5-41.0).* }\end{array}$ & $\begin{array}{l}\text { Woodworkers had significantly lower predicted lung functions than } \\
\text { controls. VC } 83.45 \pm 3.12 \text { vs } 95.35 \pm 7.93 \text { ( } p=0.0001) \text {, FVC } 84.66 \pm 0.72 \\
\text { vs } 94.90 \pm 3.85 \text { ( } p=0.0001), F^{\prime} V_{1} 84.67 \pm 1.20 \text { vs } 93.11 \pm 2.81 \\
\text { ( } p=0.0001) \text {. The cross-shift decrease in lung function was significant }\end{array}$ \\
\hline
\end{tabular}




\begin{tabular}{|c|c|c|c|}
\hline & & & $\begin{array}{l}\text { for all lung function parameters ( } p<0.001 \text { ) in woodworkers compared } \\
\text { with controls (VC } 6.32 \% \text { vs } 2.37 \% \text { decrease; FVC } 4.40 \% \text { vs } 2.12 \% \\
\text { decrease; FEV } 16.34 \% \text { vs } 1.78 \% \text { decrease; FEV } 1 \text { FVC } 2.86 \% \text { vs } 0.06 \% \\
\text { decrease; FEF } 25-75 \% 7.74 \% \text { vs } 2.22 \% \text { decrease; PEF } 6.62 \% \text { vs } 5.20 \% \\
\text { decrease). Percentage predicted lung function was positively } \\
\text { correlated with the number of years exposed to wood dust. }\end{array}$ \\
\hline $\begin{array}{l}\text { Mahar et al. } \\
(2002)^{60}\end{array}$ & $\begin{array}{l}87 \text { refuse derived fuel } \\
\text { workers. }\end{array}$ & $\begin{array}{l}\text { 1995: GM 28.5 EU/m³ (GSD 2.77). } \\
2000 \mathrm{GM} 28.1 \mathrm{EU} / \mathrm{m}^{3} \text { (GSD 6.65). } \\
\text { Total GM 28.4 EU/m³ (GSD 3.75). }\end{array}$ & $\begin{array}{l}\text { No significant changes in lung function over the period of } 1995-2000 \\
\text { in exposed workers. } \Delta \mathrm{FVC} 1995-2000 \text { : mean }-0.76 \text { (SD 11.9); } \mathrm{p}=0.33 \text {. } \\
\Delta \mathrm{FEV}_{1} \text { mean }-1.31(\mathrm{SD} 12.5) ; \mathrm{p}=0.76 \text {. No significant differences } \\
\text { between workers employed less than } 10 \text { years and workers employed } \\
\text { more than } 10 \text { years in decrease in lung function. }\end{array}$ \\
\hline $\begin{array}{l}\text { Sigsgaard et al. } \\
(2004)^{62}\end{array}$ & $\begin{array}{l}97 \text { paper mill workers. } \\
55 \text { water-supply } \\
\text { workers (controls). }\end{array}$ & $\begin{array}{l}6-69 \mathrm{EU} / \mathrm{m}^{3} \text {, } \\
\text { range 6-370. } 3 \text { groups: low, } \\
\text { medium and high exposed. }\end{array}$ & $\begin{array}{l}\text { Loss of lung function in } \mathrm{ml} / \text { year did not differ significantly among the } \\
\text { groups, ranging from }-36.62 \mathrm{ml} / \text { year to }-54.09 \mathrm{ml} / \text { year for } \mathrm{FEV}_{1} \text {. }\end{array}$ \\
\hline $\begin{array}{l}\text { Widmeier et } \\
\text { al. }(2007)^{73}\end{array}$ & $\begin{array}{l}409 \text { wastewater-and } \\
\text { garbage workers. } 369 \\
\text { public transport and } \\
\text { forestry workers } \\
\text { (controls). }\end{array}$ & $\begin{array}{l}\text { Waste water workers: winter } 8.8- \\
29.7 \mathrm{EU} / \mathrm{m}^{3} \text {, summer } 29.8-52.6 \\
\mathrm{EU} / \mathrm{m}^{3} \text {; garbage collectors winter } \\
3.43-8.14 \mathrm{EU} / \mathrm{m}^{3} \text {, summer } 3.63- \\
11.03 \mathrm{EU} / \mathrm{m}^{3} \text {. }\end{array}$ & $\begin{array}{l}\text { A statistically significant difference in } \mathrm{FEV}_{1} \text { and } \mathrm{FVC} \text { among garbage } \\
\text { collectors when compared to the other groups was seen only in } \\
\text { current smokers and disappeared after considering smoking in the } \\
\text { model. }\end{array}$ \\
\hline $\begin{array}{l}\text { Rusca et al. } \\
(2008)^{64}\end{array}$ & 111 sawmill workers. & Range $1-24 \mathrm{EU} / \mathrm{m}^{3}$ & $\begin{array}{l}\text { Lung function tests were not significantly associated with exposure to } \\
\text { bioaerosols. }\end{array}$ \\
\hline $\begin{array}{l}\text { Renström et } \\
\text { al. (2011) }\end{array}$ & 59 pet shop workers. & Range $1-100 \mathrm{EU} / \mathrm{m}^{3}$ & $\begin{array}{l}\text { Lung function values were on average slightly lower than expected } \\
\text { among the exposed: } 91.4 \% \text { (SD 10.9) for VC, } 93.3 \% \text { (SD 11.1) FVC, } \\
94.8 \% \text { (SD 13.3) for } F E V_{1} .\end{array}$ \\
\hline
\end{tabular}




\begin{tabular}{|c|c|c|c|}
\hline $\begin{array}{l}\text { Shiryaeva et } \\
\text { al. (2014) }{ }^{77}\end{array}$ & $\begin{array}{l}70 \text { salmon processing } \\
\text { workers. }\end{array}$ & $\begin{array}{l}\text { Monday-Thursday GM 1.39-1.65 } \\
\mathrm{EU} / \mathrm{m}^{3} \text {, range } 0.30-29.0\end{array}$ & $\begin{array}{l}\text { Significant decline in cross-shift \% } \mathrm{FEV}_{1} \text { was seen on Monday with a } \\
\text { mean decrease of } 0.41-0.93 \% \mathrm{FEV}_{1}(\mathrm{SD} 5.24-7.52)(\mathrm{p}<0.05) \text {. Analysis } \\
\text { of cross-week change in } \mathrm{FEV}_{1} \text { did not show significant change. }\end{array}$ \\
\hline $\begin{array}{l}\text { Cyprowski } \\
\text { et al. } \\
(2015)^{82}\end{array}$ & 78 sewage workers. & $\begin{array}{l}\mathrm{AM} 38.8 \mathrm{EU} / \mathrm{m}^{3} \\
\text { range } 0.63-214\end{array}$ & $\begin{array}{l}\text { Mean values of } \mathrm{FEV}_{1} \text { and } \mathrm{FVC} \text { declined during work shift; FVC } 4.64 \text { vs } \\
4.60, \mathrm{FEV}_{1} 4.00 \text { vs } 3.98 \text { (I). }\end{array}$ \\
\hline $\begin{array}{l}\text { Heldal et al. } \\
(2015)^{66}\end{array}$ & $\begin{array}{l}47 \text { compost workers, } \\
37 \text { office controls }\end{array}$ & $\begin{array}{l}\mathrm{AM} 4.0-38 \mathrm{EU} / \mathrm{m}^{3}, \\
\text { range } 0-730\end{array}$ & $\begin{array}{l}\text { Predicted FVC\% measured before work was significantly lower in the } \\
\text { compost workers as compared to controls }(p<0.05) \text {. Cross-shift } \\
\text { changes in lung function parameters were not significantly different } \\
\text { between subjects and controls. }\end{array}$ \\
\hline $\begin{array}{l}\text { Ghani et al. } \\
(2016)^{83}\end{array}$ & $\begin{array}{l}100 \text { textile mill } \\
\text { workers, } 100 \text { controls. }\end{array}$ & Range $40-300 \mathrm{EU} / \mathrm{m}^{3}$ & $\begin{array}{l}\text { The mean values of } F V C, \mathrm{FEV}_{1}, \mathrm{FEV} / \mathrm{FVC} \text { and } \mathrm{PEF} \text { were significantly } \\
\text { reduced in the exposed subjects of all age groups compared to a } \\
\text { control group }(p<0.05) \text {. This effect is highly significant in the age } \\
\text { group 30-40 years }(p<0.001)\end{array}$ \\
\hline
\end{tabular}

* original values were presented in article in $\mathrm{mg} / \mathrm{m}^{3}$ or $\mathrm{ng} / \mathrm{m}^{3}$ 
Tabel A4.6. Overzicht van resultaten - exposure-response relaties endotoxine

\begin{tabular}{|c|c|c|c|}
\hline \multicolumn{4}{|c|}{ Results Exposure-response analysis } \\
\hline $\begin{array}{l}\text { Author } \\
\text { (year) }\end{array}$ & Population & $\begin{array}{l}\text { Levels of airborne } \\
\text { endotoxin exposure } \\
\left(\mathrm{EU} / \mathrm{m}^{3}\right)\end{array}$ & Dose-dependent effects \\
\hline \multicolumn{4}{|c|}{ Non-occupational populations } \\
\hline $\begin{array}{l}\text { Rabinovitch } \\
\text { et al. } \\
(2005)^{63}\end{array}$ & $\begin{array}{l}24 \text { asthmatic } \\
\text { school- } \\
\text { children }\end{array}$ & $\begin{array}{l}\text { Interval 1: median } 0.08 \\
\text { EU/m³ }{ }^{3} \text {, IQR } 0.09 \\
\text { Interval 2: median } 0.37 \\
\text { EU } / \mathrm{m}^{3} \text {, IQR } 0.16\end{array}$ & $\begin{array}{l}\text { Evening } \mathrm{FEV}_{1} \text { levels were significantly lower when children were exposed to higher } \\
\text { personal levels of endotoxin, }-316 \mathrm{ml}(95 \% \mathrm{Cl}-597 \text { to }-36 ; \mathrm{p}=0.036) \text { per } 1 \mathrm{EU} / \mathrm{m}^{3} \\
\text { increase in personal endotoxin exposure. } \\
\text { For every increase of } 1 \mathrm{EU} / \mathrm{m}^{3} \text { endotoxin exposure, the OR for sleep-related } \\
\text { asthma symptoms was } \mathbf{2 . 0 4 2}(\mathbf{9 5 \% \mathrm { Cl }} \mathbf{1 . 0 2 9 - 4 . 0 4 2 ;} \mathrm{p}=\mathbf{0 . 0 4 1 )} \text {. }\end{array}$ \\
\hline $\begin{array}{l}\text { Hoopmann } \\
\text { et al. } \\
(2006)^{2584}\end{array}$ & 3867 children & $\begin{array}{l}\text { Median } 0.064 \mathrm{EU} / \mathrm{m}^{3}, \mathrm{IQR} \\
0.025-0.141^{*}\end{array}$ & $\begin{array}{l}\text { Per one unit log increase in endotoxin exposure the OR for asthmatic symptoms } \\
\text { among children with atopic parents was } 1.15(95 \% \mathrm{Cl} \mathbf{1 . 0 3 - 1 . 2 9 , p = 0 . 0 1 5 6 ) . ~ F o r ~} \\
\text { children of non-atopic parents, the OR was } 0.95(95 \% \mathrm{Cl} 0.88-1.05) \text {. For children } \\
\text { with atopic parents, wheezing had an OR of } 1.15(95 \% \mathrm{Cl} \mathbf{1 . 0 4 - 1 . 2 7 )} \text { per one unit } \\
\text { increase of log endotoxin. }\end{array}$ \\
\hline $\begin{array}{l}\text { Horick et al. } \\
(2006)^{26}\end{array}$ & 360 children & $\begin{array}{l}\text { Mean } 0.81 \mathrm{EU} / \mathrm{m}^{3}, \\
\text { range } 0.23-5.87\end{array}$ & $\begin{array}{l}\text { An increase of } 0.39 \log _{10}\left(\mathrm{EU} / \mathrm{m}^{3}\right) \text { in airborne endotoxin exposure resulted in a } \\
\text { significant increase in prevalence of wheeze, with a relative risk of } 5.56(95 \% \mathrm{Cl} \\
\text { 1.19-26.03). }\end{array}$ \\
\hline $\begin{array}{l}\text { Ramagopal } \\
\text { et al. } \\
(2014)^{85}\end{array}$ & 75 children & $\begin{array}{l}\text { SIM: median } 0.6 \mathrm{EU} / \mathrm{m}^{3} \\
\text { range } 0.03-8.6 \\
\text { PIPER: median } 1.0 \\
\mathrm{EU} / \mathrm{m}^{3} \text {, range } 0.09-16\end{array}$ & $\begin{array}{l}\text { The OR for wheeze for children exposed to } 0.57-1.03 \mathrm{EU} / \mathrm{m}^{3} \text { was } 3.0(95 \% \mathrm{Cl} 0.6- \\
14.8) \text { when compared to children exposed to lower levels of endotoxin when } \\
\text { measured with PIPER; for SIM, this OR was } 1.3(0.3-6.1) \text {. For asthma, the OR }\end{array}$ \\
\hline
\end{tabular}




\begin{tabular}{|c|c|c|c|}
\hline & & & $\begin{array}{l}\text { children exposed to } 0.57-1.03 \mathrm{EU} / \mathrm{m}^{3} \text { was } 2.6(95 \% \mathrm{Cl} 0.6-11.3) \text { when measured } \\
\text { with PIPER and } 1.5(95 \% \mathrm{Cl} 0.4-6.0) \text { when measured with SIM. }\end{array}$ \\
\hline $\begin{array}{l}\text { Delfino et } \\
\text { al. (2015) } 79\end{array}$ & $\begin{array}{l}43 \text { asthmatic } \\
\text { school- } \\
\text { children }\end{array}$ & $\begin{array}{l}\text { Mean } 2.04 \mathrm{EU} / \mathrm{m}^{3} \\
( \pm 3.71) \\
\text { range } 0.002-25.3\end{array}$ & $\begin{array}{l}\text { An increase of } 2.19 \mathrm{EU} / \mathrm{m}^{3} \text { resulted in a significant } 7.7 \%(95 \% \mathrm{Cl}-12.3 \text { to }-3) \text { drop in } \\
\% \text { predicted } \mathrm{FEV}_{1} \text { in patients with a baseline \%predicted } \mathrm{FEV}_{1}<80 \% \text {. }\end{array}$ \\
\hline $\begin{array}{l}\text { Lai et al. } \\
(2015)^{86}\end{array}$ & $\begin{array}{l}248 \text { asthmatic } \\
\text { school- } \\
\text { children }\end{array}$ & $\begin{array}{l}\mathrm{GM} 24.7 \mathrm{EU} / \mathrm{m}^{3} \text {, } \\
\text { range } 0.2-780.0 \\
\text { (of which } 78 \%<90 \\
\mathrm{EU} / \mathrm{m}^{3} \text { ) }\end{array}$ & $\begin{array}{l}\text { An increase in airborne endotoxin from } 0.2 \mathrm{EU} / \mathrm{m}^{3} \text { to } 24.7 \mathrm{EU} / \mathrm{m}^{3} \text { was associated } \\
\text { with a dose-dependent increase in maximum asthma symptoms days for children } \\
\text { with non-atopic asthma, adjusted IRR } 1.16 \text { ( } 95 \% \mathrm{Cl} 1.03-1.31) \text {; atopic asthma } 1.00 \\
\text { (0.93-1.07). Maximum asthma symptoms days increased with } 1.3 \text { days for each } 14- \\
\text { day period. Daytime wheeze and exercise-related symptoms significantly } \\
\text { increased when exposure levels increased from } 0.2 \mathrm{EU} / \mathrm{m}^{3} \text { to } 24.7 \mathrm{EU} / \mathrm{m}^{3} \text {; IRR } 1.21 \\
(95 \% \mathrm{Cl} 1.06-1.38) \text { and IRR } 1.45(1.19-1.77) \text { respectively. }\end{array}$ \\
\hline $\begin{array}{l}\text { Bose et al. } \\
(2016)^{87}\end{array}$ & $\begin{array}{l}84 \text { COPD } \\
\text { patients }\end{array}$ & Mean $0.55 \mathrm{EU} / \mathrm{m}^{3}( \pm 1.3)$ & $\begin{array}{l}\text { Per } 1 \text { unit increase in } \log _{10} \text { airborne endotoxin, the OR for nocturnal symptoms was } \\
1.06(95 \% \mathrm{Cl} 0.74-1.52 ; \mathrm{p}=0.74) \text { and the OR for severe exacerbations was } 0.66 \\
(95 \% \mathrm{Cl} 0.35-1.25 ; p=0.20) \text {. }\end{array}$ \\
\hline \multicolumn{4}{|c|}{ Occupational populations } \\
\hline $\begin{array}{l}\text { Kawamoto } \\
\text { et al. } \\
(1987)^{80}\end{array}$ & $\begin{array}{l}128 \text { cotton } \\
\text { workers. }\end{array}$ & $\begin{array}{l}3 \text { groups: }<17 \mathrm{EU} / \mathrm{m}^{3}, 17- \\
117 \mathrm{EU} / \mathrm{m}^{3} \text { and }>117 \\
\mathrm{EU} / \mathrm{m}^{3 *}\end{array}$ & $\begin{array}{l}\text { The mean percentage change in } \mathrm{FEV}_{1} \text { over the work shift was }-1.09 \text { for the group } \\
\text { exposed to } 17-117 \mathrm{EU} / \mathrm{m}^{3} \text { and }-1.27 \text { for the group exposed to more than } 117 \\
\mathrm{EU} / \mathrm{m}^{3} \text {, these decreases did not reach statistical significance. }\end{array}$ \\
\hline $\begin{array}{l}\text { Sprince et } \\
\text { al. }(1997)^{59}\end{array}$ & $\begin{array}{l}183 \text { machine } \\
\text { workers. } 66 \\
\text { controls. }\end{array}$ & $\begin{array}{l}\mathrm{GM} 31 \mathrm{EU} / \mathrm{m}^{3}, \\
\text { range } 2.7-984\end{array}$ & $\begin{array}{l}\text { Usual phlegm showed a significant association with a one log increase in } \\
\text { endotoxin exposure, OR } 1.24 \text { ( } 95 \% \mathrm{Cl} 1.04-1.47) \text {. }\end{array}$ \\
\hline
\end{tabular}




\begin{tabular}{|c|c|c|c|}
\hline $\begin{array}{l}\text { Zock et al. } \\
(1998)^{67}\end{array}$ & $\begin{array}{l}57 \text { potato } \\
\text { processing } \\
\text { workers. }\end{array}$ & $\begin{array}{l}\text { AM } 32.9 \mathrm{EU} / \mathrm{m}^{3} \text {. } \\
\text { Low exposed group: AM } \\
21 \mathrm{EU} / \mathrm{m}^{3} \text {, high exposed } \\
\text { group: } 56 \mathrm{EU} / \mathrm{m}^{3} \text {. }\end{array}$ & $\begin{array}{l}\text { Across-shift decrease in } \mathrm{FEV}_{1}, \mathrm{FVC} \text { and MMEF was significantly larger }(p<0.01) \text { in } \\
\text { the high exposed group than in the low exposed group. }\end{array}$ \\
\hline $\begin{array}{l}\text { Mandryk et } \\
\text { al. (1999) })^{81}\end{array}$ & $\begin{array}{l}168 \text { wood } \\
\text { workers. } 30 \\
\text { maintenance } \\
\text { workers } \\
\text { (controls). }\end{array}$ & $\begin{array}{l}\text { Inhalable endotoxin: GM } \\
\text { 24.1-43.0 EU/m³ }(\mathrm{GSD} \\
\text { 15.5-47.7).* }\end{array}$ & $\begin{array}{l}\text { Per increase in one log unit of endotoxin exposure, } \mathrm{FEV}_{1} \text { decreased with } \mathbf{0 . 3 3} \\
(\mathbf{p}<0.001) \text {, FVC with } \mathbf{0 . 3 0}(\mathbf{p}<0.001) \text {. Per increase in one unit of endotoxin } \\
\text { exposure, the cross-shift change in VC was }-\mathbf{0 . 3 2}(\mathbf{p}<\mathbf{0 . 0 0 1 )} \text {. }\end{array}$ \\
\hline $\begin{array}{l}\text { Kennedy et } \\
\text { al. }(2004)^{71}\end{array}$ & $\begin{array}{l}226 \text { glass } \\
\text { bottle } \\
\text { recycling } \\
\text { workers. } 212 \\
\text { ferry workers } \\
\text { (controls). }\end{array}$ & $\begin{array}{l}\mathrm{GM} 3.6-4.3 \mathrm{EU} / \mathrm{m}^{3}, \\
\text { range }<0.14-179\end{array}$ & $\begin{array}{l}\text { There were no significant increases found in upper airway symptoms (OR } 1.6 \text {, } \\
95 \% \mathrm{Cl} 0.7-3.2 \text { ), chest symptoms (OR } 1.5,95 \% \mathrm{Cl} 0.6-4.7 \text { ) or somatic symptoms (OR } \\
1.6,95 \% \mathrm{Cl} 0.6-4.4 \text { ) when related to personal endotoxin exposure }>4 \mathrm{EU} / \mathrm{m}^{3} \mathrm{vs}<4 \\
\mathrm{EU} / \mathrm{m}^{3} \text {. }\end{array}$ \\
\hline $\begin{array}{l}\text { Sigsgaard et al. } \\
(2004)^{62}\end{array}$ & $\begin{array}{l}97 \text { paper mill } \\
\text { workers. } 55 \\
\text { water-supply } \\
\text { workers } \\
\text { (controls). }\end{array}$ & $\begin{array}{l}\text { 6-69 } \mathrm{EU} / \mathrm{m}^{3} \text {, } \\
\text { range 6-370. } 3 \text { groups: } \\
\text { low, medium and high } \\
\text { exposed. }\end{array}$ & $\begin{array}{l}\text { Exposure to endotoxin was negatively associated with FVC decline, significantly so } \\
\text { for the highest exposed group of paper workers with B } 23.4 \text { ( } 95 \% \text { CI 5.9-41.0, } \\
p=0.009) \text {. }\end{array}$ \\
\hline $\begin{array}{l}\text { Smit et al. } \\
(2005)^{72}\end{array}$ & $\begin{array}{l}371 \text { waste } \\
\text { water } \\
\text { workers. } 97 \\
\text { office staff, } \\
2698 \text { general }\end{array}$ & $\begin{array}{l}\text { GM } 27 \mathrm{EU} / \mathrm{m}^{3}(\mathrm{GSD} 3.7) \\
3 \text { groups: }<50,>50-200 \\
>200 \mathrm{EU} / \mathrm{m}^{3}\end{array}$ & $\begin{array}{l}\text { No statistically significant increase in respiratory symptoms with increasing levels } \\
\text { of exposure. }\end{array}$ \\
\hline
\end{tabular}




\begin{tabular}{|c|c|c|c|}
\hline & $\begin{array}{l}\text { population } \\
\text { (controls). }\end{array}$ & & \\
\hline $\begin{array}{l}\text { Schlunssen } \\
\text { et al. } \\
(2011)^{75}\end{array}$ & $\begin{array}{l}232 \text { woodchip } \\
\text { and straw } \\
\text { workers. } 107 \\
\text { workers in } \\
\text { oil/gas power } \\
\text { plants } \\
\text { (controls). }\end{array}$ & $\begin{array}{l}\text { Woodchip plants: median } \\
1.7 \mathrm{EU} / \mathrm{m}^{3} \text {, range } 0.01- \\
6.5 \\
\text { Straw plants: median } 74 \\
\mathrm{EU} / \mathrm{m}^{3} \text {, range } 1.5-294 . \\
\text { Control: median } 0.9 \\
\mathrm{EU} / \mathrm{m}^{3}\end{array}$ & $\begin{array}{l}\text { Increased asthma symptoms were significantly associated with exposure to } \\
\text { endotoxin in the most exposed group }\left(12.6-294 \mathrm{EU} / \mathrm{m}^{3}\right) \text {; adjusted OR } 8.1 \text { (1.5- } \\
\text { 44.4). In the least and moderate exposed group, this association was not } \\
\text { significant; adjusted OR } 2.6(0.3-20.0) \text { for least exposed and } 2.9(0.5-18.7) \text { for the } \\
\text { moderate exposed group. No significant relationship was found between level of } \\
\text { exposure to endotoxin and lung function parameters. }\end{array}$ \\
\hline $\begin{array}{l}\text { Shiryaeva et } \\
\text { al. (2014) }{ }^{77}\end{array}$ & $\begin{array}{l}70 \text { salmon } \\
\text { processing } \\
\text { workers }\end{array}$ & $\begin{array}{l}\text { Monday-Thursday GM } \\
1.39-1.65 \mathrm{EU} / \mathrm{m}^{3} \text {, range } \\
0.30-29.0\end{array}$ & $\begin{array}{l}\text { Multiple logistic regression showed non-significant increases in prevalence of } \\
\text { cough, OR } 1.07(95 \% \mathrm{Cl} 0.7-2.04) \text {; wheezing OR } 1.06(95 \% \mathrm{Cl} 0.02-7.63) \text { and chest } \\
\text { tightness, OR } 1.03(95 \% \mathrm{Cl} 0.20-4.36) \text { when exposure of endotoxin increased. } \\
\text { Change in } \mathrm{FEV}_{1} \text { in relation to increase in endotoxin exposure was also not } \\
\text { statistically significant. }\end{array}$ \\
\hline $\begin{array}{l}\text { Cyprowski } \\
\text { et } \\
\text { al.(2015) } 82\end{array}$ & $\begin{array}{l}78 \text { sewage } \\
\text { workers. }\end{array}$ & $\begin{array}{l}\mathrm{AM} 38.8 \mathrm{EU} / \mathrm{m}^{3}, \\
\text { range } 0.63-214\end{array}$ & $\begin{array}{l}\text { A significant impact on the across shift decline in } \mathrm{FEV}_{1} \text { was found in the multifactor } \\
\text { model; linear regression showed a decrease of } 0.042 \mathrm{~L} \text { in } \mathrm{FEV}_{1}(\mathrm{p}=0.044) \text {. }\end{array}$ \\
\hline $\begin{array}{l}\text { Heldal et al. } \\
\text { (2015) }\end{array}$ & $\begin{array}{l}47 \text { compost } \\
\text { workers, } 37 \\
\text { office controls }\end{array}$ & $\begin{array}{l}\text { AM 4.0-38 EU/m }{ }^{3} \text {, range } \\
0-730\end{array}$ & $\begin{array}{l}\text { Subjects exposed to } 0.7-2.7 \mathrm{EU} / \mathrm{m}^{3} \text { endotoxin had a significant } \mathrm{OR} \text { of } 4.7(95 \% \mathrm{Cl} \\
1.2-19) \text { for cough symptoms, as compared to non-exposed controls. For subjects } \\
\text { exposed to } 2.9-310 \mathrm{EU} / \mathrm{m}^{3} \text {, the OR for cough was } 3.4(95 \% \mathrm{Cl} 0.9-13) \text {. }\end{array}$ \\
\hline
\end{tabular}

* original values were presented in article in $\mathrm{mg} / \mathrm{m}^{3}$ or $\mathrm{ng} / \mathrm{m}^{3}$ 
Tabel A4.6 Analyse van effecten van endotoxine blootstelling in specifieke subgroepen

\begin{tabular}{|c|c|c|}
\hline \multicolumn{3}{|l|}{ Subgroup analyses } \\
\hline \multicolumn{3}{|l|}{ Smoking } \\
\hline Author (year) & Distribution of smokers* & Effect of smoking \\
\hline $\begin{array}{l}\text { Dahlquist et al. } \\
(1992)^{58}\end{array}$ & $\begin{array}{l}18 \% \text { ex-smokers, } 75 \% \text { non-smokers, } 7 \% \\
\text { smokers }\end{array}$ & $\begin{array}{l}\text { No differences in the distribution of symptoms between smokers and } \\
\text { non-smokers. }\end{array}$ \\
\hline Zock et al. (1998) ${ }^{67}$ & smokers 55-57\%, ex-smokers $22-25 \%$. & $\begin{array}{l}\text { Non-smokers showed larger across shift declines than smokers, for } \\
\mathrm{FEV}_{1} \text { the across shift difference was }-0.1 \%(95 \% \mathrm{Cl}-3.6 ; 3.5) \text { for } \\
\text { smokers and }-1.8 \%(95 \% \mathrm{Cl}-4.5 ; 1.0) \text { for non-smokers. }\end{array}$ \\
\hline Mahar et al. $(2002)^{60}$ & $\begin{array}{l}\text { 34-43\% smokers, } 57-66 \% \text { ex- and non- } \\
\text { smokers }\end{array}$ & $\begin{array}{l}\text { Smokers showed an across shift decline of } 1.12 \% \text { (SD 9.5) for FVC and } \\
2.26 \% \text { (SD 12.1) for FEV } 1 . \text { Non-smokers showed an across shift } \\
\text { decline of } 0.53 \% \text { (SD 11.9) for FVC and } 0.73 \% \text { (SD 12.5) for FEV } 1 \text {. }\end{array}$ \\
\hline $\begin{array}{l}\text { Sigsgaard et al. } \\
(2004)^{62}\end{array}$ & S: $26 \%, C: 58 \%$ & $\begin{array}{l}\text { The lung function decline was comparable among smokers and non- } \\
\text { smokers. }\end{array}$ \\
\hline $\begin{array}{l}\text { Widmeier et al. } \\
(2007)^{73}\end{array}$ & $\begin{array}{l}\text { Waste water: } 39 \% \text { smokers, } 29 \% \text { ex- } \\
\text { smokers, } 32 \% \text { never smokers. Garbage } \\
\text { workers: } 48 \% \text { smoker, } 31 \% \text { ex-smoker, } 21 \% \\
\text { never smoker. } \\
\text { C: } 34 \% \text { current smokers, } 23 \% \text { ex smokers, } \\
43 \% \text { never smokers. }\end{array}$ & $\begin{array}{l}\text { Exposed smoking garbage workers had significantly lower lung } \\
\text { function values than non-exposed smokers. For ex-smokers, no } \\
\text { significant difference was found according to exposure. }\end{array}$ \\
\hline
\end{tabular}




\begin{tabular}{|c|c|c|c|c|}
\hline $\begin{array}{l}\text { Schlunssen et al. } \\
\text { (2011) }\end{array}$ & \multicolumn{3}{|c|}{$28.7-39.9 \%$ in subjects, $31.8 \%$ in controls. } & $\begin{array}{l}\text { Asthma symptoms were associated with endotoxin in non-smokers } \\
\text { (OR10.1;1.7-59.7), whereas this was not found for smokers (OR 0.5; } \\
0.1-2.8 \text { ) }\end{array}$ \\
\hline $\begin{array}{l}\text { Shiryaeva et al. } \\
(2014)^{77}\end{array}$ & \multicolumn{3}{|c|}{$\begin{array}{l}37.1 \% \text { smokers, } 32.9 \% \text { ex-smokers, } 30 \% \\
\text { never smokers }\end{array}$} & $\begin{array}{l}\text { For smokers, mean cross shift decline in } \mathrm{FEV}_{1} \text { was } 0.93 \% \text { (SD 5.24), } \\
\text { this was } 0.72 \% \text { (SD 6.31) for former smokers and } 0.41 \% \text { (SD7.52) for } \\
\text { non-smokers. }\end{array}$ \\
\hline \multicolumn{5}{|c|}{ Atopics/asthmatics } \\
\hline Author (year) & Atopics & Asthma/COPD & \multicolumn{2}{|c|}{ Effect of atopy/asthma } \\
\hline $\begin{array}{l}\text { Hoopmann et al. } \\
(2006)^{2584}\end{array}$ & $\begin{array}{l}19.2 \% \text { boys, } \\
14.1 \% \text { girls }\end{array}$ & $\begin{array}{l}10.9 \% \text { boys, } 14.9 \% \\
\text { girls }\end{array}$ & \multicolumn{2}{|c|}{$\begin{array}{l}\text { Increase of asthmatic symptoms and wheezing due to exposure to airborne } \\
\text { endotoxin was significant for children of atopic parents, but not for children of } \\
\text { non-atopic parents. }\end{array}$} \\
\hline $\begin{array}{l}\text { Dang et al. } \\
(2010)^{65}\end{array}$ & S: $34 \%$, C: $39 \%$ & S:17\%, C:12\% & \multicolumn{2}{|c|}{$\begin{array}{l}60 \% \text { of the exposed asthmatic workers reported that their asthma seemed worse } \\
\text { at work, while none of the non-exposed asthmatic subjects reported this. }\end{array}$} \\
\hline $\begin{array}{l}\text { Renström et al. } \\
(2011)^{74}\end{array}$ & $29 \%$ atopic & $7-22 \%$ asthmatic & \multicolumn{2}{|c|}{$\begin{array}{l}\text { Atopic subjects had a significant higher proportion with symptoms at work (PR } \\
3.2(95 \% \mathrm{Cl} 1.6-6.2), \mathrm{p}<0.001)\end{array}$} \\
\hline $\begin{array}{l}\text { Shiryaeva et al. } \\
(2014)^{77}\end{array}$ & $21.4 \%$ atopic & $7.1 \%$ asthmatic & \multicolumn{2}{|c|}{$\begin{array}{l}\text { There were no significant differences in respiratory outcomes related to exposure } \\
\text { between atopic and non-atopic subjects. }\end{array}$} \\
\hline $\begin{array}{l}\text { Delfino et al. } \\
(2015)^{79}\end{array}$ & - & $100 \%$ asthmatic & \multicolumn{2}{|c|}{$\begin{array}{l}\text { One study among asthmatic school children found that subjects with baseline } \\
\mathrm{FEV}_{1}<80 \% \text { of predicted had significant interactions with endotoxin exposure, } \\
\text { predicted } \mathrm{FEV} \mathrm{V}_{1} \text { values dropped with } 7.7 \%(95 \% \mathrm{Cl}-12.3 \text { to }-3.3 \%) \text { for every } 2.19 \\
\mathrm{EU} / \mathrm{m}^{3} \text { increase in exposure. }\end{array}$} \\
\hline Lai et al. (2015) ${ }^{86}$ & $69 \%$ atopic & $100 \%$ asthmatic & \multicolumn{2}{|c|}{$\begin{array}{l}\text { Airborne endotoxin was associated with increased maximum symptom-days only } \\
\text { in subjects with non-atopic asthma. For atopics, there was an inverted U-shaped }\end{array}$} \\
\hline
\end{tabular}




\begin{tabular}{|l|l|l|l|}
\hline & & $\begin{array}{l}\text { relationship between school air endotoxin and maximum symptom-days (plateau } \\
\left.\text { at } 230 \mathrm{EU} / \mathrm{m}^{3}\right)\end{array}$ \\
\hline
\end{tabular}

* $\mathrm{S}=$ subjects, $\mathrm{C}=$ controls 


\section{Tabel A4.7. Best-evidence synthese}

\begin{tabular}{|c|c|c|}
\hline $\begin{array}{l}\text { Effect of endotoxin } \\
\text { exposure }\end{array}$ & Evidence in included studies & $\begin{array}{l}\text { Evidence } \\
\text { rating }\end{array}$ \\
\hline \multirow[t]{4}{*}{ Wheeze } & $\begin{array}{l}\text { Worse when exposed (sign): } 2 \text { strong (Hoopmann 2006, } \\
\text { Horick 2006), } 1 \text { moderate (Lai 2015) }\end{array}$ & \multirow[t]{4}{*}{$\begin{array}{l}\text { Weak } \\
\text { evidence }\end{array}$} \\
\hline & $\begin{array}{l}\text { Worse when exposed (not sign): } 1 \text { strong (Shiryaeva 2014), } \\
3 \text { moderate (Ramagopal 2014, Bose 2016, Schlünssen 2011) }\end{array}$ & \\
\hline & Better when exposed (sign): - & \\
\hline & Better when exposed (not sign): - & \\
\hline \multirow[t]{4}{*}{ Cough } & Worse when exposed (sign): 1 weak (Heldal 2004) & \multirow{4}{*}{$\begin{array}{l}\text { Insufficient } \\
\text { evidence }\end{array}$} \\
\hline & Worse when exposed (not sign): 1 strong (Shiryaeva 2014) & \\
\hline & Better when exposed (sign): - & \\
\hline & Better when exposed (not sign): 1 strong (Zock 1998) & \\
\hline \multirow[t]{4}{*}{$\begin{array}{l}\text { (Nocturnal) asthma } \\
\text { symptoms }\end{array}$} & $\begin{array}{l}\text { Worse when exposed (sign): } 1 \text { strong (Hoopmann 2006), } 3 \\
\text { moderate (Rabinovitch 2005, Lai 2015, Schlünssen 2011) }\end{array}$ & \multirow[t]{4}{*}{$\begin{array}{l}\text { Weak } \\
\text { evidence }\end{array}$} \\
\hline & $\begin{array}{l}\text { Worse when exposed (not sign): } 2 \text { moderate (Ramagopal } \\
\text { 2014, Bose 2016) }\end{array}$ & \\
\hline & Better when exposed (sign): - & \\
\hline & Better when exposed (not sign): - & \\
\hline \multirow[t]{4}{*}{ FEV $_{1}$} & $\begin{array}{l}\text { Worse when exposed (sign): } 4 \text { strong (Delfino 2015, Zock } \\
\text { 1998, Mandryk 1999, Cyprowski 2015), } 1 \text { moderate } \\
\text { (Rabinovitch 2005) }\end{array}$ & \multirow[t]{4}{*}{$\begin{array}{l}\text { Weak } \\
\text { evidence }\end{array}$} \\
\hline & $\begin{array}{l}\text { Worse when exposed (not sign): } 1 \text { strong (Shiryaeva 2014), } \\
1 \text { moderate (Kawamoto 1987) }\end{array}$ & \\
\hline & Better when exposed (sign): - & \\
\hline & Better when exposed (not sign): - & \\
\hline
\end{tabular}

Consistent findings $=75 \%$ of the findings are significant in one direction, 
Strong evidence $=$ consistent findings in 2 or more high quality studies,

Moderate evidence $=$ consistent findings in 1 high quality study and at least one low quality study; or consistent findings in multiple low quality studies,

$\underline{\text { Weak evidence }}=$ no consistent findings, all studies show results in one direction (at least 2 significant) and no conflicting findings exist,

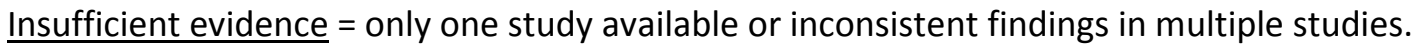




\section{Appendix 5. Analyse associaties endotoxine op woonadres en gezondheidseffecten}

\subsection{Gebruikte vragenlijstgegevens VGO-onderzoek}

Current asthma - A positive answer to at least one of the questions:

$\square$ Have you had an attack of asthma in the last 12 months?

$\square$ Have you been woken by an attack of shortness of breath at any time in the last 12 months?

$\square$ Are you currently taking any medicine (including inhalers, aerosols or tablets) for asthma?

COPD - A positive answer to the following question:

$\square$ Have you ever been told by a doctor that you had chronic obstructive pulmonary disease or emphysema?

Nasal allergies - A positive answer to the following question:

$\square$ Do you have any nasal allergies including 'hay fever'?

Wheeze - A positive answer to the following question:

$\square$ Have you had wheezing or whistling in your chest at any time in the last 12 months?

Wheeze + SOB (= Shortness Of Breath) - A positive answer to the follow-up question:

"Was u kortademig tijdens dit piepen op de borst?"

Wheeze + no cold - A positive answer to the follow-up question:

"Heeft u dit piepen op de borst gehad wanneer u niet verkouden was?"

Usage of inhaled corticosteroids - A positive answer to the following question:

$\square$ n the last 12 months, have you regularly (on most days) taken budesonide, fluticason, beclomethason, ciclesonide or any other corticosteroid inhaler?

Daily cough - A positive answer to the following question:

$\square$ “Hoest u vrijwel dagelijkst, wel drie maanden per jaar? 


\subsection{Fit voor verschillende blootstelling-responsmodellen.}

AIC (Akaike Information Criterion) waarden van splines voor veehouderijen in een buffer van 1000m, model met afstand tot de dichtstbijzijnde veehouderij en model met middels een verspreidingsmodel berekende endotoxineconcentratie.

\begin{tabular}{|c|c|c|c|c|}
\hline \multirow[b]{2}{*}{ Uitkomst } & \multicolumn{2}{|c|}{$\begin{array}{l}\text { In VGO studie gehanteerde } \\
\text { proxies voor blootstelling aan } \\
\text { veegerelateerde emissies }\end{array}$} & \multicolumn{2}{|c|}{$\begin{array}{l}\text { berekende concentraties } \\
\text { verkregen met } \\
\text { verspreidingsmodellen }\end{array}$} \\
\hline & $\begin{array}{l}\text { aantal } \\
\text { veehouderijen in } \\
1000 \mathrm{~m} \text { buffer }\end{array}$ & $\begin{array}{l}\text { afstand tot } \\
\text { dichtst- } \\
\text { bijzijnde } \\
\text { veehouderij }\end{array}$ & PM10 & endotoxine \\
\hline Atopie & 2814.17 & 2806.89 & 2812.25 & 2806.51 \\
\hline Longfunctie: FEV1 & 18603.46 & 18606.68 & 18608.54 & 18606.35 \\
\hline Longfunctie: FVC & 17915.49 & 17917.27 & 17917.18 & 17913.56 \\
\hline Longfunctie: FEV1/FVC & 16052.25 & 16054.16 & 16054.44 & 16055.91 \\
\hline Longfunctie: MMEF & 22003.61 & 22008.46 & 22008.92 & 22010.73 \\
\hline Huidig astma & 8448.52 & 8446.65 & 8441.51 & 8443.41 \\
\hline COPD & 4274.56 & 4269.41 & 4271.52 & 4271.24 \\
\hline Neusallergie & 12739.81 & 12735.19 & 12737.91 & 12735.12 \\
\hline Dagelijks hoesten & 9403.11 & 9404.50 & 9395.54 & 9395.34 \\
\hline Piepen op de borst & 9428.95 & 9432.85 & 9430.92 & 9428.47 \\
\hline $\begin{array}{l}\text { Kortademig tijdens piepen op } \\
\text { de borst }\end{array}$ & 7478.73 & 7488.56 & 7485.25 & 7483.46 \\
\hline $\begin{array}{l}\text { Piepen op de borst zonder } \\
\text { verkoudheid }\end{array}$ & 6767.27 & 6777.36 & 6773.53 & 6769.67 \\
\hline
\end{tabular}

